\title{
Talissa Barroco Harb
}

Análise do desempenho fisiológico e da composição química de Pterocladiella capillacea (Rhodophyta, Gelidiales) submetida a diferentes irradiâncias

Analysis of physiological performance and chemical composition of Pterocladiella capillacea (Rhodophyta, Gelidiales) under different irradiances

São Paulo 2016 


\section{Talissa Barroco Harb}

\section{Versão corrigida}

O original encontra-se disponível no Instituto de Biociências

Análise do desempenho fisiológico e da composição química de Pterocladiella capillacea (Rhodophyta, Gelidiales) submetida a diferentes irradiâncias

Analysis of physiological performance and chemical composition of Pterocladiella capillacea (Rhodophyta, Gelidiales) under different irradiances

Dissertação apresentada ao Instituto de Biociências da Universidade de São Paulo, para a obtenção de Título de Mestre em Ciências Biológicas, na Área de Botânica.

Orientadora: Profa. Dra. Fungyi Chow

São Paulo 


\section{Ficha Catalográfica}

Barroco Harb, Talissa

Análise do desempenho fisiológico e da composição química de Pterocladiella capillacea (Rhodophyta, Gelidiales) submetida a diferentes irradiâncias. 205p.

Dissertação (Mestrado) - Instituto de Biociências da Universidade de São Paulo. Departamento de Botânica.

1. Pterocladiella capillacea 2. Irradiância 3. Fotossíntese

4. Antioxidantes 5. Micosporinas

I. Universidade de São Paulo. Instituto de Biociências. Departamento de Botânica.

\section{Comissão Julgadora:}


Aos meus pais, Sandra e Geraldo, e meus irmãos Marcelo, Victor e Diego (in memoriam) Obrigada por trazerem sentido à minha vida! 
And if we've only got this life in this adventure, oh, then I wanna share it with you!

Adventure of a Lifetime - Coldplay 


\section{Agradecimentos}

Aos meus pais, Sandra Barroco e Geraldo Harb, pelo amor incondicional, incentivo e apoio que me permitiram chegar até aqui. Amo muito vocês!

Aos meus irmãos, Marcelo e Victor Harb, amores que alegram a minha vida, obrigada pelo companheirismo e por estarem sempre presentes. Eu amo vocês!

À minha orientadora, Profa. Fungyi Chow pela oportunidade e por todo entusiasmo, dedicação, amizade, paciência e ensinamentos ao longo dessa jornada. Obrigada por ter confiado em mim!

Ao Paulo Anger, todo o meu carinho e amor. Obrigada pela paciência, compreensão, palavras de incentivo e apoio nas noites de estudo. Te amo!

À Jacqueline Anger, pelo suporte nesta importante etapa da minha vida. Obrigada por ter me recebido tão bem na família.

À Profa. Mutuê Toyota Fujii pela ajuda e disponibilidade em coletar o material estudado.

Às Profas. Nair Sumie Yokoya, Estela Maria Plastino e Mariana Cabral de Oliveira por terem participado do meu exame de qualificação e contribuído com suas sugestões para este trabalho.

À Profa. Déborah dos Santos por ter colaborado com as análises e extrações de micosporinas.

Ao Prof. Flávio Berchez por gentilmente ter me disponibilizado alguns de seus estudos com Pterocladiella capillacea. 
À Profa. Valéria Cassano por todos os ensinamentos durante o meu período como monitora.

À Priscila Torres por toda ajuda e auxílio ao longo do estudo com as micosporinas.

À Mourisa e Aline Cruz pela assistência e injeção das amostras na Fitoquímica.

Aos técnicos, André Nakasato, Rosário Petti e William Oliveira por todo o auxílio ao longo desses dois anos. Sem vocês tudo teria sido mais difícil! Muito obrigada!

À Karoline Magalhães pelas contribuições com as análises moleculares.

Aos LAMigos André Faria, Beatriz Torrano, Bruno Lenhaverde, Cíntia Iha, Carolina Azevedo, Fabiana Marchi, Fábio Nauer, Fernando Sena, Lygia Ayres, Mariana Mungioli, Mário Machado, Nuno Tavares, Talita Vieira, e em especial, Alexandre Souza, Allyson Nardelli, Ana Maria Amorim, Janaína Pires, Luz Karime Polo e Vanessa Urrea por todos os momentos de descontrações, conversas, reuniões, desabafos, desesperos, ajudas e risadas.

À toda minha família e amigos pelo constante incentivo e torcida.

Ao CNPq pela bolsa concedida nos primeiros meses dessa pesquisa.

À Fundação de Amparo à Pesquisa do Estado de São Paulo (FAPESP 2014/09380-3) por ter acreditado no meu projeto e concedido verba para a sua realização.

À Universidade de São Paulo e à todos os funcionários do Instituto de Biociências pela infraestrutura necessária para a concretização desse estudo.

Por fim, à todos que contribuíram direta ou indiretamente com este trabalho. 


\section{Resumo geral}

Harb, T. B. Análise do desempenho fisiológico e da composição química de Pterocladiella capillacea (Rhodophyta, Gelidiales) submetida a diferentes irradiâncias. 2016. 205p. Dissertação (Mestrado) - Programa de Pós-Graduação em Botância. Instituto de Biociências, Universidade de São Paulo, São Paulo.

A luz age influenciando direta e indiretamente aspectos fisiológicos das macroalgas como crescimento, desenvolvimento, reprodução, desempenho fotossintetizante e aclimatação. A radiação fotossinteticamente ativa (PAR) é a faixa de luz visível compreendida entre 400 e $700 \mathrm{~nm}$, usada pelos organismos para execução da fotossíntese. Os costões rochosos estão sujeitos a uma variabilidade de luz, condição que estimula nas macroalgas o desenvolvimento de eficientes estratégias para otimizar a fotossíntese e manter seu crescimento, além de evitar a fotoinibição e o fotodano. O objetivo desta pesquisa foi caracterizar as repostas fisiológicas e composição química de Pterocladiella capillacea (Rhodophyta, Gelidiales) submetida a duas irradiâncias, 60 e $300 \mu \mathrm{mol}$ fótons. $\mathrm{m}^{-2} \cdot \mathrm{s}^{-1}$ ao longo de oito dias. Os parâmetros analisados foram: taxa de crescimento, desempenho fotossintetizante, teor de carbono, hidrogênio e nitrogênio intracelular, conteúdo pigmentar (ficobiliproteínas, clorofila $a$ e carotenoides), proteínas solúveis totais, potencial antioxidante e teor de aminoácidos tipo micosporinas (MAAs). Pterocladiella capillacea mostrou fotossensibilidade frente ao tratamento de maior intensidade luminosa, no entanto não foi evidenciado fotodano, indicando que a espécie possuiu eficientes respostas de tolerância, em especial ao dissipar energia não fotoquímica não regulada. Dessa forma, $P$. capillacea mostrou alta eficiência em fotoaclimatação e necessitou de pouca intensidade luminosa para manutenção de seus processos vitais. Os resultados mostraram que a espécie é fonte natural de antioxidantes e tem potencial para ser utilizada como nutracêutico. Tal fato pode ser melhor explorado, já que o aumento de luz estimulou as defesas antioxidantes da espécie. A irradiância PAR em 300 $\mu \mathrm{mol}$ fótons. $\mathrm{m}^{-2} \cdot \mathrm{s}^{-1}$ propiciou o acúmulo transiente de MAAs em $P$. capillacea, não se observando diferenças qualitativas na espécie ao longo do tempo, nem entre as irradiâncias. Foi identificada apenas o MAA chinorina, indicando que $P$. capillacea é fonte in natura deste composto amplamente utilizado pela indústria. Os resultados deste estudo complementam trabalhos ecofisiológicos prévios e fornecem subsídios a respeito da estratégia de vida de $P$. capillacea frente às mudanças em intensidades luminosa. 


\section{General abstract}

Harb, T. B. Analysis of physiological performance and chemical composition of Pterocladiella capillacea (Rhodophyta, Gelidiales) under different irradiances. 2016. 205p. Dissertação (Mestrado) - Programa de Pós-Graduação em Botância. Instituto de Biociências, Universidade de São Paulo, São Paulo.

The light acts directly and indirectly influencing physiological aspects of macroalgae such as growth, development, reproduction, photosynthetic performance and acclimatization. The photosynthetically active radiation (PAR) is the visible light that range between 400 and 700 $\mathrm{nm}$, used by organisms for photosynthesis process. The rocky shores are under to a variability of light that imposes on macroalgae the development of efficient strategies in order to optimize photosynthesis and maintain the growth, avoiding photoinhibition and photodamage. The main objective of this research was to characterize the physiological responses and chemical composition of Pterocladiella capillacea (Rhodophyta, Gelidiales) submitted to two irradiances, 60 and $300 \mu \mathrm{mol}$ fótons. $\mathrm{m}^{-2} . \mathrm{s}^{-1}$ over eight days. The parameters analyzed were: growth rate, photosynthetic performance, carbon, hydrogen and nitrogen intracellular, pigment content (phycobiliproteins, chlorophyll and carotenoids), total soluble protein, antioxidant potential and Mycosporine-like amino acids (MAAs). Although, $P$. capillacea is a shadow-type of seaweed and not tolerate high irradiance, Pterocladiella capillacea showed photosensitivity against the treatment of higher light intensity, but no photodamage was observed, indicating that the species possessed reset mechanisms of efficient tolerance, especially to dissipate unregulated photochemical energy. Thus, $P$. capillacea showed high efficiency in photoacclimation and required little light intensity to maintain their life processes. The results showed that $P$. capillacea is a natural source of antioxidants and has the potential to be used as a nutraceutical. This can be better exploited, since the increase of light stimulated the antioxidant defenses of the species. Irradiance PAR at $300 \mu \mathrm{mol}$ fótons. $\mathrm{m}^{-2} \cdot \mathrm{s}^{-1}$ provided the MAAs accumulation in $P$. capillacea, there were no qualitative differences in species over time, or between irradiance. It was only identified the MAA chinorina, indicating that $P$. capillacea is a source in nature of this compound widely used by industry. The results of this study complement previous ecophysiological works and provide subsidies regarding $P$. capillacea life's strategy to the changes in light intensities. 


\section{Índice}

1. Síntese geral do contexto científico do tema

1.1. O Filo Rhodophyta: descrição, importância ecológica, econômica e aplicações ...01

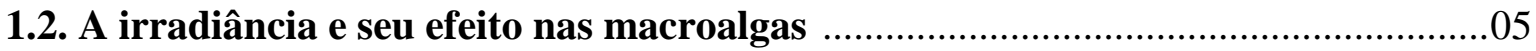

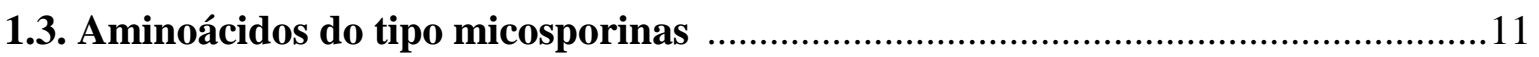

1.4. Pterocladiella capillacea

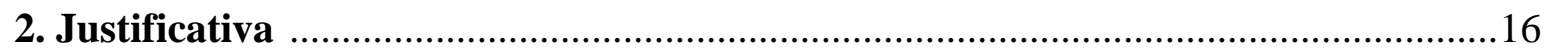

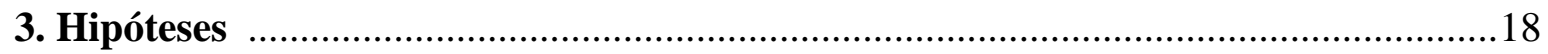

4. Objetivos

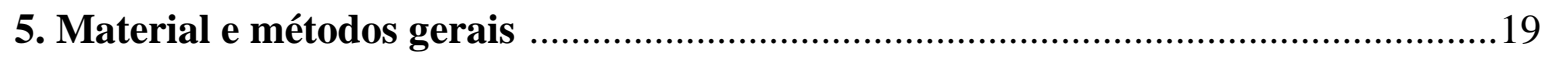

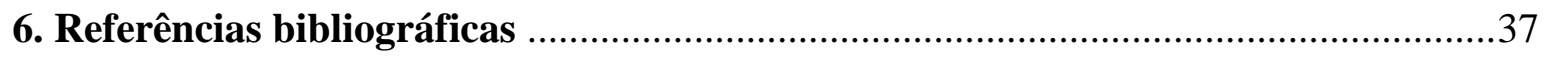

Capítulo I - Fotosensibilidade e desempenho fisiológico de Pterocladiella capillacea (Rhodophyta, Gelidiales): crescimento, fotossíntese, teor de CHN e conteúdo de pigmentos e proteínas

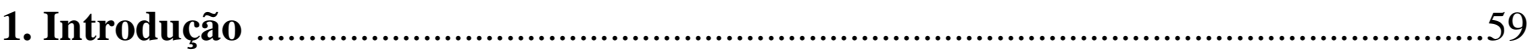

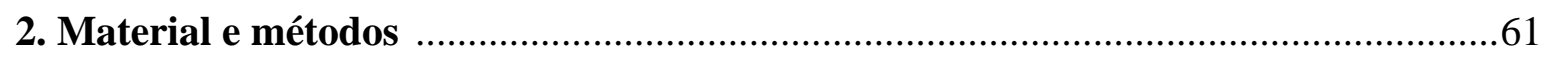

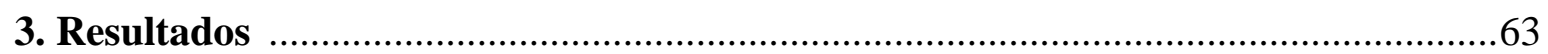

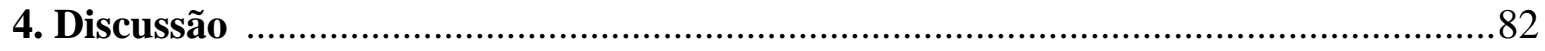

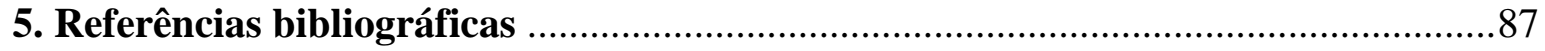


Capítulo II - Variação do potencial antioxidante na alga vermelha Pterocladiella capillacea (Rhodophyta, Gelidiales) submetida à alta irradiância......................................94

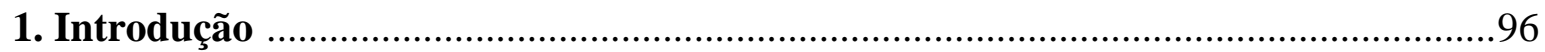

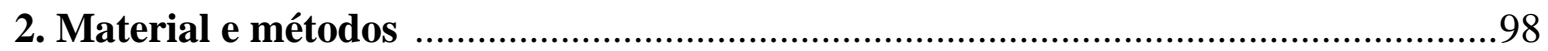

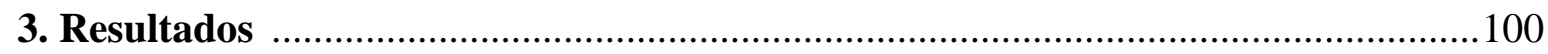

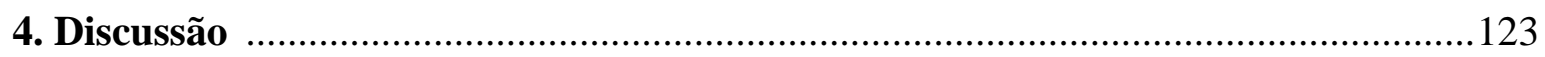

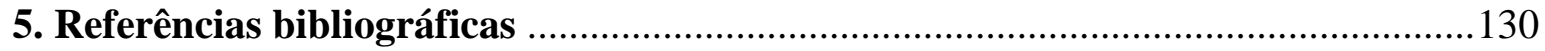

Capítulo III - Composição de aminoácidos tipo micosporinas na alga vermelha Pterocladiella capillacea (Rhodophyta, Gelidiales) e indução por luz ............................135

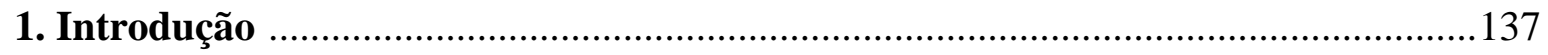

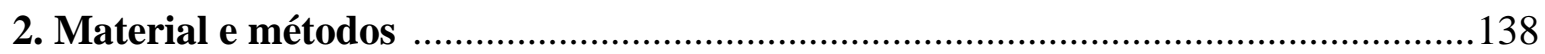

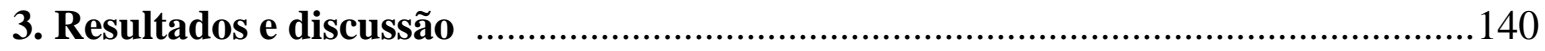

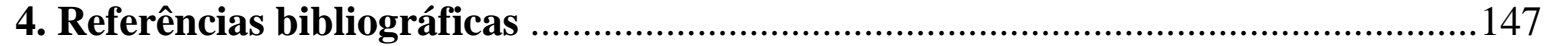

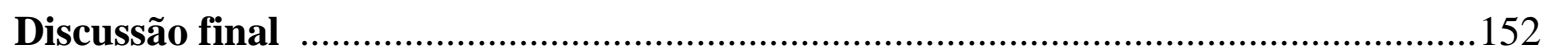

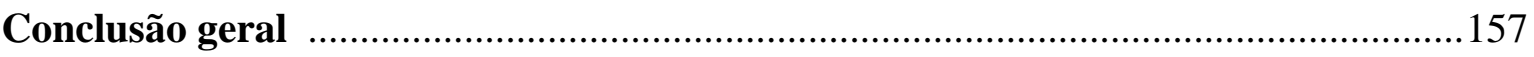

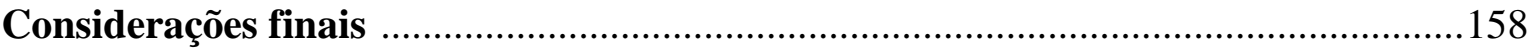

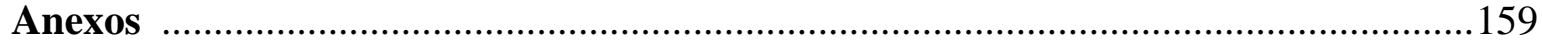




\section{Lista de Figuras}

Figura 1. Mapa climático com a previsão futura de radição solar no Brasil para as décadas de 2020, 2050 e 2080 em dois cenários, altas emissões de $\mathrm{CO}_{2}$ (A2) e baixas emissões de $\mathrm{CO}_{2}$ (B2) comparados com o modelo de climático de referência 1961-1990 (modificado de Hamada et al., 2012) .06

Figura 2. Aspecto geral de Pterocladiella capillacea (S.G. Gmelin) Santelices \& Hommersand. Fonte: Talissa Harb.

Figura 3. Localização do costão rochoso da Praia da Cruz $\left(21^{\circ} 02^{\prime} 01,68\right.$ "S; $\left.40^{\circ} 48^{\prime} 44,43^{\prime \prime} \mathrm{O}\right)$ situada no município de Marataízes, ES

Figura 4. Média de radiação diária no mês de setembro de 2014 e irradiância média no dia de coleta 10/09/2014 (Fonte: CPTEC/INPE)

Figura 5. (A) Costão rochoso da Praia da Cruz e (B) banco de Pterocladiella capillacea em Marataízes - Espírito Santo. Fonte: Talissa Harb

Figura 6. Exsicata de Pterocladiella capillacea depositada no Herbário SPF da Universidade de São Paulo..... .22

Figura 7. Caracteres morfológicos utilizados para a identificação taxonômica de Pterocladiella capillacea. (A) aspecto geral de um índividuo, (B) aspecto geral superficial de estiquídios, (C) vista frontal de célula apical evidenciada, (D) seção transversal do talo.

Figura 8. Árvore filogenética molecular construída pelo método da máxima verossimilhança. A porcentagem da taxa de grupos associados é mostrada ao lado dos ramos da árvore. A árvore foi desenhada em escala, com comprimentos dos ramos medidos com base no número de substituições por sítio. Os dados em negrito respresentam às sequências obtidas pela espécie-alvo no presente estudo.

Figura 9. Taxa de crescimento acumulado de Pterocladiella capillacea ao longo do tempo de experimento nas irradiâncias de 60 e $300 \mu \mathrm{mol}$ fótons. $\mathrm{m}^{-2} \cdot \mathrm{s}^{-1}$. .66

Figura 10. (A) Rendimento quântico ótimo (Fv/Fm), (B) rendimento quântico efetivo (Y(II)) e (C) absorptância de Pterocladiella capillacea ao longo de oito dias de experimento nas irradiâncias de 60 e $300 \mu \mathrm{mol}$ fótons. $\mathrm{m}^{-2} . \mathrm{s}^{-1}$. Os valores representam a média \pm desvio padrão $(n=5)$. Letras distintas indicam diferença significativa $(\mathrm{p}<0,05)$ após a ANOVA bifatorial e teste post-hoc de Newman-Keuls..... 
Figura 11. Dissipação fotoquímica (Y(PSII), dissipação não fotoquímica não regulada (Y(NO)) e dissipação não fotoquímica regulada (Y(NPQ)) de Pterocladiella capillacea ao longo de oito dias de experimento nas irradiâncias de 60 e $300 \mu \mathrm{mol}$ fótons. $\mathrm{m}^{-2} . \mathrm{s}^{-1}$. Os valores representam a média \pm desvio padrão $(n=5)$. Letras distintas indicam diferença significativa $(\mathrm{p}<0,05)$ após a ANOVA bifatorial e teste post-hoc de Newman-Keuls. .68

Figura 12. (A) Saturação luminosa, (B) taxa máxima de transporte de elétrons e (C) eficiência fotossintetizante de Pterocladiella capillacea ao longo de oito dias de experimento nas irradiâncias de 60 e $300 \mu \mathrm{mol}$ fótons. $\mathrm{m}^{-2} . \mathrm{s}^{-1}$. Os valores representam a média \pm desvio padrão $(n=5)$. Letras distintas indicam diferença significativa $(\mathrm{p}<0,05)$ após a ANOVA bifatorial e teste post-hoc de Newman-Keuls

Figura 13. Curvas de ETR x PAR e a respectiva área sob a curva de Pterocladiella capillacea ao longo de oito dias de experimento (t0-t8) nas irradiâncias de (A) $60 \mu \mathrm{mol}$ fótons. $\mathrm{m}^{-2} \cdot \mathrm{s}^{-1}$ e (B) $300 \mu \mathrm{mol}$ fótons. $\mathrm{m}^{-2} \cdot \mathrm{s}^{-1}$. Os valores representam a média \pm desvio padrão $(\mathrm{n}=5)$

Figura 14. Conteúdo pigmentar de Pterocladiella capillacea ao longo de oito dias de experimento nas irradiâncias de $60 \mathrm{e} 300 \mu \mathrm{mol}$ fótons. $\mathrm{m}^{-2} \cdot \mathrm{s}^{-1}$. (A) ficoeritrina, (B) ficocianina, (C) aloficocianina, (D) clorofila $a$ e (E) carotenoides totais. Os valores representam a média \pm desvio padrão $(n=5)$. Letras distintas indicam diferença significativa $(\mathrm{p}<0,05)$ após a ANOVA bifatorial e teste post-hoc de Newman-Keuls.

Figura 15. Conteúdo de proteínas solúveis totais ao longo do tempo de oito dias de experimento nas irradiâncias de 60 e $300 \mu \mathrm{mol}$ fótons. $\mathrm{m}^{-2} . \mathrm{s}^{-1}$. Os valores representam a média \pm desvio padrão $(n=5)$. Letras distintas indicam diferença significativa $(p<0,05)$ após a ANOVA bifatorial e teste post-hoc de Newman-Keuls.

Figura 16. Conteúdo de (A) carbono, (B) hidrogênio e (C) nitrogênio de Pterocladiella capillacea ao longo de oito dias de experimento nas irradiâncias de 60 e $300 \mu \mathrm{mol}$ fótons. $\mathrm{m}^{-2} \cdot \mathrm{s}^{-1}$. Os valores representam a média \pm desvio padrão $(\mathrm{n}=5)$. Letras distintas indicam diferença significativa $(\mathrm{p}<0,05)$ após a ANOVA bifatorial e teste post-hoc de Newman-Keuls. .74

Figura 17. Espectro absorção nos comprimentos de onda do UV dos extratos tamponados de pigmentos de P.capillacea ao longo de oito dias de experimento nas irradiâncias de (A) $60 \mu \mathrm{mol}$ fótons. $\mathrm{m}^{-2} \cdot \mathrm{s}^{-1} \mathrm{e}$ (B) $300 \mu \mathrm{mol}$ fótons. $\mathrm{m}^{-2} \cdot \mathrm{s}^{-1}$. 
Figura 18. Ordenação biplot dos componentes 1 e 2 de $P$. capillacea durante o periodo experimental (t0, t1, t3, t5, t7 e t8) em função das variáveis métricas de ALC (aloficocianina), Área ETR, ETR máx (taxa máxima de transporte de elétrons), Clh (clorofila), FC (ficocianina), FE (ficoeritrina), Fv/Fm (rendimento quântico máximo), Ik (saturação luminosa), PST (proteínas solúveis totais), TC (taxa de crescimento), Y(II) (rendimento quântico efetivo), $\mathrm{Y}(\mathrm{NO})$ (dissipação não fotoquímica não regulada) e Y(PSII) (dissipação fotoquímica) para irradiâncias de 60 e $300 \mu \mathrm{mol}$ fótons. $\mathrm{m}^{-2} \cdot \mathrm{s}^{-1}$. As cores vermelha, marrom e preta indicadas em cada tratamento representam os três agrupamentos.

Figura 19. Dendrograma obtido da análise de agrupamento hierárquico utilizando os tratamentos de Pterocladiella capillacea ao longo do tempo (t0, t1, t3, t5, t7 e t8) para irradiâncias de 60 e $300 \mu \mathrm{mol}$ fótons. $\mathrm{m}^{-2} . \mathrm{s}^{-1}$

Figura 20. Dendrograma obtido da análise de agrupamento hierárquico utilizando as métricas resultantes de Pterocladiella capillacea avaliadas nos diferentes tempos e irradiâncias .....

Figura 21. Porcentagem da atividade antioxidante para o sequestro do radical DPPH em Pterocladiella capillacea ao longo de oito dias de experimento (t0-t8) nas irradiâncias de 60 (A-F) e $300 \mu \mathrm{mol}$ fótons. $\mathrm{m}^{-2} \cdot \mathrm{s}^{-1}(\mathrm{G}-\mathrm{L})$ 101

Figura 22. Sequestro do radical DPPH expressos como EC50 para algas vermelhas. As barras pretas correspodem aos valores de EC50 para os padrões ácido gálico e Trolox. Os valores de Pterocladiella capillacea em 60 e $300 \mu \mathrm{mol}$ fótons. $\mathrm{m}^{-2} \cdot \mathrm{s}^{-1}$ referem-se, respectivamente, ao EC40 e EC20 ao final do experimento (tempo 8) (Modificado de Zubia \& Roblelo, 2007) 103

Figura 23. Porcentagem da atividade antioxidante e valores de EC50 para o radical ABTS em Pterocladiella capillacea ao longo de oito dias de experimento (t0-t8) nas irradiâncias de 60 (A-F) e $300 \mu \mathrm{mol}$ fótons. $\mathrm{m}^{-2} . \mathrm{s}^{-1}$ (G-L) 105

Figura 24. Valores de EC50 para o ensaio da captura do radical ABTS em Pterocladiella capillacea ao longo de oito dias de experimento nas irradiâncias de 60 e $300 \mu \mathrm{mol}$ fótons. $\mathrm{m}^{-2} \cdot \mathrm{s}^{-1}$. As barras cinzas (controle) representam o EC50 da curva padrão de ácido gálico e Trolox para o respectivo ensaio. 106

Figura 25. Porcentagem da atividade antioxidante para quelante de metais em Pterocladiella capillacea ao longo de oito dias de experimento (t0-t8) nas irradiâncias de 60 (A-F) e $300 \mu \mathrm{mol}$ fótons. $\mathrm{m}^{-2} \cdot \mathrm{s}^{-1}(\mathrm{G}-\mathrm{L})$ 107 
Figura 26. Porcentagem da atividade antioxidante e valores de EC50 para o poder redutor do Folin-Ciocalteu em Pterocladiella capillacea ao longo de oito dias de experimento (t0t8) nas irradiâncias de 60 (A-F) e $300 \mu$ mol fótons. $\mathrm{m}^{-2} . \mathrm{s}^{-1}$ (G-L)

Figura 27. Valores de EC50 para o ensaio do poder redutor do Folin-Ciocalteu em Pterocladiella capillacea ao longo de oito dias de experimento nas irradiâncias de 60 e 300 $\mu$ mol fótons. $\mathrm{m}^{-2} \cdot \mathrm{s}^{-1}$. As barras cinzas (controle) representam o EC50 da curva padrão de ácido gálico e Trolox para o respectivo ensaio 110

Figura 28. Porcentagem da atividade antioxidante e valores de EC50 para o FRAP em Pterocladiella capillacea ao longo de oito dias de experimento (t0-t8) nas irradiâncias de 60 (A-F) e $300 \mu \mathrm{mol}$ fótons. $\mathrm{m}^{-2} \cdot \mathrm{s}^{-1}$ (G-L)

Figura 29. Valores de EC50 para o ensaio do FRAP em Pterocladiella capillacea ao longo de oito dias de experimento nas irradiâncias de 60 e $300 \mu \mathrm{mol}$ fótons. $\mathrm{m}^{-2} \cdot \mathrm{s}^{-1}$. As barras cinzas (controle) representam o EC50 da curva padrão de ácido gálico e Trolox para o respectivo ensaio

Figura 30. Porcentagem de atividade antioxidante e equivalente padrão ácido gálico para (A e F) sequestro do radical DPPH, (B e G) captura do radical ABTS, (C e H) atividade quelante de metais, (D e I) poder redutor do Folin-Ciocalteu, (E e J) potencial de redução do ferro (FRAP) em Pterocladiella capillacea ao longo de oito dias de experimento nas irradiâncias de 60 e $300 \mu \mathrm{mol}$ fótons. $\mathrm{m}^{-2} \cdot \mathrm{s}^{-1}$. Os valores representam a média \pm desvio padrão $(\mathrm{n}=5)$. Letras distintas indicam diferença significativa $(\mathrm{p}<0,05)$ após a ANOVA bifatorial e teste post-hoc de Newman-Keuls 116

Figura 31. Porcentagem de atividade antioxidante e equivalente padrão ácido gálico para os extratos tamponados de pigmentos. (A e F) sequestro do radical DPPH, (B e G) captura do radical ABTS, ( $\mathrm{C}$ e $\mathrm{H}$ ) atividade quelante de metais, (D e I) poder redutor do FolinCiocalteu, (E e J) potencial de redução do ferro em (FRAP) Pterocladiella capillacea ao longo de oito dias de experimento nas irradiâncias de 60 e $300 \mu \mathrm{mol}$ fótons. $\mathrm{m}^{-2} \cdot \mathrm{s}^{-1}$. Os valores representam a média \pm desvio padrão $(n=5)$. Letras distintas indicam diferença significativa $(\mathrm{p}<0,05)$ após a ANOVA bifatorial e teste post-hoc de Newman-Keuls ....119

Figura 32. Ordenação biplot dos componentes 1 e 2 de $P$. capillacea durante o periodo experimental ( $\mathrm{t} 0, \mathrm{t} 1, \mathrm{t} 3, \mathrm{t} 5, \mathrm{t} 7$ e t8) em função das variáveis métricas de DPPH, ABTS, Quelante, Folin e FRAP para irradiâncias de 60 e $300 \mu \mathrm{mol}$ fótons. $\mathrm{m}^{-2} \cdot \mathrm{s}^{-1}$. As cores vermelha, marrom e preta indicadas em cada tratamento representam os três agrupamentos 121 
Figura 33. Dendrograma obtido da análise de agrupamento hierárquico utilizando os tratamentos de Pterocladiella capillacea ao longo do tempo (t0, t1, t3, t5, t7 e t8) para irradiâncias de 60 e $300 \mu \mathrm{mol}$ fótons. $\mathrm{m}^{-2} . \mathrm{s}^{-1}$.....

Figura 34. Dendrograma obtido da análise de agrupamento hierárquico utilizando as métricas resultantes de Pterocladiella capillacea avaliadas nos diferentes tempos e irradiâncias .

Figura 35. (A e D) Cromatogramas obtidos por CLAE, (B e E) espectros de absorção em UV/vis e (C e F) estruturas moleculares de porphyra-334 (A-C) e chinorina (D-F) de padrões isolados de Gracilaria domingensis 140

Figura 36. (A) Cromatograma do extrato metanólico de Pterocladiella capillacea submetida a $60 \mu \mathrm{mol}$ fótons. $\mathrm{m}^{-2} \cdot \mathrm{s}^{-1}$, com destaque para um único pico em 8,5 min e a estrutura molecular do MAA identificado (chinorina). (B) Espectro de absorção em UV/vis do pico de chinorina em 334 142

Figura 37. Quantificação da MAA chinorina em Pterocladiella capillacea ao longo do tempo (dias) nas irradiâncias de 60 e $300 \mu \mathrm{mol}$ fótons. $\mathrm{m}^{-2} . \mathrm{s}^{-1}$. Letras diferentes indicam diferença significativa $(\mathrm{p}<0,05)$ após a ANOVA e teste post-hoc de Newman-Keuls ....145

Figura 38. Ordenação biplot dos componentes 1 e 2 de $P$. capillacea durante o periodo experimental ( $\mathrm{t} 0, \mathrm{t} 1, \mathrm{t} 3, \mathrm{t} 5, \mathrm{t} 7$ e t8) em função das variáveis métricas TC (taxa de crescimento), Clh (clorofila $a$ ), FE (ficoeritrina), FC (ficocianina), ALC (aloficocianina), PST (proteínas solúveis totais), Fv/Fm (rendimento quântico ótimo), Y(II) (rendimento quântico efetivo), Y(PSII) (dissipação fotoquímica), Y(NO) (dissipação não fotoquímica não regulada), Área ETR (área de ETR x PAR), Ik (saturação luminosa), ETR máx (taxa máxima de transporte de elétrons), DPPH, ABTS, Quelante, Folin, FRAP, e MAAs (aminoácidos do tipo micosporinas) para irradiâncias de 60 e $300 \mu \mathrm{mol}$ fótons. $\mathrm{m}^{-2}$. $\mathrm{s}^{-1}$. As cores vermelha, marrom e preta indicadas em cada tratamento representam os três agrupamentos .153

Figura 39. Dendrograma obtido da análise de agrupamento hierárquico utilizando os tratamentos de Pterocladiella capillacea ao longo do tempo (t0, t1, t3, t5, t7 e t8) para irradiâncias de 60 e $300 \mu \mathrm{mol}$ fótons. $\mathrm{m}^{-2} . \mathrm{s}^{-1}$

Figura 40. Dendrograma obtido da análise de agrupamento hierárquico utilizando as métricas resultantes de Pterocladiella capillacea avaliadas nos diferentes tempos e irradiâncias . 155 


\section{Lista de Abreviaturas}

AAOX $=$ atividade antioxidante

Abs = absorbância

ABTS = 2,2-azinobis (3-etilbenzotiazolina-6-ácido sulfônico)

Alfa $(\alpha)=$ eficiência fotossintetizante

$\mathrm{ALC}=$ aloficocianina

$\mathrm{BSA}=$ albumina bovina sérica

Car $=$ carotenoides

$\mathrm{CHN}=$ carbono, hidrogênio e nitrogênio intracelular

CLAE = cromatógrafo líquido de alta eficiência

Clh $a=$ clorofila $a$

EC50 = concentração efetiva para reduzir 50\% a atividade

EROS = espécies reativas de oxigênio

$\mathrm{ETR}=$ taxa de transporte de elétrons

$\mathrm{ETR}_{\text {máx }}=$ taxa máxima de transporte de elétrons

DPPH - 2,2-difenil-1-picrilhidrazila

$\mathrm{FC}=$ ficocianina

FCT = conteúdo de substâncias fenólicas totais

$\mathrm{FE}=$ ficoeritrina

Fm = fluorescência máxima em algas aclimatadas ao escuro

Fm’= fluorescência máxima em algas aclimatadas à luz

Fo = fluorescência basal

FRAP = potencial de redução do ferro

$\mathrm{Ft}=$ fluorescência transiente

Fv = fluorescência variável 
Fv/Fm = rendimento quântico ótimo ou máximo

$\mathrm{Ik}=$ saturação luminosa

MAA - aminoácido tipo micosporina

$\mathrm{MF}=$ massa fresca

MS = massa seca

PAR $=$ radiação fotossintéticamente ativa $(400-700 \mathrm{~nm})$

PAM $=$ pulso de amplitude modulada

PSI $=$ fotossistema I

PSII $=$ fotossistema II

$\mathrm{TC}=$ taxa de crescimento

$\mathrm{UV}=$ ultravioleta

VS = solução de enriquecimento de von Stosch

$\mathrm{v} / \mathrm{v}=$ volume/volume

$\mathrm{Y}(\mathrm{II})=$ rendimento quântico efetivo

$\mathrm{Y}(\mathrm{NO})=$ dissipação não fotoquímica não regulada

$\mathrm{Y}(\mathrm{NPQ})=$ dissipação não fotoquímica regulada

$\mathrm{Y}(\mathrm{PSII})=$ dissipação fotoquímica 


\section{Lista de Tabelas}

Tabela 1. Fator de conversão de radiação (McCree, 1981). .20

Tabela 2. Sumário de alguns estudos mostrando parâmetros fotossintetizantes como eficiência quântica $(\alpha)$, dissipação não fotoquímica regulada $\mathrm{Y}(\mathrm{NPQ})$, taxa máxima de transporte de elétrons $\left(\mathrm{ETR}_{\text {máx }}\right)\left(\mu \mathrm{mol}\right.$ elétrons. $\left.\mathrm{m}^{-2} \cdot \mathrm{s}^{-1}\right)$, saturação luminosa $(\mathrm{Ik})(\mu \mathrm{mol}$

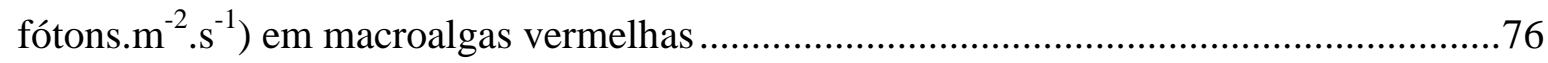

Tabela 3. Influência da irradiância PAR em algas vermelhas quanto à: taxa de crescimento, conteúdo pigmentar (Clh $a$ - clorofila, FE - ficoeritrina, FC - ficocianina, ALC - aloficocianina e Car - carotenoides, expressos em $\mu \mathrm{g} \cdot \mathrm{g}^{-1}$ ), PST - proteínas solúveis totais $\left(\mu \mathrm{g} \cdot \mathrm{g}^{-1}\right)$.

Tabela 4. Relação da concentração dos padrões ácido gálico e Trolox (expressa em massa) para cada um dos ensaios estudados, com sua respectiva equação da reta e coeficiente de regressão $\left(\mathrm{R}^{2}\right)$ 100

Tabela 5. Conteúdo de substâncias fenólicas totais (FCT) em equivalente padrão para ácido gálico em macroalgas 


\section{Lista de Anexos}

ANEXO I - Medidas de fluorescência da clorofila $a$ do PSII 159

ANEXO II - Curvas padrões de BSA para quantificação de proteínas solúveis totais ....171

ANEXO III - Potencial antioxidante de extratos metanólicos de P.capillacea 172

ANEXO IV - Extração de MAAs 195

ANEXO V - Componentes principais e correlação de Pearson. .200 


\section{Síntese geral do contexto científico do tema}

\subsection{O Filo Rhodophyta: descrição, importância ecológica, econômica e aplicações}

O Filo Rhodophyta, ou algas vermelhas, constitui uma linhagem monofilética e um clado com características particulares dentro do Reino Archaeplastida e dentre as macroalgas. Não apresentam centríolo nem formas flageladas no seu histórico de vida, possuem uma composição de pigmentos semelhante ao das cianobactérias, as ficobiliproteínas (aloficocianina, ficocianina e ficoeritrina), que ocorrem na forma de ficobilissomos, tendo tilacoides livres no interior dos cloroplastos envoltos por duas membranas, conhecido como cloroplasto simples, semelhantes às células de cianobactérias, que também apresentam tilacoides livres com ficobilissomos. Acredita-se que uma cianobactéria ancestral, sofreu um processo de endossimbiose por um organismo heterotrófico, dando origem ao plastídeo ancestral deste grupo (Delwich et al., 1995; McFadden, 1999; Rodriguez-Ezpeleta et al., 2005), evento conhecido como endossimbiose primária. Armazenam amido florideano no citoplasma (Yoon et al., 2006; Graham et al., 2009), caracterizado por apresentar propriedades entre o glicogênio e o amido, reagindo com iodo formando uma substância de coloração marrom-avermelhada.

Existem cerca de 6.500 espécies de rodófitas conhecidas atualmente, isso o torna o grupo mais diverso de macroalgas quando comprarado com as algas pardas, 1.750 espécies, e as algas verdes, 1.200 espécies (Kilinç et al., 2013). A maioria das algas vermelhas habita ambientes marinhos bentônicos, sendo predominantes nos mares tropicais e subtropicais, mas existem algumas espécies de água doce e de ambientes polares. Nos ambientes marinhos, as rodófitas ocupam desde a zona superior da região entremarés até grandes profundidades, frequentemente são bentônicas, fixas ao substrato (Vidotti \& Rollemberg, 2004).

As algas vermelhas apresentam três grandes grupos de pigmentos coletores de luz: clorofila $a$, ficobilinas (ou ficobiliproteínas) e carotenoides. A clorofila $a$ cumpre papel principal de máxima absorção de luz para a fotossíntese no centro de reação fotoquímica. As ficobiliproteínas e os carotenoides atuam como pigmentos acessórios, coletando energia em comprimentos de onda no qual a clorofila $a$ não é tão eficiente na sua absorção, permitindo assim uma amplificação na captação de energia que será transferida para o processo de fotossíntese (Garbary \& Gabrielson, 1990; Graham et al., 2009). As ficobiliproteínas estão sempre associadas, formando ficobilissomos, presentes como ficoeritinas, ficocianinas, 
aloficocianinas. As ficoeritrinas são as responsáveis pela principal característica do grupo, a coloração vermelha que na maioria dos representantes de Rhodophyta mascaram a presença de outros pigmentos (Graham et al., 2009; Kilinç et al., 2013). As ficocianinas e aloficocianinas encontram-se em menor quantidade e possuem coloração azulada. Esses pigmentos podem ser utilizados como corantes naturais nas indústrias alimentícia e cosmética (Hold \& Kraan, 2011), assim como marcadores fluorescentes, aplicados em ensaios imunológicos e técnicas de microscopia (Raposo et al., 2013).

Em algas vermelhas, há duas classes de carotenoides presentes: as xantofilas (ex. zeaxantina, luteína, anteraxantina e violaxantina) e os carotenos (principalmente o $\beta$ caroteno). As duas classes de carotenoides diferem na presença da molécula de oxigênio em suas fórmulas moleculares (Pangestuti \& Kim, 2011). As xantofilas são moléculas polares e possuem grupos oxigenados com hidroxilas ou cetonas. Os carotenos são altamente apolares, formados por hidrocarbonetos insaturados. Todos estes compostos demonstram bioatividade de interesse (Sampaio \& Cruz, 2014).

A parede celular deste grupo é constituída por uma parte interna e rígida, formada por microfibrilas de celulose, e outra mais externa, mucilaginosa, formada por polímeros de galactanas, como o ágar e as carragenanas. Alguns grupos de algas vermelhas apresentam deposição de carbonato de cálcio na parede, conferindo grande rigidez ao talo. Tal deposição pode estar na forma de aragonita ou calcita (Lobban \& Harrison, 2000).

As algas vermelhas possuem importantes funções no ambiente marinho, desempenham um papel fundamental na manutenção e no equilíbrio dos ecossistemas marinhos, tornando-se local de refúgio, reprodução e berçário, abrigando o principal alimento de diversos invertebrados, tais como poríferos, cnidários, moluscos, crustáceos, equinodermos, dentre outros (Quirós-Rodrígues et al., 2010). Como produtoras primárias, representam também a base da cadeia alimentar para os herbívoros (Dunton \& Schell, 1987), fixando uma quantidade significativa de dióxido de carbono no meio marinho (Lobban \& Harrison, 2000).

Do ponto de vista econômico, as macroalgas vermelhas são utilizadas em diversas aplicações, tais como nas indústrias alimentícia, cosmética e farmacêutica. Na indústria alimentícia, tornaram-se uma das principais fontes de nutrição por fornecerem uma grande quantidade de fibras, minerais, vitaminas e proteínas (Mamatha et al., 2007; MacArtain et al., 2007; Sekmokienė et al., 2007). Em vários países, especialmente da Ásia, mais de 18 milhões de toneladas de macroalgas foram produzidas a partir de coleta extrativista e aquicultura 
mundial (FAO, 2014). A produção de macroalgas cresceu aproximadamente 25 vezes mais entre os anos de 1970 até 2012, o que resultou em aproximadamente US\$ 6,4 bilhões no último ano referido (FAO, 2014). O interesse pelas algas vermelhas é atribuído em especial aos hidrocoloides ágar e carragenana, pois são fontes de matéria prima para diversos produtos (Bixler \& Porse, 2011). A produção de carragenana da macroalga vermelha Kappaphycus alvarezii Doty (Doty) ex P.C. Silva alcançou 50.000 toneladas no ano de 2011, gerando 527 milhões de dólares (Bixler \& Porse, 2011). No mesmo ano, mais de 18 milhões de toneladas de macroalgas foram produzidas a partir de coleta extrativista e aquicultura mundial (FAO, 2014). Em 2012, os cultivos de Gracilaria Greville renderam mais de 2.000.000 toneladas, totalizando um valor de 600 milhões de dólares (FAO, 2012). Os gêneros das algas vermelhas Porphyra C. Agardh, Gracilaria e Gelidium J.V. Lamouroux e da parda Laminaria J.V. Lamouroux contribuem de maneira expressiva nesta produção, sendo os gêneros mais cultivados para exploração comercial (Moll \& Deikman, 1995; McHugh, 2003).

$\mathrm{O}$ ágar e as carragenanas, genericamente chamados de ficocoloides, são polissacarídeos de alto peso molecular, compostos por polímeros de açúcares. O interesse comercial destes compostos deve-se às suas propriedades físicas em soluções aquosas, onde são formadas substâncias viscosas como os geis (gelatinas). Esses geis podem tornar-se sólidos com o decréscimo da temperatura, sendo que a força do gel aumenta com o aumento da concentração (Furlan et al., 2008). A particularidade do grande interesse comercial pelos ficocoloides deve-se a que nenhum dos atuais coloides sintéticos consegue substituir suas características de gelificação e viscosidade (Furlan et al., 2008).

A espécie de estudo é uma agarófita, dessa forma, iremos detalhar mais as características deste ficocoloide. O ágar é formado por uma família de polissacarídeos, as agaranas, uma mistura complexa de dois componentes: agarose e agaropectina, esta última apresenta baixo poder de gelificação e a agarose é um componente altamente gelificante (Ferrario \& Sar, 1996). Diferentes tipos de polissacarídeos podem estar presentes no ágar da mesma espécie e variam de acordo com a espécie, condições ambientais e forma de extração (McHugh, 2003). Gelidium e Gracilaria são responsáveis pela maior parte da matéria-prima utilizada para a extração de agaranas ou ágar. Polissacarídeos extraídos dessas macroalgas resultam em agaranas de qualidade superior (medido pela resistência do gel). Todas as espécies de Gelidium utilizadas para a extração de agaranas comerciais vêem de recursos naturais, principalmente da França, Indonésia, México, Marrocos, Portugal e Espanha. 
Gelidium possui um crescimento lento, apesar de cultivos em tanques e lagoas serem bem sucedidos, economicamente são inviáveis. No entanto, a empresa Marine BioProducts International lançou produtos de ágar e agarose de alta qualidade e reinvidica que os produtos são derivados de seu proprio cultivo de Gelidium. Presumivelmente, o lucro destes produtos no mercado é suficiente para compensar os altos custos de cultivo. Dessa forma, o mercado de Gelidium e Pterocladiella B. Santelices \& Hommersand, será sempre competitivo, porque fornecem um ágar de melhor qualidade e estão disponíveis somente a partir de recursos naturais limitados (FAO, 2003).

As agaranas são amplamente utilizadas na fabricação de gomas, laxantes e meio de cultura para uso em laboratórios. As carragenanas são utilizadas na fabricação de alimentos como iogurtes, sorvetes, achocolatados, embutidos (ex. salsichas, presuntos), gelatinas e geleias, além de poderem ser utilizadas como emulsificante e estabilizante; sua aplicação substitui o amido e a gordura na preparação de alguns produtos, com a vantagem de não ser calórica, não conter odor, cor e sabor. Além destas, são encontradas inúmeras aplicações das agaranas e carragenanas em indústrias não alimentícias (ex. tintas, têxteis, perfumes) e famacêuticas (ex. produtos anticoagulantes e antiinflamatórios) (Vidotti \& Rollemberg, 2004; Bixler \& Porse, 2011; Ferraces-Casais et al., 2011).

Do ponto de vista de atividade biológica destes ficocoloides, diversas propriedades foram pesquisadas e relatadas na literatura tais como atividade anticoagulante e antitrombótica, antiviral, antitumoral, imunomodulatória, antioxidante e anti-hiperlipêmica (Haijin et al., 2003; Zhou et al., 2004; Buck et al., 2006; Campo et al., 2009; Wijesekara \& Kim, 2011; Prajapati et al., 2014).

Vários polissacarídeos sulfatados isolados de algas vermelhas possuem atividade antiherpética. Pujol et al. (2005) observaram que o polissacarídeo sulfatado xilomanana, isolado de Nothogenia fastigiata (Bory) P.G. Parkinson, inibiu eficientemente a replicação dos vírus do herpes HSV-1 e HSV-2, não tendo sido observada citotoxicidade. Resultados promissores foram registrados por Melo et al. (1997) e Cordeiro et al. (2006), mostrando atividade antifúngica de extratos proteicos de Hypnea musciformis (Wulfen) J.V. Lamouroux. Tais estudos evidenciam a importância e o amplo potencial farmacológico de espécies do Filo Rhodophyta, assim como a importância do estudo da sua composição química e potencial bioativo. 


\subsection{A irradiância e seu efeito nas macroalgas}

A sazonalidade de parâmetros abióticos, tais como radiação, temperatura e nutrientes, dentre outros, determina em grande parte o metabolismo e crescimento de macroalgas marinhas bentônicas. Dentre as diferentes alterações nas condições climáticas, o impacto das variações de irradiância solar na superfície da Terra tem sido debatido por muitos cientistas. Por sua vez, a irradiância, incidência de energia em uma superfície, ou disponibilidade de luz, no seu contexto de quantidade, qualidade e duração, influencia grande parte dos eventos reprodutivos e muitos processos fisiológicos como, por exemplo, a fotossíntese, processo vital para as macroalgas (Lüning, 1990; Lobban \& Harrison, 2000).

No contexto climatológico, Hamada et al. (2012) elaboraram mapas climáticos sobre previsões futuras para o Brasil com variáveis de temperatura, precipitação, umidade relativa e radiação solar nas décadas de 2020, 2050 e 2080 em dois cenários, um cenário com altas emissões de $\mathrm{CO}_{2}$ e outro com baixas emissões de $\mathrm{CO}_{2}$ (Fig. 1). Os autores preveem que haverá aumento da radiação solar no Brasil, tais resultados coincidem com trabalhos de Marengo (2001), Camilloni (2005), Marengo et al. (2007). Assim, o cenário das mudanças climáticas globais vem despertando cada vez mais o interesse da comunidade científica, dos governos e da sociedade contemporânea. Vista a possibilidade de influenciar as características dos bens e serviços ecossistêmicos, em virtude das consequências que o aumento da incidência de radiação solar e da temperatura da superfície terrestre poderão ocasionar ao longo dos próximos anos. No entanto, poucos são os estudos que abordam as consequências destas mudanças sobre macroalgas, provavelmente pelos desafios encontrados para se estabelecer uma relação de causa e efeito (Vianna \& Sanquetta, 2012).

No ambiente marinho, fatores como profundidade, altos níveis de turbidez e nutrientes dissolvidos podem causar uma diminuição tanto na quantidade como na qualidade de luz que alcança as comunidades bentônicas (Monro \& Poore, 2005). A luz age influenciando direta e indiretamente aspectos fisiológicos das macroalgas como crescimento, reprodução (Henley \& Ramus, 1989; Lobban \& Harrison, 2000), desempenho fotossintetizante e aclimatação (Demming et al., 1988; Aguilera et al., 1999; Carnicas et al., 1999; Dawes et al., 1999). 


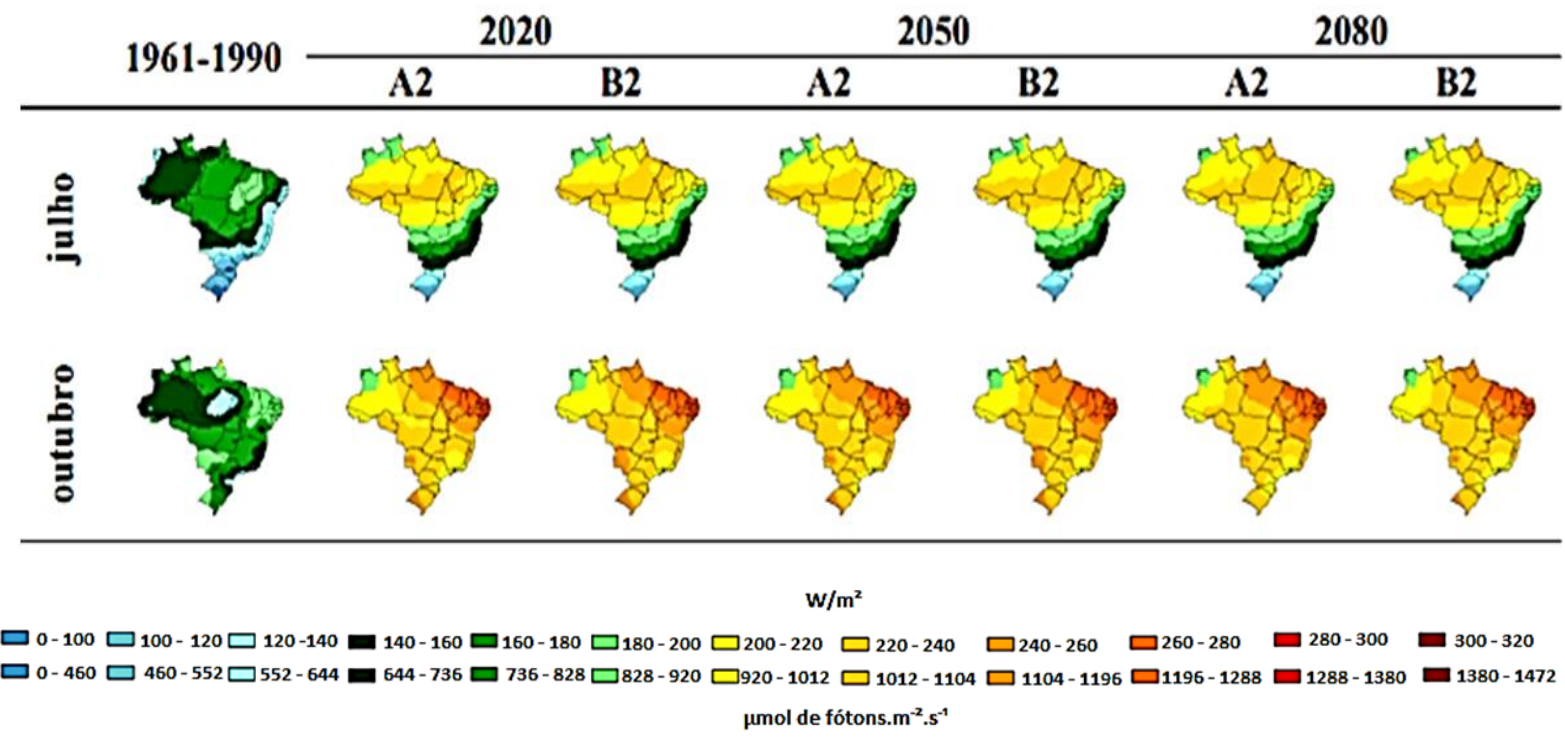

Figura 1. Mapa climático com a previsão futura de radiação solar no Brasil para as décadas de 2020, 2050 e 2080 em dois cenários, altas emissões de $\mathrm{CO}_{2}(\mathrm{~A} 2)$ e baixas emissões de $\mathrm{CO}_{2}$ (B2) comparados com o modelo de climático de referência 1961-1990 (modificado de Hamada et al., 2012).

Os ambientes aquáticos estão sujeitos a uma variabilidade de luz que impõe aos organismos fotossintetizantes, como as macroalgas, o desenvolvimento de estratégias com o objetivo de otimizar a fotossíntese e manter seu crescimento nessas condições (Falkowski, 1980), ao mesmo tempo que precisam evitar a fotoinibição e o fotodano. Dentre as respostas de curto e longo prazo encontram-se o ciclo das xantofilas, o ajuste da concentração de pigmentos fotossintetizantes pelas células (Kirk, 1994) e a alteração do tamanho e número das unidades fotossintetizantes (Falkowski, 1980; Herzig \& Dubinsky, 1992). Essas alterações irão refletir no padrão de absorção e utilização da radiação fotossinteticamente ativa (PAR; do inglês Photosynthetically Active Radiation), compreendida na faixa espectral da luz visível, entre 400 a $700 \mathrm{~nm}$. A PAR é a faixa espectral que ativa as moléculas de clorofila dos organismos fotossintetizantes. Consequentemente, alterações na atividade fotossintetizante, no metabolismo do carbono (Turpin, 1991), nas taxas específicas de crescimento, no volume celular e na composição quali e quantitaviva de compostos como lipídeos, proteínas e carboidratos (Claustre \& Gostan, 1987; Lewitus \& Caron, 1990) podem ocorrer. Ao longo do seu histórico de vida, as algas podem estar expostas a intensidade de PAR superior à energia necessária para os processos fotoquímicos, ocasionando um estresse luminoso (fotoestresse). Dessa forma, estudos que permitam conhecer o desempenho das algas em codições variáveis 
de PAR são fundamentais, pois esta radiação está diretamente associada à produção de biomassa e taxa de crescimento, sendo também um importante parâmetro para estudos ecológicos, onde a radiação solar é tomada como sendo uma variável independente (Gomes, 2006).

Sob alta irradiância, os cloroplastos tornam-se as organelas mais afetadas, pois o complexo de pigmentos dos aparatos fotossintetizantes pode absorver a energia que está em excesso, sobrecarregando o sistema e, assim, ocasionar um desequilíbrio (Yoshida et al., 2011). Essa situação leva ao aumento da produção e acúmulo de substâncias altamente reativas, radicais livres e substâncias não radicalares, derivadas de oxigênio e de nitrogênio, denominadas espécies reativas de oxigênio (EROs) e espécies reativas de nitrogênio (ERNs), respectivamente (Müller et al., 2001). O acúmulo das espécies reativas é altamente prejudicial, pois são molécula instáveis, podendo causar danos irreparáveis ao organismo. Contudo, os organismos fotossintetizantes apresentam diversas respostas fotoprotetoras.

Em algas vermelhas, objeto de estudo deste trabalho, várias respostas frente ao estímulo de luz ainda necessitam serem explicadas e, possivelmente, diferem ao que já é conhecido em plantas terrestres e algas verdes, devido às diferenças no aparato fotossintetizante. Dentre essas respostas, estão as substâncias fenólicas e carotenoides. Ambos componentes apresentam uma alta correlatividade positiva com a intensidade luminosa, indicando possível função antioxidante (Esteban et al., 2009; Tala, 2013).

Os carotenoides podem desempenhar funções distintas no processo fotossintetizante, pois podem ser encontrados nos complexos coletores de luz auxiliando na absorção e transferência de energia, além de atuarem na defesa contra alta irradiância, exercendo o papel de antioxidantes (Torres et al., 2014).

Como visto acima, substânicas fenólicas e carotenoides estão associados a fotoproteção em macroalgas, assim, um dos mecanismos de defesa frente a oxidação desses organimos são diversos mecanisos antioxidativos que, por sua vez, são estimulados frente ao aumento de luz.

Um antioxidante pode ser definido como qualquer substância que atrasa, previne ou remove o dano oxidativo de uma molécula alvo. O interesse pela pesquisa de substâncias com atividade antioxidante surgiu em países orientais, com o objetivo de buscar novos aditivos para alimentos, uma vez que, os antioxidantes utilizados na época como o hidrixianisol butilado (BHA) e o hidroxitolueno butilado (BHT) demonstraram efeitos carcinogênicos, 
além de alterações enzimáticas e lipídicas em animais (Qi et al., 2005). Os estudos com algas despertaram o interesse da comunidade científica por estas poderem ser estocadas por longos períodos, sem haver deterioração oxidativa (Fujimoto \& Kaneda, 1980; Rocha et al., 2007).

Inúmeras atividades biológicas de algas foram relatadas na literatura incluindo as atividades antioxidantes. As macroalgas marinhas podem ser uma importante fonte de substâncias antioxidantes naturais, pois estão submetidas a rápidas variações de intensidade de luz e concentrações de $\mathrm{O}_{2}$ e $\mathrm{CO}_{2}$ e, assim, sua sobrevivência depende de uma resposta eficiente ao estresse oxidativo (Halliwell \& Whiteman, 2004; Halliwell \& Gutteridge, 2006).

Os mecanismos de defesa contra estresse oxidativo refletem o estado da composição química do organismo como indicador do nível de aclimatação sob estresses ambientais, variações de alguns metabólitos como substâncias fenólicas e antioxidantes ocorrem em diferentes porçes do talo (Connan et al., 2006).

Os sistemas antioxidantes de defesa celular podem ser subdivididos em duas classes. Um deles são os sistemas enzimáticos (ex. superóxido dismutase, ascorbato peroxidase, catalase, glutationa peroxidase), onde há participação de enzimas específicas que reduzem o teor de espécies reativas a moléculas menos reativas, mediante sua neutralização. E os sistemas não enzimáticos, na qual moléculas hidrossolúveis (ex. ácido ascórbico, glutationa, aminoácidos do tipo micosporinas - MAAs, substâncias fenólicas) e lipossolúveis (ex. carotenoides e clorofilas) atuam diretamente neutralizando as espécies reativas (Maschek \& Baker, 2008; Schwachtje \& Baldwin, 2008; Tala, 2013).

A atividade antioxidante de algas vermelhas tornou-se objeto de estudo de vários trabalhos. Torres (2012), observou aumento no teor de fenólicos com o aumento das intensidades luminosas em Gracilariopsis tenuifrons (C.J.Bird \& E.C.Oliveira) Fredericq \& Hommersand.

Quando comparada com outras Gelidiales como Gelidium amansii (J.V. Lamouroux) J.V. Lamouroux, Pterocladiella capillacea (S.G. Gmelin) Santelices \& Hommersand apresentou maior capacidade antioxidante indicando maior habilidade em dissipar radicais livres de oxigênio, tais substâncias atuam também como filtros de radiação UVB e, adicionalmente, reduziram a formação de EROs de forma indireta. Além disso, $P$. capillacea foi mais eficiente no processo de detoxificar peróxido de hidrogênio utilizando os sistemas antioxidantes enzimáticos de ascorbato peroxidase e glutationa redutase do que G. amansii (Lee \& Shiu, 2009). 
Estudos evidenciam que a luz influencia os níveis e o metabolismo de fitorreguladores. Ramlov (2010) avaliou a influência de diferentes concentrações de fitorreguladores sob dois níveis de irradiância (50 e $150 \mu \mathrm{mol}$ de fótons. $\mathrm{m}^{-2} \cdot \mathrm{s}^{-1}$ ) em morfos verde e vermelho de Gracilaria domingensis (Kützing) Sonder ex Dickie. A autora verificou que os efeitos estimulatórios dos fitorreguladores ocorreram, em sua maioria, sob altos níveis de irradiância.

Yokoya \& Handro (1996), observaram que na ausência de luz e presença de fitorreguladores, calos de Grateloupia dichotoma J. Agardh não se regeneraram. Por outro lado, Yokoya et al. (2003) verificaram que houve formação de calos em todos os tratamentos com fitorreguladores com a linhagem verde clara de H. musciformis sob baixa irradiância.

Outros estudos também associaram o crescimento de calos em macroalgas à baixas irradiâncias, como os trabalhos de Notoya et al. (1994) com Eckloniopsis radicosa (Kjelmann) Okamura e Kirihara et al. (1997) estudando Sargassum confusum C. Agardh.

A irradiância também pode alterar o crescimento, conteúdo pigmentar e taxas fotossintetizantes nas macroalgas. Gracilaria chorda Holmes apresentou maiores taxas de crescimento em irradiâncias de 60 a $120 \mu \mathrm{mol} \mathrm{de} \mathrm{fótons.} \mathrm{m}^{-2} . \mathrm{s}^{-1}$, e obteve crescimento reduzido com o descréscimo de irradiância $\left(20\right.$ e $40 \mu \mathrm{mol}$ de fótons. $\mathrm{m}^{-2} \cdot \mathrm{s}^{-1}$ ) (Kakita \& Kamishima, 2006). Em contrapartida, a combinação de temperaturas $\left(25\right.$ e $\left.28^{\circ} \mathrm{C}\right)$ e baixos níveis de irradiância $\left(10,25\right.$ e $50 \mu \mathrm{mol}$ de fótons. $\left.\mathrm{m}^{-2} \cdot \mathrm{s}^{-1}\right)$ foram as condições ótimas para o crescimento de plântulas derivadas da germinação de carpósporos de Gracilaria cornea J. Agardh (Orduña-Rojas \& Robledo, 1999).

Os morfos verde e vermelho de $G$. domingensis tiveram suas taxas de crescimento correlacionadas positivamente com o aumento de irradiância entre 20 e $150 \mu \mathrm{mol}$ fótons. $\mathrm{m}^{-2} . \mathrm{s}^{-}$ 1 (Guimarães, 2000). Quanto ao teor de pigmentos, o morfo vermelhos obteve maior concentração de clorofila $a$ e ficoeritrina, por outro lado as taxas fotossintetizantes do morfo verde foi maior nas irradiâncias entre 10 a $2800 \mu \mathrm{mol}$ fótons. $\mathrm{m}^{-2} \cdot \mathrm{s}^{-1}$ (Guimarães, 2000). Ursi (2005) demonstrou que as taxas de crescimento dos morfos de cor de Gracilaria birdiae E.M. Plastino \& E.C. Oliveira coletadas no Ceará e Espírito Santo foram diferentes cultivadas sob irradiâncias de 100 e $200 \mu \mathrm{mol}$ de fótons. $\mathrm{m}^{-2} . \mathrm{s}^{-1}$.

Barufi et al. (2015) testaram os efeitos de diferentes qualidades espectrais de luz sobre a reprodução, crescimento e o teor de pigmentos em G. birdiae. Algas cultivadas sob luz vermelha apresentaram a menor taxa de crescimento. A concentração de ficoeritrina e 
ficocianina aumentou quando as algas foram cultivadas sob luz verde e azul. Os autores concluíram que a combinação de diferentes comprimentos de onda pode permitir uma melhor exploração dos recursos econômicos.

A radiação visível provoca um efeito positivo em ficobiliproteínas, Figueroa et al. (2012) verificaram que o conteúdo desses pigmentos em Hydropuntia cornea (J. Agardh) M.J. Wynne aumentou $90 \%$ em relação aos controles, cultivados em água do mar em condições de radiação PAR e UV.

Sudatti et al. (2011) verificou que a coloração avermelhada de Laurencia dendroidea J. Agardh foi substituída pela esverdeada de acordo com o aumento da irradiância, refletindo um processo de fotoaclimatação.

O conteúdo de proteínas solúveis totais em tetrasporófitos de G. domingensis foi influenciado pela irradiância e disponibilidade de nutrientes, sendo que o maior teor foi observado sob a irradiância de $100 \mu \mathrm{mol}$ de fótons. $\mathrm{m}^{-2} \cdot \mathrm{s}^{-1}$ (Ramlov, 2010).

A posição no costão rochoso influencia o metabolismo das macroalgas. Martínez \& Rico (2008) observaram que as algas acimatadas a altas irradiâncias costumam apresentar um maior conteúdo de carbono e menor teor de nitrogênio, quando comparadas às algas aclimatadas em zonas com baixas irradiâncias.

A alta radiação (PAR e UV) pode ocasionar fotoinibição e causar danos em proteínas, ácidos nucleicos e alteração na organização celular (Karsten et al., 2011; Bischof \& Steinhoff, 2012). Tais alterações podem afetar os cloroplastos, modificando o tamanho, quantidade, organização e número de tilacoides (Schmidt et al., 2009). Navarro et al. (2010) observaram alterações ultra-estruturais em Iridea cordata (Turner) Bory de Saint-Vincent sob efeito de radiação UVB.

Quando cultivada sob PAR e PAR + UVBR Porphyra acanthophora E.C. Oliveira \& Coll teve alterações ultraestruturais e citológicas como aumento da espessura da parede célula com acúmulo de polissacarídeos, aumento na quantidade de carpósporos e ativação de mecanismos de defesa antioxidante (Bouzon et al., 2012).

Os trabalhos relatados aqui mostram uma diversidade de efeitos da irradiância, tanto quanti e qualitativamente, sobre respostas fisiológicas de macroalgas vermelhas, evidenciando a necessidade de estudar sua influência em diversos aspectos fisiológicos, bioquímicos, de defesa, morfológicos e ultraestruturais. 


\subsection{Aminoácidos do tipo micosporinas}

Outros tipos de compostos reportado como responsáveis pela fotoproteção de diversos organismos aquáticos e que merece uma atenção especial são os aminoácidos tipo micosporinas (MAAs), sintetizados pela via do ácido chiquímico. Os MAAs foram inicialmente isolados em fungos e, por isso, receberam esta nomenclatura. São naturalmente encontrados em bactérias, fungos e algas, atuando como mecanismo de defesa, pois são eficientes bloqueadores químicos de radiação UV. Outros organismos marinhos podem adquirir MAAs através de dieta, simbiose ou associações com determinadas bactérias (Carroll \& Shick, 1996; Shick \& Dunlap, 2002). Esses compostos podem atuar não só como substâncias fotoprotetoras com capacidades antioxidantes, mas também como reservatório de nitrogênio frente a condições de estresse (Korbee et al., 2005).

Muitas macroalgas produzem um ou alguns MAAs. Os maiores produtores estão presentes no Filo Rhodophyta, seguido de Phaeophyta e Chlorophyta (Carreto et al., 2005; Sinha et al., 2007; Singh et al., 2008; Yuan et al., 2009).

A concentração e diversidade de MAAs estão relacionadas com as condições ambientais, como tempo de exposição e intensidade de irradiância ou disponibilidade de nutrientes. A própria distribuição geográfica dos organismos pode estimular ou inibir a biossíntese de MAAs. Dessa forma, os indíviduos que estão nas regiões tropicais apresentam maiores concentrações de MAAs, devido ao fato destes organismos estarem frequentemente expostos a radiação UV, quando comparados aos que habitam de regiões polares (Shick \& Dunlap, 2002). Além disso, pode haver também diferença nos conteúdos e variedades de MAAs dentro de uma mesma espécie (Jeffrey et al., 1999).

MAAs têm sido comumente associados à fotoproteção de radiação UV, no entanto, estudos mostram que PAR também influencia o teor de MAAs. Um padrão na síntese de MAAs foi sugerido por Franklin et al. (2001) ao estudar a macroalga vermelha Chondrus crispus Stackhouse. Os autores relatam que a intensidade de PAR estimulou inicialmente a síntese dos MAAs chinorina, seguida de palitina e asterina, e, posteriormente, houve um declínio total de chinorina. Resultados semelhantes foram observados por Carreto et al. (1990) no dinoflagelado Alexandrium excavatum (Braarud) Balech \& Tangen.

Lee \& Shiu (2009) avaliaram as defesas antioxidantes, produção de MAAs e tolerância à radiação UVB nas Gelidiales $P$. capillacea e G. amansii. Sob aumento de radiação UVB, chinorina, porphyra-334 e palitinol puderam ser detectados nas duas algas. 
Entretanto, a concentração total de MAAs foi maior em P. capillacea do que em G. amansii. Porphyra-334 foi o MAAs dominante em P. capillacea. Neste trabalho foram identificados três grupos fisiologicamente diferentes de algas em termos de valores de MAAs: (1) espécies sem capacidade para biossíntese de MAAs; (2) espécies com um teor basal de MAAs que é ajustado em relação a mudanças na radiação ambiental; (3) espécies com elevado teor constante de MAAs, independentemente das condições ambientais. Pterocladiella capillacea foi incluída no grupo 2, enquanto G. amansii foi inclusa no grupo 1.

Navarro (2011) analisou os efeitos da radiação solar UV em duas espécies de importância comercial do Chile, Mazzaella laminarioides (Bory de Saint-Vincent) Fredericq e Porphyra columbina Montagne. A interação de alta radiação UV e elevado teor de nutrientes estimulou a síntese de MAAs nas duas espécies em curto período.

Barufi et al. (2012) avaliaram a fotoproteção de Gracilaria tenuistipitata C.F. Chang \& B.M. Xia contra a radiação UV e diferentes concentrações de nitrogênio, a quantidade de MAAs aumentou oito vezes na presença de radiação UV. O rendimento quântico máximo foi correlacionado com a abundância de MAAs, sob irradiância PAR (260 $\mu \mathrm{mol}$ de fótons. $\left.\mathrm{m}^{-2} \cdot \mathrm{s}^{-1}\right)$ não foram encontradas correlações.

A disponibilidade de nutrientes parece também ser um fator determinante na biossíntese de MAAs. Korbee et al. (2005) registraram que a síntese de MAAs em duas espécies de Porphyra foi estimulada em meio enriquecido de amônia. Litchman et al. (2002) observaram que baixas concentrações de nitrogênio diminuiu a síntese de MAAs em alguns dinoflagelados.

Barufi et al. (2010) verificaram em G.tenuistipitata que o teor de chinorina foi estimulado em elevadas concentrações de nitrato e radiação UV, por outro lado o teor da MAA porphyra-334 diminuiu, o potencial de aclimatação e fotoproteção contra a alta radiação esteve diretamente relacionado com a disponibilidade de nutrientes para G. tenuistipitata.

Hoyer et al. (2002) observaram três padrões de indução em 8 das 18 macroalgas vermelhas analisadas da Antártica: (1) responderam à radiação do amplo espectro; (2) responderam a estímulos PAR + UVA, sem efeito de UVB adicional; e (3) semelhante a segundo grupo, exceto que sob adição de radiação UVB houve diminuição no teor de MAAs. Tais resultados reforçam a hipótese de que a aclimatação fisiológica e adaptação podem desempenhar um papel fundamental na síntese desses compostos (Carignan et al., 2002; Hoyer et al., 2002). 
Kräbs et al. (2004) verificaram que a síntese de asterina-330, palitinol e palitina em C. crispus foi induzida por radiação UVB. Oyamada et al. (2008) verificaram que os MAAS, em especial micosporina-glicina, têm um efeito protetor em células humanas contra a radiação UV.

Sob influência de PAR, alguns autores estudaram a produção de MAAs em macroalgas, dentre eles Groniger et al. (1999) trabalhando com Porphyra umbicallis Kütz; Carreto et al. (2001) e Callone et al. (2006) com dinoflagelados; Cardozo (2007) estudando G. tenuistipitata, Roleda et al. (2012) com Gracilaria vermiculophylla (Ohmi) Papenfuss, Torres (2012); Torres et al. (2015) e Torres et al. (2016) com G. tenuifrons. De forma geral, os autores relatam que o aumento de radiação, tanto PAR quanto UV, estimulam a síntese de MAAs, no entanto a quantidade, bem como a qualidade desses compostos podem variar entre espécies e estão associados à intensidade e duração da radiação.

Algumas aplicações comerciais para os MAAs, têm-se tornado objeto de pesquisa, como protetores solar e fotoestabilizadores de aditivos em plásticos, pinturas e vernizes (Bandaranayake, 1998; Cardozo et al., 2007).

Vários outros estudos analisaram a síntese de MAAs em macroalgas (Yoshida \& Sivalingam, 1969; Sivalingam et al., 1974; Takano et al., 1979; Franklin et al., 2001; Karentz, 2001; Carignan et al., 2002; Hoyer et al., 2002; Kräbs et al., 2002; Korbee et al., 2004; Kräbs et al., 2004; Korbee et al., 2005; Sinha et al., 2007; Figueroa et al., 2010; Torres et al., 2015, Marques, 2015).

Assim, houve avanço no conhecimento a respeito da biossíntese e fotorregulação de MAAs em macroalgas, principalmente quando cultivadas sob radiação UV, no entanto o estímulo de irradiância frente a esses compostos ainda é pouco abordado e merece investigações mais aprofundadas. 


\subsection{Pterocladiella capillacea}

O gênero Pterocladiella (Rhodophyta, Gelidiales) foi descrito por Santelices \& Hommersand (1997) com o proposto de transferir as espécies do gênero Pterocladia J.Agardh baseando-se em diferenças no desenvolvimento do carposporófito. Pterocladiella agrupa atualmente 17 espécies e 20 táxons (Algaebase, 2016), Dentre estas, a espécie escolhida para este trabalho é Pterocladiella capillacea (Fig. 2):

Reino Archaeplastida

Filo Rhodophyta

Classe Florideophyceae

Ordem Gelidiales

Família Pterocladiaceae

Gênero Pterocladiella B. Santelices \& Hommersand

Espécie Pterocladiella capillacea (S.G. Gmelin) Santelices \& Hommersand

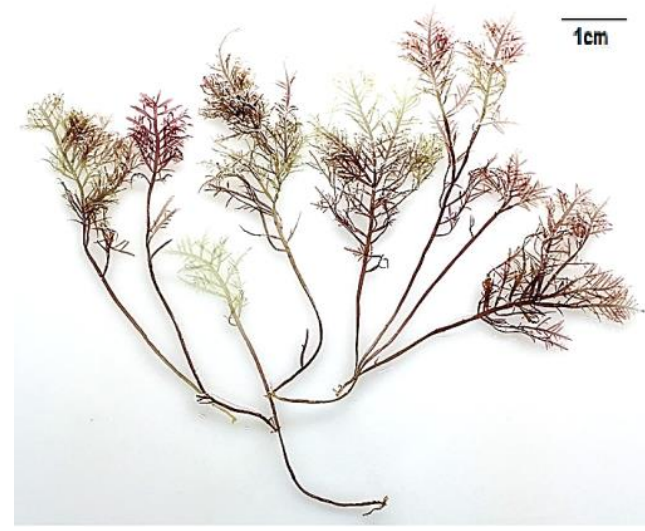

Figura 2. Aspecto geral de Pterocladiella capillacea (S.G. Gmelin) Santelices \&

Hommersand. Fonte: Talissa Harb.

A espécie apresenta relevância ecológica por ser dominante em costões rochosos, formar berçários naturais para muitas espécies, principalmente de invertebrados marinhos como crustáceos, anfípodos, poliquetos, entre outros, além de fornecer refúgio para diversos organismos (Ferreira et al., 2001). Economicamente, é explotada como fonte de alimento e de ágar e agarose, principalmente em países como Coréia e Japão (Santelices, 1998).

Segundo Oliveira \& Berchez (1993) Pterocladiella capillacea já foi explorada no Brasil e no Uruguai, mas a exploração foi interrompida devido ao esgotamento dos bancos 
naturais. Oliveira \& Berchez (1993), tentaram cultivá-la experimentalmente em sistemas de tanques e no mar, porém devido ao lento crescimento não se obtiveram resultados satifatórios. Os melhores resultados foram obtidos de métodos de manejo em bancos naturais onde se retiravam as espécies competidoras, desta forma, abrindo espaço para ocupação de $P$. capillacea. Os autores observaram que a remoção de ouriços do mar aumentou a cobertura de P.capillacea em 20-50\%. Também foi observado que a alga parda Sargassum vulgare C.Agardh era o principal concorrente para o espaço no costão rochoso, a remoção desta macroalga aumentou em $80 \%$ a cobertura de $P$. capillacea. Tais resultados indicam que P. capillacea possui pontencial de exploração no Brasil.

A taxonomia do gênero é bastante discutida, uma vez que há sobreposição de características morfológicas entre os táxons, gerando dificuldades na identificação (Boo et al., 2010). Pterocladiella, eventualmente, é confundido com Gelidium e Pterocladia, sendo a análise de cistocarpos maduros a principal característica morfológica empregada na distinção (Santelices, 1998).

Ferramentas moleculares vêm sendo adotadas em estudos de sistemática do grupo, evidenciando que os três táxons, apesar das semelhanças, são bem definidos geneticamente (Boo et al., 2010). Apesar dessas discussões, é possível identificar P. capillacea em campo pelo seu tamanho, pois costuma ser maior que as outras Gelidiales, além de ter um talo mais rígido, apresentar ramificação claramente pinada e por formar bancos fortemente fixados nos costões rochosos, habitando principalmente fendas protegidas de incidência luminosa e locais batidos (Iha, 2014).

Pterocladiella capillacea é uma das espécies mais estudadas de Gelidiales no Brasil, devido à grande importância ecológica e econômica para consumo humano e extração de ágar de ótima qualidade (Oliveira et al., 1996). Internacionalmente foram realiados estudos envolvendo aspectos da biologia e ecologia (Felicini \& Arrigoni, 1967; Oliveira \& Sazima, 1973; Felicini \& Perrone, 1972; Berchez, 1985; Felicini, 1992), crescimento in vitro, reprodução e extração de ágar (Stewart, 1983; Friedlander \& Zelikovitch, 1984; Berchez \& Oliveira, 1990; Oliveira \& Berchez, 1993; Hommersand \& Fredericq, 1996; Oliveira et al., 1996; Gal-Or \& Israel, 2004; Bottalico et al., 2008), estudos taxonômicos (Ugadim, 1985; Iha, 2014), desempenho fotossintetizante (Coutinho \& Yoneshigue, 1988), produção primária (Kinoshita \& Texeira, 1979), polissacarídeos (Errea \& Matulewicz, 1994; Errea \& Matulewicz, 1996; Errea \& Matulewicz, 2003), morfologia e conteúdo pigmentar (Calabrese 
\& Felicini, 1970; Felicini, 1970; Tripodi, 1971; Felicini \& Perrone, 1986; Felicini et al., 2002; Scrosati, 2002; Talarico et al., 2014), limitação de luz e defesa química (Apelhans et al., 2010), metais pesados (Felix et al., 2014), efeitos da radiação UVB na fisiologia (Schmidt et al., 2015), produção de antioxidantes (Lee \& Shiu, 2009), tolerância à salinidade (Yokoya \& Oliveira, 1992), bioatividade (Abou Zeid et al., 2014; El Kassas \& Attia, 2014; Machado et al., 2015; Alencar et al., 2016), entre outros.

A espécie é amplamente encontrada no litoral brasileiro, desde o estado do Espírito Santo até o litoral do Rio Grande do Sul. Também foram reportadas ocorrências para litoral nordeste, no Ceará e Rio grande do Norte. (Joly, 1957; Taylor, 1960; Joly, 1965; Ugadim, 1985; Fernandes \& Guimarães 1998; Guimarães, 2006; Iha, 2014). No entanto, Jamas (2015) realizou um estudo sobre a diversidade de Gelidiales no Brasil e concluiu que a espécie não é encontrada no nordeste. Segundo Iha (2014), referências para o litoral do nordeste devem ter sido identificações equivocadas e provavelmente podem ser atribuídas à espécie que até então era identificada como Gelidium coarctatum Kützing, já que esta é uma espécie abundante nessa região e possui hábito semelhante à Pterocladiella capillacea.

Sendo P. capillacea uma espécie importante do ponto de vista ecológico e econômico, abordagens fisio-químicos que integrem diferentes aspectos de aclimatação, sensibilidade e tolerância e mecanismos de defesa tornam-se interessante conhecimentos a serem elucidados frente a condições de elevada luminosidade.

\section{Justificativa}

O local de procedência do modelo biológico escolhido neste estudo, litoral do Estado de Espírito Santo, foi propositalmente selecionado devido ao fato da diversidade de espécies de macroalgas no local ser considerada uma das mais altas do Brasil e a grande diversidade de habitats marinhos. Esse cenário, possivelmente, é em virtude dos efeitos combinados da posição geográfica, condições oceanográficas e climáticas, principalmente, na região sul desse estado (Guimarães, 2003; Guimarães, 2006). Essa região é considerada como transicional, pois está entre a costa tropical e subtropical brasileira (Horta et al., 2001). Estudos sobre taxonomia e abundância de macroalgas foram realizados em todo o Estado do Espírito Santo e, especificamente, na região da Baía do Espírito Santo. No entanto, Barbosa et al. (2008) afirmam que trabalhos de cunho ecológico no Espírito Santo são escassos. As características 
de abundância e a presença de ressurgência na região poderiam possibilitar características ecológicas, biológicas e químicas particulares dentre as espécies, o que torna esses organismos modelos interessantes na compreensão dos mecanismos de tolerância frente a condições de alta luminosidade.

Assim, esta pesquisa pretende contribuir de forma significativa para o conhecimento da fisiologia e composição química de $P$. capillacea presente no litoral do município de Marataízes, sul do estado do Espírito Santo, frente à intensidade luminosa. Os resultados do presente trabalho irão complementar estudos ecológicos e fisiológicos prévios e desta forma ampliar o conhecimento a respeito da estratégia de vida de $P$. capillacea frente ao aumento de irradiância. O entendimento destes processos pode ser melhor aproveitado no manejo e na explotação sustentável da espécie.

O presente projeto de mestrado foi parte do Auxílio à Pesquisa Biota/Fapesp No. 2013/50731-1 intitulado "Biodiversidade fisiológica e química de macroalgas ecológica e economicamente importantes". 


\section{Hipóteses}

As hipóteses que norteiam este estudo são:

(a) a fotossíntese e o teor de pigmentos fotossintetizantes irão diminuir na presença de alta intensidade de PAR. Em sendo essa situação corroborada, essa resposta poderia ser interpretada como uma forma de fotoproteção, a fim de evitar a absorção de excesso de energia;

(b) o aumento da intensidade de PAR irá estimular os mecanismos de fotoproteção de potencial antioxidante e MAAs.

\section{Objetivos}

\section{Objetivo geral}

Contribuir para o conhecimento sobre a biologia de algas vermelhas submetidas a duas intensidades de luz mediante a caracterização das respostas fisiológicas e composição química de $P$. capillacea sob influência de alta intensidade de PAR.

\section{Objetivos específicos}

1. Avaliar a sensibilidade e os mecanismos de tolerância de $P$. capillacea submetida a diferentes intensidades de PAR mediante estudos de taxa de crescimento, desempenho fotossintetizante, conteúdo pigmentar (ficobiliproteínas, clorofila $a$ e carotenoides), proteínas solúveis totais e conteúdos de carbono, hidrogênio e nitrogênio;

2. Analisar a variação do potencial antioxidante de $P$. capillacea submetida intensidade elevada de PAR e relacioná-los como possíveis mecanismos de fotoproteção frente a estresse luminoso;

3. Identificar e quantificar os aminoácidos do tipo micosporinas (MAAs) de $P$. capillacea e estudar suas alterações quali e quantitativa após exposição a diferentes intensidades de PAR. 


\section{Material e métodos gerais}

\subsection{Características do local de estudo e dados climáticos da região}

Marataízes localiza-se no litoral sul do estado do Espírito Santo, no Brasil (Fig. 3). Faz divisa com Itapemirim e Presidente Kennedy, o litoral é banhado pelo Oceano Atlântico. Segundo o censo 2010 do Instituto Brasileiro de Geografia e Estatística (IBGE, 2010), é o maior município em população no litoral sul do estado do ES, com cerca de 34.140 habitantes. A região está localizada a cerca de $110 \mathrm{~km}$ da capital Vitória.

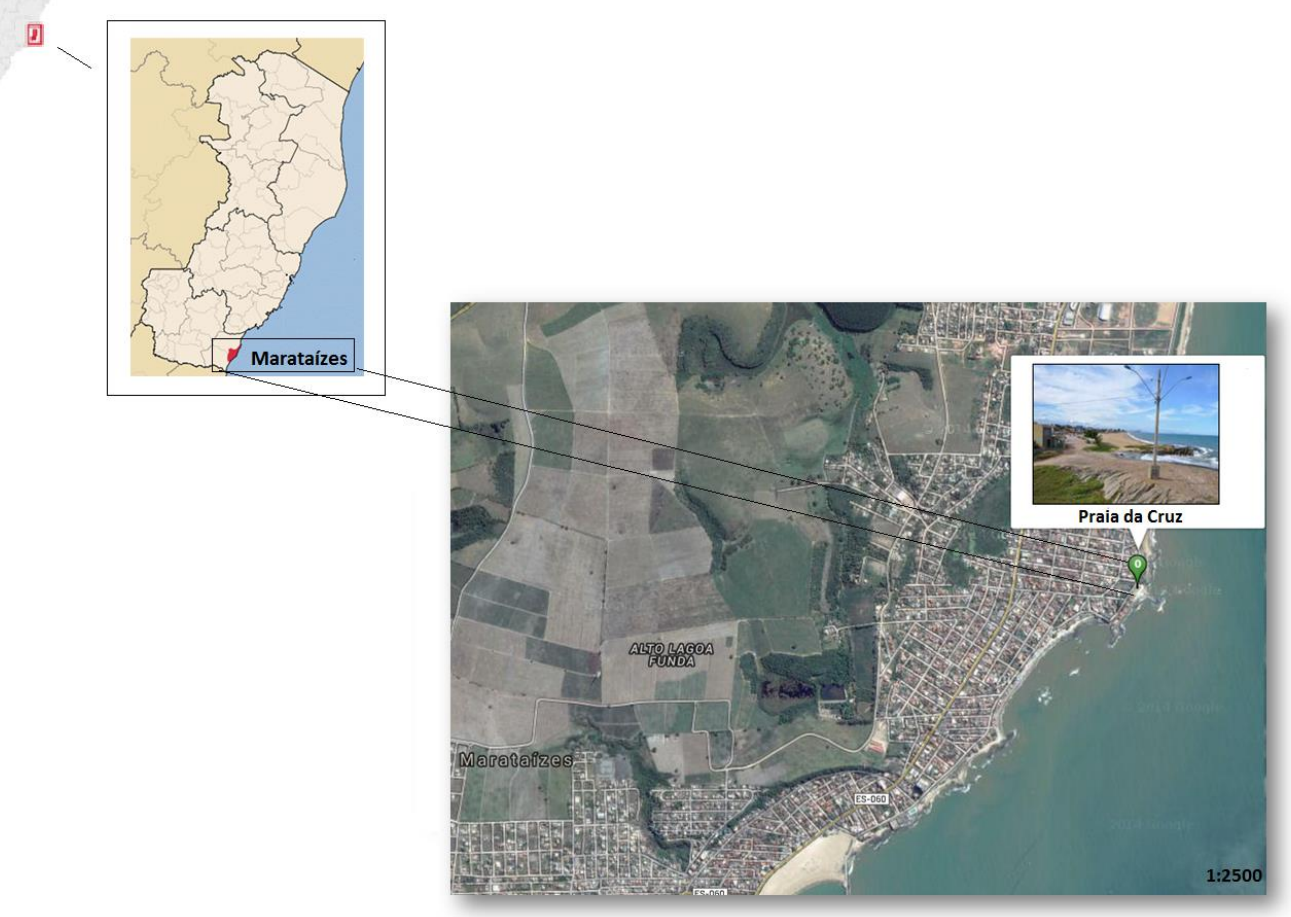

Figura 3. Localização do costão rochoso da Praia da Cruz $\left(21^{\circ} 02^{\prime} 01,68\right.$ "S; 4048'44,43"O) situada no município de Marataízes, ES.

Marataízes situa-se em uma zona caracterizada por intensas chuvas tropicais durante o verão, seguido de um prolongado período de seca do outono ao inverno. No entanto, precipitações frontais associadas à passagem de massas polares podem ser registradas com certa frequência durante o período de estiagem, entre os meses de março e agosto (Albino, 1999). A coleta foi realizada no dia 10 de setembro de 2014, a Figura 4 ilustra os dados de radição em $\mathrm{W} / \mathrm{m}^{2}$ e $\mu \mathrm{mol}$ fótons. $\mathrm{m}^{-2} \cdot \mathrm{s}^{-1}$ obtidos do CPTEC/INPE para o mês de 
setembro/2014 e irradiância para o dia de coleta. É possível observar no Espírito Santo uma radiação média de $1.000 \mu \mathrm{mol}$ fótons. $\mathrm{m}^{-2} \cdot \mathrm{s}^{-1}$ durante o mês de setembro e irradiância média no dia da coleta de aproximadamente $500 \mu \mathrm{mol}$ fótons. $\mathrm{m}^{-2} \cdot \mathrm{s}^{-1}$. A Tabela 1 apresenta os fatores de conversão de radiação segundo McCree (1981).

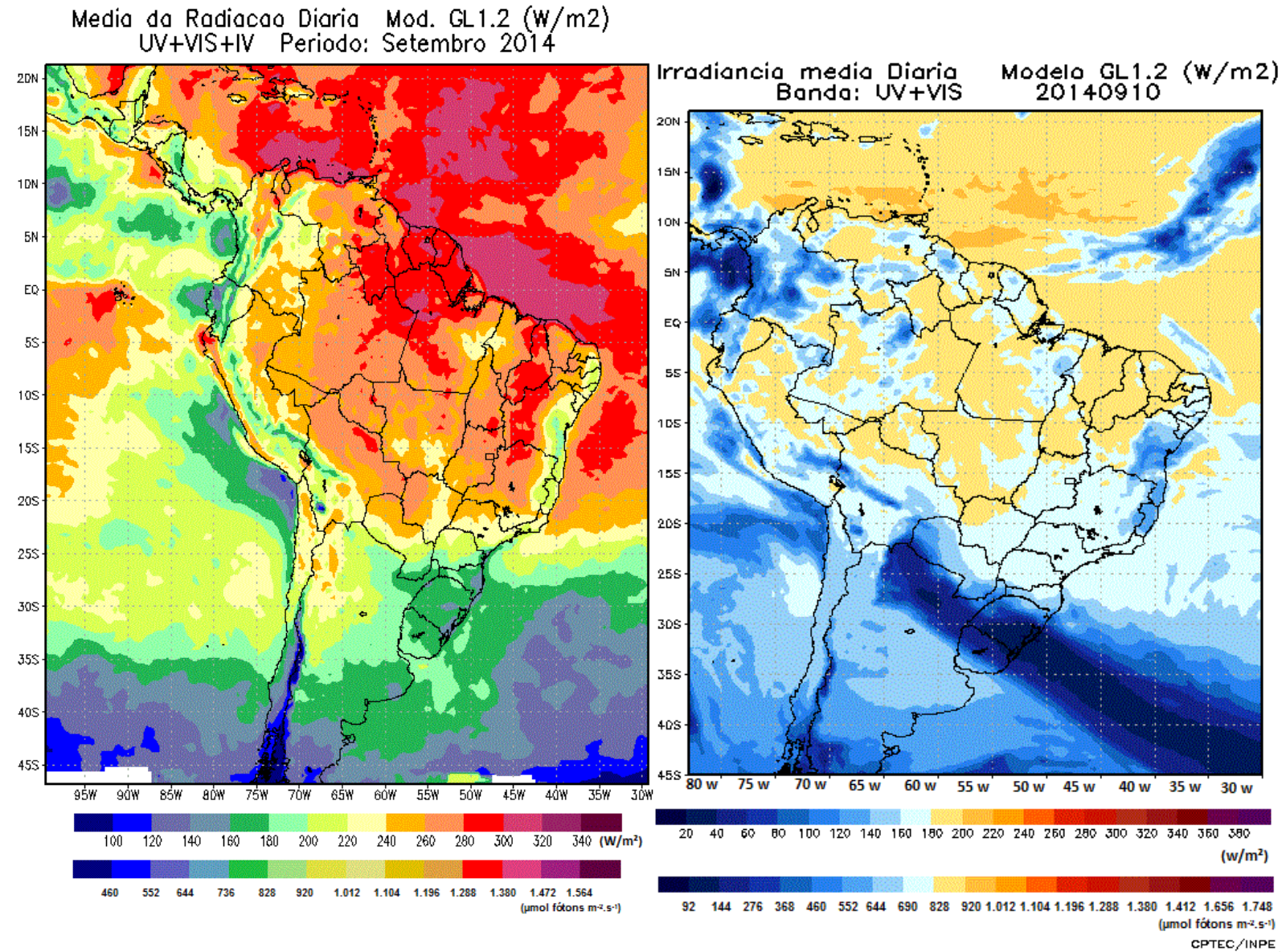

Figura 4. Média de radiação diária no mês de setembro de 2014 e irradiância média no dia de coleta 10/09/2014 (Fonte: CPTEC/INPE).

Tabela 1. Fator de conversão de radiação (McCree, 1981).

\begin{tabular}{ccc}
\hline & Irradiância & \\
\hline De & Para & Conversão \\
$\mu$ mol fótons. $\mathrm{m}^{-2} \cdot \mathrm{s}^{-1}$ & Watts $/ \mathrm{m}^{2}$ & $\div 4,6$ \\
Watts $/ \mathrm{m}^{2}$ & $\mu$ mol fótons. $\mathrm{m}^{-2} \cdot \mathrm{s}^{-1}$ & $\mathrm{x} 4,6$
\end{tabular}


De acordo com a Diretoria de Hidrografia e Navegação (2005), a maré na região é classificada como um regime de micro-maré (menor que $2 \mathrm{~m}$ ), tendo amplitude máxima de 1,4 e 1,5 metros. A temperatura média anual da região é de $22^{\circ} \mathrm{C}$, a média das máximas é registrada entre 28 e $30^{\circ} \mathrm{C}$, enquanto as mínimas permanecem por volta de $15^{\circ} \mathrm{C}$ (Albino, 1999).

Dentre as praiais do litoral do ES, a praia da Cruz foi escolhida por ser um local de fácil acesso, além de possuir a maior abundância da espécie-alvo do presente estudo.

\subsection{Coleta do material biológico, aclimatação em laboratório e delineamento experimental}

A coleta foi realizada em 10 de setembro de 2014 na região entremarés do costão rochoso da praia da Cruz $\left(21^{\circ} 02^{\prime} 01,68^{\prime \prime S}\right.$; 4048'44,43"O) (Fig. 5), localizado no município de Marataízes situado no litoral do estado do Espírito Santo, Brasil pela Profa. Mutuê Toyota Fujii. Amostras de P. capillacea foram coletadas sistematicamente atentando para indivíduos sadios e transportadas para o Laboratório de Algas Marinhas "Édison José de Paula" (LAM) do Instituto de Biociencias da Universidade de São Paulo (IB-USP) em sacos plásticos dentro de uma caixa de isopor. No laboratório, os espécimes foram triados, limpos de macroepífitos e cuidadosamente pincelados para retirada de microepífitos e lavados com abundante água do mar filtrada. Oito fertéis indivíduos foram fixados em formol 4\% (v/v, diluído em água do mar) para verificação taxonômica por caracteres morfológicos e confeção de exsicatas (Fig. 6) que foram depositados no Herbário SPF do IB-USP, Seção Ficologia (número de registro: 57890). Porções dos indivíduos $(\mathrm{n}=4)$ foram acondicionadas em sílica gel para posterior corroboração taxonômica por métodos de biologia molecular. O restante da biomassa foi cultiva em laboratório sob condições controladas para aclimatação e posteriores experimentos. 

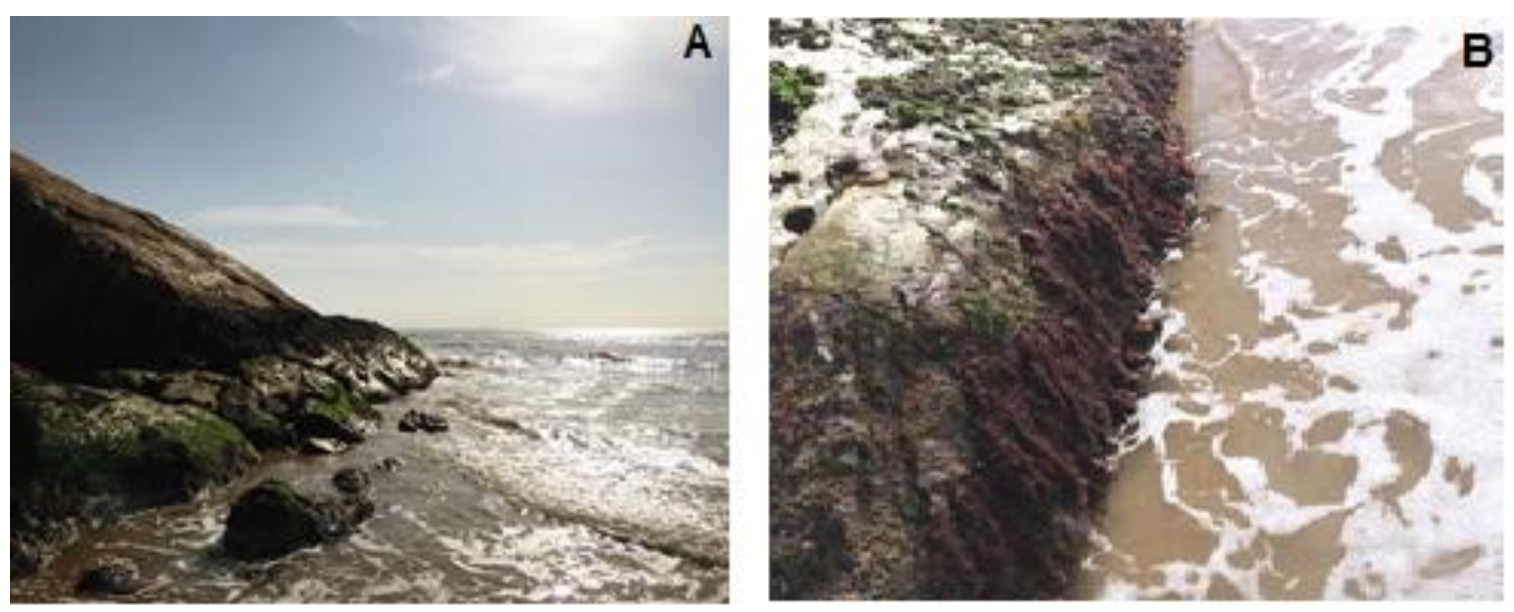

Figura 5. (A) Costão rochoso da Praia da Cruz e (B) banco de Pterocladiella capillacea em Marataízes - Espírito Santo. Fonte: Talissa Harb

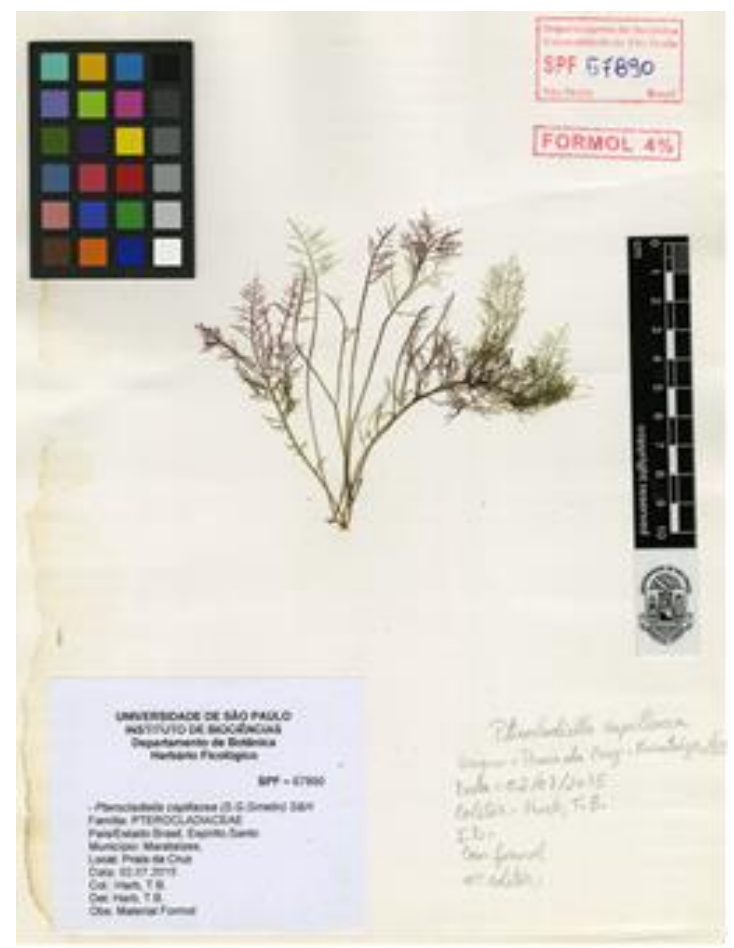

Figura 6. Exsicata de Pterocladiella capillacea depositada no Herbário SPF da Universidade de São Paulo.

O material foi aclimatado por uma semana em condições controladas de laboratório com água do mar (salinidade 32 ups) previamente esterilizada e enriquecida com solução de enriquecimento de von Stosch (VS; Ursi \& Plastino (2001) modificado de Edwards (1970)), na concentração de $100 \%$, em uma proporção de $3 \mathrm{~g}$ de massa fresca (MF) por $1 \mathrm{~L}$ de meio de 
cultivo, sob temperatura de $25 \pm 1^{\circ} \mathrm{C}$, fotoperíodo de 14 h e 10 h de escuro, irradiância de 60 $\pm 5 \mu \mathrm{mol}$ fótons. $\mathrm{m}^{-2} . \mathrm{s}^{-1}$ e aeração intermitente de 30:30 min (ligado:desligado).

A água do mar utilizada foi coletada em frente ao Centro de Biologia Marinha da USP (CEBIMAR) no Município de São Sebastião, SP, tendo salinidade média de 32 ups, e foi esterilizada por meio de dupla filtragem em filtro de pressão (Cuno), com porosidade de 5 e 1 $\mu \mathrm{m}$, e radiação ionizante (Lâmpada UV-C, sistema QUIMIS Q884-21 - 3,8 L/min) (Petti \& Plastino, 2012).

A irradiância foi fornecida por lâmpadas fluorescentes (Philips, modelo luz do dia, $5200 \mathrm{~K} / 40 \mathrm{~W}$ ), periodicamente mensurada com medidor de quanta LI-COR modelo LI-250 (EUA) e sensor esférico LI-COR modelo LI-1000 (EUA). A aeração foi fornecida em períodos alternandos de $30 \mathrm{~min}$ (ligado/desligado) por um compressor radial IBRAM CR03 de diafragma, isento de óleo, sendo inicialmente borbulhado em um frasco contendo água destilada que serve como filtro e umidificador.

Após o período de aclimatação, porções distais entre 8 a $10 \mathrm{~cm}$ de comprimento foram submetidas às mesmas condições descritas acima durante oito dias (período experimental), exceto na proporção experimental de biomassa/volume de meio de cultura que foi utilizado 1 g MF por $1 \mathrm{~L}$ de meio de cultivo e na condição experimental de irradiância $(n=5)$ : (a) $60 \pm 5$ $\mu \mathrm{mol}$ fótons. $\mathrm{m}^{-2} \cdot \mathrm{s}^{-1}$ (controle) e (b) $300 \pm 5 \mu \mathrm{mol}$ fótons. $\mathrm{m}^{-2} \cdot \mathrm{s}^{-1}$. Estudos anteriores do nosso grupo de pesquisa avaliaram a influência das irradiâncias 60,600 e $1000 \mu \mathrm{mol}$ fótons. $\mathrm{m}^{-2} \cdot \mathrm{s}^{-1}$ em macroalgas vermelhas (Torres, 2012; Serra, 2013). A partir dos resultados desses estudos, foi observado que $60 \mu \mathrm{mol}$ fótons. $\mathrm{m}^{-2} \cdot \mathrm{s}^{-1}$ é uma irradiância que propicia bom crescimento de macroalgas vermelhas com baixo comprometimendo do metabolismo das algas, portanto, considerada como não estressante. Dessa forma foi escolhida com irradiância controle no presente estudo. Adicionalmente, nesses estudos foram observados que tratamentos equivalentes e acima de $600 \mu \mathrm{mol}$ fótons. $\mathrm{m}^{-2} \cdot \mathrm{s}^{-1}$ provocaram diversas alterações nas macroalgas, incluindo comprometimento no desempenho fotossintetizante, conteúdo pigmentar, na produção de antioxidantes e na taxa de crescimento, podendo ser consideradas como condições estressantes. O intuito de escolher $300 \mu \mathrm{mol}$ fótons. $\mathrm{m}^{-2} . \mathrm{s}^{-1}$ teve por objetivo estudar uma condição que não comprometesse significativamente o metabolismo geral e avaliar a possível indução de certos processos metabólicos. 
A adição de meio de cultura foi realizada antes de iniciar o experimento (tempo zero) e após uma semana do experimento, este último com o objetivo de avaliar a capacidade de recuperação após suprimento de nutrientes.

Todos os parâmetros avaliados (taxa de crescimento, desempenho fotossintetizante, conteúdo pigmentar, teor de proteínas solúveis, teor de carbono, hidrogênio e nitrogênio, potencial antioxidante e MAAs) foram avaliados nos dias 0 (inicial), 1, 3, 5, 7 e 8. Para cada uma das irradiâncias (60 e 300) e cada um dos tempos experimentais (seis tempos) foram cultivados cinco repetições em frascos separados, considerando-as como cinco repetições independentes e evitando assim a dependência temporal das amostras. No total, o experimento foi constituído por 60 frascos.

As amostras para análises químicas (conteúdo pigmentar e proteínas solúveis, potencial antioxidante, teor de carbono, hidrogênio e nitrogênio e MAAs) foram pesadas em balança analítica Salter-And modelo ER-60A (Japão) de acordo com a massa de material necessária para cada protocolo, congeladas em nitrogênio líquido e armazenadas em ultrafreezer $\left(-80^{\circ} \mathrm{C}\right)$ para posteriores análises.

\subsection{Taxa de crescimento}

O crescimento foi avaliado mediante a pesagem da massa fresca e as taxas de crescimento (TC) foram calculadas segundo a fórmula descrita por Penniman et al. (1986):

$$
\mathrm{TC}=\left[(\mathrm{Mf} / \mathrm{Mi})^{1 / \mathrm{t}}-1\right] \times 100 \%
$$

onde, $\mathrm{Mf}=$ massa fresca final, $\mathrm{Mi}=$ massa fresca inicial, $\mathrm{t}=$ tempo em dias. $\mathrm{O}$ resultado foi expresso em $\% \cdot$ dia $^{-1}$.

\subsection{Desempenho fotossintetizante}

A fotossíntese foi avaliada mediante análises do desempenho fotossintetizante medindo a fluorescência in vivo da clorofila $a$ do PSII (fotossistema II), utilizando um fluorômetro de pulso de amplitude modulada PAM-2500 (Walz, Alemanha). O rendimento quântico máximo $(\mathrm{Fv} / \mathrm{Fm}=(\mathrm{Fm}-\mathrm{Fo}) / \mathrm{Fm})$ foi avaliado em amostra pré-aclimatadas ao escuro por 15 min e calculado segundo Schreiber et al. (1986). O rendimento quântico efetivo [Y(II) $\left.=\left(\mathrm{Fm}^{\prime}-\mathrm{Fo}^{\prime}\right) / \mathrm{Fm}^{\prime}\right]$ foi medido em algas aclimatadas à luz e calculado seguindo Schreiber \& Neubaer (1990).

Fo: Fluorescência no estado de repouso. 
Fm: Fluorescência máxima obtida após a incidência de um pulso saturante de luz em amostras adaptadas no escuro. Centros de reação fechados.

Fm': Fluorescência máxima obtida após a incidência de um pulso saturante de luz em amostras aclimatadas à luz. Centros de reação abertos.

Fv: Flourescência variável; Fm-Fo.

Ft: Fluorescência transiente.

A taxa de transporte de elétrons (ETR) foi estimada mediante curvas P-I (fotossínteseirradiância) sob oito intensidades crescentes de radiação fotossinteticamente ativa (PAR: 0, 24, 61, 108, 186, 456, 752 e $1.024 \mu \mathrm{mol}$ fótons. $\left.\mathrm{m}^{-2} . \mathrm{s}^{-1}\right)$ e calculado como ETR $=$ Y(II) x PAR x A x 0,15. A corresponde à absorptância dos talos (Mercado et al. 1996), de acordo com a fórmula $A=1-I F / I o$, sendo Io a irradiância inicial que incide por uma fonte de luz fixa e IF a irradiância final transmitida através do material algáceo (Ramus \& Rosenberg, 1980). O fator 0,15 representa a fração de clorofila $a$ associada ao PSII para algas vermelhas (Grzymski et al., 1997; Figueroa et al., 2003). Para determinação de absorptância, porções dos talos das algas foram cortados em porções aleatórias de até $3 \mathrm{~cm}$ de comprimento e posicionado na superfície de sensor esférico LI-COR modelo LI-1000 (EUA) conectado a um medidor de quanta LI-COR modelo LI-250 (EUA), a fim de cobrir sua superfície. Em seguida, foi medida a irradiância de luz incidente, sem alga, emitida por uma lâmpada Phillips "luz do dia", com o sensor descoberto, a determinada distância da lâmpada, obtendo o valor Io (irradiância inicial). Três medidas foram feitas com o sensor do medidor de quanta no mesmo ponto fixo. Em seguida, com o sensor mantido no mesmo local, com o auxílio de uma pinça, os talos de algas foram posicionados sobre o sensor, de modo a medir o valor IF (irradiância final), que se refere à irradiância transmitida através dos talos e detectada pelo aparelho medidor. Os valores de IF foram obtidos para as cinco réplicas de cada tratamento. A partir das curvas de ETR-PAR (P-I) foram determinados taxa máxima de transporte de elétrons $\left(E R_{\text {máx }}\right)$ em intensidade de PAR de saturação, eficiência fotossintetizante $(\alpha$, alfa) e intensidade de saturação luminosa (Ik) (Maxwell \& Johnson, 2000), segundo o ajuste de Jassby \& Platt (1976).

Foram avaliados também os parâmetros dissipação fotoquímica (energia utilizada para fotossíntese) $\left[\mathrm{Y}(\mathrm{PSII})=(\mathrm{Fm}\right.$ '-Ft $\left.) / \mathrm{Fm}^{\prime}\right]$, dissipação não fotoquímica não regulada (liberação por calor sem gasto de energia) $[\mathrm{Y}(\mathrm{NO})=\mathrm{F} / \mathrm{Fm}]$ e dissipação não fotoquímica regulada 
(liberação por calor com gasto de energia) $\left[\mathrm{Y}(\mathrm{NPQ})=(\mathrm{F} / \mathrm{Fm})^{\prime}\right) / \mathrm{Fm}$ '] $($ Rohácek, 2002), a fim de distinguir as vias de dissipação da energia absorvida.

Prévio ao início do experimento, a fim de padronizar os parâmetros do procedimento de medidas da fluorescência da clorofila $a$, alguns testes foram realizados com $P$. capillacea coletada no munícipio de Itanhaém, SP, no costão rochoso da praia de Cibratel (3413'19”'S; 47¹5'28,11”O). As padronizações incluíram: a) avaliação dos níveis de pulso de saturação; b) tempo de adaptação ao escuro e pulsos de luz actínica da curva ETR-PAR; c) irradiância versus distância da fibra óptica (ver detalhes em Anexo I).

\subsection{Teor de carbono, hidrogênio e nitrogênio ( $\mathrm{CHN})$}

A quantificação dos elementos carbono, hidrogênio e nitrogênio $(\mathrm{CHN})$ foi realizada na Central Analítica do Instituto de Química da USP, com o uso de um analisador de composição elementar CNH Perkin- Elmer, modelo 2400 (EUA). Amostras de cada tratamento $(\mathrm{n}=5 ; 200 \mathrm{mg} \mathrm{MF})$ foram secas em estufa a $40^{\circ} \mathrm{C}$ até peso constante e trituradas até a obtenção de um pó fino. Alíquotas de 2-3 mg de massa seca (MS) foram carbonizadas a $1.000^{\circ} \mathrm{C}$ em presença de oxigênio puro, desencadeando a completa oxidação da matéria presente nas amostras. Todo o carbono presente nas amostras foi convertido em $\mathrm{CO}_{2}$, o hidrogênio em $\mathrm{H}_{2} \mathrm{O}$ e o nitrogênio em $\mathrm{N}_{2}$. A mistura resultante foi direcionada para uma coluna cromatográfica, onde os componentes foram separados e, então, detectados através de mudanças na condutividade térmica dos produtos. $\mathrm{O}$ conteúdo total de $\mathrm{C}, \mathrm{H}$ e $\mathrm{N}$ das amostras foi calculado de acordo com o percentual de cada elemento e padronizados pela massa seca da alga. Os resultados foram expressos em mg.g $\mathrm{MS}^{-1}$.

\subsection{Conteúdo pigmentar e proteínas solúveis totais}

Amostras de $70 \mathrm{mg}$ MF de cada tratamento $(\mathrm{n}=5)$ foram trituradas em nitrogênio líquido até a obtenção de um pó fino, protegendo o material da incidência de luz que possa oxidar os pigmentos. $\mathrm{O}$ material foi extraído em $1 \mathrm{~mL}$ de tampão fosfato $0,05 \mathrm{M}$ gelado (pH $5,5)$ e centrifugado por $20 \mathrm{~min}$ a $4^{\circ} \mathrm{C}$ e $20.550 \mathrm{rpm}$. O sobrenadante foi analisado tanto no seu conteúdo de ficobilinas e teor de proteínas solúveis totais.

A análise do teor de ficobiliproteínas foi baseado em Kursar et al. (1983), com modificações de Wanderley (2009) e realizado em espectrofotômetro de microplacas UVvisível (Epoch Biotek, EUA), registrando-se as absorbâncias no intervalo de 400 a $700 \mathrm{~nm}$. 
Os valores de concentração ( $\mu \mathrm{g} . \mathrm{g} \mathrm{MF}^{-1}$ ) de cada uma das ficobiliproteínas, padronizados pela massa fresca, foram calculados a partir de suas absorbâncias e com base nas fórmulas descritas em Kursar et al. (1983):

$$
\begin{gathered}
\text { Ficoeritrina }\left(\mu \mathrm{g} \cdot \mathrm{g} \mathrm{MF}^{-1}\right)=\left(155,8 \times \mathrm{A}_{498}\right)-\left(40 \times \mathrm{A}_{614}\right)-\left(10,5 \times \mathrm{A}_{652}\right) \\
\text { Ficocianina }\left(\mu \mathrm{g} \cdot \mathrm{g} \mathrm{MF}^{-1}\right)=\left(151,1 \times \mathrm{A}_{614}\right)-\left(99,1 \times \mathrm{A}_{652}\right) \\
\text { Aloficocianina }\left(\mu \mathrm{g} \cdot \mathrm{g} \mathrm{MF}^{-1}\right)=\left(181,3 \times \mathrm{A}_{652}\right)-\left(22,3 \times \mathrm{A}_{614}\right)
\end{gathered}
$$

onde A corresponde à absorbância no respectivo comprimento assinalado.

A partir de uma alíquota do sobrenadante obtido na descrição acima, o conteúdo de proteínas solúveis totais foi analisado segundo o método espectrofotométrico de Bradford (1976), registrando-se a absorbância a 595 nm em espectrofotômetro de microplacas UVvisível (Epoch Biotek, EUA), utilizando solução para ensaio proteico Bio-Rad (USA) e soro de albumina de bovino (BSA) como padrão para a curva (ver detalhes em Anexo II). Os resultados foram expressos em $\mu \mathrm{g} \cdot \mathrm{g} \mathrm{MF}^{-1}$.

As análises dos carotenoides e da clorofila $a$ seguiram o método descrito por Wanderley (2009). O material sedimentado obtido após a extração das ficobiliproteínas e proteínas solúveis foi ressuspendido em $1 \mathrm{~mL}$ de metanol e extraído por $3 \mathrm{~h}$ a $4^{\circ} \mathrm{C}$ e protegido da luz. Posteriormente, este foi centrifugado por $15 \mathrm{~min}$ a $14.000 \mathrm{~g} \mathrm{e} 4^{\circ} \mathrm{C}$ e o sobrenadante foi analisado em espectrofotômetro de microplacas UV-visível (Epoch Biotek, EUA) registrandose as absorbâncias no intervalo de 400 a $700 \mathrm{~nm}$. Os valores de concentração ( $\mu$ g.g $\mathrm{MF}^{-1}$ ) de clorofila $a$ e carotenoides, padronizados pela massa fresca, foram calculados a partir de suas absorbâncias e com base nas fórmulas modificadas de Lichtenthaler \& Buschmann (2001):

$$
\text { Clorofila } a\left(\mu \mathrm{g} . \mathrm{g} \mathrm{MF}^{-1}\right)=12,61 \times \mathrm{A}_{664}
$$

Carotenoides totais $\left(\mu \mathrm{g} . \mathrm{g} \mathrm{MF} \mathrm{MF}^{-1}\right)=(1000 \times \mathrm{x} 470-1,63 \times$ Clorofila $a) / 221$

onde A corresponde à absorbância no respectivo comprimento assinalado.

Adicionalmente foi realizado uma varredura espectrofotométrica com os extratos tamponados e metanólicos de pigmentos, a fim de analisar os espectros de absorção de cada extrato nos comprimentos de onda do ultravioleta (240 a $400 \mathrm{~nm}$ ). A metodologia foi realizada com volume de $3 \mu \mathrm{L}$ de amostra e lidas em espectrofotômetro NanoDrop UVvisível (Epoch Biotek, EUA). 


\subsection{Potencial antioxidante}

O potencial antioxidante foi determinado a partir de amostras de $200 \mathrm{mg}$ MF trituradas em nitrogênio líquido e extraídas em $1 \mathrm{~mL}$ de metanol por $3 \mathrm{~h}$ em temperatura ambiente e protegido da luz. Seguido de centrifugação a $14.000 \mathrm{rpm}$ por $15 \mathrm{~min}$ a temperatura ambiente. Este extrato foi denominado de extrato bruto de amostra para ensaio antioxidante. As análises foram avaliadas em espectrofotômetro UV-visível para microplacas (Epoch Biotek, EUA) mediante cinco diferentes ensaios: a) atividade sequestradora do radical DPPH (2,2-difenil-1picrilhidrazil), b) captura do radical livre ABTS (2,2-azinobis (3-etilbenzotiazolina-6-ácido sulfônico)), c) potencial de quelar metais de ferro, d) capacidade redutora do Folin-Ciocalteu e) poder de redução do ferro (FRAP, do inglês Ferric Reducing Antioxidant Power). Cada um dos ensaios de potencial antioxidante foi avaliado em seis concentrações de extrato bruto, sendo elas $0,6,8,10,12$ e $13,3 \mathrm{mg} \cdot \mathrm{mL}^{-1}$ segundo o descrito a seguir.

Adicionalmente, foram realizados ensaios antioxidantes para os extratos tamponados e metanólicos de pigmentos nas concentrações de 4,6 mg. $\mathrm{mL}^{-1}$ e $3,1 \mathrm{mg} \cdot \mathrm{mL}^{-1}$, respectivamente.

Os padrões comerciais utilizados como referências foram ácido gálico (Sigma-Aldrich, Brasil) e Trolox (Sigma-Aldrich, Brasil). O ácido gálico é solúvel em água e pertence à classe dos taninos hidrolisáveis (Rezende, 2013). O Trolox é um composto hidrossolúvel e análogo ao $\alpha$-tocoferol (forma mais ativa da vitamin E). Por serem substâncias puras com comprovada ação antioxidante, são amplamente utilizadas na literatura como substâncias referências ou controles positivos para ensaios de atividade antioxidante (Tadolini et al., 2000; Cos et al., 2003). Os dados foram expressos por porcentagem de atividade antioxidante, equivalente padrão e EC50 (concentração efetiva do extrato para reduzir em 50\% a atividade antioxidante máxima) mediante curvas de dose-resposta (ver detalhes em anexo III) com auxílio do programa GraphPad Prism v. 6.01, utilizando um modelo de ajuste sigmoidal de doseresposta (Chen et al., 2013).

\subsubsection{Atividade sequestradora do radical DPPH}

A medida da atividade sequestradora do radical DPPH dos extratos foi realizada de acordo com Pires et al. (em preparação), modificado do método de Brand-Williams et al. (1995). O método é baseado na captura do radical DPPH por antioxidantes, produzindo um descréscimo na absorbância a $517 \mathrm{~nm}$. No ensaio ocorre uma reação de oxi-redução, onde o 
radical DPPH, que apresenta coloração violeta, é reduzido, tornando a reação amarelada e ocorrendo a formação de DPPH-H, reduzido e estável.

Para o ensaio de DPPH foi preparada a solução reativa de DPPH (Sigma-Aldrich, Brasil) em metanol em concentração de $32 \mu \mathrm{g} \cdot \mathrm{mL}^{-1}$ e homogeneizada em ultrassom. A mistura de reação foi preparada com $280 \mu \mathrm{L}$ da solução reativa de DPPH $+20 \mu \mathrm{L}$ de extrato bruto de amostra e incubada por 30 min a temperatura ambiente e protegida da luz, sendo preparados diversos brancos para calibragem (branco de amostra e branco de metanol), além do respectivo controle DPPH. Após a reação, as leituras de absorbância foram feitas no comprimento de onda de $517 \mathrm{~nm}$.

A porcentagem de sequestro do radical DPPH (\% AAOX; atividade antioxidante) foi calculadade acordo com a seguinte fórmula:

$$
\% \text { AAOX DPPH }=\left[\left(\mathrm{Abs}_{\mathrm{DPPH}}-\mathrm{Abs}_{\mathrm{Amostra}}\right) / \mathrm{Abs}_{\mathrm{DPPH}}\right] \times 100
$$

onde: $\mathrm{Abs}_{\mathrm{DPPH}}=$ absorbância do controle DPPH (descontada a absorbância do branco metanol); $\mathrm{Abs}_{\text {Amostra }}=$ absorbância da amostra com a solução reativa de DPPH (descontada a absorbância do branco amostra sem a solução reativa de DPPH).

A atividade antioxidante foi também expressa através de equivalente padrão de ácido gálico e Trolox ( $\mathrm{mg}$ eq. padrão.g $\mathrm{MF}^{-1}$ ). A curva de ácido gálico foi construída em concentrações de 0 a $3 \mu \mathrm{g} \cdot \mathrm{mL}^{-1}$ que correspondem a massas de 0 a $0,9 \mu \mathrm{g}$, com a equação da reta $\mathrm{y}=-0,9499 \mathrm{x}+1,1891\left(\mathrm{R}^{2}=0,98\right)$. Para a curva padrão de Trolox utilizou-se concentrações de 0 a $10 \mu \mathrm{g} \cdot \mathrm{mL}^{-1}$ que correspondem a massas de 0 a $3 \mu \mathrm{g}$, com a equação da reta $y=-0,2473 x+1,1649\left(R^{2}=0,98\right)$.

Os extratos procedentes da extração de pigmentos (extrato tamponado e extrato metanólico) também foram analisados na atividade sequestradora do radical DPPH. Os cálculos de equivalente padrão com os extratos de pigmentos foram realizados com base nas curvas padrões de ácido gálico em concentrações de 0 a $3 \mu \mathrm{g} \cdot \mathrm{mL}^{-1}$ que correspondem às massas de 0 a $0,9 \mu \mathrm{g}$, com a equação da reta $\mathrm{y}=-0,7471 \mathrm{x}+0,7769\left(\mathrm{R}^{2}=0,99\right)$, e de Trolox com concentrações de 0 a $10 \mu \mathrm{g} \cdot \mathrm{mL}^{-1}$ que correspondem às massas de 0 a $3 \mu \mathrm{g}$, com a equação da reta $y=-0,1713 x+0,7652\left(R^{2}=0,99\right)$.

\subsubsection{Captura do radical livre ABTS}

O ensaio da captura do radical livre ABTS foi realizado segundo o método de Torres et al. (em preparação), modificado de Rufino \& Alves (2007) e Yang et al. (2011). O método 
antioxidante total pela captura do radical livre ABTS é um dos mais utilizados e o seu fundamento é baseado na captura do radical ABTS. Com essa metodologia pode-se medir a atividade antioxidante de substâncias de natureza hidrofílica e lipofílica (Rufino \& Alves, 2007).

O ensaio de ABTS requer o preparo da solução reativa de ABTS 7,46 mM e a solução de persulfato de potássio $140 \mathrm{mM}$. Para a solução de ABTS foram pesados 3,84 mg de ABTS (Sigma-Aldrich, Brasil) e dissolvidos em $1 \mathrm{~mL}$ de água ultrapura. Para a solução de persulfato de potássio foram pesados 37,84 mg de persulfato de potássio (Sigma-Aldrich, Brasil) e dissolvidos em $1 \mathrm{~mL}$ de água ultrapura. A solução do radical ABTS foi composta pela mistura de $1 \mathrm{~mL}$ da solução de ABTS com 17,6 $\mu \mathrm{L}$ da solução de persulfato de potássio, esta solução foi mantida no escuro por 16 horas em temperatura ambiente. Após esse processo, a mistura foi diluída em metanol (razão de 1:88 v/v) até obter absorbância de 0,7 em 734 nm.

A mistura de reação foi preparada em penumbra com $280 \mu \mathrm{L}$ da solução reativa de ABTS $+20 \mu \mathrm{L}$ de extrato bruto de amostra e incubada por 20 min a temperatura ambiente e protegida da luz. Foram preparados diversos brancos para calibragem (branco de amostra e branco de metanol), além do controle ABTS. Após a reação, as leituras das absorbâncias foram feitas no comprimento de onda de $734 \mathrm{~nm}$.

A porcentagem de sequestro do radical ABTS (\% AAOX; atividade antioxidante) foi calculadade acordo com a seguinte fórmula:

$$
\% \text { AAOX ABTS }=\left[\left(\operatorname{Abs}_{\mathrm{ABTS}}-\mathrm{Abs}_{\mathrm{Amostra}}\right) / \mathrm{Abs}_{\mathrm{ABTS}}\right] \times 100
$$

onde: $\operatorname{Abs}_{\mathrm{ABTS}}=$ absorbância do controle ABTS (descontada a absorbância do branco metanol); Abs $_{\text {Amostra }}=$ absorbância da amostra com a solução reativa de ABTS (descontada a absorbância do branco amostra sem a solução reativa de ABTS).

A atividade antioxidante foi também expressa através de equivalente padrão de ácido gálico e Trolox ( $\mathrm{mg}$ eq. padrão.g $\mathrm{MF}^{-1}$ ). A curva de ácido gálico foi construída em concentrações de 0 a 1,5 $\mu \mathrm{g} \cdot \mathrm{mL}^{-1}$ que correspondem a massas de 0 a $0,45 \mu \mathrm{g}$, com equação da reta $\mathrm{y}=-1,5323 \mathrm{x}+0,8622\left(\mathrm{R}^{2}=0,99\right)$. Para a curva padrão de Trolox utilizou-se concentrações de 0 a $9 \mu \mathrm{g} \cdot \mathrm{mL}^{-1}$ que correspondem a massas de 0 a 2,7 $\mu \mathrm{g}$, com a equação da reta $\mathrm{y}=-0,2687 \mathrm{x}+0,9103\left(\mathrm{R}^{2}=0,99\right)$.

Os extratos procedentes da extração de pigmentos (extrato tamponado e extrato metanólico) também foram analisados na atividade sequestradora do radical ABTS. Os cálculos de equivalente padrão com os extratos de pigmentos foram realizados com base nas 
curvas padrões de ácido gálico com concentrações de 0 a $1,5 \mu \mathrm{g} \cdot \mathrm{mL}^{-1}$ que correspondem às massas de 0 a $0,45 \mu \mathrm{g}$, com a equação da reta $\mathrm{y}=-1,4152 \mathrm{x}+0,6375\left(\mathrm{R}^{2}=0,99\right)$. Para a curva padrão de Trolox utilizou-se concentrações de 0 a $9 \mu \mathrm{g} \cdot \mathrm{mL}^{-1}$ que correspondem às massas de 0 a 2,7 $\mu \mathrm{g}$, com a equação da reta $\mathrm{y}=-0,205 \mathrm{x}+0,618\left(\mathrm{R}^{2}=0,99\right)$.

Adicionalmente, foi calculado o EC50, concentração efetiva de extrato com capacidade de inibir $50 \%$ da atividade antioxidante, com auxílio do programa GraphPad Prism, seguindo o modelo sigmoide de dose-resposta. Os dados foram calculados a partir da porcentagem de atividade antioxidante nas diferentes concentrações de extrato bruto. Valores menores de EC50 representam extratos com melhor potencial antioxidante.

\subsubsection{Atividade quelante de metais}

Os metais também são capazes de gerar radicais livres. Na literatura existem vários métodos para estimar a atividade antioxidante, entre estes a capacidade de quelar de metais transição. A atividade quelante de íons ferro II $\left(\mathrm{Fe}^{2+}\right)$ foi realizada segundo a metodologia de Harb et al. (2016), modificado de Min et al. (2011). A ferrozina é um composto frequentmente utilizado na determinação de $\mathrm{Fe}^{2+}$. Na presença deste íon, a ferrozina forma um complexo rosa, cuja absorbância é determinada em $562 \mathrm{~nm}$. Quando há presença de agentes quelantes, menos íons $\mathrm{Fe}^{2+}$ estarão disponíveis para a formação do complexo com ferrozina, o que irá ocasionar decréscimo da absorbância em 562 nm.

Para o ensaio quelante de metais foi preparada a solução de sulfato de amônio ferroso $2 \mathrm{mM}$, pesando 2,4 mg de sulfato de amônio ferroso (Sigma-Aldrich, Brasil) e dissolvendo-os em 3 mL de água ultrapura, solução utilizada no dia. Também foram preparadas a soluções de acetato de amônio 10\%: $5 \mathrm{~g}$ de acetato de amônio (Sigma-Aldrich, Brasil) dissolvidos em água ultrapura para o volume final de $50 \mathrm{~mL}$; reagente de ferrozina 6,1 mM: $9 \mathrm{mg}$ de ferrozina (Sigma-Aldrich, Brasil) dissolvidos em água ultrapura para o volume final de $3 \mathrm{~mL}$.

A mistura de reação foi preparada em penumbra com $250 \mu \mathrm{L}$ da solução de acetato $10 \%+15 \mu \mathrm{L}$ da solução de sulfato de amônio $+20 \mu \mathrm{L}$ de extrato bruto de amostra e incubada por 5 min a temperatura ambiente e protegida da luz. Após esse período, foi adicionado $15 \mu \mathrm{L}$ da solução de ferrozina e incubada por 10 min com agitação de $100 \mathrm{rpm}$. Foram preparados diversos brancos para calibragem (branco de amostra e branco de metanol) e o controle quelante. Após a reação, as leituras das absorbâncias foram feitas no comprimento de onda de $562 \mathrm{~nm}$. 
A porcentagem de atividade quelante de metais (\% AAOX; atividade antioxidante) foi calculadade acordo com a seguinte fórmula:

$$
\% \mathrm{AAOX}=\left[\left(\mathrm{Abs}_{\text {Quelante }}-\mathrm{Abs}_{\mathrm{Amostra}}\right) / \mathrm{Abs}_{\text {Quelante }}\right] \mathrm{x} 100
$$

onde: $\mathrm{Abs}_{\text {Quelante }}=$ absorbância da mistura de acetato, sulfato de amônio, metanol e ferrozina (descontada a absorbância do branco metanol); Abs $_{\text {Amostra }}=$ absorbância da amostra com todos os reagentes da mistura de reação (descontada a absorbância do branco amostra com todos os reagents da mistura de reação menos a ferrozina).

A atividade antioxidante foi também expressa através de equivalente padrão de ácido gálico (mg eq. padrão.g $\mathrm{MF}^{-1}$ ). A curva de ácido gálico foi construída em concentrações de 0 a $10 \mu \mathrm{g} \cdot \mathrm{ml}^{-1}$ que correspondem às massas de 0 a $3 \mu \mathrm{g}$, com a equação da reta $\mathrm{y}=-0,2123 \mathrm{x}+$ 1,0462 ( $\mathrm{R}^{2}$ 0,98). Os cálculos de equivalente padrão com os extratos de pigmentos (extrato tamponado e extrato metanólico) foram realizados com base na mesma curva.

\subsubsection{Capacidade redutora do Folin-Ciocalteu}

A avaliação do potencial redutor dos extratos algais foi realizada pelo método do Folin-Ciocalteu, seguindo Pires et al. (em preparação), modificado de Singleton \& Rossi (1965) e Waterman \& Mole (1994).

Este ensaio é um método espectrofotométrico simples e baseia-se na propriedade redutora de algumas substâncias com poder redutor, como por exemplo, açúcares e fenóis, no qual, o reagente Folin-Ciocalteu, uma mistura de ácido fosfotúngstico-fosfomolíbdico, quando reage com as substâncias, apenas em condições alcalinas alcançadas com a adição de carbonato de sódio $\left(\mathrm{Na}_{2} \mathrm{CO}_{3}\right)$, ocorre dissociação de um próton levando à formação do ânion fenolato. O ânion é mais propenso a doar elétrons e capaz de reduzir o reagente, ou seja, tem maior capacidade redutora, formando assim um complexo azul de molibdênio (Genovese et al., 2003; Huang et al., 2005).

Para este ensaio, foi preparada uma solução saturada de carbonatro de sódio pesando $30 \mathrm{~g}$ de $\mathrm{Na}_{2} \mathrm{CO}_{3}$ (Sigma-Aldrich, Brasil) e dissolvendo-os em $100 \mathrm{~mL}$ de água ultrapura. A solução foi filtrada cada vez que o ensaio foi realizado.

A mistura de reação foi preparada com $200 \mu \mathrm{L}$ de água ultrapura $+20 \mu \mathrm{L}$ de extrato bruto de amostra $+20 \mu \mathrm{L}$ de Folin $2 \mathrm{~N}$ (Sigma-Aldrich, Brasil) $+60 \mu \mathrm{L}$ de $\mathrm{Na}_{2} \mathrm{CO}_{3}$ e incubada por $30 \mathrm{~min}$ em temperatura ambiente e protegido da luz. Foram preparados diversos 
brancos para calibragem (branco de amostra e branco de Folin). Após a reação, as leituras das absorbâncias foram feitas no comprimento de onda de $760 \mathrm{~nm}$.

A porcentagem de atividade antioxidante para o poder redutor do Folin-Ciocalteu (\% AAOX; atividade antioxidante) foi calculada considerando o valor da concentração de 13,3mg. $\mathrm{mL}^{-1}$ no tempo 0 (inicial) da irradiância de $60 \mu \mathrm{mol}$ fótons. $\mathrm{m}^{-2} \cdot \mathrm{s}^{-1}$ como $100 \%$.

A atividade antioxidante foi também expressa através de equivalente padrão de ácido gálico e Trolox (mg eq. padrão.g $\mathrm{MF}^{-1}$ ). Para os cálculos de equivalente padrão para o ensaio do Folin-Ciocalteu foram realizadas curvas padrões de ácido gálico (Sigma, Brasil) e Trolox (Aldrich, Brasil). A curva de ácido gálico foi construída em concentrações de 0 a $10 \mu \mathrm{g} \cdot \mathrm{ml}^{-1}$ que correspondem a massa de 0 a $3 \mu \mathrm{g}$, com a equação da reta $\mathrm{y}=0,2299 \mathrm{x}\left(\mathrm{R}^{2} 0,99\right)$. Para a curva padrão de Trolox utilizou-se concentrações de 0 a $100 \mu \mathrm{g} \cdot \mathrm{ml}^{-1}$ que correspondem a massa de 0 a $30 \mu \mathrm{g}$, com a equação da reta y =0,0469x $\left(\mathrm{R}^{2} 0,99\right)$. Os cálculos de equivalente padrão com os extratos de pigmentos (extrato tamponado e extrato metanólico) foram realizados com base nas mesmas curvas. Foi calculado o EC50 com auxílio do programa GraphPad Prism, seguindo o modelo sigmoide de dose-resposta.

\subsubsection{Ensaio da redução do ferro - FRAP}

A atividade antioxidante através do ensaio da redução do ferro - FRAP (do ingles Ferric Reducing Antioxidant Power) foi baseada no método de Urrea-Victoria et al. (2016), modificado de Brito et al. (2006). O método de FRAP surgiu como uma alternativa para determinar a redução do ferro em fluidos biológicos e soluções aquosas de compostos puros. Em pH ácido, o complexo tripiridil hidrazina férrica ( $\mathrm{Fe}^{3+} \mathrm{TPTZ}$ ) se reduz, produzindo intensa cor azul, o que pode ser monitorada pela medida da absorbância no comprimento de onda de $595 \mathrm{~nm}$. A reação não é específica e qualquer reação com baixo poder redutor, sob as condições de reação estabelecida, irá formar o íon ferroso $\left(\mathrm{Fe}^{2+}\right)$ a partir do íon férrico $\left(\mathrm{Fe}^{3+}\right)$. A mudança na absorbância está diretamente relacionada com o poder redutor total dos antioxidantes doadores de elétrons, presentes na mistura de reação (Tandon et al., 2008).

O ensaio do FRAP requer o preparo da solução reativa de FRAP, realizado a partir da combinação de $25 \mathrm{~mL}$ de tampão acetato $0,3 \mathrm{M}, 2,5 \mathrm{~mL}$ da solução TPTZ $10 \mathrm{mM}$ e 2,5 mL de uma solução aquosa de cloreto férrico $20 \mathrm{mM}$ (todos de Sigma-Aldrich, Brasil).

A mistura de reação foi preparada com $15 \mu \mathrm{L}$ de água ultrapura $+20 \mu \mathrm{L}$ de extrato bruto de amostra $+265 \mu \mathrm{L}$ da solução reativa FRAP e incubada por 30 min a $37^{\circ} \mathrm{C}$ e 
protegido da luz. Foram preparados diversos brancos para calibragem (branco de amostra e branco de FRAP). Após a reação, as leituras foram feitas no comprimento de onda de $595 \mathrm{~nm}$.

A porcentagem de atividade antioxidante para o FRAP (\% AAOX; atividade antioxidante) foi calculada considerando o valor da concentração de $13,3 \mathrm{mg} \cdot \mathrm{mL}^{-1}$ no tempo 0 (inicial) da irradiância de $60 \mu \mathrm{mol}$ fótons. $\mathrm{m}^{-2} \cdot \mathrm{s}^{-1}$ como $100 \%$.

A atividade antioxidante foi também expressa através de equivalente padrão de ácido gálico e Trolox ( $\mathrm{mg}$ eq. padrão.g $\mathrm{MF}^{-1}$ ). A curva de ácido gálico foi construída em concentrações de de 0 a $2 \mu \mathrm{g} \cdot \mathrm{mL}^{-1}$ que correspondem às massas de 0 a $0,6 \mu \mathrm{g}$, com a equação da reta $y=1,1231 x\left(R^{2} 0,95\right)$. Para a curva padrão de Trolox utilizou-se concentrações de 0 a $10 \mu \mathrm{g} \cdot \mathrm{mL}^{-1}$ que correspondem às massas de 0 a $3 \mu \mathrm{g}$, com a equação da reta $\mathrm{y}=0,4628 \mathrm{x}\left(\mathrm{R}^{2}\right.$ $=0,99$ ). Os cálculos de equivalente padrão com os extratos de pigmentos (extrato tamponado e extrato metanólico) foram realizados com base nas mesmas curvas. Foi calculado o EC50 com auxílio do programa GraphPad Prism, seguindo o modelo sigmoide de dose-resposta.

\subsection{Aminoácidos tipo micosporinas}

Na literatura são encontrados diversos métodos para a extração de MAAs. Alguns utilizam etanol como solvente, porém o mais comum é o metanol. Misturas de metanol/água em diferentes proporções também são empregadas, porém, são muito divergentes em cada método. Na literatura foram encontradas concentrações de metanol/água que se estendem de 20\% a 100\% (Carroll \& Schick, 1996; Banaszak et al., 1998; Karsten et al., 1998; Carreto et al., 2005; Cardozo, 2007; Lee \& Shiu, 2009; Barufi, 2010).

Visto essa variação nos procedimentos de extração, foi realizado um teste para definir a extração de MAAs no presente trabalho. Para tal, foram avaliados vários artigos e utilizaram-se como base para $P$. capillacea os estudos realizados por Korbee-Peinado et al. (2004), com três macroalgas vermelhas Porphyra leucosticta Thuret in Le Jolis, Gelidium latifolium Bornet ex Hauck e Corallina elongata J. Ellis \& Solander (ver detalhes em Anexo IV), sendo analisados extratos utilizando-se metanol $25 \%$ e metanol $100 \%$.

Após definir o método de extração, realizado a partir de amostras congeladas (200 mg MF) extraídas por $2 \mathrm{~h} \mathrm{a} 45^{\circ} \mathrm{C}$ com metanol $25 \%$, a análise foi realizada em cromatógrafo líquido de alta eficiência (CLAE) HPLC1260 (Agilent Technologies, EUA) baseando-se no método de Torres et al. (2015), modificado de Hartmann et al. (2015), que permite a identificação de cinco MAAs: porphyra-334, chinorina, palitina, asterina e palitinol. Para 
tanto, o sistema cromatográfico utilizou coluna Zorbax RX-SIL, 4,6x250mm $5 \mathrm{mu}$ com conector de $0,17 \times 90 \mathrm{~mm}$ (ideal para a fase normal), com cromatogramas processados em $\lambda=$ 225, 270, 320, 330 e $350 \mathrm{~nm}$. A fase móvel empregada consistiu de gradiente entre $\mathrm{A}=$ acetonitrila:acetato de amônio (1:1) e B = acetonitrila:acetato de amônio (9:1), com a seguinte programação: 0-15 min 20-55\% A; 15-16 min 55-20\% A; 16-22 min 20\% A, com fluxo de 1 mL.min ${ }^{-1}$, temperatura da coluna ajustada a $30^{\circ} \mathrm{C}$, com volume de injeção de $5 \mu \mathrm{L}$ e duração da corrida de 22 min. Esta metodologia foi realizada em colaboração com a Profa. Déborah Yara Alves Cursino dos Santos do Laboratório de Fitoquímica do IB-USP.

O perfil cromatográfico dos compostos presentes no extrato de P. capillacea foi realizada em HPLC1200 (Agilent Technologies, EUA). Para identificação dos compostos foi utilizado CLAE associado à espectrometria de massas em tandem por interface de ionização por electrospray (CLAE-IES-EM) (Shimadzu M10AVP - Esquire 3000 Plus - Brucker Daltonics, pais) na Central Analítica do Instituto de Química da USP. As condições no espectrômetro de massas foram: voltagem do capilar de $4000 \mathrm{~V}$, skimmer $40 \mathrm{~V}$, fluxo para o massa de $90 \mu \mathrm{L} \cdot \mathrm{min}^{-1}$, fluxo do gás secante de $7 \mathrm{~L} \cdot \mathrm{min}^{-1}$, temperatura de solvatação de $320^{\circ} \mathrm{C}$ e nebulizador a 2 psi. As condições cromatográficas foram as mesmas descritas acima.

\subsection{Análise de dados}

Todas as análises foram realizadas com tratamentos com cinco repetições. As análises estatísticas foram feitas com o programa Statistica 12 e Past. Os valores de porcentagem da atividade antioxidante foram transformados em arcoseno da raiz quadrada da proporção da porcentagem, segundo Snedecor (1966). Todos os dados foram testados quanto à normalidade (teste de Kolmogorov-Smirnov) e homocedasticidade (teste de Bartlett), dentro de um intervalo de confiança de $95 \%$ ( $\mathrm{p}<0,05$ ). Análises de variância (ANOVA) uni ou bifatoriais e análises multivariadas (PCA, análise de componentes principais) foram utilizadas para comparar os parâmetros estimados e avaliar as tendências preditivas do conjunto de descritores. As análises unifatoriais foram utilizadas para o cálculo estatístico de nível de pulso de saturação (ver detalhes em Anexo I) e das curvas de dose-resposta (ver detalhes em Anexo III) as demais análises foram bifatoriais. Comparações múltiplas dentre as diferenças significativas $(\mathrm{p}<0,05)$ após a ANOVA foram determinadas pelo teste post-hoc de NewmanKeuls. 


\subsection{Identificação taxonômica e molecular}

A identificação taxonômica por caracteres morfológicos foi realizada utilizando os trabalhos de Santelices \& Hommersand (1997), Santelices (1998), Millar \& Freshwater (2005) e Iha (2014).

Adicionalmente, a identificação da espécie foi validada por técnicas de biologia molecular, utilizando-se marcadores de "DNA barcode". Para tanto, o material algal de diferentes indivíduos $(\mathrm{n}=4)$ de $P$. capillacea, que estava preservado em sílica gel, foi triturado em nitrogênio líquido até a obtenção de um pó fino. As extrações de DNA foram feitas utilizando o kit NucleoSpin Plant II (Macherey-Nagel, Düren, Alemanha), seguindo as instruções do fabricante.

Após a extração foi realizada a reação em cadeia da polimerase (PCR) dos marcadores moleculares coxl, região 5' do gene que codifica a subunidade 1 da citocromo $c$ oxidase (COI-5P), presente no genoma mitocondrial ( $\sim 664 \mathrm{pb}$ ), os primers utilizados foram GWSLF3 (Saunders \& Moore, 2013) e GWSRn (Saunders, 2005). Após a PCR, os produtos foram analisados por eletroforese em gel de agarose $0,7 \%$, com marcador de tamanho $1 \mathrm{~Kb}$ DNA Ladder (Invitrogen, EUA) para verificar o sucesso da reação e os tamanhos dos fragmentos amplificados. Os produtos de PCR foram purificados em colunas " $G T X^{\mathrm{TM}} P C R D N A$ and Gel Band Purification Kit" (GE Healthcare, Buckinghamshire, Inglaterra), de acordo com o protocolo do fornecedor. O DNA total foi quantificado no NanoDrop 2000Spectrophotometer (Thermo Scientific, EUA) para posterior realização da reação de sequenciamento. O produto purificado foi sequenciado usando-se o "kit" BigDye Terminator Cycle Sequencing Ready Reaction (Applied Biosystems, EUA). As sequências obtidas nas direções direta e reversa foram alinhadas manualmente usando o programa BioEdit 7.0.4.1 e os nucleotídeos divergentes ocorrendo na mesma posição foram verificados manualmente nos cromatogramas das sequências. Cada sequência obtida de cada amostra foi comparada com as sequências disponíveis no GenBank (http://www.ncbi.nlm.nih.gov), com o uso do programa BLAST (Altschul et al., 1990). As sequências consenso dos "DNA barcodes", coxl de todas as amostras, foram alinhadas em uma matriz no programa MEGA 7 (Tamura et al., 2011) e, então, feita uma árvore de agrupamento por máxima verossimilhança, com 2.000 réplicas de Bootstrap, para o marcador, no mesmo programa. 


\section{Referências bibliográficas}

Abou Zeid AH.; Aboutabl EA.; Sleem AA.; El-Rafie HM. 2014. Water soluble polysaccharides extracted from Pterocladia capillacea and Dictyopteris membranacea and their biological activities. Carbohydr. Polym. 113: 62-66p.

Albino J. 1999. Morfodinâmica e processo de sedimentação atual das praias de Bicanca à Povoação, ES. Tese de doutorado. Instituto de Geociências. Universidade de São Paulo. São Paulo. 178p.

Alencar DB.; de Carvalho FCT.; Rebouças RH.; dos Santos DR.; dos Santos Pires Cavalcante KM.; de Lima RL.; Baracho BM.; Bezerra RM.; Viana FA.; dos Fernandes Vieira RHS.; Sampaio AH.; de Sousa OV.; Saker-Sampaio S. 2016. Bioactive extracts of red seaweeds Pterocladiella capillacea and Osmundaria obtusiloba (Floridophyceae: Rhodophyta) with antioxidant and bacterial agglutination potential. Asian Pac. J. Trop. Med. 9: 372379.

Algaebase. 2015. Disponível em <http://www.Algaebase.Org/Search/Genus/Detail/?Genus_ $\mathrm{Id}=$ Fe565bce86160a251\&-Session=Abv4:Bd7894fc1b0df01418wt6935a94a $>$ Acesso em $13 / 06 / 2016$.

Appelhans YS.; Lenz M.; Medeiros HE.; Gama BAP.; Pereira RC.; Wahl M. 2010. Stressed, but not defenceless: no obvious influence of irradiation levels on antifeeding and antifouling defences of tropical macroalgae. Mar. Biol. 157: 1151-1159.

Aguilera J.; Karsten U.; Lippert H.; Vögele B.; Philipp E.; Hanelt D.; Wiencke C. 1999. Effects of solar radiation on growth, photosynthesis and respiration of marine macroalgae from the arctic. Mar. Eco. Prog. Ser. 191: 109-119.

Araújo FO.; Ursi S.; Plastino EM. 2014. Intraespecific variation in Gracilaria caudata (Gracilariales, Rhodophyta): growth, pigment content, and photosynthesis. J. Appl. Phycol. 26:849-858.

Ayres-Ostrock LM.; Plastino EM. 2014a. Effects of short-term exposure to ultraviolet-B radiation on photosynthesis and pigment content of red (wild types), greenish-brown, and green strains of Gracilaria birdiae (Gracilariales, Rhodophyta). J. Appl. Phycol. 26:867879.

Ayres-Ostrock LM.; Plastino EM. 2014b. Effects of UVB radiation on growth rates, pigment contents, and ultrastructure of red (wild types), greenish-brown, and green strains of Gracilaria birdiae (Gracilariales, Rhodophyta). J. Appl. Phycol. 49:197-212. 
Bandaranayake WM. 1998. Mycosporines: are they nature's sunscreens? Nat. Prod. Rep. 15: $159-172$.

Banaszak AT.; Lesser MP.,; Kuffner IB.; Ondrusek M. 1998. Relationship between ultraviolet (UV) radiation and mycosporinelike amino acids (MAAs) in marine organisms. B. Mar. Sci. 63: 617-628.

Barbosa So.; Figueiredo Mao.; Testa V. 2008. Estrutura e dinâmica de comunidades bentônicas dominadas por macrófitas na zona intramareal da praia de Jacaraípe, Espírito Santo, Brasil. Hoehnea 35: 563-575.

Barufi JB. 2010. Fotoproteção em Gracilaria tenuistipitata (Rhodophyta): uma abordagem fisiológica e molecular. Tese de doutorado. Instituto de Biociências. Universidade de São Paulo. São Paulo. 325p.

Barufi JB.; Korbee N.; Oliveira MC. ; Figueroa FL. 2010. Effects of N supply on the accumulation of photosynthetic pigments and photoprotectors in Gracilaria tenuistipitata (Rhodophyta) cultured under UV radiation. J. Appl. Phycol. 23: 457-466.

Barufi JB.; Mata M; Oliveira MC.; Figueroa FL. 2012. Nitrate reduces the negative effect of UV radiation on photosynthesis and pigmentation in Gracilaria tenuistipitata (Rhodophyta): the photoprotection role of mycosporine-like amino acids. Phycologia 51:636-648.

Barufi JB.; Figueroa FL.; Plastino EM. 2015. Effects of light quality on reproductions, growth and pigment content of Gracilaria birdiae (Rhodophyta: Gracilariales). Sci. Mar. 79: 1524.

Berchez FAS. 1985. Aspectos da ecologia e biologia da alga agarófita Pterocladia capillacea (Rhodophyta, Gelidiaceae). Tese de doutorado. Instituto de Biociências. Universidade de São Paulo. São Paulo. 130p.

Berchez FAS.; EC Oliveira. 1990. Growth rate, in vitro, of the agar producing seaweed Pterocladia capillacea (Rhodophyta, Gelidiaceae) under different conditions of light, temperature and nutrients. Rev. Bras. Bot. 13: 55- 59.

Bischof K.; Steinhoff F. 2012. Impacts of stratospheric ozone depletion and solar UVB radiation on seaweeds. Seaweed Biol. 433-448p.

Bixler HJ.; Porse H. 2011. A decade of change in the seaweed hydrocolloids industry. J. Appl. Phycol. 23: 321-335. 
Boo SM.; Su YK. 2010. In: Sh. Il, Kh. Reexamination of the genus Pterocladiella (Gelidiaceae, Rhodophyta) in korea based on morphology and rbcl sequences. Algae. 25: $1-9$.

Bottalico A.; Delle Foglie CI.; Fanelli M. 2008. Growth and reproductive phenology of Pterocladiella capillacea (Rhodophyta: Gelidiales) from the southern Adriatic Sea. Bot. Mar. 51: 124-131.

Bouzon ZL.; Chow F.; Simioni C.; Santos RW.; Ouriques LC.; Felix MRL.; Osorio LKP.; Gouveia C.; Martins RP.; Latini A.; Ramlov F.; Maraschin M.; Schmidt EC. 2012a. Effects of natural radiation, photosynthetically active radiation and artificial ultraviolet radiation-B on the chloroplast organization and metabolism of Porphyra acanthophora var. brasiliensis (Rhodophyta, Bangiales). Microsc. Microanal. 18: 1467- 1479.

Buck CB.; Thompson CD.; Roberts JN.; Müller M.; Lowy DR.; Schiller JT. 2006. Carrageenan is a potent inhibitor of papillomavirus infection. Plos Pathogens. 2:671-680.

Bradford M. 1976. A rapid sensitive method for the quantification of microgram quantities of protein utilizing the principle of protein-dye binding. Anal. Biochem.72: 248-254.

Brand-Williams W.; Cuvelier ME.; Berset C. 1995. Use of a free radical method to evaluate antioxidant activity. Food Sci. Tech. 28: 25-30.

Brito ES. De; Morais SM. De; Sampaio CDG.; Saura-Calixto FD. 2006. Metodologia Científica: determinação da atividade antioxidante total em frutas pelo método de redução do ferro (FRAP). Embrapa 3-6.

Calabrese G.; Felicini GP. 1970. Ricerche sui pigmenti delle alghe rosse. I: analisi qualitativa e quantitativa dei pigmenti di Pterocladia capillacea (Gmel.) Born. et Thur. coltivata in presenza di alcune fonti minerali di azoto. G. Bot. Ital. 104: 81-89.

Callone AI.; Carignan M.; Montoya NG; Carreto JI. 2006. Biotransformation of mycosporine like amino acids (maas) in the toxic dinoflagellate Alexandrium tamarense. $J$. Photochem. Photobiol. B. 84: 204-212.

Camilloni I.; Bidegain M. 2005. Escenarios climáticos para el siglo XXII. In: Barros, V.; Menéndez, Á. Nagy, G. (Ed.). El cambio climático en el río De la Plata. Buenos Aires: Cima/Conicet/Uba 33-39.

Campo VL.; Kawano DF.; Silva Jr., DB.; Carvalho I. 2009. Carrageenans: biological properties, chemical modifications and structural analysis - A review. Carbohyd. Polymers 77:167-180. 
Cardozo KHM. 2007. Estudos de compostos fotoprotetores da radiação ultravioleta em algas: aminoácidos tipo micosporinas (MAAs). Tese de doutorado. Universidade de São Paulo. São Paulo. 173p.

Cardozo KHM.; Guaratini T.; Barros MP.; Falcão VR.; Tonon AP.; Lopes N. 2007. Metabolites from algae with economical impact. Comp. Biochem. Physiol. Comp. Biochem. Physiol. C. Toxicol. Pharmacol. 146: 60-78.

Carignan MO.; Montoya NG.; Carreto JI. 2002. Long-term effects of ultraviolet radiation on the composition of pigment and mycosporine-like amino acids (MAAs). Aquacult. Environ. Mar. Phy. 191-207.

Carnicas E.; Jimenez C.; Niell FX. 1999. Effects of changes of irradiance on the pigment composition of Gracilaria tenuistipitata Var. Liui Zhang Et Xia. J. Photochem. Photobiol. B. 50:149-158.

Carreto JI.; Carignana MO.; Dal Cl.; Marco SG. 1990. Occurrence of mycosporine-like amino acids in the red tide dinoflagellate Alexandrium excavatum. Uv-Photoprotective Compounds.J. Plankton Res. 12: 909-92.

Carreto JI.; Carignan MO.; Montoya NG. 2001. Comparative studies on mycosporine-like amino acids, paralytic shellfish toxins and, pigment profiles of the toxic dinoflagellates alexandrium tamarense, A. catenella and A. minutum. Mar. Ecol. Prog. Ser. 223: 49-60.

Carreto JI.; Carignan MO.; Montoya NG. 2005. A high resolution reverse-phase liquid chromatography method for the analysis of mycosporine-like amino acids (MAAs) in marine organisms. Mar. Biol. 146: 237-252.

Carroll AK.; Shick JM. 1996. Dietary accumulation of mycosporine-like amino acids (maas) by the green sea urchin (Strongylocentrotus droebachiensis). Mar. Biol. 124: 561-569.

Connan S.; Delisle F.; Deslandes E.; Gall E. 2006. Intra-thallus phlorotannin content and antioxidant activity in phaeophyceae of temperate waters. Bot. Mar. 49: 39-46.

Coutinho R.; Yoneshigue Y. 1988. Diurnal variation in photosynthesis vs. Irradiance curves from "sun" and "shade" plants of Pterocladia capillacea (Gmelin) bornet et thuret (Gelidiaciaceae: Rhodophyta) from Cabo Frio, Rio De Janeiro, Brazil. J. Exp. Mar. Biol. Ecol.118: 217-228.

Cordeiro RA.; Gomes VM.; Carvalho AFU.; Mello VMM. 2006. Effects of protein from seaweed Hypnea musciformis (Wulfen) lamouroux on the growth of human pathogeny yeasts. Braz. Arch. Biol. Technol. 49: 915-92. 
Cos P.; Hermans N.; Calomme M.; Maes L; De Bruyne T.; Pieters L.; Vliettinck AJ.; Vanden Berghe D. 2003. Comparative study of eight well-known polyphenolic antioxidants. $J$. Pharm. Pharmacol. 55: 1291-1297.

Claustre H.; Gostan J. 1987. Adaptation of biochemical composition and cell size to irradiance in two microalgae: possible ecological implications. Mar. Ecol. Prog. Ser. 40: 167-174.

Chen Z.; Bertin R.; Froldi G. 2013. EC 50 estimation of antioxidant activity in $\mathrm{DPPH}^{\bullet}$ assay using several statistical programs. Food Chem. 138: 414-420.

Dawes CJ.; Orduña-Rojas J.; Robledo D. 1999. Response of the tropical red seaweed Gracilaria cornea to temperature, salinity and irradiance. J. Appl. Phycol. 10: 419-425.

Delwiche CF., Kuhsel M.; Palmer JD. 1995. Phylogenetic analysis of tuf a sequences indicates a cyanobacterial origin of all plastids. Mol. Phylogenet. Evol. 4: 110-12.

Demming B.; Winter K.; Kruguer A.; Cyzigan FC. 1988. Zeaxanthin and the heat dissipation of excess light energy in nerium oleander exposed to a combination of high light and water stress. Plant Physiol. 87: 17-24.

Dunton KH.; Schell DM. 1987. Dependence of consumers on macroalgal (Laminaria solidungula) carbon in an artic kelp community. Mar. Biol. 93:615- 625.

Diretoria de Hidrografia e Navegação (DHN). 2005. Tábuas Das Marés. Porto Do Tubarão.

Edwards P. 1970. Illustrated guide to the seaweeds and sea grasses in the vicinity of Porto Aransas, Texas. Contr. Mar. 15: 1-228.

Errea MI.; Matulewicz MC. 1994. Cold water-soluble polysaccharides from tetrasporic Pterocladia capillacea. Phytochemistry 37: 1075-1078.

Errea MI.; Matulewicz MC. 1996. Hot water-soluble polysaccharides from tetrasporic Pterocladia capillacea. Phytochemistry 42: 1071-1073.

Errea MI.; Matulewicz MC. 2003. Unusual structures in the polysaccharides from the red seaweed Pterocladiella capillacea (Gelidiaceae, Gelidiales). Carbohydr. Res. 338:943953.

El Kassas HY.; Attia AA. 2014. Bacterial application and cytotoxic activity of biosynthesized silver nanoparticles with an extract of red seaweed Pterocladiella capillacea on the HepG2 cell line. Asian Pac. J. Cancer. Prev. 15: 1299-1306. 
Esteban R.; Martínez B.; Fernández-Marín B.; Becerril JM; García-Plazaola JI. 2009. Carotenoid composition in Rhodophyta: insights into xanthophyll regulation in Corallina elongata. Euro J. Phycol. 44: 221-230.

Falkowski PG. 1980. Light-shade adaptation in marine phytoplankton. In falkowski, p. G. (Ed.), primary productivity in the sea. Plenum. Press. 531p.

FAO. Food and Agriculture Organization of the United Nations. 2012. El estado mundial de la pesca y la acuicultura Disponível em < http://www.fao.org/docrep/016/i2727s/i2727s.pdf> Acesso em 27/05/2015.

FAO. Food and Agriculture Organization of the United Nations. 2014. Fisheries and aquaculture information and statistics service. Disponível em <http://www.fao.org/3/ai3720s.pdf> Acesso em 14/06/2016.

Felicini GP.; Arrigoni O. 1967. Ricerche sulla rigenerazione in coltura di Pterocladia capillacea. G. Bot. Ital. 101: 199-217.

Felicini GP. 1970. Ricerche sulla rigenerazione in coltura di Pterocladia capillacea. Influenza della intensita luminosa sulla morfologia del tallo. G. Bot. Ital. 104: 35-47.

Felicini GP.; Perrone C. 1972. Sulla formazione di galle nella rigenerazione di Pterocladia capillacea (Gmel.) Born. et Thur. in coltura. G. Bot. Ital. 106: 351-358.

Felicini GP.; Perrone C. 1986. Une e tude en lumiere polarize e sur le parcours des hyphes dans le thalle de Pterocladia capillacea. Phycologia 25: 37-46.

Felicini GP. 1992. Colonization of artificial substrata with the agarophyte Pterocladia capillacea (Gelidiaceae, Rhodophyta): some basic criteria. G. Bot. Ital. 126: 738-740.

Felicini GP.; Bottalico, A.; Fanelli M. 2002. Morphogenesis in Pterocladiella capillacea (Rhodophyta, Gelidiales): bud differentiation in relation to irradiance-temperature combinations. Plant Biosyst. 136: 261-268.

Felix MR.; Osorio LKP.; Ouriques LC.; Farias-Soares FL.; Steiner N.; Kreusch M.; Pereira, DT.; Simioni C.; Costa GB.; Horta PA.; Chow F.; Ramlov F.; Maraschin M.; Bouzon ZL.; Schmidt EC. 2014. The effect of cadmium under different salinity conditions on the cellular architecture and metabolism in the red alga Pterocladiella capillacea (Rhodophyta, Gelidiales). Microsc. Microanal. 1:1-14.

Fernandes S.; Guimarães SMPB. 1998. Estudos taxonômicos de Gelidiales (Rhodophyta) do estado do Espírito Santo, Brasil. In An do IV Congr. Latino-Americano, II Reun. IberoAmericana e VII Reun. Bras. Ficol. Ii: 181-201. 
Ferraces-Casais P.; Lage-Yusty MA.; Quirós ARB.; López Hernández J. 2011. Evaluation of bioactive compounds in fresh edible seaweeds food anal. Food Anal. Method. 5: 828-834.

Ferrario M.; Sar E. 1996. Macroalgas de interes econômico. Cultivo, manejo, industrialización. Editorial de La Universidad Nacional de La Plata. La Plata, Argentina. $296 p$.

Ferreira CEL; Gonçalves JEA.; Coutinho R. 2001. Community structure of fishes and habitat complexity on a tropical rocky shore. Environ. Biol. Fish. 61: 353-369.

Figueroa FL.; Nygard C.; Ekelund N.; Goméz I. 2003. Photobiological characteristics and photosynthetic uv responses in two Ulva species (Chlorophyta) From Southern Spain. $J$. Photochem. Photobiol. B. 72:35-44.

Figueroa FL.; Israel A.; Neori A.; Martínez B.; Malta EJ.; Put A.; Inken S.; Marquardt R.; Abdala R.; Korbee N. 2010. Effect of nutrient supply on photosynthesis and pigmentation to short-term stress (UV radiation) in Gracilaria conferta (Rhodophyta). Mar. Pollut. Bull. 60: 1768-1778.

Figueroa FL.; Korbee N.; Abdala R.; Jerez CG.; López-de la Torre M. 2012. Biofiltration of fishpond effluents and accumulation of N-compounds (phycobiliproteins and mycosporine-like amino acids) versus C-compounds (polysaccharides) in Hydropuntia cornea (Rhodophyta). Mar. Pollut. Bull. 64: 310-318.

Fujimoto K.; Kaneda T. 1980. Screening test for antioxigenic compounds from marine algae and fraction from eisenia bicyclis and undaria pinnatifida. Bull Japan Soc. Sci. Fisheries 46: $1125-1130$.

Furlan CM.; Santos DYAC.; Chow F. 2008. A botânica do cotidiano. São Paulo: Instituto de Biociências da USP. 124p.

Franklin L.; Kräbs G.; Kuhlenkamp R. 2001. Blue light and UV-A radiation control the synthesis of mycosporine-like amino acids in Chondrus crispus (Florideophyceae). $J$. Phycol. 37: 257-270.

Friedlander M.; N Zelikovitch. 1984. Growth rates, phycocolloid yield and quality of the red seaweeds Gracilaria sp., Pterocladia capillacea, Hypnea musciformis and Hypnea cornuta in field studies in Israel. Aquaculture 40: 57-66.

Gal-Or S.; Israel A. 2004. Growth responses of Pterocladiella capillacea (Rhodophyta) in laboratory and outdoor cultivation. J. Appl. Phycol. 16: 195-202. 
Garbary DJ.; Gabrielson PW. 1990. Taxonomy and evolution. In K. M. Cole and R. G. Sheath [eds.], Biology of the red algae, 477-498. Cambridge University Press, Cambridge, UK.

Genovese MI.; Santos RJ.; Hassimotto NMA.; Lajolo FM. 2003. Determinação do conteúdo de fenólicos totais em frutas. Rev. Bras. Ciên. Farm. 39: 167-9.

Gomes EN. 2006. Medidas e modelos de estimativa da radiação direta na incidência. Tese de doutorado. Faculdade de Ciências Agronômicas. Universidade Estadual Paulista. Botucatu. 97p.

Guimarães M. 2000. Aspectos fisiológicos de Gracilaria domingensis (Gracilariales, Rhodophyta): subsídios para a compreensão da manutenção do polimorfismo pigmentar. Tese de doutorado. Universidade de São Paulo. São Paulo. 89 p.

Guimarães SMPB. 2003. Uma análise da diversidade da flora marinha bentônica do estado do Espírito Santo, Brasil. Hoehnea 30: 11-19.

Guimarães SMPB. 2006. A revised checklist of benthic marine Rhodophyta from the state of Espírito Santo, Brazil. Bol. do Inst. Bot. 17: 143-194.

Guiry MD.; Womersley HBS. 1993. Capreolia implexa gen. et sp. nov. in Australia and New Zealand (Gelidiales, Rhodophyta); an intertidal red alga with an unusual life history. Phycologia 32: 266-277.

Graham LE.; Wilcox LW.; Graham J. 2009. Algae. 2ed. Prentice-Hall, New Jersey.

Groniger A.; Hallier C.; Häder DP. 1999. Influence of UV radiation and visible light on porphyra umbilicalis: photoinhibition and maa concentration. J. Appl Phycol. 11:437-445.

Grzymski J.; Johnsen G.; Sakshug E. 1997. The significance of intracellular self-shading on the bio-optical properties of brown, red and green macroalgae. J. Phycol. 33: 408-414.

Haijin M.; Xiaolu J.; Huashi GA. 2003. K-carrageenan derived oligosaccharide prepared by enzymatic degradation containing anti-tumor activity. J. Appl. Phycol.15: 297-303.

Hamada E.; Gonçalves RRV.; Ghini R. 2012. Metodologia de elaboração de mapas dos cenários climáticos futuros do terceiro relatório do IPCC para o brasil. In: workshop sobre mudanças climáticas e problemas fitossanitários, jaguariúna. Anais Jaguariúna: Embrapa Meio Ambiente.

Halliwell B.; Whiteman M. 2004. Measuring reactive species and oxidative damage in vivo and in cell culture: how should you do it and what do the results means. Br. J. Pharmacol. 142: 231-255. 
Halliwell B.; Gutteridge JMC. 2006. Free radicals in biology and medicine. 4 Ed. New York: Oxford University Press. 704p.

Harb TB.; Torres PB.; Pires JS.; Dos Santos DYAC.; Chow F. 2016. Ensaio em microplaca do potencial antioxidante através do sistema quelante de metais para extratos de algas. Instituto de Biociências, Universidade de São Paulo. ISBN 978-85-85658-63-2 1-5.

Hartmann A.; Becker K.; Karsten U.; Remias D.; Ganzera M. 2015. Analysis of mycosporinelike amino acids in selected algae and cyanobacteria by hydrophilic interaction liquid chromatography and a novel MAA from the red alga Catenella repens. Mar. Drugs 13: 6291-6305.

Henley WJ.; Ramus J. 1989. Time course of physiological response of Ulva rotundata to growth irradiance transitions. Mar. Ecol. Prog. Ser. 54:171-177.

Herzig R.; Dubinsky Z. 1992. Photoacclimation, photosynthesis, and growth in phytoplankton. Israel J. Bot. 41: 99-212.

Holdt SL.; Kraan S. 2011. Bioactive compounds in seaweed: functional, food applications and legislation. J. Appl. Phycol. 23:543-597.

Hommersand MH.; Fredericq S. 1996. Vegetative and reproductive development of Pterocladia capillacea (Gelidiales, Rhodophyta) from La Jolla, California. Nova Hedwigia 112: 147-160.

Horta PA.; Amancio E.; Coimbra CS.; Oliveira EC. 2001. Considerações sobre a distribuição e origem da flora de macroalgas marinhas Brasileiras. Hoehnea 28: 243-265

Hoyer K.; Karsten U.; Wiencke C. 2002. Induction of sunscreen compounds in Antarctic macroalgae by different radiation conditions. Mar. Biol. 141:619-627.

Huang D.; Ou B.; Prior R. 2005. The chemistry behind antioxidant capacity assays. J. Agric. Food Chem. 53: 1841-1856.

IBGE. 2010. Censo Populacional. Instituto Brasileiro de Geografia e Estatística (IBGE) (29 de novembro de 2010). Visitado em 02 de fevereiro de 2015.

Iha C. 2014. Diversidade de Gelidiales (Rhodophyta) baseada em marcadores moleculares e estudos morfoanatômicos para região sudeste do brasil. Dissertação de mestrado. Instituto de Biociências. Universidade de São Paulo. São Paulo. 142p.

Jamas M. 2015. Diversidade de Gelidiales (Rhodophyta) no Brasil, com ênfase na região nordeste, com base em estudos morfológicos e DNA barcodes. Dissertação de mestrado. Instituto de Botânica da Secretaria de Estado do Meio Ambiente. 127p. 
Jassby AD.; Platt T. 1976. Mathematical formulation of the relationship between photosynthesis and light for phyto-plankton. Limnol. Oceanogr. 21: 540-547.

Jeffrey SW.; Mactavish HS.; Dunlap WC.; Vesk M.; Groenewoud K. 1999. Occurrence of uva- and uvb-absorbing compounds in 152 species (206 strains) of marine microalgae. Mar. Ecol. Prog. Ser. 189: 35-51.

Joly AB. 1957. Contribuição ao conhecimento da flora ficológica marinha da baía de santos e arredores. Bol. da Fac. Filos Ciências e Let. Univ. 14: 1-196.

Joly AB. 1965. Flora marinha do litoral norte do estado de São Paulo e regiões circunvizinhas. Bol. da Fac. Filos Ciências e Let. Univ. 21: 21-294.

Kakita H.; Kamishima H. 2006. Effects of environmental factors and metal ions on growth of the red alga Gracilaria chorda Holmes (Gracilariales, Rhodophyta). J. Appl. Phycol. 18: 469-474.

Karentz D. 2001. Chemical defenses of marine organisms against solar radiation exposure: uv-absorbing mycosporine-like amino acids and scytonemin. Mar. Chem. Ecol. 15: 481$520 \mathrm{p}$.

Karsten U.; Franklin LA.; Lüning K.; Wiencke C. 1998. Natural ultraviolet radiation and photosynthetically active radiation induce formation of mycosporine-like amino acids in the marine macroalga chondrus crispus (Rhodophyta). Planta 205: 257-262.

Karsten U.; Wulff A.; Roleda MY.; Muller R.; Steinoff F.; Fredersdorf J.; Wiencke C. 2011. Physiological responses of polar benthic algae to ultraviolet radiation. Bot. Mar. 52: 639654.

Kilinç B.; Cirik S.; Turan G.; Tekogul H.; Koru E. 2013. Seaweeds for food and industrial applications. Disponível Em: Http://Cdn.Intechopen.Com/Pdfs/41694/Intechseaweeds_For_Food_And_Industrial_App licati Ons.Pdf. Acesso em: 14/06/2016.

Kinoshita LS.; Teixeira C. 1979. Produção primáiria de Pterocladia capilacea (Gelidiaceae Rhodophyta). Bot. Int. Oceanog. 28: 29-36.

Kirihara S.; Fujikawa Y.; Notoya M. 1997. Axenic tissue culture of Sargassum confusum C. Agardh (Phaeophyta) as a source of seeds for artificial marine forests. J. Mar. Biotech. 5: 142-146.

Kirk JTO. 1994. Light and photosynthesis in aquatic ecosystems. $2^{\text {a }}$ Ed. Cambridge Univ. Press, 662p. 
Korbee-Peinado N.; Díaz RTA.; Figueroa FL.; Helbling EW. 2004. Ammonium and UV radiation stimulate the accumulation of mycosporine-like amino acids in porphyra columbina (Rhodophyta) from patagonia. Argent. J. Phycol. 40: 248-259.

Korbee N.; Figueroa FL.; Aguilera J. 2005. Effect of light quality on the accumulation of photosynthetic pigments, proteins and mycosporine-like amino acids in the red alga Porphyra leucosticta (Bangiales, Rhodophyta). J. Photochem. Photobiol. B. 80: 71-78.

Korbee N.; Figueroa FL; Aguilera J. 2006. Acumulación de aminoácidos tipo micosporina (MAAs): biosíntesis, fotocontrol y funciones ecofisiológicas. Rev. Chil. Hist. Nat. 79:119-132.

Kursar TA.; Van Der Meer J.; Alberte RS. 1983. Light-harvesting system of the red alga Gracilaria tikvahiae. I. Biochemical Analyses of Pigments Mutation. Plant Physiol.73: 353-360.

Kräbs G.; Bischof K.; Hanelt D.; Tüg H.; Wienke C. 2002. Wavelength-dependence induction of UV-absorbing mycosporine-like amino acids in the red alga Chondrus crispus under natural solar radiation. Mar. Biol. 268: 69-82.

Kräbs G.; Watanabe M.; Wiencke CA. 2004. Monochromatic action spectrum for the photoinduction of the UV-absorbing mycosporine-like amino acid shinorine in the red alga Chondrus crispus. J. Photochem. Photobiol. B. 79:515-519.

Lee TM.; Shiu CT. 2009. Implications of mycosporine-like amino acid and antioxidant defenses in UV-B radiation tolerance for the algae species Pterocladiella capillacea and Gelidium amansii. Mar. Environ. Res. 67: 8-16.

Lewitus AJ.; Caron DA. 1990. Relative effect of nitrogen or phosphorus depletion and light intensity on the pigmentation, chemical composition, and volume of Pyrenomonas salina (Cryptophyceae). Mar. Ecol. Prog. Ser. 61: 171-181.

Lichtenthaler HK.; Buschmann C. 2001. 'Chlorophylls and carotenoids: measurement and characterization by UV-VIS spectroscopy', in 'Current protocols in food analytical chemistry' 431-438p.

Litchman E.; Neale PJ.; Banaszak AT. 2002. Increased sensitivity to ultraviolet radiation in nitrogen-limited dinoflagellates: photoprotection and repair. Limnol. Oceanogr. 47:8689.

Lobban CS.; Harrison PJ. 2000. Seaweed ecology and physiology. $3^{\text {a }}$ Ed., Cambridge Univ.Press, Cambridge, 366p. 
Macartain P.; Christopher RG.; Brooks M.; Campbell R.; Rowland IR. 2007. Nutritional value of edible seaweeds. Nutr. Rev. 65: 535- 543.

Machado LP.; Carvalho LR.; Young MCM.; Cardoso-Lopes EM.; Centeno Danilo C.; Zambotti-Vilella L.; Colepicolo P.; Yokoya NS. 2015. Evaluation of acetylcholinesterase inhibitory activity of Brazilian red macroalgae organic extracts. Rev. Bras. Farmac. 25: 657-662.

Mamatha BS.; Namitha KK.; Senthil A.; Ravishankar GA. 2007. Studies on use of enteromorpha in snack food. Food Chem. 101:1707-1713.

Marengo JA. 2001. Mudanças climáticas globais e regionais: avaliação do clima atual do Brasil e projeções de cenários climáticos do futuro. Rev. Bras. Meteorol. 16:1-18.

Marengo JA.; Nobre CA.; Salati E.; Ambrizzi T. 2007. Caracterização do clima atual e definição das alterações climáticas para o território brasileiro ao longo do século XXI. Sumário Técnico. Nma .Sbf. Dcbio. 50p.

Marques LG. 2015. Aminoácidos tipo micosporina: novas metodologias e distribuição em macroalgas da costa brasileira. Tese de doutorado. Instituto de Química. Universidade de São Paulo. São Paulo. 152p.

Martínez B.; Rico J. 2008. Changes in nutrient content of Palmaria palmata in response to changes in nutrient to variable light and upwelling in northern Spain. J. Phycol. 44:50-59.

Maschek JA.; Baker BJ. 2008. The chemistry of algal secondary metabolism. In Amsler, C.D. (Ed.). Algal Chem. Ecol.1-24.

Maxwell K.; Johnson GN. 2000. Chlorophyll fluorescence - a practical guide. J. Exp. Bot. 51: 659-668.

Mercado JM., Jiménez C.; Niell FX.; Figueroa FL. 1996. Comparison of methods for measuring light absorption by algae and their application to the estimation of package effect. Sci. Mar. 60: 39-45.

Melo VMM.; Medeiros DA.; Rios FJB.; Catelar LIM.; Carvalho ADFFU. 1997. Antifungal properties of proteins (aglutinins) of the red alga Hypnea musciformis. Bot. Mar. 40: 281284.

Millar AJK.; Freshwater DW. 2005. Morphology and molecular phylogeny of the marine algal order Gelidiales (Rhodophyta) from New South Wales, including Lord Howe and Norfolk Island. Aust. Syst. Bot. 18: 215-263. 
Min B.; Mcclung AM.; Chen M-H. 2011. Phytochemicals and Antioxidant Capacities In Rice Brans of Different Color. J. Food Sci. 76:117-26p. Disponível em< Http://Www.Ncbi.Nlm.Nih.Gov/Pubmed/21535639> Acesso em 14/06/2016.

Moll B.; Deikman J. 1995. Enteromorpha clatharata: a potencial seawater-irrigated crop. Biores. Technol. 52: 225-260.

Monro K.; Poore AGB. 2005. Light quantity and quality induce shade-avoiding plasticity in a marine macroalga. J. Evolut. Biol. 18: 426-435.

Müller P.; Li X.-P.; Niyogi KK. 2001. Non-photochemical quenching. A response to excess light energy. Plant Physiol. 125:1558-1566.

McCree KJ. 1981. Photsynthetically Active Radiation. Envyvlopedia of Plant Physiology. New Series, Physiol. Plant Ecol. 1-12p.

Mcfadden GI. 2001. Chloroplast origin and integration. Plant Physiol. 125: 50-53.

Mchugh DJ. 2002. Perspectivas para la producción de algas marinas en los países em desarrollo. FAO Circular de Pesca No. 968. Roma, FAO. 30p.

Mchugh DJ. 2003. A guide to the seaweed industry. Fao Fisheries Tech. Paper 105p.

Navarro NP.; Mansilla A. Plastino EM. 2010. Iridaea cordata (Gigartinales, Rhodophyta): responses to artificial UVB radiation. J. Appl. Phycol. 22: 385-394.

Navarro N. 2011. Efeitos da radiação ultravioleta solar em algas de importância econômica da região subantártica do Chile durante a primavera. Tese de doutorado. Instituto de Biociências. Universidade de São Paulo. São Paulo. 210p.

Notoya M.; Nagashima M.; Aruga Y. 1994. Influence of light intensity and temperature on callus development in young sporophytes of three species of Laminariales (Phaeophyta). J. Mar. Biotechnol. 2: 2-15.

Oliveira EC.; Sazima IP. 1973. Estudos sobre a biologia de algas agarofitas - Recolonização, brotamento e fenologia em populações de Pterocladia capillacea (Rhodophyta, Gelidiaceae). Bol. Zool. Biol. Mar. 30: 677-690.

Oliveira EC.; Plastino EM. 1984. The life-history of Gracilaria (Rhodophyta) from Brazil. Japan. J. Phycol. 32: 203-208.

Oliveira EC.; Berchez FS. 1993. Resource biology of Pterocladia capillacea populations In Brazil. Hydrobiologia 85: 255-262. 
Oliveira EC.; Saito RM.; Neto JFS.; Garofalo GMC. 1996. Temporal and spatial variation in agar from a population of Pterocladia capillacea (Gelidiales, Rhodophyta) from Brazil. Hydrobiologia. 326/327: 501-504.

Orduña-Rojas J.; Robledo D. 1999. Effects of irradiance and temperature on the release and growth of carpospores from Gracilaria cornea J. Agardh (Gracilariales, Rhodophyta). Bot. Mar. 42: 315-319.

Oyamada C.; Kaneniwa M.; Ebitani K.; Murata M.; Ishihara K. 2008. Mycosporine-like amino- acids extracted from scallop (Patinopecten yessoensis) ovaries: UV protection and growth stimulation activities on human cells. Mar. Biotechnol. 10: 141-150.

Pangestuti R.; Kim SK. 2011. Biological activities and health benefit effects of natural pigments derived from marine algae. J. Funct. Foods 3: 255-266.

Penniman CA.; Mathieson AC.; Penniman CE. 1986. Reproductive phenology and growth of Gracilaria tikvahiae Mclachlan (Gigartinales, Rhodophyta) in the Great Bay Estuary, New Hampshire. Bot. Mar. 29: 147-154.

Petti R.; Plastino EM. 2012. Estudo comparativo de dois processos de esterilização de água do mar para preparação de meios de cultura de algas em laboratório. In: xiv congresso brasileiro de ficologia. Disponível em <Http://Www.Sbfic.Org.Br/Cbfic2012/Ocs2.3.4/Index.Php/Xivcbfic/Congresso/Paper/Vi ew/340> Acesso em 14/06/2016.

Pujol CA.; Ray S.; Damonte EB. 2010. Antiviral activity against dengue virus of diverse classes of algal sulfated polysaccharides. Int. J. Biol. Macromol. 51: 412-416.

Prajapati VD.; Maheriya PM.; Jani GK.; Solanki HK.2014. Carrageenan: a natural seaweed polysaccharide and its applications. Carbohyd. Polymers 105: 97-112.

Qi H.; Zhang Q.; Zhao T.; Chen R.; Zhang H.; Niu X.; Li Z. 2005. Antioxidant activity of different sulfate content derivates of polysaccharide extracted from Ulva pertusa (Chlorophyta) in vitro. Int. J. Biol. Macromol. 37:195-199.

Quirós-Rodríguez JA.; Arias-Ríos JE.; Ruiz R. 2010. Estructura de las comunidades macroalgales asociadas al litoral rocoso del departamento de Córdoba, Colombia. Caldasia 32: 339-354.

Ramlov F. 2010. Variação sazonal dos carotenóides e compostos fenólicos e estudos fisiológicos em diferentes estádios reprodutivos de Gracilaria domingensis (Kuttz.) 
Sonder ex Dickie (Gracilariales, Rhodophyta). Tese de doutorado. Instituto de Botânica da Secretaria de Estado do Meio Ambiente. São Paulo. 150p.

Ramus J.; Rosenberg G. 1980. Diurnal photosynthetic performance of seaweeds measured under natural conditions. Mar. Biol. 56: 21-28.

Raposo MFJ.; Morais RMSC.; Morais AMB. 2013. Health applications of bioactive compounds from marine microalgae. Life Sci. 93: 479-486.

Rezende FM. 2013. Efeito da atmosfera enriquecida com CO2 em mudas de Psidium guajava L. cv. Pedro Sato. Dissertação de mestrado. Instituto de Biociências. Universidade de São Paulo. São Paulo. 119 p.

Rodrıguez-Ezpeleta N.; Brinkmann H.; Burey SC.; Roure B.; Burger G.; LöFfelhardt W.; Bohnert HJ.; Philippe H.; Lang BF. 2005. Monophyly of primary photosynthetic eukaryotes: green plants, red algae, and glaucophytes. Curr. Biol. 15: 1325-1330.

Rocha FD.; Pereira RC.; Kaplan MAC.; Teixeira V. 2007. Produtos naturais de algas marinhas e seu potencial antioxidante. Rev. Bras. Farmacol. 17:631-639.

Rohácek K. 2002. Chlorophyll fluorescence parameters: the definitions, photosynthetic meaning, and mutual relationships. Photosynthetica Res. 401: 13-29.

Roleda MY.; Nyberg CD.; Wulff A. 2012. UVR defense mechanisms in eurytopic and invasive Gracilaria vermiculophylla (Gracilariales, Rhodophyta). Plant Physiol. 146: 205-216.

Rufino M.; Alves R. 2007. Metodologia científica: determinação da atividade antioxidante total em frutas pela captura do radical livre DPPH. Retrieved From <Http://Agris.Fao.Org/Agrissearch/Search.Do?F=2012/Br/Br2012102700027.Xml;Br200 71426953 $\geq$ Embrapa 3-6p.

Sampaio MM.; Cruz A. 2014. Macro e microalgas como fonte natural de pigmentos. Soc. Port. Biotecnol. 22-23.

Santelices B.; Hommersand M. 1997. Pterocladiella, a new genus in the Gelidiaceae (Gelidiales, Rhodophyta). Phycologia. 36: 114-119.

Santelices B. 1998. Taxonomic review of the species of Pterocladia (Gelidiales, Rhodophyta). J. Appl Phycol. 10: 237-252.

Saunders GW. 2005. Applying DNA barcoding to red macroalgae: a preliminary appraisal holds promise for future applications. Philos. Trans. R. Soc. Lond. B. Biol. Sci. 360:1879-1888. 
Saunders GW.; Moore TE. 2013. Refinements for the amplification and sequencing of red algal DNA barcode and RedToL phylogenetic markers: a summary of current primers, profiles and strategies. Algae 28: 31-43.

Sekmokienė D.; Liutkevičius A.; Malakauskas M. 2007. Functional food and it's ingredients. Vet. Zoo. 37:72-78.

Serra DR. 2013. Resposta de Gracilariopsis tenuifrons (Gracilariales - Rhodophyta) a estímulos de irradiância in vitro. Dissertação de mestrado. Instituto de Biociências, Universidade de São Paulo, São Paulo. 97p.

Singleton Vl.; Rossi JA. 1965. Colorimetry of total phenolics with phosphomolybdic phosphotungstic acid reagents. Am. J. Enol. Viticult. 16: 144-158.

Sinha RP.; Singh SP.; Häder D.-P. 2007. Database on mycosporines and mycosporine-like aminoacids (MAAs) in fungi, cyanobacteria, macroalgae, phytoplankton and animals. $J$. Photochem. Photobiol. B. 89: 29-35.

Singh SP.; Kumari S.; Rastogi RP.; Singh KL.; Sinha RP. 2008. Mycosporine-like amino acids (MAAs): Chemical structure, biosynthesis and significance as UVabsorbing/screening compounds. Indian J. Exp. Biol. 46: 7-17.

Sivalingam PM.; Ikawa T.; Yokohama Y.; Nisizawa K. 1974. Distribution of a 334 UVabsorbing-substance in algae, with special regard of its possible physiological roles. Bot. Mar. 17: 23-29.

Sudatti DB.; Fujii MT.; Rodrigues SV.; Turra A.; Pereira RC. 2011. Effects of abiotic factors on growth and chemical defenses in cultivated clones of Laurencia dendroidea J. Agardh (Ceramiales, Rhodophyta). Mar. Biol. 1439-1446p.

Schmidt EC.; Scariot LA.; Rover T.; Bouzon ZL. 2009. Changes in ultrastructure and histochemistry of two red macroalgae strains of Kappaphycus alvarezii Rhodophyta, Gigarti- nales, as a consequence of ultraviolet B radiation exposure. Micron 40: 860-869.

Schreiber U.; Schliwa U.; Bilger W. 1986. Continuous recording of photochemical and nonphotochemical chlorophyll fluorescence quenching with a new type of modulation fluorometer. Photosynthetica Res. 10: 51-62.

Schreiber U.; Neubauer C. 1990. 02-dependent electron flow, membrane energization and the mechanism of non-photochemical quenching of chlorophyll fluorescence. Photosynthetica Res. 25:279-293. 
Schwachtje J.; Baldwin IT. 2008. Why does herbivore attack reconfigure primary metabolism. Plant Physiol. 146: 845-851.

Shick JM.; Dunlap WC. 2002. Mycosporine-like amino acids and related gadusols: biosynthesis, accumulation and uv-protective functions in aquatic organisms. Annu. Rev. Physiol. 64: 223-262.

Schmidt EC.; Felix De L.; Marthiellen R.; Polo LK.; Kreusch MG.; Pereira DT.; Costa GB.; Simioni C.; De P. Martins R.; Latini A.; Chow F.; Ramlov F.; Pereira A.; Maraschin M.; Ouriques LC.; Steiner N.; Bouzon ZL.2015. Influence of cadmium and salinity in the red alga Pterocladiella capillacea: cell morphology, photosynthetic performance and antioxidant systems. Rev. Bras. Bot.1:1-13.

Scrosati R. 2002. Morphological plasticity and apparent loss of apical dominance following the natural loss of the main apex in Pterocladiella capillacea (Rhodophyta, Gelidiales) fronds. Phycologia. 41: 96-98.

Snedecor GW. 1966. Métodos estatísticos aplicados a la investigatioll agricola ebiológica. México, Compan. Edit. Contin. S.A. 626p.

Stewart JG. 1983. Vegetative growth rates of Pterocladia capillacea (Gelidiaceae, Rhodophyta). Bot. Mar. 27: 85-94.

Tandon M.; Thirumeignanam D.; Rai SN. 2008. Ferric reducing antioxidant power (FRAP) Assay. Dairy Catt. Nutrit. Div. 0-2.

Tadolini B.; Juliano C.; Piu L.; Franconi L.; Cabrini, R. 2000. Resveratrol inhibition of lipid peroxidation. Free Radic. Res. 33 105-114.

Takano S.; Uemura D.; Hirata Y. 1979. Isolation and structure of a $334 \mathrm{~nm}$ UV absorbing substance, porphyra-334 from the red algae Porphyra tenera Kjellman. Chem. Lett. 26: 419-420.

Tala F. 2003. Fenologia e ecofisiologia das macroalgas Porphyra spp. (Bangiales, Rhodophyta) e Lessonia spp. (Laminariales, Phaeophyceae) na costa norte e central do chile: variações latitudinais e sazonais. Tese de doutorado. Instituto de Biociências. Universidade de São Paulo. São Paulo. 233p.

Talarico L.; Rascio N.; Dalla Vecchia F.; Maranzana G. 1998. Some observations on phycobilisomes of Pterocladiella capillacea (Gelidiaceae, Rhodophyta). Plant Biosyst. 132: 87-96. 
Tamura K.; Peterson D.; Peterson N.; Stecher G.; Nei M.; Kumar S. 2011. MEGA: molecular evolutionary genetics analysis using maximum likelihood, evolutionary distance, and maximum parsimony methods. Mol. Biol. Evol. 28: 2731-9.

Taylor WR. 1960. Marine algae of the eastern tropical and subtropical coasts of the Americas. University of Michigan Studies: Scientific Series. Univ. of Michigan Press. 21p.

Torres BP. 2012. Análise de pigmentos fotossintetizantes e substâncias fenólicas em Gracilariopsis tenuifrons (c. J. Bird \& e. C. Oliveira) frederico \& hommersand em diferentes intensidades de luz. Dissertação de mestrado. Instituto de Biociências. Universidade de São Paulo. São Paulo. 104p.

Torres BP; Chow F.; Santos DYAC. 2014. Growth and photosynthetic pigments of Gracilariopsis tenuifrons (Rhodophyta, gracilariaceae) under high light in vitro culture. $J$. Appl. Phycol. 27: 1243-1251.

Torres BP; Chow F.; Ferreira M.; Santos DYAC. 2015. Effects of stressing high par on mycosporine-like amino acids in the red alga Gracilariopsis tenuifrons (Gracilariales, Rhodophyta). Plant Med. 1-6.

Turpin DH. 1991. Effects of inorganic $\mathrm{n}$ availability on algal photosynthesis and carbon metabolism. J. Phycol. 27: 14-20.

Tripodi G. 1971. Some observations on the ultrastructure of the red alga Pterocladia capillacea (Gmel.) Born. et Thur. J. Submicr. Cytol. 3: 63-70.

Ugadim Y. 1985. Estudos taxonomicos de Gelidium e Pterocladia (Gelidiaceae, Nemaliales, Rhodophyta) do Brasil. Tese de doutorado. Instituto de Biociências. Universidade de São Paulo. São Paulo. 218p.

Urrea-Victoria V.; Pires JS.; Torres PB.; Dos Santos DYAC.; Chow F. 2016. Ensaio antioxidante em microplaca do poder de redução do ferro (FRAP) para extratos de algas. Instituto de Biociências, Universidade de São Paulo. ISBN 978-85-85658-62-5 1-6.

Ursi S.; Plastino EM. 2001. Crescimento in vitro de linhagens de coloração vermelha e marrom-esverdeada clara de Gracilaria sp. (Gracilariales, Rhodophyta) em dois meios de cultura: análise de diferentes estádios reprodutivos. Rev. Bras. Bot. 24: 587-594.

Ursi S.;,Pedersén M.; Plastino EM.; Snoeijs P. 2003. Intraspecific variation of photosynthesis, respiration and photoprotective carotenoids in Gracilaria birdiae (Gracilariales: Rhodophyta). Mar. Biol. 142:997-1007. 
Ursi S. 2005. Diversidade intraespecífica em Gracilaria birdiae (Gracilariales, Rhodophyta): crescimento, fotossíntese, pigmentos, polissacarídeos e genes da ficoeritrina de linhagens selvagens e variantes. Tese de Doutorado. Instituto de Biociências. Universidade de São Paulo. São Paulo. 121p.

Ursi S.; Costa VL.; Hayashi L.; Pereira RTL.; Paula EJ.; Plastino EM. 2013. Intraspecific variation in Gracilaria birdiae (Gracilariales, Rhodophyta): growth, and agar yield and quality of color strains under aquaculture. Bot. Mar. 56:241-248.

Vianna SC.; Sanquetta RC. 2012. Mudanças climáticas e o fitoplâncton marinho: uma revisão. Encicl. Bios. 8: 1883-1901.

Vidotti EC.; Rollemberg MCE. 2004. Algas: da economia nos ambientes aquáticos à biorremediação e à química analítica. Quím. Nova 27: 139-145.

Wanderley A. 2009. Influência da disponibilidade de nitrato sobre crescimento, atividade da nitrato redutase, composição química e captação de nitrato e fosfato em gracilariopsis tenuifrons (Gracilariales, Rhodophyta). Dissertação de mestrado. Instituto de Biociências. Universidade de São Paulo. São Paulo. 140p.

Waterman PG.; Mole S. 1994. Analysis of phenolic plant metabolites. Blackwell Sci. Public.1-7.

Wijesekara I.; Pangestuti R.; Kim SK. 2011. Biological activities and potential health benefits of sulfated polysaccharides derived from marine algae. Carbohyd. Polymers 84:14-21.

Yang H.; Dong Y.; Du H.; Shi H; Peng Y.; Li X. 2011. Antioxidant compounds from propolis collected in anhui, China. Molecules 16: 3444-55.

Yokoya NS.; Oliveira EC. 1992. Effects of salinity on the growth rate, morphology and water content of some Brazilian red algae of economic importance. Ciênc. Mar. Méxic. 18:4964.

Yokoya NS.; Handro W. 1996. Effects of auxins and citokinin on tissue culture of Grateloupia dichotoma (Gigartinales, Rhodophyta). Hydrobiologia 326/327: 393-400.

Yokoya NS.; Plastino EM.; Artel R. 2003. Physiological responses and pigment characterization of two colour strains of the carrageenophyte Hypnea musciformis (Rhodophyta). In: A.R.O. Chapman, R.J. Anderson, V.J. Vreelnad \& J.R. Dawison (eds.). Proceedings of the XVIIth International Seaweed Symposium, Oxford University Press, New York, 425-433. 
Yoon HS.; Müller KM.; Sheat RG.; Ott FD.; Bhattacharya D. 2006. Defining the major lineages od red algae (Rhodophyta). J. Phycol. 42: 482-492.

Yoshida T.; Sivalingam PM. 1969. UV-absorbing substance in red alga, Porphyra yezoensis Ueda. J. Tokyo Univ. Fish. 2: 427-434.

Yoshida K.; Terashima I.; Noguchi K. 2011. How and why does mitochondrial respiratory chain respond to light? Plant Signal Behav. 6: 864-866.

Yuan YV.; Westcott ND.; Huc Ch.; Kitts DD. Mycosporine-like amino acid composition of the edible red alga, Palmaria palmata (dulse) harvested from the west and east coasts of Grand Manan Island, New Brunswick. Food Chem. 112: 321-328.

Zhou G.; Sun Y.; Xin H.; Zhang Y.; Li Z.; Xu Z. 2004. In vivo antitumor and immunomodulation activities of different molecular weight lambda-carrageenans from Chondrus ocellatus. Pharmacol. Res. 50: 47-53. 


\section{Capítulo I}

\section{Fotosensibilidade e desempenho fisiológico de Pterocladiella capillacea \\ (Rhodophyta, Gelidiales): crescimento, fotossíntese, teor de CHN e conteúdo de pigmentos e proteínas}

\section{Photosensitivity and physiological performance of Pterocladiella capillacea (Rhodophyta, Gelidiales): growth, photosynthesis, CHN levels, and pigment and protein contents}

\section{Resumo}

As macroalgas marinhas precisam ser aptas a sobreviverem em condições de altas e baixas irradiâncias, sem haver prejuízo para realização da fotossíntese ou de outros processos vitais. Altas irradiâncias podem afetar significativamente o metabolismo geral das macroalgas, no entanto, podem também estimular a biossíntese de certos compostos fotoprotetores de interesse biotecnológico, como pigmentos e proteínas. Medidas de crescimento e fotossíntese têm sido geralmente relacionadas com produtividade algácea, de forma a fornecer importantes informações sobre a resiliência dos organismos frente a condições desfavoráveis como alta irradiância. O objetivo deste estudo foi analisar a fotosensibilidade de Pterocladiella capillacea (Rhodophyta, Gelidiales) submetida a duas irradiâncias: (a) $60 \pm 5 \mu$ mol fótons.m ${ }^{-}$ ${ }^{2} \cdot \mathrm{s}^{-1}$ (controle) e (b) $300 \pm 5 \mu \mathrm{mol}$ fótons. $\mathrm{m}^{-2} \cdot \mathrm{s}^{-1}$ mediante análise do crescimento, fotossíntese, CHN, pigmentos e proteínas solúveis. A taxa de crescimento apresentou aumento significativo em $300 \mu \mathrm{mol}$ fótons. $\mathrm{m}^{-2}$. $\mathrm{s}^{-1}$, com redução na dissipação fotoquímica, indicando resiliência na tolerância a essa condição. Em relação à dissipação não fotoquímica não regulada, a dissipação de calor sem gasto de energia foi maior em $300 \mu \mathrm{mol}$ fótons. $\mathrm{m}^{-2} . \mathrm{s}^{-1}$ do que $60 \mu \mathrm{mol}$ fótons. $\mathrm{m}^{-2} . \mathrm{s}^{-1}$, o que poderia representar que $P$. capillacea, apesar de ser uma alga de sombra, possui mecanismos eficientes para a dissipação por calor. Por sua vez, $P$. capillacea apresentou tendência de menores valores de ETR $_{\text {máx }}$ com o aumento da irradiância. Pterocladiella capillacea foi altamente eficiente em fotoaclimatação e requisitou pouca quantidade de luz para crescer e realizar processos fotoquímicos. 


\begin{abstract}
Marine macroalgae must be able to survive in conditions of high and low light intensities, with no damage to perform photosynthesis or other vital processes. High irradiance can significantly affect the general metabolism of macroalgae, however, it can also estimulate the biosynthesis of certain photoprotective compounds of biotechnological interest, such as pigments and proteins. Growth and photosynthesis data have generally been related to algal productivity in order to provide important information about the resilience of the species against adverse conditions like high irradiance. The aim of this study was to analyze the photosensitivity of Pterocladiella capillacea (Rhodophyta, Gelidiales) under two light intensities: (a) $60 \pm 560 \mu \mathrm{mol}$ photons. $\mathrm{m}^{-2} \cdot \mathrm{s}^{-1}$ (control) and (b) $300 \pm 5 \mu \mathrm{mol}$ photons. $\mathrm{m}^{-2} \cdot \mathrm{s}^{-1}$ by analysing growth, photosynthesis, $\mathrm{CHN}$, pigments and soluble proteins. The growth rate increased significantly at $300 \mu \mathrm{mol}$ fótons. $\mathrm{m}^{-2} \cdot \mathrm{s}^{-1}$ with slight decrease in photochemical quenching, indicating tolerance resilience for this condition. Regarding non-regulated nonphotochemical quenching, the heat dissipation without energy cost was higher in $300 \mu \mathrm{mol}$ photons. $\mathrm{m}^{-2} . \mathrm{s}^{-1}$ than $60 \mu \mathrm{mol}$ photons. $\mathrm{m}^{-2} . \mathrm{s}^{-1}$, which could represent that $P$. capillacea, despite being a shadow alga has efficient mechanisms for heat dissipation. In turn, $P$. capillacea ended to lower $\mathrm{ETR}_{\text {máx }}$ values with increasing irradiance. Pterocladiella capillacea was highly efficient in photoacclimation and needed a small amount of light to grow and perform photochemical processes.
\end{abstract}




\section{Introdução}

A energia associada à radiação ultravioleta (UVR) e à radiação fotossinteticamente ativa (PAR) pauta a capacidade fotossintetizante de uma macroalga e, frequentemente, está associada a processos de fotosensibilidade, fototolerância, fotoinibição e fotodano quando excede a viabilidade fotoquímica ou de dissipação de energia do organismo. A fotoinibição ocorre quando a quantidade de luz disponível para a fotossíntese é excessiva, ou seja, quando a irradiância é maior que a capacidade de aclimatação, causando a redução da atividade fotossintetizante (Asada, 1994; Takahashi \& Murata, 2008). O fotodano é geralmente associado a estresse oxidativo através da produção e acúmulo de espécies reativas de oxigênio (EROs), espécies reativas de nitrogênio (ERNs) e seus derivados, que ocasionam a clivagem específica da proteína D1 (componente do fotossistema II), ativando vários mecanismos de defesa, como a produção de compostos antioxidantes (Nishiyama et al., 2004) e a atividade de enzimas antioxidantes específicas (Lee \& Shiu, 2009; Santos et al., 2012; Wang et al., 2012).

As algas são capazes de se aclimatar quando submetidas a variações na intensidade da irradiância. Algas aclimatadas a altas intensidades luminosas, algas de sol, podem apresentar altas taxas de fotossíntese máxima, baixa eficiência fotossintetizante e altos valores de irradiância de saturação, além de baixo conteúdo de clorofila e altos teores a curto prazo de pigmentos acessórios, como carotenoides e ficobiliproteínas (Falkowski, 1980; Grobbelaar \& Kurano, 2003). Por outro lado, algas aclimatadas a baixas irradiâncias, algas de sombra, apresentam baixas taxas de fotossíntese máxima, altos valores de eficiência fotossintetizante e baixos valores de irradiância de saturação, com altas concentrações de pigmentos (Falkowski, 1980; Grobbelaar \& Kurano, 2003).

Em ambientes naturais, onde as variações na intensidade luminosa possuem elevada amplitude, muitas algas parecem aclimatar os complexos coletores de luz para distribuir a energia de excitação entre os fotossistemas, a fim de evitar o fotodano (Falkowski, 1980; Franklin et al., 2003). Dessa forma, regulam pequenas mudanças na captação ou dissipação da irradiância, uma vez que, o aumento excessivo da irradiância leva à produção de espécies reativas, que podem causar danos fotooxidativos no PSII (Hideg et al., 1994; Hanelt et al., 2006). Os pigmentos acessórios também aumentam com a diminuição da intensidade luminosa, geralmente na mesma intensidade que a clorofila $a$ (Dring, 1990; Copertino et al., 2006). Por outro lado, altas intensidades de radiação solar podem causar fotoinibição ou ainda 
morte celular devido à incapacidade que algumas algas apresentam em ajustar a composição ou concentração de pigmentos a altas irradiâncias (Hanelt et al., 2006).

Em períodos prolongados sob alta incidência de luz, a autofluorescência da macroalga tende a aumentar, nessas condições as ficobiliproteínas são os pigmentos mais sensíveis à luz, sendo os primeiros a se degradarem, seguidos então pelos carotenoides e pela clorofila $a$ (Donkor \& Hader, 1996; Beach et al., 2000).

De forma geral, a capacidade de utilização da energia luminosa serve como um sensor para regular a concentração adequada de pigmentos para manter um balanço entre captura de energia de excitação, fotoquímica e demanda energética para crescimento (MacIntyre et al., 2000). Portanto, as macroalgas marinhas precisam ser capazes de absorver luz em situações de baixa e alta irradiância sem que haja o comprometimento do processo fotossintetizante (Franklin \& Larkum, 1997; Necchi, 2005). Por outro lado, a degradação de pigmentos disponibiliza componentes orgânicos e inorgânicos (ex. nitrogênio) que podem ser remanejados para a formação de outros compostos para manutenção e defesa das células (MacIntyre et al., 2000).

Além dos pigmentos, outros componentes celulares são afetados pela intensidade luminosa, por exemplo, o teor de proteínas solúveis totais. O incremento de proteínas geralmente é inversamente correlacionado com a intensidade luminosa, devido à menor disponibilidade de nutrientes no meio (Perfeto et al., 2004). Os conteúdos de carbono e nitrogênio, são igualmente influenciados pela luminosidade, e sua variação celular permite avaliar o incremento de matéria orgância e estado nutriconal de macroalgas. Altas irradiâncias podem provocar um déficit nutricional em macroalgas e, em resposta, estes organismos podem utilizar reservas de carbono como amido (He et al., 2002; Nyvall-Cóllen et al., 2004).

Assim, considerandos as infomações descritas, este estudo teve por objetivo avaliar a fotosensibilidade de Pterocladiella capillacea (S.G. Gmelin) Santelices \& Hommersand (Rhodophyta, Gelidiales) e os mecanismos de tolerância de $P$. capillacea submetida às intensidades PAR de $60 \mu \mathrm{mol}$ fótons. $\mathrm{m}^{-2} . \mathrm{s}^{-1}$ e $300 \mu \mathrm{mol}$ fótons. $\mathrm{m}^{-2} . \mathrm{s}^{-1}$, mediante estudos de taxa de crescimento, desempenho fotossintetizante, conteúdo pigmentar (ficobiliproteínas, clorofila $a$ e carotenoides), proteínas solúveis totais e conteúdos de carbono, hidrogênio e nitrogênio. 


\section{Material e métodos}

Pterocladiella capillacea foi coletada na região entremarés do costão rochoso da Praia

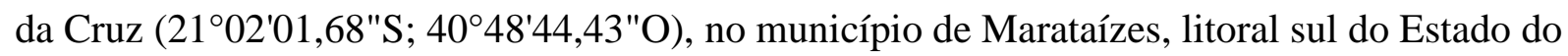
Espírito Santo, Brasil, e mantidas em cultivo no Laboratório de Algas Marinhas "Édison José de Paula" da Universidade de São Paulo. Porções distais entre 8 a $10 \mathrm{~cm}$ de comprimento foram aclimatadas por uma semana na proporção de $3 \mathrm{~g}$ de massa fresca (MF) para cada $1 \mathrm{~L}$ de meio de cultivo em água do mar esterilizada, 32 ups, enriquecida com solução de nutriente de von Stosch (VS; Ursi \& Plastino 2001, modificada de Edwards, 1970) a uma concentração de $100 \%, 25 \pm 1^{\circ} \mathrm{C}, 60 \pm 5 \mu \mathrm{mol}$ fótons. $\mathrm{m}^{-2} \cdot \mathrm{s}^{-1}$, fotoperíodo de $14 \mathrm{~h}$ de luz e $10 \mathrm{~h}$ de escuro e aeração em períodos intermitentes de 30 min ligado e 30 min desligado. Após a aclimatação, o experimento foi realizado por um período de oito dias nas mesmas condições descritas acima sob duas condições de irradiância: (a) $60 \pm 5 \mu \mathrm{mol}$ fótons. $\mathrm{m}^{-2} \cdot \mathrm{s}^{-1}$ (controle) e (b) $300 \pm$ $5 \mu \mathrm{mol}$ fótons.m $\mathrm{m}^{-2} \cdot \mathrm{s}^{-1}$, fornecida por lâmpadas fluorescentes do tipo "luz do dia" (Phillips). Particularmente, o oitavo dia representa tratamento após $24 \mathrm{~h}$ de enriquecimento com VS 100\%, com o objetivo de avaliar a resiliência de recuperação da espécie.

Foi realizada identificação taxonômica através de análise de caracteres morfológicos e molecular mediante a técnica de "DNA barcode". Os caracteres morfológicos foram avaliados seguindo os trabalhos de Santelices \& Hommersand (1997), Santelices (1998), Millar \& Freshwater (2005) e Iha (2014).

A avaliação molecular foi realizada extraíndo o DNA de $50 \mathrm{mg}$ MF de diferentes indivíduos de $P$. capillacea $(\mathrm{n}=4)$ com o kit "NucleoSpin Plant II" (Macherel-Nadel, EUA). Após a extração, foi feita a reação em cadeia da polimerase (PCR) do marcador molecular coxl. O produto da PCR foi purificado e sequenciado com o kit "BigDye Terminator Cycle Sequencing Ready Reaction" (Applied Biosystems, EUA). As sequências obtidas foram alinhadas usando o programa BioEdit 7.0.4.1 e comparadas com as sequências do GenBank. As sequências dos "DNA barcodes", COI-5P do marcador coxl de todas as amostras, foram alinhadas em uma matriz no programa MEGA 7 e realizada uma árvore de agrupamento por máxima verossimilhança.

A taxa de crescimento, o desempenho fotossintetizante e os conteúdos de CHN, pigmentos e proteínas solúveis totais foram avaliados nos dias $0,1,3,5,7$ e 8 . 
A taxa de crescimento (TC) foi calculada de acordo com Penniman et al. (1986), seguindo a fórmula: TC $\left(\% \cdot \operatorname{dia}^{-1}\right)=\left((\mathrm{Mf} / \mathrm{Mi})^{1 / \mathrm{t}}-1\right) \times 100$; onde, $\mathrm{Mf}=$ massa úmida final $(\mathrm{g})$, $\mathrm{Mi}=$ massa úmida inicial $(\mathrm{g}), \mathrm{t}=$ tempo (dias).

A fotossíntese foi avaliada mediante análises do desempenho fotossintetizante medindo a fluorescência in vivo da clorofila $a$ do PSII, utilizando um fluorômetro de pulso de amplitude modulada PAM-2500 (Walz, Alemanha). Foram avaliados os parâmetros: rendimento quântico ótimo (Fv/Fm) após 15 min de aclimatação no escuro (Schreiber et al., 1986), rendimento quântico efetivo (Y(II); Schreiber \& Neubaer (1990)), dissipação fotoquímica (Y(PSII)), dissipação não fotoquímica não regulada (Y(NO)) e dissipação não fotoquímica regulada (Y(NPQ)) (Rohácek, 2002). A taxa de transporte de elétrons (ETR) foi estimada mediante a exposição do material a oito intensidades crescentes de PAR $(0,24,61$, 108, 186, 456, 752 e $1.024 \mu \mathrm{mol}$ fótons. $\left.\mathrm{m}^{-2} \cdot \mathrm{s}^{-1}\right)$, curva ETR-PAR, e calculado como ETR = Y(II) x PAR x A x 0,15; sendo A a absorptância dos talos (Mercado et al. 1996). A absorptância foi medida de acordo com a fórmula $A=1$ - IF/Io, sendo Io a irradiância inicial que incide por uma fonte de luz fixa e IF a irradiância final transmitida através do material algáceo (Ramus \& Rosenberg, 1980). e 0,15 a fração de clorofila $a$ associada ao PSII para algas vermelhas (Grzymski et al., 1997; Figueroa et al., 2003a). A partir das curvas de ETRPAR foram determinados o ETR máximo $\left(\mathrm{ETR}_{\text {máx }}\right.$ em intensidade PAR de saturação), eficiência fotossintetizante $(\alpha)$ e intensidade de saturação luminosa (Ik) (Maxwell \& Johnson, 2000), segundo o ajuste de Jassby \& Platt (1976).

O teor de ficobiliproteínas e proteínas solúveis totais foram avaliados a partir de amostras de $70 \mathrm{mg}$ MF extraídas em tampão fosfato 0,05 M gelado (pH 5,5) e analisadas em espectrofotômetro UV-visível (Epoch Biotek, EUA). As concentraçõs de ficobiliproteínas ( $\mu \mathrm{g} . \mathrm{g} \mathrm{MF}^{-1}$ ) foram calculdas a partir de suas absorbâncias segundo as fórmulas: $\mathrm{FE}$ $($ ficoeritrina $)=(155,8 \times$ A498 $)-(40 \times$ A614 $)-(10,5 \times$ A652 $), F C$ (ficocianina $)=(151,1 \times$ A614) - (99,1 x A652) e ALC (aloficocianina) $=(181,3 \times$ A652) - (22,3 x A614) de acordo com Kursar et al. (1983); onde A representa a absorbância no respectivo comprimento de onda.

A concentração de proteínas solúveis totais foi estimada pelo método de Bradford (1976) a partir do mesmo extrato das ficobiliproteínas, utilizando o reagente para ensaio proteico Bio-Rad (EUA) e soro de albumina de bovino (BSA) como padrão. Diferentes curvas padrões de BSA foram construídas: para os tempos t0 e t1 ( $\left.y=0,2107 x ; R^{2}=0,9779\right)$, para $\mathrm{t} 3$ 
e t5 $\left(y=0,1535 x ; R^{2}=0,9911\right)$ e para t7 e t8 $\left(y=0,1816 x ; R^{2}=0,9655\right)($ ver detalhes em Anexo II).

As análises dos carotenoides e da clorofila $a$ seguiram o método descrito por Wanderley (2009). O material sedimentado obtido após a extração das ficobiliproteínas foi ressuspendido em $1 \mathrm{~mL}$ de metanol e extraído por $3 \mathrm{~h}$ a $4^{\circ} \mathrm{C}$ e protegido da luz. $\mathrm{O}$ sobrenadante foi analisado em espectrofotômetro UV-visível (Epoch Biotek, EUA) e as concentrações de clorofila $a(\mathrm{Clh} a)$ e carotenoides totais (Car) foram calculadas a partir de suas absorbâncias com base nas fórmulas: $\mathrm{Clh} a\left(\mu \mathrm{g} \cdot \mathrm{g} \mathrm{MF}^{-1}\right)=(12,61$ x A664) e Car $(\mu \mathrm{g} . \mathrm{g}$ $\left.\mathrm{MF}^{-1}\right)=(1000 \times \mathrm{A} 470$ - 1,63 x Chla) / 221; modificado de Lichtenthaler \& Buschmann (2001); onde A representa a absorbância no respectivo comprimento de onda.

A quantificação dos elementos carbono $(\mathrm{C})$, hidrogênio $(\mathrm{H})$ e nitrogênio $(\mathrm{N})(\mathrm{CHN})$ foi realizada na Central Analítica do Instituto de Química da USP, com o uso de um analisador de composição elementar CNH Perkin- Elmer, modelo 2400 (EUA). O conteúdo total de $\mathrm{C}, \mathrm{N}$ e $\mathrm{H}$ das amostras foi calculado de acordo com o percentual de cada elemento e padronizado pela massa seca (MS) da alga. Os resultados foram expressos em mg.g $\mathrm{MS}^{-1}$.

Os extratos tamponados e metanólicos obtidos na extração de pigmentos foram analisados em espectrofotômetro de microplacas nanodrop UV-visível (Epoch Biotek, EUA), no intervalo de 240 a $400 \mathrm{~nm}$, com o intuito de verificar a presença de compostos que absorvem dentro do espectro UV.

Todos os parâmetros foram estudados com cinco repetições para cada tratamento. Os resultados obtidos foram analisados estatisticamente com o programa Statistica 12 e testados quanto à normalidade e homocedasticidade $(\mathrm{p}<0,05)$. A significância das médias foi analisada dentro de um intervalo de confiança de 95\% ( $\mathrm{p}<0,05)$, com ANOVA bifatorial e teste post-hoc de comparação múltipla de Newman-Keuls (ver detalhes em Anexo I; Tabelas AI-1-6). Com conjunto dos dados foi realizada uma análise de componentes principais (PCA) com o auxílio do programa Past.

\section{Resultados}

\subsection{Identificação taxonômica}

A Figura 7A mostra o hábito geral de um indivíduo de $P$. capillacea, evidenciando padrão de ramificação essencialmente pinada a bipinada nos dois terços superiores dos ramos eretos, dando aspecto triangular ao conjunto de eixos. A Figura 7B destaca a presença de 
estiquídios com numerosos tetrasporângios divididos tetraedricamente, do tipo ovoides a globoides. A Figura 7C evidencia, na sua extremidade a presença de uma célula apical central, que corrobora um talo organizado internamente de maneira uniaxial. Em seção transversal, a Figura 7D apresenta um córtex com poucas células fortemente pigmentadas e uma região medular com células poligonais e filamentos intercalares.

A Figura 8 apresenta a filogenia de $P$. capillacea por máxima verossimilhança para a região COI-5P do marcador coxl. Analisando 18 sequências de nucleótidos, incluindo as quatro sequências alvo deste estudo, o cladograma mostra que $P$. capillacea agrupou com sequências da mesma espécie, com porcentagens da taxa de 62 e 100\%. As posições contendo lacunas e dados em falta foram eliminados. Houve um total de 624 posições no conjunto de dados final.
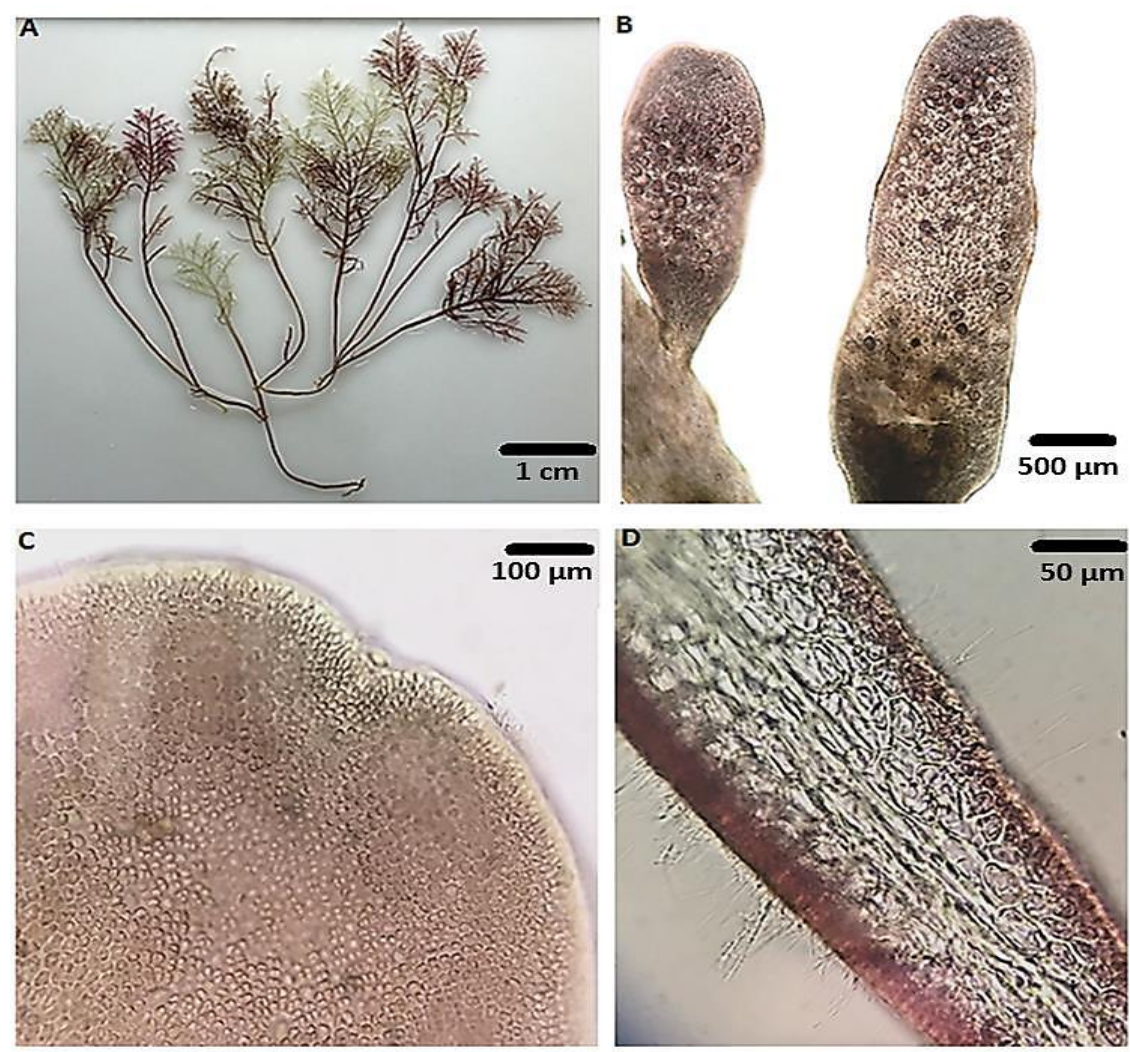

Figura 7. Caracteres morfológicos utilizados para a identificação taxonômica de Pterocladiella capillacea. (A) aspecto geral de um indivíduo, (B) aspecto geral superficial de um ramo fértil, (C) vista frontal de célula apical evidenciada, (D) seção transversal do talo. 


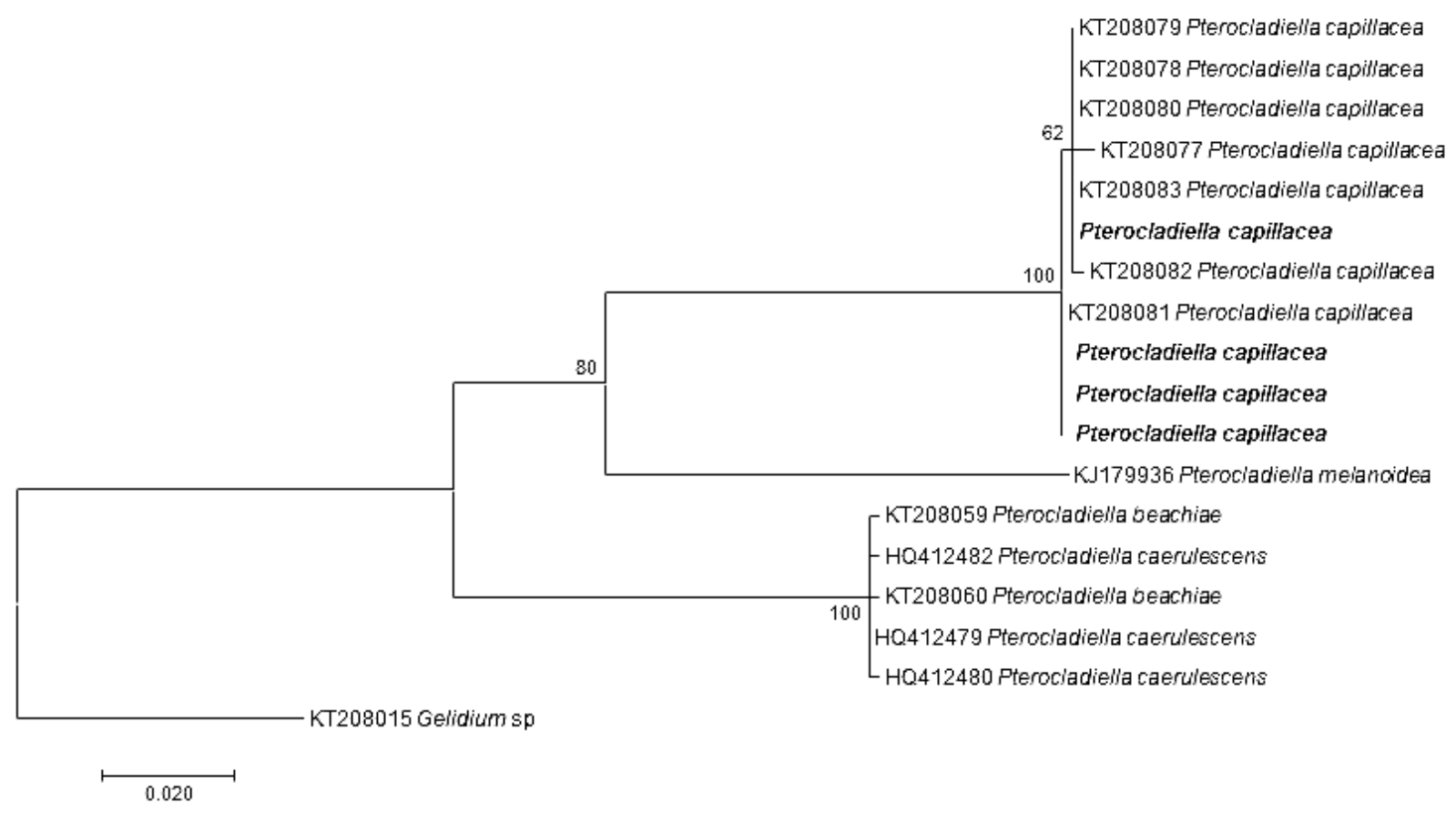

Figura 8. Árvore filogenética molecular construída pelo método da máxima verossimilhança.

A porcentagem da taxa de grupos associados é mostrada ao lado dos ramos da árvore. A árvore foi desenhada em escala, com comprimentos dos ramos medidos com base no número de substituições por sítio. Os dados em negrito representam às sequências obtidas pela espécie-alvo do presente estudo.

\subsection{Taxa de crescimento e fluorescência da clorofila $a$ em Pterocladiella capillacea}

A taxa de crescimento (TC) foi avaliada ao longo do tempo nas irradiâncias de 60 e $300 \mu \mathrm{mol}$ fótons.m $\mathrm{m}^{-2} \cdot \mathrm{s}^{-1}$ (Fig. 9). Após exposição às duas irradiâncias, P. capillacea apresentou aumento significativo da TC em $300 \mu \mathrm{mol}$ fótons. $\mathrm{m}^{-2} \cdot \mathrm{s}^{-1}$, com acréscimo de $199 \%$ em relação a $60 \mu \mathrm{mol}$ fótons. $\mathrm{m}^{-2} \cdot \mathrm{s}^{-1}$. 


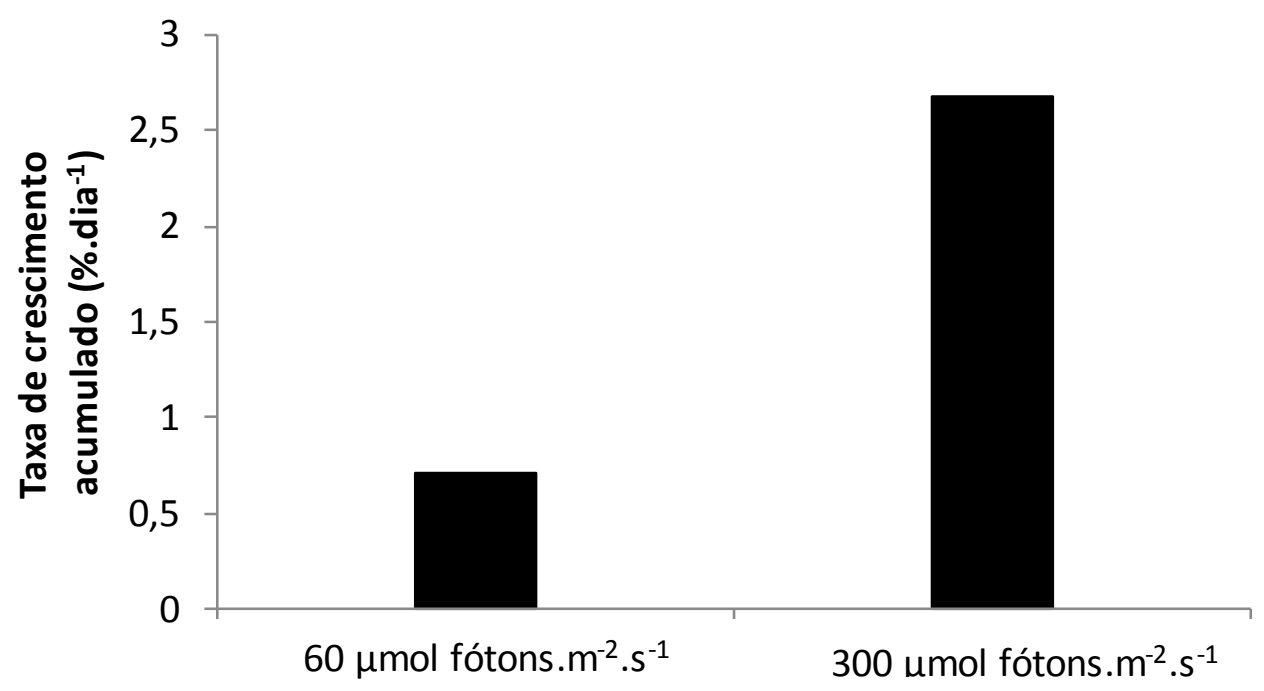

Figura 9. Taxa de crescimento acumulado de Pterocladiella capillacea ao longo do tempo de experimento nas irradiâncias de 60 e $300 \mu \mathrm{mol}$ fótons. $\mathrm{m}^{-2} \cdot \mathrm{s}^{-1}$.

Os rendimento quântico máximo (Fv/Fm; Fig. 10A), rendimento quântico efetivo (Y(II); Fig. 10B) e absorptância (Fig. 10C) foram medidos ao longo do tempo experimental para as duas irradiâncias. Os níveis de Fv/Fm, Y(II) e absorptância na irradiância de $60 \mu$ mol fótons. $\mathrm{m}^{-2} . \mathrm{s}^{-1}$ foram constantes ao longo do tempo, sem mostrar diferenças significativas. Em contrapartida, houve diminuição no $\mathrm{Fv} / \mathrm{Fm}$ sob $300 \mu \mathrm{mol}$ fótons. $\mathrm{m}^{-2} \cdot \mathrm{s}^{-1}$ em relação ao rendimento inicial (tempo 0) do mesmo tratamento. O Fv/Fm de P. capillacea sob $300 \mu \mathrm{mol}$ fótons. $\mathrm{m}^{-2} . \mathrm{s}^{-1}$ se mostrou menor quando comparada à irradiância controle $\left(60 \mu \mathrm{mol}\right.$ fótons. $\mathrm{m}^{-}$ ${ }^{2} \cdot \mathrm{s}^{-1}$ ), com exceção do tempo 3. O Y(II) apresentou respostas semelhantes que Fv/Fm, sendo seus níveis menores do que a irradiância controle, com exceção nos tempos 1 e 5. Quando comparados os rendimentos entre ambas irradiâncias, e considerando o mesmo período de tempo, é possível observar que $P$. capillacea sob $300 \mu \mathrm{mol}$ fótons. $\mathrm{m}^{-2} \cdot \mathrm{s}^{-1}$ foi sempre menor que o controle, salvo algumas exceções. A absorptância foi constante nas duas irradiâncias ao longo do tempo. Não foi possível detectar variação significativa do Fv/Fm, Y(II) e absorptância após a adição de meio de enriquecimento de VS $100 \%$ após o sétimo dia, exceto para o Y(II) no tempo 8. 

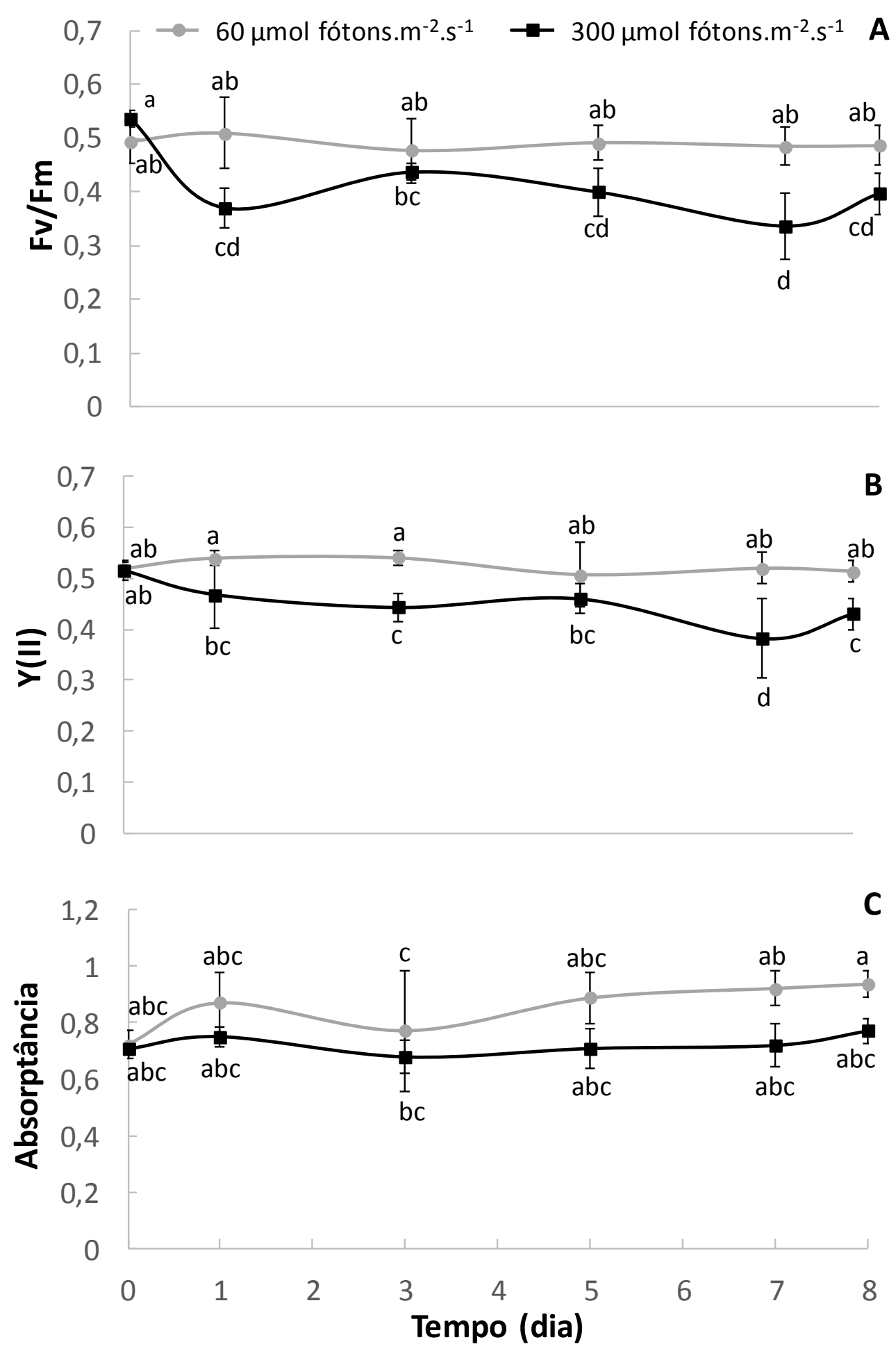

Figura 10. (A) Rendimento quântico ótimo (Fv/Fm), (B) rendimento quântico efetivo (Y(II)) e (C) absorptância de Pterocladiella capillacea ao longo de oito dias de experimento nas irradiâncias de 60 e $300 \mu \mathrm{mol}$ fótons. $\mathrm{m}^{-2} \cdot \mathrm{s}^{-1}$. Os valores representam a média \pm desvio padrão $(\mathrm{n}=5)$. Letras distintas indicam diferença significativa $(\mathrm{p}<0,05)$ após a ANOVA bifatorial e teste post-hoc de Newman-Keuls. 
As dissipações fotoquímica e não fotoquímicas de $P$. capillacea foram avaliadas para os dois tratamentos de irradiância ao longo do tempo (Fig. 11). Para $60 \mu \mathrm{mol}$ fótons. $\mathrm{m}^{-2} \cdot \mathrm{s}^{-1} \mathrm{a}$ dissipação fotoquímica (Y(PSII)) não apresentou variação ao longo dos dias, em contraposição, para $300 \mu \mathrm{mol}$ fótons. $\mathrm{m}^{-2} . \mathrm{s}^{-1} \mathrm{o}$ Y(PSII) foi diminuindo a partir de terceiro dia. Em relação à dissipação não fotoquímica não regulada (Y(NO)), a dissipação por calor sem gasto de energia, foi maior em $300 \mu \mathrm{mol}$ fótons. $\mathrm{m}^{-2} \cdot \mathrm{s}^{-1}$ do que $60 \mu \mathrm{mol}$ fótons. $\mathrm{m}^{-2} \cdot \mathrm{s}^{-1}$, exceto no tempo 5 em que ambas dissipações foram iguais (Fig. 11). Quanto à dissipação não fotoquímica regulada (Y(NPQ)), a dissipação energética com gasto de energia (ex. ciclo da xantofila), não registrou resultado para a irradiância de $60 \mu \mathrm{mol}$ fótons. $\mathrm{m}^{-2} \cdot \mathrm{s}^{-1}$ e nem para 300 $\mu \mathrm{mol}$ fótons. $\mathrm{m}^{-2} \cdot \mathrm{s}^{-1}$ (Fig 11).

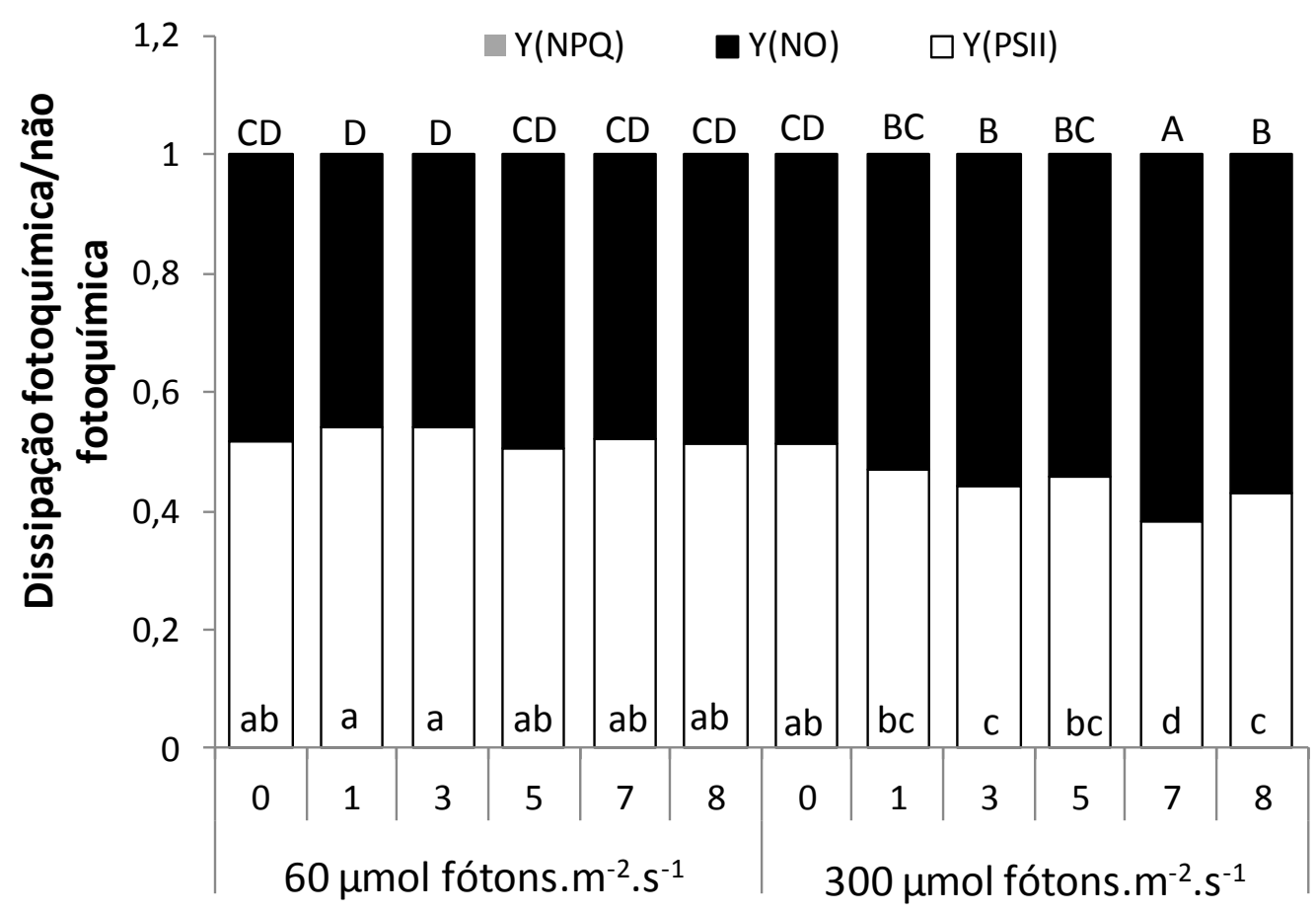

Figura 11. Dissipação fotoquímica (Y(PSII), dissipação não fotoquímica não regulada (Y(NO)) e dissipação não fotoquímica regulada (Y(NPQ)) de Pterocladiella capillacea ao longo de oito dias de experimento nas irradiâncias de 60 e $300 \mu \mathrm{mol}$ fótons. $\mathrm{m}^{-2} . \mathrm{s}^{-1}$. Os valores representam a média \pm desvio padrão $(n=5)$. Letras distintas indicam diferença significativa $(\mathrm{p}<0,05)$ após a ANOVA bifatorial e teste post-hoc de Newman-Keuls. 
A saturação luminosa (Ik) de $P$. capillacea sob $60 \mu \mathrm{mol}$ fótons. $\mathrm{m}^{-2} \cdot \mathrm{s}^{-1}$ mostrou diferença significativa apenas nos tempos 5 e 7 (Fig. 12A), que foram significativamente maiores que os valores alcançados em $300 \mu \mathrm{mol}$ fótons. $\mathrm{m}^{-2} . \mathrm{s}^{-1}$. Para algas crescidas em 300 $\mu$ mol fótons. $\mathrm{m}^{-2} \cdot \mathrm{s}^{-1}$, apenas o tempo 7 foi diferente dos demais tempos de cultivo dentre o mesmo tratamento, apresentando maior nível de saturação.

A taxa máxima de transporte de elétrons $\left(\mathrm{ETR}_{\text {máx }}\right)$ apresentou diferenças significativas nos tempos 1, 5, 7 e 8 para algas crescidas em $60 \mu$ mol fótons.m ${ }^{-2} \cdot \mathrm{s}^{-1}$ (Fig. 12B). Apesar de $\mathrm{ETR}_{\text {máx }}$ não ser significativo ao longo do período exprerimental em $300 \mu \mathrm{mol}$ fótons. $\mathrm{m}^{-2} \cdot \mathrm{s}^{-1}$, foi possível distinguir uma tendência de menores valores de $\mathrm{ETR}_{\operatorname{máx}}$ em $300 \mu$ mol fótons.m ${ }^{-}$ ${ }^{2} \cdot \mathrm{s}^{-1}$ quando comparados com as respostas em $60 \mu \mathrm{mol}$ fótons. $\mathrm{m}^{-2} \cdot \mathrm{s}^{-1}$.

A eficiência fotossintetizante $($ alfa; $\alpha$ ) não mostrou variação significativa para os tempos de cultivo dentro de $60 \mu \mathrm{mol}$ fótons. $\mathrm{m}^{-2} \cdot \mathrm{s}^{-1}$ ou $300 \mu \mathrm{mol}$ fótons. $\mathrm{m}^{-2} \cdot \mathrm{s}^{-1}$ (Fig. 12C) Comparando ambas irradiâncias, o tempo 5 foi o único tratamento diferente estatisticamente. Apesar desses resultados estatísticos, foi possível observar uma tendência de maiores valores para $300 \mu \mathrm{mol}$ fótons. $\mathrm{m}^{-2} . \mathrm{s}^{-1}$ nos tempos 3 e 5 , e menores valores nos tempos 7 e 8 .

Os resultados para as curvas de ETR x PAR estão apresentados na Figura 13. Houve variação entre os tratamentos ao longo dos dias, tendo obtido a maior curva de ETR x PAR no sétimo dia para $60 \mu \mathrm{mol}$ fótons. $\mathrm{m}^{-2} \cdot \mathrm{s}^{-1}$ (Fig. 13A) e no oitavo dia para $300 \mu \mathrm{mol}$ fótons. $\mathrm{m}^{-2} \cdot \mathrm{s}^{-1}$ (Fig. 13B). A magnitude da cinética das curvas em $300 \mu \mathrm{mol}$ fótons. $\mathrm{m}^{-2} \cdot \mathrm{s}^{-1}$ mostrou ser mais homogênea entre os dias, diferentes das curvas de $60 \mu \mathrm{mol}$ fótons. $\mathrm{m}^{-2} \cdot \mathrm{s}^{-1}$, onde observou-se grande variações ao longo do tempo. Ao comparar os dois tratamentos de luz, também há variações, no entanto não foi possível identificar um claro padrão. 

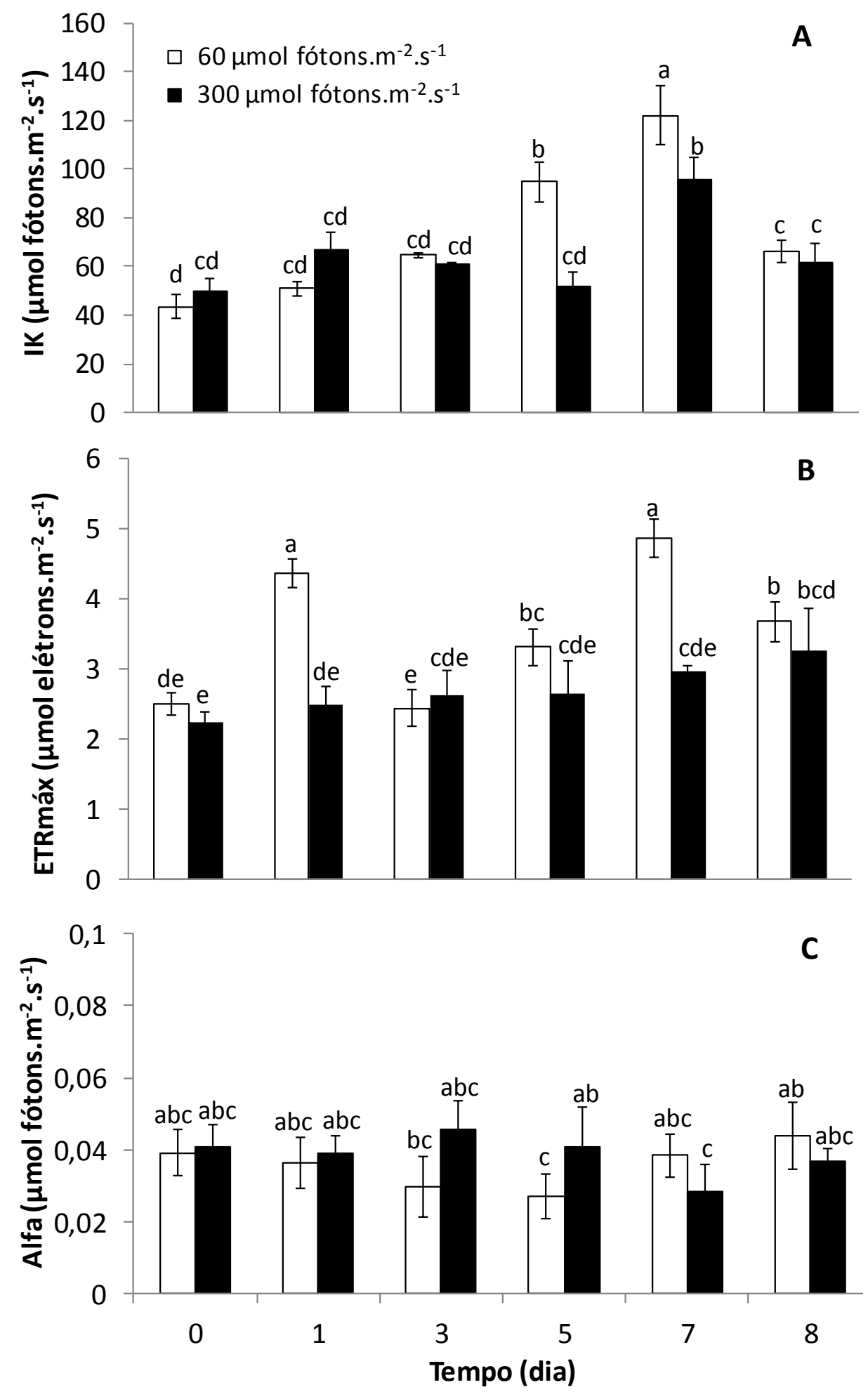

Figura 12. (A) Saturação luminosa, (B) taxa máxima de transporte de elétrons e (C) eficiência fotossintetizante de Pterocladiella capillacea ao longo de oito dias de experimento nas irradiâncias de 60 e $300 \mu \mathrm{mol}$ fótons. $\mathrm{m}^{-2} . \mathrm{s}^{-1}$. Os valores representam a média \pm desvio padrão $(n=5)$. Letras distintas indicam diferença significativa $(\mathrm{p}<0,05)$ após a ANOVA bifatorial e teste post-hoc de Newman-Keuls. 

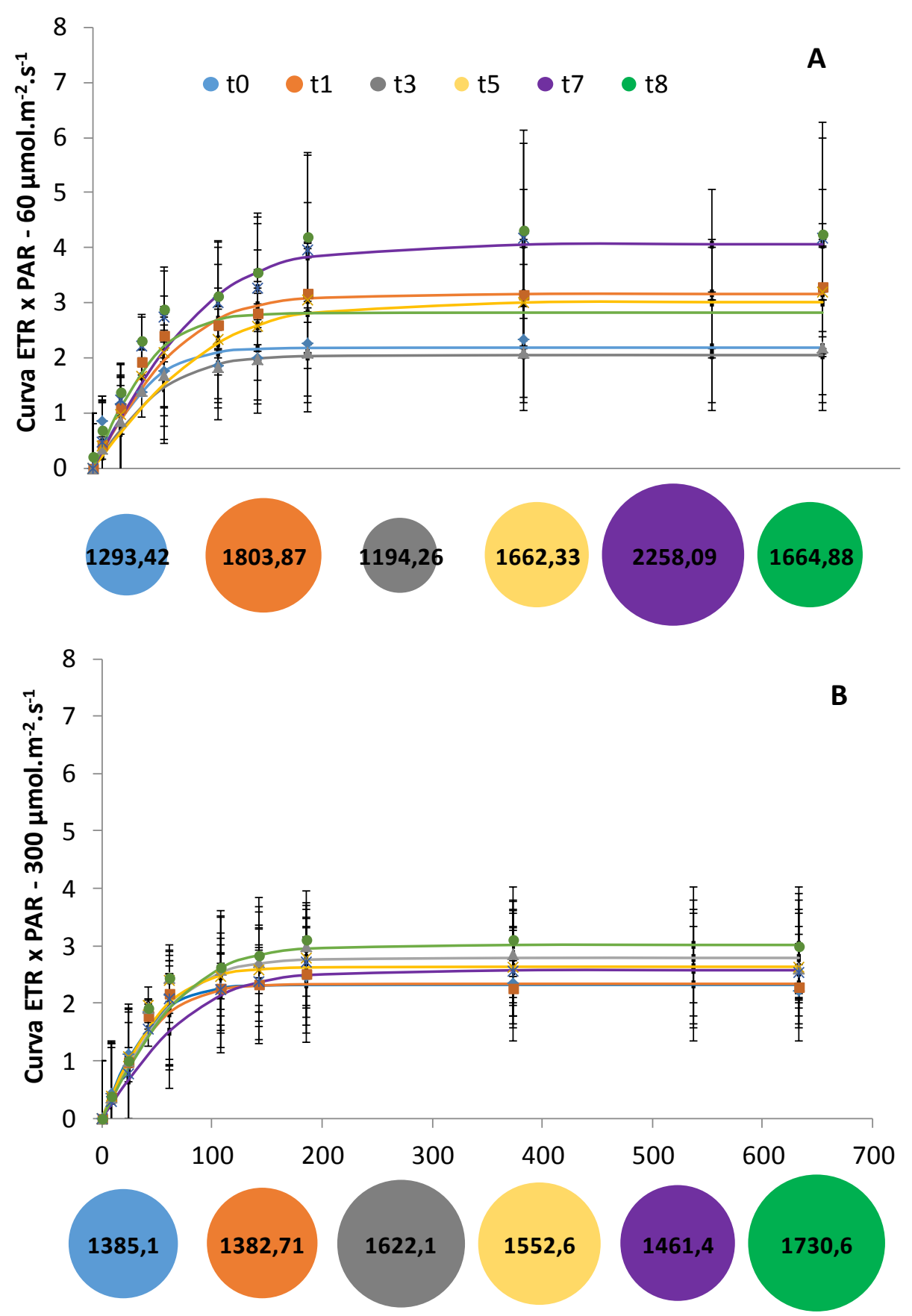

Figura 13. Curvas de ETR x PAR e a respectiva área sob a curva de Pterocladiella capillacea ao longo de oito dias de experimento (t0-t8) nas irradiâncias de (A) $60 \mu \mathrm{mol}$ fótons. $\mathrm{m}^{-2} . \mathrm{s}^{-1} \mathrm{e}$ (B) $300 \mu \mathrm{mol}$ fótons. $\mathrm{m}^{-2} \cdot \mathrm{s}^{-1}$. Os valores representam a média \pm desvio padrão $(\mathrm{n}=5)$.

\subsection{Pigmentos fotossintetizantes e proteínas solúveis totais}

A Figura 14 mostra os resultados do conteúdo pigmentar de P. capillacea ao longo do período experimental para 60 e $300 \mu \mathrm{mol}$ fótons. $\mathrm{m}^{-2} \cdot \mathrm{s}^{-1}$. 
De forma global, a concentração de pigmentos de $P$. capillacea sob 60 ou $300 \mu$ mol fótons. $\mathrm{m}^{-2} \cdot \mathrm{s}^{-1}$ mostrou variação significativa ao longo do período experimental, exceto para aloficacianina (Fig. 14C) e carotenoides (Fig. 14E), em que as variações foram menos expressivas entre os tratamentos. Para ficobilinas, foi possível distinguir aumento gradual ao longo do tempo nas amostras sob $60 \mu \mathrm{mol}$ fótons.m ${ }^{-2} \cdot \mathrm{s}^{-1}$, enquanto que para $300 \mu \mathrm{mol}$ fótons. $\mathrm{m}^{-2} \cdot \mathrm{s}^{-1}$ estes mesmos pigmentos tenderam a diminuir ao longo do tempo de crescimento (Fig. 14A-C). Respostas diferentes foram observadas para clorofila, na qual, em ambas irradiâncias, o teor desse pigmento diminuiu ao longo dos dias (Fig. 14D).
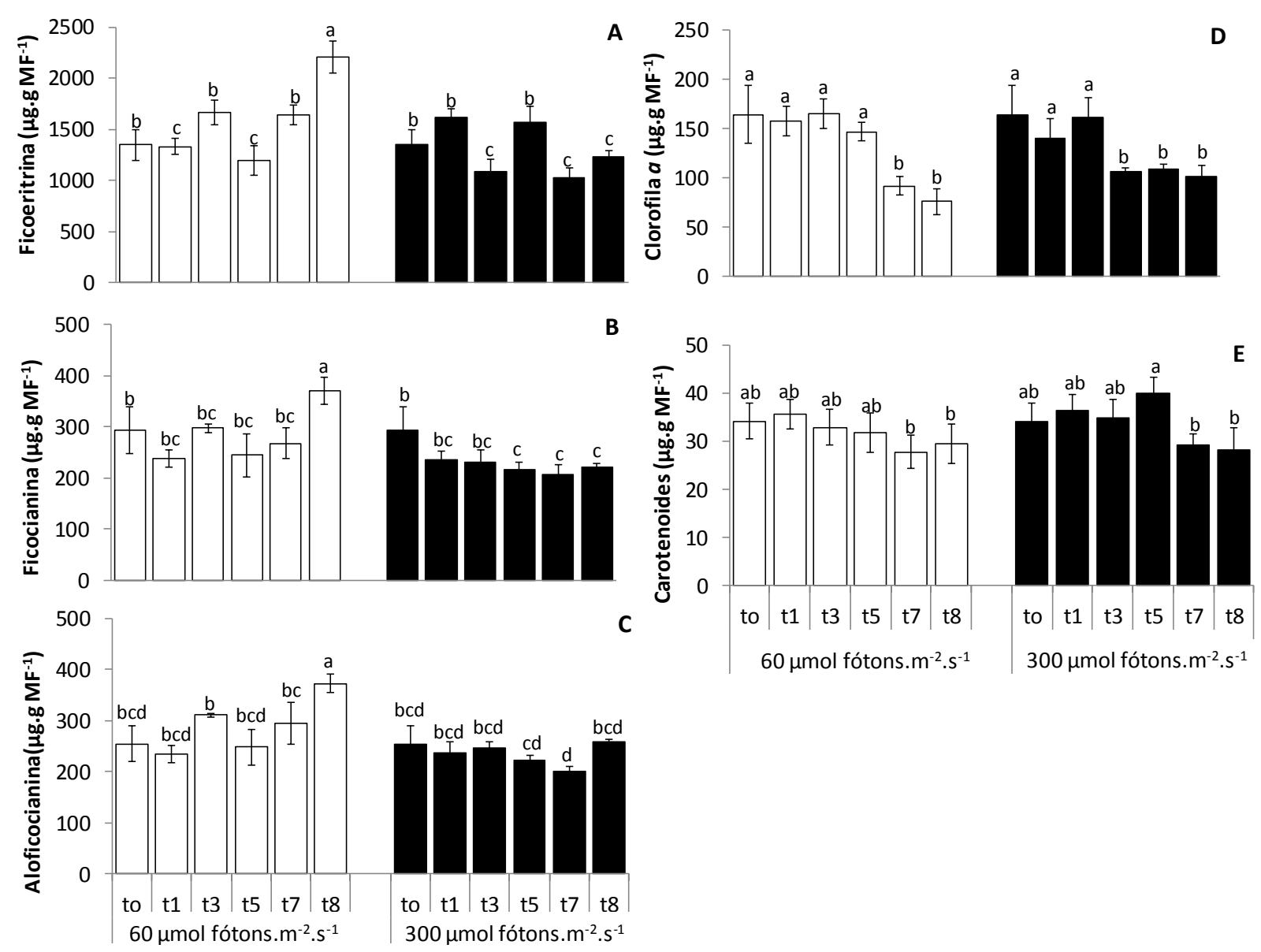

Figura 14. Conteúdo pigmentar de Pterocladiella capillacea ao longo de oito dias de experimento nas irradiâncias de 60 e $300 \mu \mathrm{mol}$ fótons. $\mathrm{m}^{-2} \cdot \mathrm{s}^{-1}$. (A) ficoeritrina, (B) ficocianina, (C) aloficocianina, (D) clorofila $a$ e (E) carotenoides totais. Os valores representam a média \pm desvio padrão $(\mathrm{n}=5)$. Letras distintas indicam diferença significativa $(\mathrm{p}<0,05)$ após a ANOVA bifatorial e teste post-hoc de Newman-Keuls. 
Os resultados de proteínas solúveis totais (Fig. 15) de $P$. capillacea mostraram que para ambas irradiâncias houve um aumento significativo a partir do terceiro dia de crescimento, quando comparados ao tempo inicial. Para os dois trataments de luz foram observados os mesmos níveis de proteínas, com aumento entre 22 a $63 \%$.

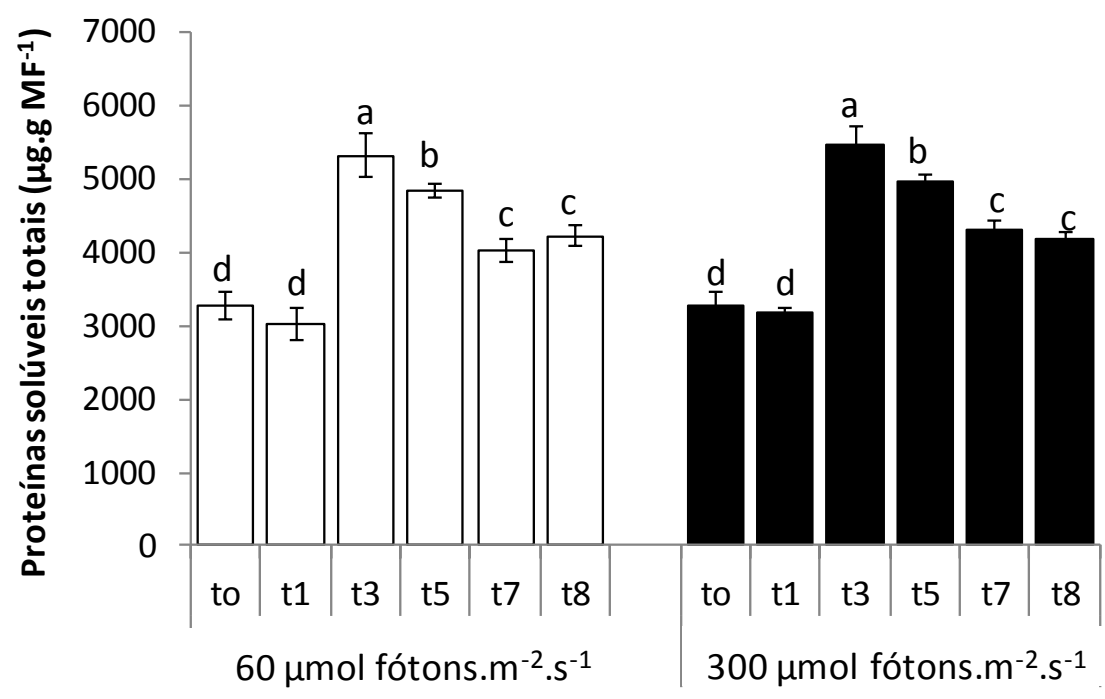

Figura 15. Conteúdo de proteínas solúveis totais ao longo do tempo de oito dias de experimento nas irradiâncias de 60 e $300 \mu \mathrm{mol}$ fótons. $\mathrm{m}^{-2} . \mathrm{s}^{-1}$. Os valores representam a média \pm desvio padrão $(\mathrm{n}=5)$. Letras distintas indicam diferença significativa $(\mathrm{p}<0,05)$ após a ANOVA bifatorial e teste post-hoc de Newman-Keuls.

O conteúdo de CHN de P. capillacea foi avaliado para os dois tratamentos de irradiância ao longo do tempo (Fig. 16). Não houve variação significativa no conteúdo de C (Fig. 16A), H (Fig. 16B) e N (Fig. 16C) ao longo do período de crescimento e nem entre as irradiâncias testadas.

A Figura 17 mostra os espectros de absorção dos extratos pigmentares tamponados de P.capillacea nos comprimentos de onda de 240 a $400 \mathrm{~nm}$. Os espectros mostraram distribuição semelhante para todos os tempos experimentais, foi possível vericar picos entre o intervalo de comprimento de onda de 300 e $360 \mathrm{~nm}$. Não foram obtidos resultados para o scan ultravioleta com os extratos metanólicos de pigmentos. 

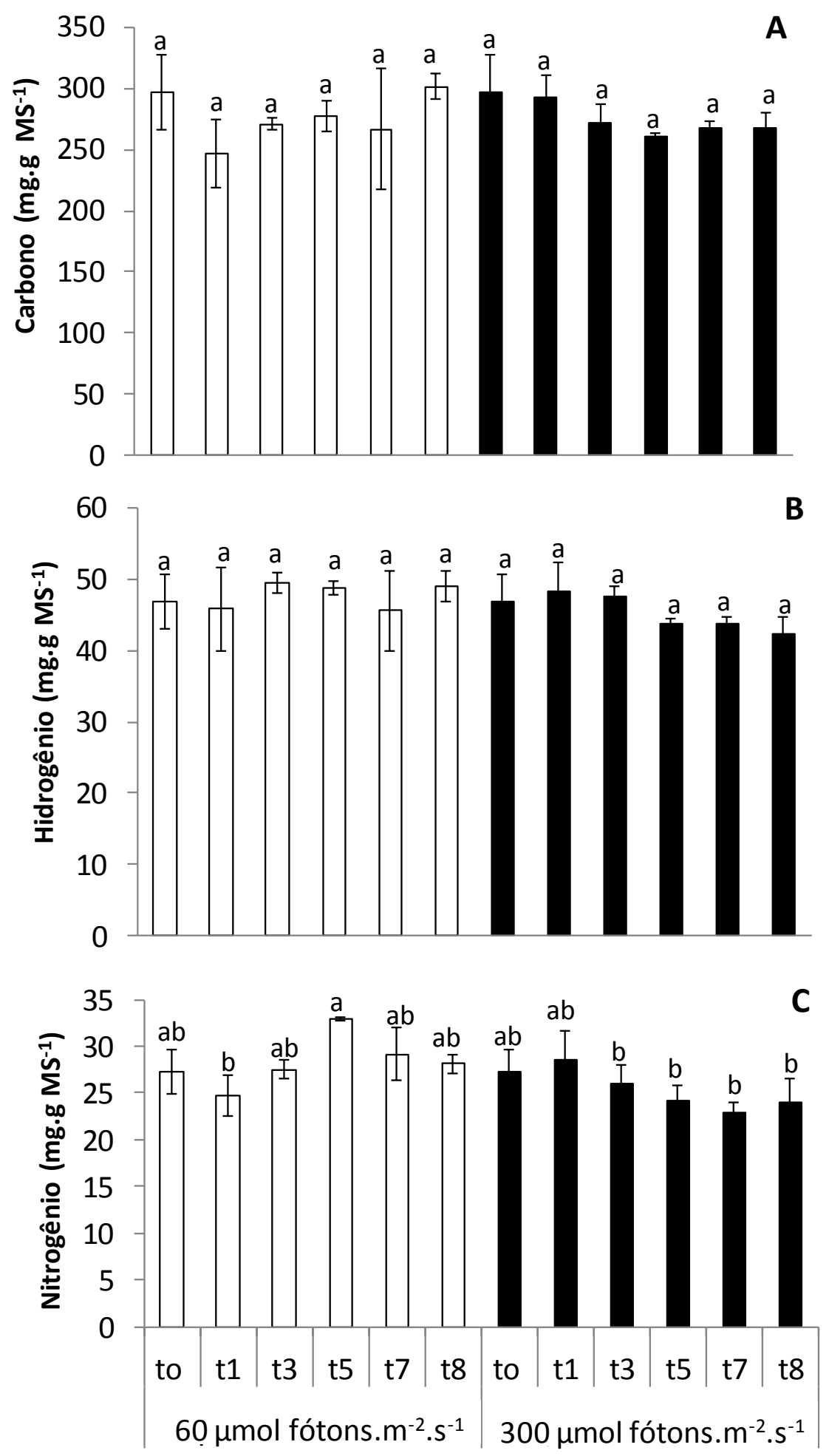

Figura 16. Conteúdo de (A) carbono, (B) hidrogênio e (C) nitrogênio de Pterocladiella capillacea ao longo de oito dias de experimento nas irradiâncias de 60 e $300 \mu$ mol fótons.m ${ }^{-}$ ${ }^{2} \cdot \mathrm{s}^{-1}$. Os valores representam a média \pm desvio padrão $(\mathrm{n}=5)$. Letras diferentes indicam diferença significativa $(\mathrm{p}<0,05)$ após a ANOVA bifatorial e teste post-hoc de NewmanKeuls. 

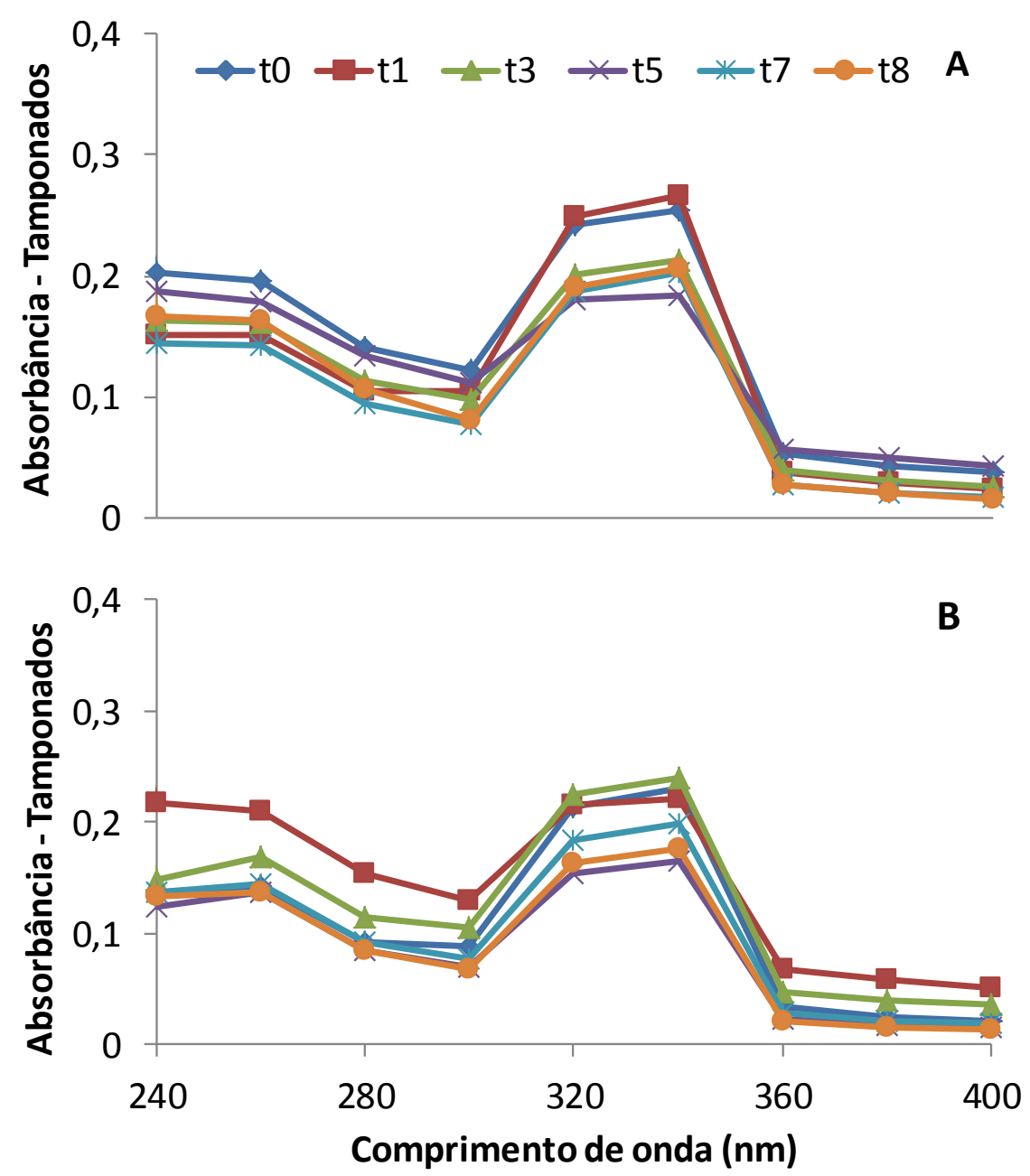

Figura 17. Espectro de absorção nos comprimentos de onda do UV dos extratos tamponados de pigmentos de P.capillacea ao longo de oito dias de experimento nas irradiâncias de (A) 60 $\mu \mathrm{mol}$ fótons. $\mathrm{m}^{-2} \cdot \mathrm{s}^{-1} \mathrm{e}$ (B) $300 \mu \mathrm{mol}$ fótons. $\mathrm{m}^{-2} \cdot \mathrm{s}^{-1}$.

As Tabelas 2 e 3 sintetizam alguns trabalhos que verificaram o efeito de PAR em algas vermelhas e analisaram parâmetros comuns ao presente estudo.

A Tabela 2 reúne trabalhos que verificaram alguns parâmetros fotossintetizantes. Nesta compilação de dados vale destacar os resultados de dissipação não fotoquímica regulada Y(NPQ). No presente estudo, nenhuma das irradiâncias testadas ativou esse mecanismo, ou seja, $P$. capillacea não dissipou calor com gasto de energia, em contrapartida algas do gênero Porphyra C. Agardh tiveram esses mecanismos ativados sob influência de irradiâncias menores do que as testadas em P.capillacea. 
Tabela 2. Sumário de alguns estudos mostrando parâmetros fotossintetizantes como eficiência quântica ( $\alpha$ ), dissipação não fotoquímica não fotoquímica regulada $\mathrm{Y}(\mathrm{NPQ})$, taxa máxima de transporte de elétrons $\left(\mathrm{ETR}_{\text {máx }}\right)\left(\mu \mathrm{mol}\right.$ elétrons.m $\left.{ }^{-2} \cdot \mathrm{s}^{-1}\right)$, saturação luminosa (Ik) ( $\mu$ mol fótons.m ${ }^{-}$ $\left.{ }^{2} \cdot \mathrm{s}^{-1}\right)$ em macroalgas vermelhas.

\begin{tabular}{|c|c|c|c|c|c|c|}
\hline Alga & PAR & $\alpha$ & $\mathrm{Y}(\mathrm{NPQ})$ & $\mathrm{ETR}_{\text {máx }}$ & IK & Referência \\
\hline \multirow[t]{5}{*}{ Porphyra leucostica } & 50 & - & $0,06 \pm 0,00$ & $2,30 \pm 0,15$ & - & Figueroa et al. (2003a) \\
\hline & 100 & - & $0,11 \pm 0,01$ & $4,10 \pm 0,21$ & - & \\
\hline & 500 & - & $0,22 \pm 0,01$ & $13,20 \pm 1,10$ & - & \\
\hline & 1000 & - & $0,36 \pm 0,03$ & $13,90 \pm 1,30$ & - & \\
\hline & 2000 & - & $0,58 \pm 0,04$ & $20,70 \pm 2,10$ & - & \\
\hline Ahnfeltiopsis durvillaei & 2000 & $0,22 \pm 0,02$ & - & $31,30 \pm 3,70$ & $138,60 \pm 8,70$ & Gomez et al. (2004) \\
\hline Callophyllis variegata & 2000 & $0,14 \pm 0,02$ & - & $11,20 \pm 2,30$ & $81,90 \pm 20,10$ & \\
\hline Gelidium lingulatum & 2000 & $0,34 \pm 0,03$ & - & $80,90 \pm 10,40$ & $335,60 \pm 21,20$ & \\
\hline Gracilaria chilensis & 2000 & $0,15 \pm 0,00$ & - & $28,20 \pm 4,60$ & $182,80 \pm 34,10$ & \\
\hline Grateloupia doryphora & 2000 & $0,21 \pm 0,04$ & - & $21,20 \pm 2,70$ & $104,00 \pm 35,50$ & \\
\hline Gymnogongrus furcellatus & 2000 & $0,16 \pm 0,04$ & - & $20,70 \pm 11,30$ & $117,70 \pm 47,10$ & \\
\hline Laingia hookerii & 2000 & $0,13 \pm 0,03$ & - & $33,80 \pm 5,60$ & $256,10 \pm 25,60$ & \\
\hline Mazzaella laminarioides & 2000 & $0,06 \pm 0,01$ & - & $14,10 \pm 2,30$ & $237,20 \pm 73,80$ & \\
\hline Polysiphonia sp. & 2000 & $0,14 \pm 0,01$ & - & $33,80 \pm 8,70$ & $237,40 \pm 69,60$ & \\
\hline Porphyra columbina (sol) & 2000 & $0,20 \pm 0,09$ & - & $20,50 \pm 7,60$ & $136,50 \pm 116,10$ & \\
\hline Porphyra columbina (sombra) & 2000 & $0,14 \pm 0,01$ & - & $25,60 \pm 2,60$ & $179,90 \pm 25,10$ & \\
\hline Sarcothalia crispata & 2000 & $0,13 \pm 0,00$ & - & $24,80 \pm 5,60$ & $181,70 \pm 40,20$ & \\
\hline \multirow[t]{2}{*}{ Gracilaria domingensis } & 80 & $0,07 \pm 0,01$ & - & $29,00 \pm 0.70$ & - & Schmidt et al. (2010) \\
\hline & $80+$ UVBR (1.6) & $0,04 \pm 0,01$ & - & $17,00 \pm 0,40$ & - & \\
\hline \multirow[t]{2}{*}{ Gelidium floridanum } & 80 & $0,11 \pm 0,01$ & - & $11,75 \pm 0,35$ & $452,00 \pm 23,80$ & Schmidt et al. (2012b) \\
\hline & $80+$ UVBR (1.6) & $0,03 \pm 0,00$ & - & $5,22 \pm 0.76$ & $576,00 \pm 24,20$ & \\
\hline \multirow[t]{3}{*}{ Porphyra sp. } & Primavera (norte Chile) & $0,03 \pm 0,01$ & $0,60 \pm 0,13$ & $1,70 \pm 0,40$ & $54,20 \pm 18,10$ & Tala \& Chow (2014) \\
\hline & Primavera (centro Chile) & $0,04 \pm 0,01$ & $0,58 \pm 0,21$ & $5,60 \pm 1,70$ & $151,90 \pm 54,50$ & \\
\hline & Primavera (sul Chile) & $0,04 \pm 0,00$ & $0,66 \pm 0,22$ & $5,30 \pm 0,80$ & $151,00 \pm 22,00$ & \\
\hline Gracilariopsis lemaneiformis & 200 & $0,29 \pm 0,02$ & - & $70,70 \pm 7,97$ & $271,90 \pm 44,70$ & Zou \& Gao (2014) \\
\hline \multirow[t]{2}{*}{ Gracilaria lemaneiformis } & 40 & $0,14 \pm 0,01$ & - & $24,46 \pm 1,80$ & $134,68 \pm 5,60$ & Zhu et al. (2015) \\
\hline & $40+$ UVBR (1.8) & $0,07 \pm 0,01$ & - & $10,57 \pm 0,41$ & $58,82 \pm 1,29$ & \\
\hline \multirow[t]{2}{*}{ Pterocladiella capillacea } & 60 & $0,04 \pm 0,01$ & 0 & $4,86 \pm 0,28$ & $122,17 \pm 11,92$ & Presente estudo \\
\hline & 300 & $0,03 \pm 0,00$ & 0 & $2,96 \pm 0,07$ & $95,90 \pm 8,78$ & \\
\hline
\end{tabular}


A Tabela 3 mostra estudos que avaliaram taxa de crescimento (TC), conteúdo de CHN, pigmentos e proteínas solúveis totais. Observa-se que as respostas de algas vermelhas podem variar em razão da intensidade luz ou da espécie. Por exemplo, a taxa de crescimento em $P$. capillacea sob irradiância de $60 \mu \mathrm{mol}$ fótons. $\mathrm{m}^{-2} \cdot \mathrm{s}^{-1}$ foi constante, no entanto sob a mesma irradiância, as algas vermelhas Gracilariopsis tenuifrons (C.J.Bird \& E.C.Oliveira) Fredericq \& Hommersand e Iridea cordata (Turner) Bory de Saint-Vincent tiveram suas taxas de crescimento aumentadas. Gelidium floridanum W.R.Taylor e Gracilaria domingensis (Kützing) Sonder ex Dickie tiveram suas TC aumentadas e conteúdo pigmentar constante sob irradiância de $80 \mu \mathrm{mol}$ fótons. $\mathrm{m}^{-2} \cdot \mathrm{s}^{-1}$. No presente estudo, o único pigmento constante sob intensidade de luz foi carotenoides. 
Tabela 3. Influência da irradiância PAR em algas vermelhas quanto à: taxa de crescimento, conteúdo pigmentar (Chl $a-$ clorofila, FE ficoeritrina, FC - ficocianina, ALC - aloficocianina e Car - carotenoides, expressos em $\left.\mu \mathrm{g} \cdot \mathrm{g}^{-1}\right)$, PST - proteínas solúveis totais ( $\mu$ g.g $\mathrm{g}^{-1}$ ).

\begin{tabular}{|c|c|c|c|c|c|c|c|c|c|}
\hline Alga & PAR & TC & $\mathrm{Clh} a$ & FE & FC & ALC & Car & PST & Referência \\
\hline Chondrus crispus & $\begin{array}{l}900 p / 1800 \\
900 p / 3600\end{array}$ & - & $\begin{array}{l}\text { Aumentou } \\
\text { Reduziu }\end{array}$ & - & - & - & $\begin{array}{l}\text { Aumentou } \\
\text { Aumentou }\end{array}$ & - & Yakovleva \& Titlyanov (2001) \\
\hline Gracilaria domingensis & 80 p/ UVBR (1.6) & Aumentou & Constante & Constante & Constante & Constante & - & - & Schmidt et al. (2010) \\
\hline Gelidium floridanum & 80 p/ UVBR (1.6) & Aumentou & Constante & Constante & Constante & Constante & Constante & - & Schmidt et al. (2012) \\
\hline Gracilariopsis tenuifrons & $\begin{array}{l}60 p / 600 \\
60 p / 1000\end{array}$ & $\begin{array}{l}\text { Aumentou } \\
\text { Aumentou }\end{array}$ & $\begin{array}{l}\text { Reduziu } \\
\text { Reduziu }\end{array}$ & - & - & - & $\begin{array}{l}\text { Reduziu } \\
\text { Reduziu }\end{array}$ & - & Torres et al. (2015) \\
\hline Gracilariopsis tenuifrons & $60 \mathrm{p} / 600$ & Aumentou & Reduziu & Reduziu & Reduziu & Reduziu & Reduziu & Reduziu & Serra (2013) \\
\hline Gracilariopsis tenuifrons & $100 p / 1000$ & - & Constante & Constante & Constante & - & Aumentou & - & Zubia et al. (2014) \\
\hline Gracilaria tenuistipitata & $\begin{array}{l}40 p / 500 \\
500 p / 40\end{array}$ & - & $\begin{array}{l}\text { Reduziu } \\
\text { Aumentou }\end{array}$ & $\begin{array}{l}\text { Reduziu } \\
\text { Aumentou }\end{array}$ & $\begin{array}{l}\text { Reduziu } \\
\text { Aumentou }\end{array}$ & $\begin{array}{l}\text { Reduziu } \\
\text { Aumentou }\end{array}$ & $\begin{array}{l}\text { Reduziu } \\
\text { Aumentou }\end{array}$ & - & Carnicas et al. (1999) \\
\hline Iridaea cordata & $\begin{array}{c}55 \text { p/UVB }(0,5) \\
55 \text { p/UVB }(0,83)\end{array}$ & $\begin{array}{l}\text { Constante } \\
\text { Constante }\end{array}$ & $\begin{array}{l}\text { Constante } \\
\text { Constante }\end{array}$ & $\begin{array}{l}\text { Constante } \\
\text { Diminuiu }\end{array}$ & $\begin{array}{l}\text { Constante } \\
\text { Diminuiu }\end{array}$ & $\begin{array}{l}\text { Constante } \\
\text { Constante }\end{array}$ & - & - & Navarro et al. (2010) \\
\hline Porphyra leucostica & $\begin{array}{c}50 p / 100 \\
50 p / 500 \\
50 p / 1000 \\
50 p / 2000\end{array}$ & $\begin{array}{l}\text { Aumentou } \\
\text { Aumentou } \\
\text { Aumentou } \\
\text { Aumentou }\end{array}$ & $\begin{array}{l}\text { Aumentou } \\
\text { Reduziu } \\
\text { Reduziu } \\
\text { Reduziu }\end{array}$ & $\begin{array}{l}- \\
- \\
-\end{array}$ & $\begin{array}{l}- \\
- \\
-\end{array}$ & $\begin{array}{l}- \\
- \\
-\end{array}$ & $\begin{array}{l}- \\
- \\
-\end{array}$ & $\begin{array}{l}- \\
- \\
-\end{array}$ & Figueroa et al. (2003a) \\
\hline Porphyra acanthophora & $60 \mathrm{p} /$ UVB $(0,35)$ & Aumentou & Aumentou & Aumentou & Aumentou & Aumentou & Aumentou & Reduziu & Bouzon et al. (2012) \\
\hline Pterocladiella capillacea & $60 p / 300$ & Aumentou & Reduziu & Reduziu & Reduziu & Constante & Constante & Aumentou & Presente estudo \\
\hline
\end{tabular}


A PCA formada pelos componentes 1 e 2 é a significância estatística de valores que estão de acordo com as correlações de Pearson (ver Anexo V, Fig. AV 1 e Tabela AV 1). Os resultados da análise de componentes principais (PCA) permitem explicar 69,52\% das tendências dos resultados aqui expostos (Fig. 18).

As variações dos dados são diretamente proporcionais aos tratamentos para os quais seus dos vetores estão apontados. Taxa de crescimento, proteínas solúveis totais, dissipação não fotoquímica não regulada e saturação luminosa (t0 inicial, t1, t3 e t5 de $60 \mu$ mol fótons.m ${ }^{-}$ $\left.{ }^{2} \cdot \mathrm{s}^{-1}\right)$. Área de ETR x PAR, ETR ${ }_{\text {máx }}$ ficocianina, ficoeritrina, aloficocianina, rendimento quântico efetivo, dissipação fotoquímica e clorofila $a$ (t1, t3, t5, t7 e t8 de $300 \mu$ mol fótons.m ${ }^{-}$ ${ }^{2} \cdot \mathrm{s}^{-1}$. Esses ensaios foram responsáveis pela maior variação entre todo o conjunto de dados para os respectivos tratamentos. Nenhuma variável foi correlacionada para os tempos 7 e 8 de $60 \mu \mathrm{mol}$ fótons. $\mathrm{m}^{-2} \cdot \mathrm{s}^{-1}$ (Fig. 18).

Em $60 \mu \mathrm{mol}$ fótons. $\mathrm{m}^{-2} \cdot \mathrm{s}^{-1}$, os tempos iniciais se agrupam (t0-t3), a medida que aumenta o tempo ele vai se distanciando dos menores. Em geral três grupos foram identificados na PCA: (a) um grupo formado por todos os tratamentos sob $60 \mu$ mol fótons.m ${ }^{-}$ ${ }^{2} \cdot \mathrm{s}^{-1}$, exceto os tempos 7 e 8 , mais o t0 sob $300 \mu \mathrm{mol}$ fótons. $\mathrm{m}^{-2} \cdot \mathrm{s}^{-1}$, (b) um segundo grupo incluindo os tempos finais 7 e 8 de $60 \mu \mathrm{mol}$ fótons. $\mathrm{m}^{-2} . \mathrm{s}^{-1} \mathrm{e}$ (c) um outro grupo juntando todos os tratamentos sob $300 \mu \mathrm{mol}$ fótons. $\mathrm{m}^{-2} . \mathrm{s}^{-1}$, exceto o tempo $0 . \mathrm{O}$ dendrograma de cluster (Fig.19) corrobora com estes dados evidenciados na PCA. Dessa forma, foi possível verificar que existiu uma relação mais próxima e homogênea entre os tempos de $300 \mu \mathrm{mol}$ fótons. $\mathrm{m}^{-2} . \mathrm{s}^{-}$ ${ }^{1}$ e duas relações puderam ser distinguidas entre os tempos de $60 \mu \mathrm{mol}$ fótons. $\mathrm{m}^{-2} \cdot \mathrm{s}^{-1}$.

O gráfico biplot da PCA (Fig. 18) mostra que a variação nos tratamentos de $300 \mu \mathrm{mol}$ fótons. $\mathrm{m}^{-2} \cdot \mathrm{s}^{-1}$ é melhor explicada, principalmente, por nove parâmetros: Área ETR, ETR máx, FE, ALC, FC, Fv/Fm, Y(II), Y(PSII), Chl. Para os tratamentos de $60 \mu$ mol fótons.m ${ }^{-2} \cdot \mathrm{s}^{-1}$, exceto para os tempos 7 e 8, quatro métricas explicam a maior variação desse conjunto: Ik, PST, Y(NO) e TC. Os vetores mostram que a maior variação positiva dentre os dados foram para os tratamentos com maior irradiância (Fig. 18). 


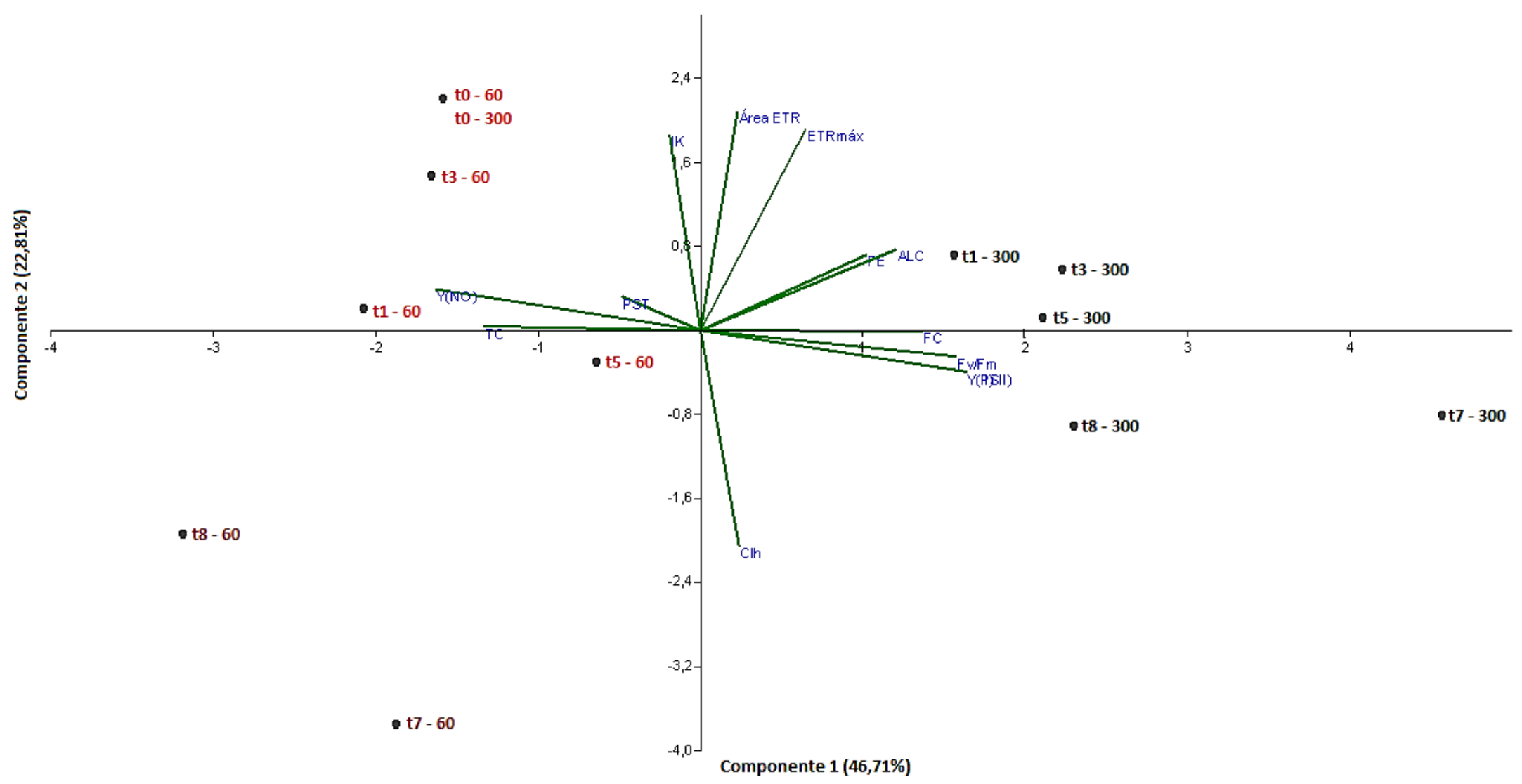

Figura 18. Ordenação biplot dos componentes 1 e 2 de $P$. capillacea durante o periodo experimental (t0, t1, t3, t5, t7 e t8) em função das variáveis métricas de ALC (aloficocianina), Área ETR (área de ETR x PAR), ETR máx (taxa máxima de transporte de elétrons), Clh (clorofila), FC (ficocianina), FE (ficoeritrina), Fv/Fm (rendimento quântico máximo), Ik (saturação luminosa), PST (proteínas solúveis totais), TC (taxa de crescimento), Y(II) (rendimento quântico efetivo), Y(NO) (dissipação não fotoquímica não regulada) e Y(PSII) (dissipação fotoquímica) para irradiâncias de 60 e $300 \mu \mathrm{mol}$ fótons. $\mathrm{m}^{-2} \cdot \mathrm{s}^{-1}$. As cores vermelha, marrom e preta indicadas em cada tratamento representam os três agrupamentos. 


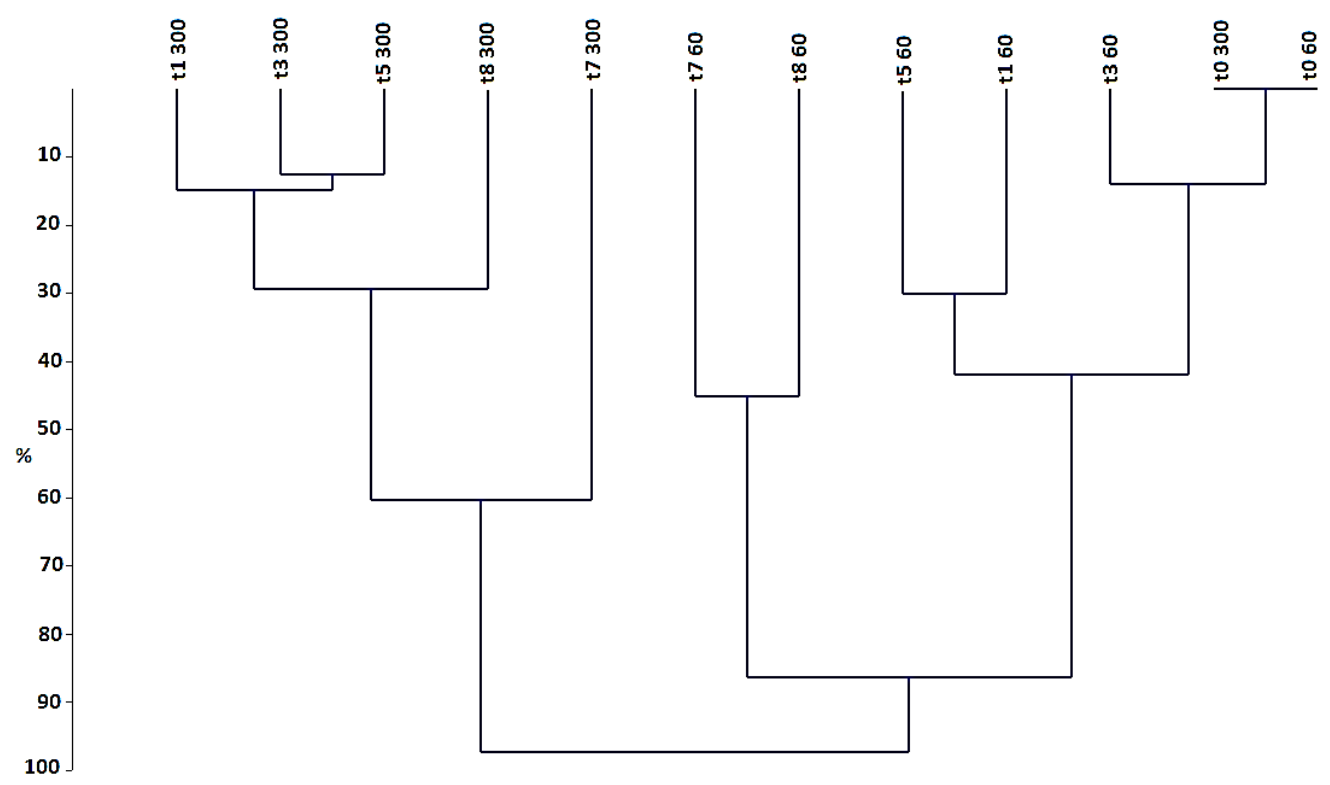

Figura 19. Dendrograma obtido da análise de agrupamento hierárquico utilizando os tratamentos de Pterocladiella capillacea ao longo do tempo (t0, t1, t3, t5, t7 e t8) para irradiâncias de 60 e $300 \mu \mathrm{mol}$ fótons. $\mathrm{m}^{-2} \cdot \mathrm{s}^{-1}$.

O cluster de agrupamento considerando as métricas obtidas no experimento com P.capillacea é mostrado na Figura 20. Dentre os parâmetros testados, Clorofila $a$ (Clh) foi a variável mais divergente no dendograma, observando-se diversos agrupamentos entre as variáveis.

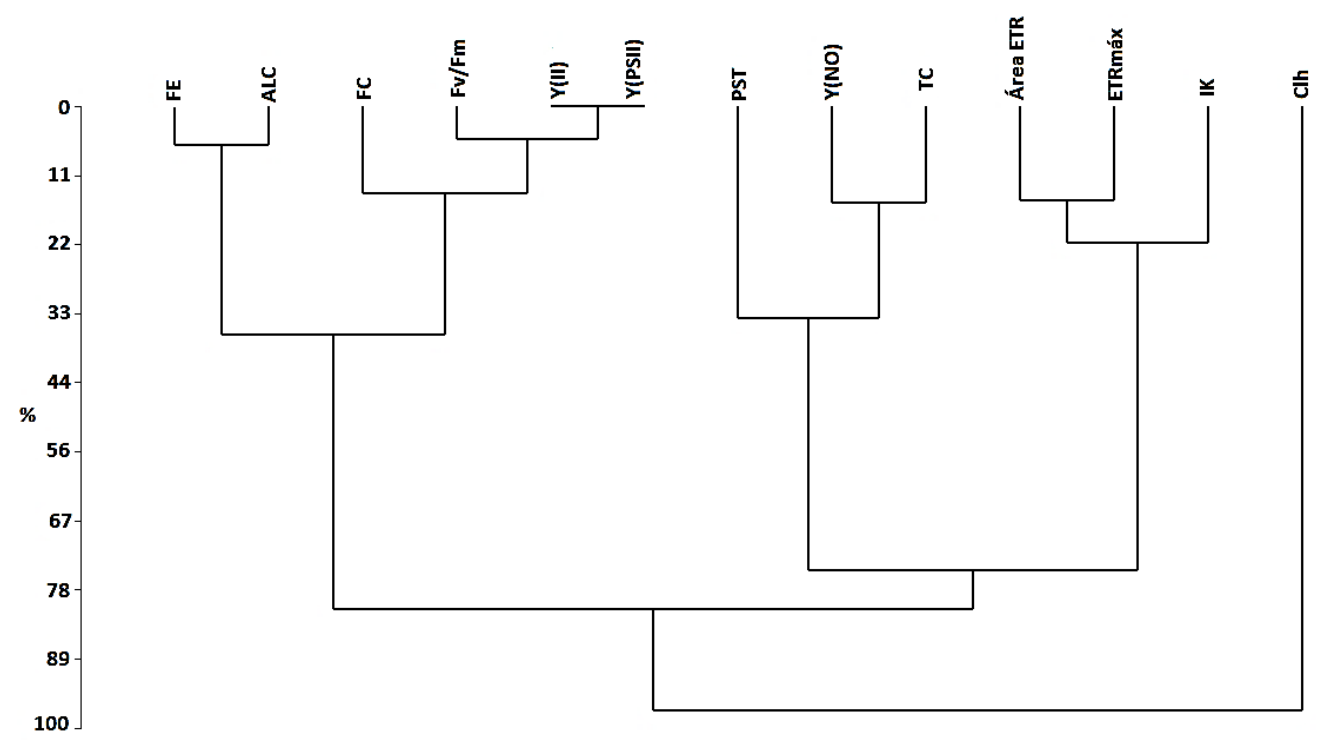

Figura 20. Dendrograma obtido da análise de agrupamento hierárquico utilizando as métricas resultantes de Pterocladiella capillacea avaliadas nos diferentes tempos e irradiâncias. 


\section{Discussão}

A compreensão do conjunto de parâmetros químicos $(\mathrm{CHN}$; conteúdo pigmentar; proteínas solúveis totais) e fisiológicos (taxa de crescimento; desempenho fotossintetizante) aqui expostos fornecem importantes subsídios para o entendimento da fotossensibilidade em P.capillacea.

Nesse contexto, a taxa de crescimento de P. capillacea foi estimulada pelo aumento da irradiância. No entanto, estes resultados não foram acompanhados por aumento na fotossíntese, o qual mostrou leve redução de 60 para $300 \mu \mathrm{mol}$ fótons. $\mathrm{m}^{-2}$.s 1 . Esses resultados indicam que $300 \mu \mathrm{mol}$ fótons. $\mathrm{m}^{-2} \cdot \mathrm{s}^{-1}$, sob as condições experimentais estudadas, não consituiu uma condição de fotoestresse que levasse a situações de fotodano do aparelho fotossintetizante e que provavelmente os mecanismos de defesa, como a dissipação não fotoquímica não regulada, foram eficientes para a proteção do aparato fotossintetizantes em P.capillacea.

Resultados semelhantes foram observados por Torres et al. (2014) e Serra (2013) para G. tenuifrons, em que também registraram incremento no crescimento quando cultivada em laboratório sob 600 e $1000 \mu \mathrm{mol}$ fótons.m ${ }^{-2} \cdot \mathrm{s}^{-1}$. Porém, os autores observaram fotoinibição da fotossíntese e fotodano no aparelho fotossintetizante.

Em Laurencia dendroidea J. Agardh, Sudatti et al. (2011) também verificaram que o aumento da irradiância $\left(15,30,60,120\right.$ e $190 \mu \mathrm{mol}$ fótons.m $\left.{ }^{-2} \cdot \mathrm{s}^{-1}\right)$ foi acompanhado pelo crescimento da espécie. Embora os autores não tenham realizado medidas de taxa fotossintetizante, foi concluído que os níveis testados não caracterizavam condições de fotoinibição.

Trabalhando com P. capillacea, Gal-Or \& Israel (2004) mostraram que a irradiância teve efeitos significativos sobre as taxas de crescimento da espécie, observando que as baixas irradiâncias durante o inverno (100 - $500 \mu \mathrm{mol}$ fótons. $\left.\mathrm{m}^{-2} \cdot \mathrm{s}^{-1}\right)$ estimularam as taxas de crescimento, por outro lado, irradiâncias maiores no verão (400 - $800 \mu \mathrm{mol}$ fótons. $\mathrm{m}^{-2} \cdot \mathrm{s}^{-1}$ ) inibiram as taxas de crescimento de $P$. capillacea. Nossos resultados de taxa de crescimento em $300 \mu \mathrm{mol}$ fótons. $\mathrm{m}^{-2} \cdot \mathrm{s}^{-1}$ seguem a mesma tendência de respostas de inverno do estudo de Gal-Or \& Israel (2004). Pterocladiella capillacea é caracterizada por ser uma alga de sombra pelo qual seria esperado que irradiâncias elevadas afetassem negativamente tanto o crescimento como a fotossíntese.

No Espírito Santo, a média mensal de irradiância durante o verão de Janeiro de 2016 ficaram em torno $1.012 \mu \mathrm{mol}$ fótons. $\mathrm{m}^{-2} . \mathrm{s}^{-1}$ e a média mensal para o inverno de 
Julho de 2015 registraram $512 \mu \mathrm{mol}$ fótons. $\mathrm{m}^{-2} . \mathrm{s}^{-1}$ (CPTEC, 2016). Esses valores médios de irradiância se assemelham aos reportados por Gal-Or \& Israel (2004), o qual pode se assumir que níveis acima de 500 a $600 \mu \mathrm{mol}$ fótons. $\mathrm{m}^{-2} \cdot \mathrm{s}^{-1}$ sejam prejudiciais para o metabolismo de $P$. capillacea.

Baixos valores de Fv/Fm, indicam que a alga é menos receptiva a níveis elevados de radiação. Algas vermelhas costumam apresentar baixos valores de rendimento quântico, seja ele ótimo ou efetivo. A diminuição no $\mathrm{Fv} / \mathrm{Fm}$ em $P$. capillacea sob $300 \mu \mathrm{mol}$ fótons. $\mathrm{m}^{-2} \cdot \mathrm{s}^{-1}$ demonstra um processo de fotoaclimatação, na qual parte da energia incidente foi dissipada como calor por processos não fotoquímicos e não regulados, ou seja, mecanismos de extinção energética por produção de calor na forma de radiação infravermelha de passiva, sem gasto energético pela célula. Esse mecanismo foi eficiente na espécie, pois a redução no Fv/Fm não levou a diminuição da taxa de crescimento, corroborando a presença de fotoaclimatação sem comprometimento do metabolismo geral da alga. Tal fato pode estar relacionado à ocupação de $P$. capillacea no costão rochoso. Pterocladiella capillacea habita locais sombreados, preferencialmente fendas protegidas de incidência luminosa, é frequentemente encontrada no médio litoral inferior, onde fica constantemente em contato com a água. Resultados semelhantes foram obtidos por Gomez et al. (2004) analisando os padrões de fotossíntese de algas do médio litoral. Nesse estudo, os autores observaram que macroalgas coletadas no médio litoral inferior apresentaram baixos valores de Fv/Fm e Y(II), por outro lado, as macroalgas das zonas do médio litoral superior tiveram valores mais elevados de $\mathrm{Ik}$ do que as macroalgas que crescem no médio litoral ou franja do infralitoral.

Uma das primeiras mudanças evidenciadas pela incidência excessiva de luminosidade é a alteração nos níveis de pigmentos acessórios, que no caso de algas vermelhas correspondem a ficobiliproteínas e carotenoides (Schimidt et al., 2012b). Sob alta irradiância, esses pigmentos regulam a atividade fotossintetizante ao dissiparem de forma eficiente o excesso de energia através da fluorescência (Del Campo et al., 2007; Heldt et al., 2011). Adicionalmente, a localização das ficobiliproteínas e dos carotenoides na porção externa dos tilacoides facilita o desempenho na extinção de espécies reativas que poderiam danificar o aparato fotossintetizante (Schubert \& Mendoza-García, 2008). Quando a exposição à alta irradiância se torna potencialmente danosa, esses pigmentos costumam diminuir como mecanismo de fotoproteção, de 
forma a reduzir a captação de energia em excesso e evitar a fotoxidação das proteínas D1 dos fotossistemas (Adir et al., 2003).

Em termos gerais, as concentrações de pigmentos de $P$. capillacea não mostraram grandes variações entre as duas irradiâncias estudadas. Estes resultados reforçam a hipótese de que a irradiância de $300 \mu \mathrm{mol}$ fótons. $\mathrm{m}^{-2} \cdot \mathrm{s}^{-1}$ não constituiu uma condição que cause fotodano ou prejuízo para $P$. capillacea nas condições estudas, devido provavelmente à dose empregada e à alta capacidade de fotoaclimatação, produto de mecanismos eficientes de dissipação não fotoquímica.

Os resultados apresentados aqui são diferentes do observado por Torres et al. (2014) para G. tenuifrons. Os autores observaram que irradiâncias de 600 e 1000 Hmol fótons. $\mathrm{m}^{-2} \cdot \mathrm{s}^{-1}$ provocaram alterações no conteúdo de pigmentos, notado pela perda intensa de coloração nos talos. A descoloração dos ápices refletiu na diminuição dos pigmentos fotossintetizantes, principalmente das ficobiliproteínas, que são mais sensíveis à radiação. Torres et al. (2014) sugerem que esta perda de pigmentos seja uma estratégia para reduzir a absorção de luz pela alga e assim evitar a fotoxidação. Resultados semelhantes também foram obtidos em outras algas vermelhas, como em Levy \& Gantt (1988) estudando Porphyridium purpureum (Bory de Saint-Vincent) K.M. Drew \& R. Ross, Carnicas et al. (1999) analisando G. tenuistipitata C.F. Chang \& B.M. Xia, Sudatti et al. (2011) com a macroalga L. dendroidea e Serra (2013) trabalhando com G. tenuifrons.

Diferente do esperado, o conteúdo de CHN em P. capillacea permaneceu proporcional em irradiância elevada. O teor de CHN é um parâmetro que permitem elucidar o estado fisiológico da alga, visto que se relaciona com os dois principais metabolismos, o metabolismo do carbono e o metabolismo do nitrogênio. Apesar do conteúdo de CHN não ter sido alterado significativamente em $P$. capillacea em 300 $\mu$ mol fótons. $\mathrm{m}^{-2} \cdot \mathrm{s}^{-1}$, esses resultados são interessantes, pois se a taxa de crescimento se mantém elevada e a fotossíntese não sofre fotodano por períodos maiores do que oito dias, é possível estimular a taxa de produtividade de $P$. capillacea provocando uma maior incorporação de $\mathrm{C}$ e $\mathrm{N}$ e, portanto, um aumento efetivo de biomassa/produtividade. Segundo Huertas et al. (2000), além da irradiância, a disponibilidade de $\mathrm{C}$ e $\mathrm{N}$ intracelular é um fator de capital importância para o crescimento, pois esses elementos podem contribuir com processos de acúmulo de matéria orgânica e aumento da produtividade. 
Pterocladiella capillacea tem muitos pigmentos antenas que captam energia, mas o pouco da energia incidente já é o suficiente para ela crescer bem. Estes dados são relevantes, pois em experimentos futuros seria interessante estudar a perfomance fisiológica frente a condição de luminosidade de $300 \mu \mathrm{mol}$ fótons. $\mathrm{m}^{-2} . \mathrm{s}^{-1}$ a longo prazo ou associada com diferentes concentrações de nutrientes, a fim de que haja tempo para que o crescimento evidencie a produtividade e consequentemente, acúmulo de pigmentos, proteínas e outras biomoléculas de interesse aplicado.

Os resultados dos espectros de absorção e conteúdo de proteínas de $P$. capillacea não se mostraram alterados pelo aumento de irradiância, no entanto, evidenciaram interessantes potencialidades. Por exemplo, os extratos tamponados de P. capillacea mostraram absorção máxima nos comprimentos de onda entre 300 e 360 nm, resultados que podem se relacionar à presença de aminoácidos do tipo micosporinas (MAAs), compostos altamente eficientes na proteção contra radiação UV, que possuem máxima absorção neste intervalo da faixa espectral (Cardozo, 2007). Tal resultado é condizente com que a literatura mostra, pois dentre os grandes grupos de macroalgas estes aminoácidos são majoritariamente encontrados em algas vermelhas (Singh et al., 2008). Por sua vez, o aumento de proteínas solúveis totais ao longo do tempo poderia ser estimulado sob $300 \mu \mathrm{mol}$ fótons. $\mathrm{m}^{-2} . \mathrm{s}^{-1}$ desde que o período de cultivo seja maior, visto que a síntese de proteínas ocorre a médio (dias a semanas) e longo prazo (meses). Em macroalgas, o teor de proteínas solúveis totais parece estar diretamente ligado à disponibilidade de nutriente e não necessariamente à irradiância. Andria et al. (1999) observaram que o conteúdo de proteínas solúveis totais de Gracilaria sp. diminuiu quando a espécie foi cultivada com pouca disponibilidade de nitrogênio, resultados semelhantes foram observados por Cóllen et al. (2004) com Gracilaria tenuistipitata. Em contrapartida, as linhagens verde-clara e marrom da macroalga vermelha Hypnea musciformis (Wulfen) J.V. Lamouroux acumularam proteínas com o aumento da concentração de nitrato (Martins et al., 2009). Dessa forma, P. capillacea poderia ser utilizada como espécie alvo para o acúmulo de proteínas e MAAs, visando a utilização desses compostos como ingredientes funcionais.

Foi possível evidenciar pelos dados de PCA que os tratamentos 60 e $300 \mu \mathrm{mol}$ fótons. $\mathrm{m}^{-2} \cdot \mathrm{s}^{-1}$ influenciaram de forma diferente as respostas de $P$. capillacea, na qual o aumento de irradiância foi capaz de alterar o comportamento fisiológico de $P$. capillacea. A espécie mostrou fotossensibilidade frente à maior irradiância, porém, os 
resultados não mostraram evidências de fotodano, indicando eficientes respostas de tolerância mediante a dissipação não fotoquímica não regulada.

Os resultados aqui expostos indicam a possibilidade de estimular a taxa de crescimento sob condições laboratoriais de PAR. Esta resposta é de interesse aplicado, pois pode ser aproveitada para aumentar a produtividade de um sistema de cultivo mediante o incremento da irradiância, além de, estimular a produção e acúmulo de certas substâncias de interesse mediante o estímulo do crescimento. No entanto, a intensidade, assim como a duração da PAR é capaz de promover fotoinibição em organismos fotossintetizantes e provocar efeitos deletérios. Dessa forma, cabe ressaltar a importância de acompanhar os níveis de fotoaclimatação e fotoinibição em condições laboratoriais, mensurando o conteúdo pigmentar, especialmente em situações de longo prazo de exposição, a fim de não sobrecarregar o sistema de captura e utilização de energia, o que poderia resultar em perdas na produtividade.

A compreensão da fisiologia e respostas ecológicas de macroalgas frente à energia luminosa é de fundamental importância para explicar o seu comportamento fisiológico in situ e prever consequências ecológicas em ecossistemas costeiros como resultado do aumento da irradiância e radiação UV devido a redução da camada de ozônio. A alta eficiência em fotoaclimatação e a necessidade de pouca intensidade luminosa para seus processos vitais coincidem com a posição de $P$. capillacea no costão rochoso, que pode determinar o seu desempenho fisiológico, como reportado para os ecótipos (sol/sombra) das rodófitas Gelidium J.V. Lamouroux (Gómez \& Figueroa, 1998) e Porphyra (Figueroa et al., 2003b).

Neste estudo, dada a capacidade de P. capillacea para aclimatar seu desempenho fotossintético à irradiância, sugere-se investigar outras possíveis alterações ambientais como o aumento de temperatura e disponibilidade de nutriente, tais resultados teriam importantes implicações ecofisiológicas para o cultivo da espécie. 


\section{Referências bibliográficas}

Adir N.; Zer H.; Schochat S.; Ohad I. 2003. Photoinhibition - a historical perpective. Photosynth. Res. 76: 343-370.

Andria JR.; Vergara JJ.; Perez-Llorens JL. 1999. Biochemical responses and photosynthetic performance of Gracilaria sp. (Rhodophyta) from Cádiz, Spain, cultured under different inorganic carbon and nitrogen levels. Eur. J. Phycol. 34: 497-504.

Asada K. 1994 Mechanisms for scavenging reactive molecules generated in chloroplasts under light stress. In: Baker NR.; Bowyer JR. (eds), Photoinhibition of photosynthesis: from molecular mechanisms to the field. Bios. Sci. Publications. Oxford, 129-142.

Beach KS.; Smith CM.; R. Okano. 2000. Experimental analysis of rhodophyte photoacclimation to PAR and UV-radiation using in vivo absorbance spectroscopy. Bot. Mar. 43: 525-536.

Bouzon ZL.; Chow F.; Zitta CS.; Santos RW.; Ouriques LC.; Felix MRL.; Polo LK.; Gouveia C.; Martins RP.; Latini A.; Ramlov F.; Maraschin M.; Schmidt EC. 2012. Effects of natural radiation, photosynthetically active radiation and artificial ultraviolet radiation-B on the chloroplast organization and metabolism of Porphyra acanthophora var. brasiliensis (Rhodophyta, Bangiales). Microsc. Microanal. 18: 1467-1479.

Bradford M. 1976. A rapid sensitive method for the quantification of microgram quantities of protein utilizing the principle of protein-dye binding. Anal. Biochem.72: 248-254.

Cardozo KHM. 2007. Estudos de compostos fotoprotetores da radiação ultravioleta em algas: aminoácidos tipo micosporinas (MAAs). Tese de doutorado. Instituto de Química. Universidade de São Paulo. São Paulo. 173p.

Carnicas E.; Jimenez C.; Niell F.X. 1999. Effects of changes of irradiance on the pigment composition of Gracilaria tenuistipitata var. liui Zhang et Xia. J. Photoch. Photobiol. B. 50: 149-158.

Copertino MS.; Cheshire A.; Watling J. 2006. Photoinhibition and photoacclimation of turf algal communities on a temperate reef, after in situ transplantation experiments. J. Phycol. 42:580-592. 
CPTEC. 2016. Centro de Previsão de Tempo e Estudos Climáticos - Disponível em < http://satelite.cptec.inpe.br/repositorio7/goes13/rad_sol_web/low_res_ams_gif/201 6/01/S11236698_201601310000.gif;http://satelite.cptec.inpe.br/repositorio7/goes13 /rad_sol_web/low_res_ams_gif/2015/07/S11236698_201507310000.gif> Acesso em 29/03/2016.

Del Campo JÁ.; García-Gonzales M.; Guerrero MG. 2007. Outdoor cultivation of microalgae for carotenoid production: current states and perspectives. Apll. Microbiol. Biot. 74: 1763-1774.

Dring MJ. 1990. Light harvesting and pigment composition in marine phytoplankton and macroalgae. In: Herring PJ.; Campbell AK.; Whitfield M.; Maddock L. (eds), Light and life in the sea. Cambridge Univers. Press, Cambridge, pp. 89-103.

Donkor VA.; Hader DP.1996. Effects of ultraviolet irradiation on photosynthtic pigments in some filamentous cyanobacteria. Aquat. Microb. Ecol. 11: 143-149.

Edwards P. 1970. Illustrated guide to the seaweeds and sea grasses in the vicinity of Porto Aransas, Texas. Contr. Mar. 15: 1-228.

Falkowski PG. 1980. Light-shade adaptation in marine phytoplankton. In Falkowski PG. (ed), Primary. Production. in the Sea. Plenum Press, New York, 531p.

Figueroa FL.; Conde-Alvarez R.; Gomez I. 2003a. Relations between electron transport rates determined by pulse amplitude modulated chlorophyll fluorescence and oxygen evolution in macroalgae under different light conditions. Photosynthesis Res. 75: 259-75.

Figueroa FL.; Escassi L.; Perez-Rodríguez E.; Korbee N.; Giles AD.; Johnsen G. 2003b. Effects of short-term irradiation on photoinhibition and accumulation of mycosporine-like amino acids in sun and shade species of the red algal genus Porphyra. J. Photochem. Photobio. B. 69: 21-30.

Franklin LA.; Larkum AWD. 1997. Multiple strategies for a high light existence in a tropical marine macroalga. Photosynthesis Res. 53: 149-159.

Franklin LA.; Osmond CB.; Larkym AWD. 2003. Photoinhibition, UV-B andalgal photosynthesis. Kluwer Academic. Publishers. 352-375.

Gal-Or S.; Israel A. 2004. Growth responses of Pterocladiella capillacea (Rhodophyta) in laboratory and outdoor cultivation. J. Appl. Phycol. 16: 195-202. 
Gómez I.; Figueroa FL. 1998. Effects of UV stress on chlorophyll fluorescence kinetics of intertidal macroalgae from southern Spain: a case study in Gelidium species. $J$. Appl. Phycol. 10: 285-294.

Gomez I.; López-Figueroa F.; Ulloa N.; Morales V.; Lovengreen C.; Huovinen P.; Hess S. 2004. Patterns of photosynthesis in 18 species of intertidal macroalgae from southern Chile. Mar. Ecol. Prog. Ser. 270: 103-116.

Grobbelaar JU.; Kurano N. 2003. Use of photoacclimation in the design of a novel photobioreactor to achieve high yields in algal mass cultivation. J. Appl. Phycol. 15: $121-126$.

Grzymski J.; Johnsen G.; Sakshug E. 1997 The significance of intracellular self-shading on the bio-optical properties of brown, red and green macroalgae. J. Appl. Phycol. 33: $408-414$.

Hanelt D.; Hawes I.; Rae R. 2006. Reduction of UV-B radiation causes an enhancement of photoinhibition in high light stressed aquatic plants from New Zealand lakes. $J$. Photoch. Photobio. B. 84:89-102.

He LH.; Wu M.; Qian PY.; Zhu, MY. 2002. Effects of co-culture and salinity on the growth and agar yield of Gracilaria tenuistipitata var. liui Zhang et Xia. Chin. J. Oceanol. Limn. 20: 365-370.

Heldt H-W. 2011. Plant Biochemistry. Fourth edition. Elsevier. 618 p.

Hideg E.; Spetea C.; Vass I. 1994. Singlet oxygen and free-radical production during acceptor-induced and donor-side-induced photoinhibition - studies with spintrapping EPR spectroscopy. BBA - Bioenergenetics 1186: 143-152.

Huertas E.; Monteiro O.; Lubian LM. 2000. Effects of dissolved inorganic carbon avaibility on growth, nutrient uptake and chlorophyll fluorescence of two species of marine microalgae. Aquacult. Eng. 22: 181-197.

Iha C. 2014. Diversidade de Gelidiales (Rhodophyta) baseada em marcadores moleculares e estudos morfoanatômicos para região sudeste do Brasil. Dissertação de Mestrado. Instituto de Biociências. Universidade de São Paulo. São Paulo. 142p.

Jassby AD.; Platt T. 1976. Mathematical formulation of the relationship between photosynthesis and light for phytoplankton. Limnol. Oceanogr. 21: 540-547.

Kursar TA.; Van der Meer J.; Alberte RS. 1983. Light-harvesting system of the red alga Gracilaria tikvahiae. I. Biochemical analyses of pigments mutation. Plant Physiol. 73: 353-360. 
Lee TM.; Shiu CT. 2009. Implications of mycosporine-like amino acid and antioxidant defences in UV-B radiation tolerance for the algae species Pterocladiella capillacea and Gelidium amansii. Mar. Environ. Res. 67: 8-16.

Levy I.; Gantt E. 1988. Light acclimation in Porphyridium purpureum (Rhodophyta): growth, photosynthesis, and phycobilisomes. J. Appl. Phycol. 24: 452-458.

Lichtenthaler HK.; Buschmann C. 2001. 'Chlorophylls and carotenoids: measurement and characterization by UV-VIS spectroscopy', in 'Current protocols in food analytical chemistry' 431-438p.

MacIntyre HL.; Kana TM.; Geider RJ. 2000. The effect of water motion on short-term rates of photosynthesis by marine phytoplankton. Trends Plant Sci. 5: 12-17.

Martins AP.; Chow F..; Yokoya NS. 2009. Ensaio in vitro da enzima nitrato redutase e efeito da disponibilidade de nitrato e fosfato em variantes pigmentares de Hypnea musciformis (Wulfen) J. V. Lamour. (Gigartinales, Rhodophyta). Revista Brasil. Bot. 32: 635-645.

Maxwell K.; Johnson GN. 2000. Chlorophyll fluorescence - a practical guide. J. Exp. Bot. 51: 659-668.

Mercado JM., Jiménez C.; Niell FX.; Figueroa FL. 1996. Comparison of methods for measuring light absorption by algae and their application to the estimation of package effect. Sci. Mar. 60: 39-45.

Millar AJK.; Freshwater DW. 2005. Morphology and molecular phylogeny of the marine algal order Gelidiales (Rhodophyta) from New South Wales, including Lord Howe and Norfolk Island. Aust. Syst. Bot. 18: 215-263.

Navarro NP.; Mansilla A. Plastino EM. 2010. Iridaea cordata (Gigartinales, Rhodophyta): responses to artificial UVB radiation. J. Appl. Phycol. 22: 385-394.

Necchi O Jr. 2005. Light-related photosynthetic characteristic of freshwater rhodophytes. Aquat. Bot. 82:193-20.

Nishiyama Y.; Allakhverdiev S.; Yamamoto H.; Hayashi H.; Murata N. 2004. Singlet oxygen inhibits the repair of photosystem II by suppressing translation elongation of the D1 protein in Synechocystis sp. PCC 6803. Biochemistry 43: 11321-11330.

Nyvall-Cóllen P.; Camitz A.; Hancock RD.; Viola R.; Pedersén M. 2004. Effect of nutrient deprivation and resuply on metabolites and enzymes related to carbon allocation in Gracilaria tenuistipitata (Rhodophyta). J. Appl. Phycol. 40: 305-314. 
Perfeto PNM.; Dillenburg LR.; Almeida TL.; Schwarzbold A. 2004. Efeitos da temperatura, intensidade luminosa e concentração de fósforo na composição química de Gelidium crinale (Turner) Lamouroux (Rhodophyta, Gelidiaceae). Biociências 12: 3-10.

Ramus J.; Rosenberg G. 1980. Diurnal photosynthetic performance of seaweeds measured under natural conditions. Mar. Biol. 56: 21-28.

Rohácek K. 2002. Chlorophyll fluorescence parameters: the definitions, photosynthetic meaning, and mutual relationships. Photosynthesis Res. 40: 13-29.

Santelices B. \& Hommersand M. 1997. Pterocladiella, a new genus in the Gelidiaceae (Gelidiales, Rhodophyta). Phycologia. 36:114-119.

Santelices B. 1998. Taxonomic review of the species of Pterocladia (Gelidiales, Rhodophyta). J. Phycol. 10: 237-252.

Santos RW.; Schmidt ÉC.; Martins RP.; Latini A.; Maraschin M.; Horta PA.; Bouzon ZL. 2012. Effects of cadmium on growth, photosynthetic pigments, photosynthetic performance, biochemical parameters and structure of chloroplasts in the agarophyte Gracilaria domingensis (Rhodophyta, Gracilariales). Am. J. Plant Sci. 3: 1077-1084.

Serra DR. 2013. Resposta de Gracilariopsis tenuifrons (Gracilariales - Rhodophyta) a estímulos de irradiância in vitro. Dissertação de mestrado. Instituto de Biociências, Universidade de São Paulo, São Paulo. 97p.

Singh SP.; Kumari RP.; Rastogi KL.; Singh R.; Sinha P. 2008. Mycosporine-like amino acids (MAAs): chemical structure, biosynthesis and significance as UVabsorbing/screening compounds. Indian J. Exp. Biol. 46: 7-17.

Sudatti DB.; Fujii MT.; Rodrigues SV.; Turra A.; Pereira RC. 2011. Effects of abiotic factors on growth and chemical defenses in cultivated clones of Laurencia dendroidea J. Agardh (Ceramiales, Rhodophyta). Mar. Biol. 158: 1439-1446.

Schmidt EC.; Santos R.; Horta PA.; Maraschin M.; Bouzon ZL. 2010. Effects of UVB radiation on the agarophyte Gracilaria domingensis (Rhodophyta, Gracilariales): Changes in cell organization, growth and photosynthetic performance. Micron 41: 919-930.

Schmidt EC.; Pereira B.; Mansur-Lessa C.; Santos R.; Scherner F.; Horta PA.; Martins RP.; Latini A.; Maraschin M.; Bouzon ZL. 2012a. Alterations in architecture and 
metabolism induced by ultraviolet radiation-B in the carragenophyte Chondracanthus teedei Rhodophyta, Gigartinales. Protoplasma. 249: 353-367.

Schmidt EC.; Santos RW. dos; Faveri C de; Horta PA.; Martins R. de P.; Latini A.; Ramlov F.; Maraschin M.; Bouzon ZL. 2012b. Response of the agarophyte Gelidium floridanum after in vitro exposure to ultraviolet radiation B: changes in ultrastructure, pigments, and antioxidant systems. J. Appl. Phycol. 24: 1341-1352.

Schreiber U; Schliwa U; Bilger W. 1986. Continuous recording of photochemical and non-photochemical chlorophyll fluorescence quenching with a new type of modulation fluorometer. Photosynthesis. Res. 10: 51-62.

Schreiber U.; Neubauer C. 1990. $\mathrm{O}_{2}$-dependent electron flow, membrane energization and the mechanism of non-photochemical quenching of chlorophyll fluorescence. Photosynthesis Res. 25: 279-293.

Schubert N.; Mendoza-García E. 2008. Photoinhibition in red algal species with different carotenoid profiles. J. Phycol. 44: 1437-1446.

Takahashi S.; Murata N. 2008. How do environmental stress accelerate photoinhibition?

Trends Plant. Sci. 3: 178-182.

Tala F.; Chow F. 2014. Phenology and photosynthetic performance of Porphyra spp.

(Bangiophyceae, Rhodophyta): seasonal and latitudinal variation in Chile. Aquat. Bot. 113: 107-116.

Torres BP; Chow F.; Santos DYAC. 2014. Growth and photosynthetic pigments of Gracilariopsis tenuifrons (Rhodophyta, gracilariaceae) under high light in vitro culture. J. Appl. Phycol. 27: 1243-1251.

Ursi S.; Plastino EM. 2001. Crescimento in vitro de linhagens de coloração vermelha e marrom-esverdeada clara de Gracilaria sp. (Gracilariales, Rhodophyta) em dois meios de cultura: análise de diferentes estádios reprodutivos. Rev. Bras. Bot. 24: 587-594.

Wanderley A. 2009. Influência da disponibilidade de nitrato sobre crescimento, atividade da nitrato redutase, composição química e captação de nitrato e fosfato em Gracilariopsis tenuifrons (Gracilariales, Rhodophyta). Dissertação de mestrado. Instituto de Biociências. Universidade de São Paulo, São Paulo. 140 p.

Wang Y.; Wang Y.; Zhu L.; Zhou B.; Tang X. 2012. Comparative studies on the ecophysiological differences of two green tide macroalgae under controlled laboratory conditions. Plos One 7: 1-15. 
Yakovleva IM.; Titlyanov EA. 2001. Effect of high visible and UV irradiance on subtidal Chondrus crispus: stress photoinhibition and protective mechanisms. Aquat. Bot. 71:47-61.

Zou D.; Kunshan G. 2014. Temperature of photosynthetic light and carbon use characteristics in the red seaweed Gracilariopsis lemaneiformis (Gracilariales, Rhodophyta). J. Appl. Phycol. 50: 366-375.

Zubia M.; Freile-Pelegrin Y.; Robledo D. 2014. Photosynthesis, pigment composition and antioxidant defences in the red alga Gracilariopsis tenuifrons (Gracilariale, Rhodophyta) under environmental stress. J. Phycol. 26: 2001-2010.

Zhu L.; Xiao H.; Wang Y.; Jian X.; Zhang Z.; Zhang H.; Tang X. 2015. Physiological responses of macroalga Gracilaria lemaneiformis (Rhodophyta) to UV-B radiation exposure. Chin. J. Oceanol. Limn. 33: 389-399. 


\title{
Capítulo II
}

\section{Variação do potencial antioxidante na alga vermelha Pterocladiella capillacea (Rhodophyta, Gelidiales) submetida a diferentes irradiâncias}

\author{
Variation of antioxidant potential in the red alga Pterocladiella \\ capillacea (Rhodophyta, Gelidiales) under to different irradiances
}

\begin{abstract}
Resumo
Os costões rochosos estão sujeitos às variações de intensidades luminosas, as macroalgas sofrem com a ação de baixas e altas irradiâncias, principalmente aquelas que habitam a zona do médiolitoral, em condições extremas essas alterações podem causar estresse oxidativo. Nesse contexto, a sobrevivência do organismo depende de mecanismos antioxidantes eficientes para eliminar os efeitos danosos desse estresse, a avaliação da ação antioxidante de uma espécie é fundamental para conhecer sua sensibilidade frente a condições ambientais. O objetivo da pesquisa foi caracterizar a influência da radiação fotossinteticamente ativa (PAR) sobre o potencial antioxidante da agarófita Pterocladiella capillacea através de cinco ensaios in vitro: sequestro dos radicais DPPH e ABTS, capacidade redutora do Folin-Ciocalteu, atividades quelante e redução de ferro sob influência de duas irradiâncias: 60 e $300 \mu \mathrm{mol}$ fótons.m $\mathrm{m}^{-2} . \mathrm{s}^{-1}$. O aumento da atividade antioxidante pela captura do radical livre ABTS indicou que os talos de $P$. capillacea apresentaram maior capacidade de sequestro de espécies reativas com o aumento da irradiância. Pterocladiella capillacea apresenta poder redutor naturalmente através do método do Folin Ciocalteu, independente da intensidade de luz. No ensaio da redução do ferro (FRAP), a atividade antioxidante de $P$. capillacea foi aumentada pelo estímulo de luz. Dessa forma, esses resultados indicam que $P$. capillacea possui capacidade antioxidante para os métodos do ABTS, Folin-Ciocalteu e FRAP. Sugere-se aprofundar os estudos a fim de avaliar a capacidade bioativa desta espécie.
\end{abstract}




\begin{abstract}
The rocky shores are under the changes in light intensities, the macroalgae can suffer with the action of lows and highs irradiances, especially those that live in the intertidal zone, in extreme conditions these changes can cause oxidative stress. In this context, the survival of the organism depends on effective antioxidant mechanisms to eliminate the harmful effects of stress, evaluation of the antioxidant activity is essential to know its sensitivity to environmental conditions. The objective of the research was to characterize the influence of photosynthetically active radiation (PAR) on the antioxidant potential of agarophyte Pterocladiella capillacea through five in vitro assays: kidnapping of DPPH and ABTS radical, the reducing capacity of Folin-Ciocalteu, chelating activities and reduction of iron under the influence of two irradiances: 60 and $300 \mu$ mol fótons.m ${ }^{-}$ ${ }^{2} \cdot \mathrm{s}^{-1}$. The increase in antioxidant activity by capturing free radical ABTS indicated that $P$. capillacea thallus had higher sequestration capacity of reactive species by increasing the irradiance. Pterocladiella capillacea features reducing power through the method of Folin Ciocalteu, regardless of the intensity of light. In the assay of reduced iron (FRAP), the antioxidante activity of $P$. capillacea was higher with the increase of light. Thus, these results indicated that $P$. capillacea has antioxidant capacity to the assays ABTS, Folin-Ciocalteu and FRAP. It is suggested further studies to evaluate the ability of bioactive compounds from $P$. capillacea.
\end{abstract}




\section{Introdução}

Os costões rochosos são ambientes de grande variação ambiental e as macroalgas que alí habitam sofrem ação de diversos fatores bióticos e abióticos. Nas regiões entremarés, as algas estão submetidas a constantes variações de intensidade de luz, temperatura, exposição ao ar (dessecamento), salinidade e concentrações de nutrientes, $\mathrm{O}_{2}$ e $\mathrm{CO}_{2}$. A combinção desses e outros fatores podem resultar em situações de desbalanço metabólico, podendo ocasionar estresse oxidativo (Matsukawa et al., 1997). O estresse oxidativo resulta do aumento da concentração de espécies altamente reativas, principalmente derivadas de oxigênio e nitrogênio, acumuladas devido à maior produção intracelular ou à deficiência dos mecanismos antioxidantes (Rijstenbil et al., 2000; Burritt et al., 2002). Condições de estresse oxidativo podem levar a diversos danos em moléculas como aminoácidos, proteínas, lipídeos e ácidos nucleicos e em estruturas como mitocôndrias e tilacoides. Estes últimos tornam-se alvo primário para os efeitos deletérios oxidativos, especialmente por conterem lipídeos não saturados como elementos estruturais majoritários (Rocha et al., 2007). Em alguns casos, esse estresse compromete os processos biológicos podendo levar à morte do organismo (Halliwell \& Whiteman, 2004; Halliwell \& Gutteridge, 2006). Para evitar os danos provocados pelo acúmulo de espécies reativas, as macroalgas precisam ter eficentes mecanismos detoxificadores, especificamente sistemas antioxidantes.

A combinação de elevadas intensidades de luz aliada a altas concentrações de oxigênio promove a formação de radicais livres e outros agente oxidantes, afetando significativamente o metabolismo das macroalgas. A ausência de danos oxidativos nos componentes estruturais como cloroplastos, membranas, mitocôndrias e a estabilidade metabólica desses organismos, são indicativos de eficientes mecanismos fotoprotores que estariam relacionadas com a presença de substâncias antioxidantes (Gupta \& AbuGhannam, 2011; Souza et al., 2011; Chakraborty et al., 2015).

Apesar da importância, poucos trabalhos são encontrados na literatura com relação ao efeito de irradiância e produção de antioxidantes em macroalgas. Aguilera et al. (2002), avaliaram a atividade de enzimas antioxidantes de algas que ocupavam diferentes porções na zonação. Algas do médio litoral superior, expostas a maior incidência de luz e exposição ao ar, tiveram maior atividade de enzimas antioxidantes em comparação com espécies do médio litoral inferior, indicando uma proteção bioquímica mais eficiente em algas expostas a maiores condições de estresse in situ. 
Resultados semelhantes foram descritos por Choo et al. (2004), no qual os autores verificaram que o aumento na produção de antioxidantes em duas macroalgas verdes foi correlacionado positivamente com o aumento de intensidade luminosa. Na macroalga verde Ulva fasciata Delile, Shiu \& Lee (2005) relataram que a espécie foi eficiente em regular a ação dos sistemas antioxidantes e indução da atividade de enzimas antioxidantes para desintoxicar espécies reativas de oxigênio (EROs) sob influência de intensidades crescente de radiação. Comparando o potencial antioxidante de duas Gelidiales, Pterocladiella capillacea (S.G. Gmelin) Santelices \& Hommersand e Gelidium amansii (J.V. Lamouroux) J.V. Lamouroux, Lee \& Shiu (2009) verificaram que $G$. amansii sofreu maior estresse oxidativo quando exposta a radiação, enquanto $P$. capillacea foi capaz de reduzir sua sensibilidade frente à radiação através do aumento na produção de antioxidantes. Polifenóis são compostoas com conhecida ação antioxidante e característica de muitas algas pardas. Guarino (2003), estudando a alga parda Stypopodium zonale (J.V. Lamouroux) Papenfuss, observou que a manipulação de irradiância não promoveu alterações nos teores de polifenóis. No entanto, o incremento de luz promoveu aumento no teor de biomassa. Diferentemente, Torres (2012) observou que houve um aumento no teor de fenóis totais na alga vermelha Gracilariopsis tenuifrons (C.J. Bird \& E.C. Oliveira) Fredericq \& Hommersand com a maior exposição a altas intensidades luminosas, sugerindo que a produção de compostos fenólicos pode ter sido um mecanismo de fotoproteção para essa espécie.

O conhecimento dos mecanismos de ativação e regulação do potencial antioxidante nas macroalgas é fundamental para conhecer sua sensibilidade frente a condições ambientais, com ampla aplicação na compreensão ecofisiológica, de maricultura, manejo e biotecnológica.

Do ponto de vista aplicado, o interesse pelas macroalgas como fontes de produtos naturais com elevada atividade antioxidante surge do interesse em substituir antioxidantes sintéticos como o hidroxianisol butilado (BHA) e hidroxitolueno butilado (BHT), compostos que têm demonstrado efeitos carcinogênicos (Ruperez, 2002; Cox et al., 2010). Os antioxidantes naturais podem ser adicionados aos alimentos, como um nutracêutico, para retardar a deterioração oxidativa (O'Sullivan et al., 2011), ou utilizados na prevenção de doenças crônicas (Wojcik et al., 2010). As algas desidratadas podem ser armazenadas por longos períodos sem haver deterioração oxidativa, tal fato 
desperta o grande interesse dos pesquisadores em relação ao seu mecanismo antioxidante (Rocha et al., 2007).

O objetivo desta pesquisa foi analisar a variação do potencial antioxidante de $P$. capillacea submetida à intensidade elevada de PAR e relacioná-los como possíveis mecanismos de fotoproteção frente a estresse luminoso.

\section{Material e métodos}

Pterocladiella capillacea foi coletada na primavera em setembro de 2014, na região entremarés do costão rochoso da Praia da Cruz $\left(21^{\circ} 02^{\prime} 01,68^{\prime \prime} \mathrm{S} ; 40^{\circ} 48^{\prime} 44,43^{\prime \prime} \mathrm{O}\right)$, município de Marataízes, litoral sul do Estado do Espírito Santo, Brasil, e mantidas em cultivo no Laboratório de Algas Marinhas "Édison José de Paula" do Instituto de Biociências da Universidade de São Paulo. Porções apicais entre 8-10 cm de comprimento foram aclimatadas por uma semana em condições controladas de laboratório: $25 \pm 1^{\circ} \mathrm{C}, 60 \pm 5 \mu \mathrm{mol}$ fótons. $\mathrm{m}^{-2} \cdot \mathrm{s}^{-1}$, fotoperíodo de $14 \mathrm{~h}$ de luz e $10 \mathrm{~h}$ de escuro e aeração em períodos intermitentes de 30 min ligado e 30 min desligado, em água do mar esterilizada (32 ups) enriquecida com solução de nutrientes de von Stosch (VS; Ursi \& Plastino (2001), modificado de Edwards (1970)) a uma concentração de $100 \%$, e proporção de $3 \mathrm{~g}$ de massa fresca (MF) para cada $1 \mathrm{~L}$ de meio de cultivo. Após uma semana de aclimatação, o material foi submetido por oito dias a duas condições de irradiância $(\mathrm{n}=5)$ : (a) $60 \pm 5 \mu \mathrm{mol}$ fótons. $\mathrm{m}^{-2} \cdot \mathrm{s}^{-1}$ (controle) e (b) $300 \pm 5 \mu \mathrm{mol}$ fótons. $\mathrm{m}^{-2} \cdot \mathrm{s}^{-1}$ na proporção de proporção de $1 \mathrm{~g}$ MF para cada $1 \mathrm{~L}$ de meio de cultivo. A adição de meio de cultura foi realizada antes de iniciar o experimento (tempo zero) e após uma semana de experimento. Este último com o objetivo de avaliar a capacidade de recuperação após suprimento de nutrientes. As amostras para os ensaios antioxidantes foram avaliadas nos dias 0 (inicial), 1, 3, 5, 7 e 8 (t0, t1, t3, t5, t7 e t8), com cinco réplicas em cada tempo para as duas irradiâncias.

O potencial antioxidante foi determinado por espectrofotômetro UV-visível para microplacas a partir de amostras de 200 mg MF extraídas em 1 mL de metanol ( $\mathrm{n}=5)$, mediante cinco diferentes ensaios: a) atividade sequestradora do radical DPPH (2,2difenil-1-picrilhidrazil) (Pires et al. (em preparação), modificado de Brand-Williams et al. (1995)), b) captura do radical livre ABTS (2,2-azinobis (3-etilbenzotiazolina-6-ácido sulfônico) (Torres et al. (em preparação), modificado de Rufino \& Alves (2007) e Yang et al. (2011)), c) potencial de quelar metais de ferro (Harb et al. (2016), modificado de 
Min et al. (2011)), d) capacidade redutora do Folin-Ciocalteu (Pires et al. (em preparação), adaptado de Singleton \& Rossi (1965) e Waterman \& Mole (1994)) e) poder de redução do ferro (FRAP) (Urrea-Victoria et al. (2016), modificado de Brito et al. (2006)). Cada um dos ensaios antioxidantes foi avaliado em seis concentrações de extrato bruto, sendo elas $0,6,8,10,12$ e 13,3 mg.mL $L^{-1}$, para a análise de curvas de dose-resposta de porcentagem de atividade antioxidante (AAOX) versus a concentração de extrato bruto. A partir dessas plotagens, foram calculados os valores de EC50 (concentração efetiva do extrato para reduzir em 50\% a atividade antioxidante máxima) com auxílio do programa GraphPad Prism v. 6.01, utilizando um modelo de ajuste sigmoidal de dose-resposta (Chen et al., 2013). A fim de comparar o potencial antioxidante entre os diferentes tratamentos, foi escolhida apenas a concentração de extrato bruto que apresentou maior potencial antioxidante, sendo comparadas as porcentagens de AAOX e equivalentes padrão. Resultados complementares encontramse no Anexo III.

A porcentagem de atividade antioxidante para os ensaios de Folin-Ciocalteu e FRAP foram calculadas utilizando como valor de $100 \%$ a média correspondente ao tempo inicial (t0) na concentração de $13,3 \mathrm{mg} \cdot \mathrm{mL}^{-1}$. Pois esta foi considerada como condição controle para $P$. capillacea sob a situação experimental.

Os resultados de equivalentes padrões foram aferidos utilizando curvas padrões de ácido gálico (Sigma-Aldrich, Brasil) e Trolox (Sigma-Aldrich, Brasil), segundo as concentrações (expressas em massa de padrão) e as equações apresentadas na Tabela 4.

Adicionalmente, extratos metanólicos (concentração testada $3,1 \mathrm{mg} \cdot \mathrm{mL}^{-1}$ ) e extratos tamponados (concentração testada $4,6 \mathrm{mg} \cdot \mathrm{mL}^{-1}$ ) de $P$. capillacea provenientes de extrações de pigmentos (ver maiores detalhes em Material e métodos gerais) foram também estudados no seu potencial antioxidante.

Os resultados obtidos foram analisados estatísticamente com o programa Statistica 12 e testados quanto à normalidade e homocedasticidade $(\mathrm{p}<0,05)$. A significância das médias foi analisada dentro de um intervalo de confiança de $95 \%$ (p < 0,05) com ANOVA bifatorial e teste post-hoc de comparação múltipla de NewmanKeuls (ver detalhes em Anexo III Tabelas AIII-7-14). Com o conjunto de dados foi realizada uma análise multivariada de componentes principais (PCA) e uma análise de agrupamentos hierárquicos com o auxílio do programa Past. 
Tabela 4. Relação da concentração dos padrões ácido gálico e Trolox (expressa em massa) para cada um dos ensaios estudados, com sua respectiva equação da reta e coeficiente de regressão $\left(\mathrm{R}^{2}\right)$.

\begin{tabular}{l|c|c}
\hline \multirow{2}{*}{ Ensaio } & $\begin{array}{c}\text { Ácido gálico }(\mathbf{A G}) \\
\text { Equação da reta } \\
\text { Correlação }\end{array}$ & $\begin{array}{c}\text { Trolox } \\
\text { Equação da reta } \\
\text { Correlação }\end{array}$ \\
\hline \multirow{2}{*}{ DPPH } & $0-0,9 \mathrm{mg} \mathrm{AG}$ & $0-3 \mathrm{mg}$ Trolox \\
& $\mathrm{y}=0,9499 \mathrm{x}+1,1891$ & $\mathrm{y}=-0,2473 \mathrm{x}+1,1649$ \\
& $\mathrm{R}^{2}=0,98$ & $\mathrm{R}^{2}=0,98$ \\
\hline ABTS & $0-0,45 \mathrm{mg}$ & $0-2,7 \mathrm{mg}$ \\
& $\mathrm{y}=-1,5323 \mathrm{x}+0,8622$ & $\mathrm{y}=-0,2687 \mathrm{x}+0,9103$ \\
& $\mathrm{R}^{2}=0,99$ & $\mathrm{R}^{2}=0,99$ \\
\hline \multirow{2}{*}{ Quelante de metais } & $0-0,3 \mathrm{mg}$ & ----- \\
& $\mathrm{y}=-0,2123 \mathrm{x}+1,0462$ & $0-30 \mathrm{mg}$ \\
& $\mathrm{R}^{2}=0,99$ & $\mathrm{y}=\mathrm{y}=0,0469 \mathrm{x}$ \\
Folin-Ciocalteu & $0-3 \mathrm{mg}$ & $\mathrm{R}^{2}=0,99$ \\
& $\mathrm{y}=\mathrm{y}=0,2299 \mathrm{x}$ & $0-3 \mathrm{mg}$ \\
& $\mathrm{R}^{2}=0,99$ & $\mathrm{y}=0,4628 \mathrm{x}$ \\
FRAP & $0-0,6 \mathrm{mg}$ & $\mathrm{R}^{2}=0,99$ \\
\hline
\end{tabular}

\section{Resultados}

\subsection{Percentual de atividade antioxidante e EC50}

A dinâmica do percentual de potencial antioxidante (\% AAOX) mediante sequestro do radical DPPH para as diferentes concentrações de extrato bruto de $P$. capillacea $\left(0,6,8,10,12\right.$ e 13,3 mg.mL ${ }^{-1}$ ) para $60 \mu \mathrm{mol}$ fótons. $\mathrm{m}^{-2} \cdot \mathrm{s}^{-1}$ (Fig. 21A-F) e $300 \mu \mathrm{mol}$ fótons. $\mathrm{m}^{-2} \cdot \mathrm{s}^{-1}$ (Fig. 21G-L) mostra variações abaixo do $50 \%$ de atividade antioxidante. Dessa forma, os resultados do ensaio de DPPH comparando os tratamentos de irradiância e tempo incluíram apenas resultados da concentração de 13,3 mg.mL $L^{-1}$ (ver resultados mais para frente e detalhes em Anexo III Fig. AIII 1-2). 

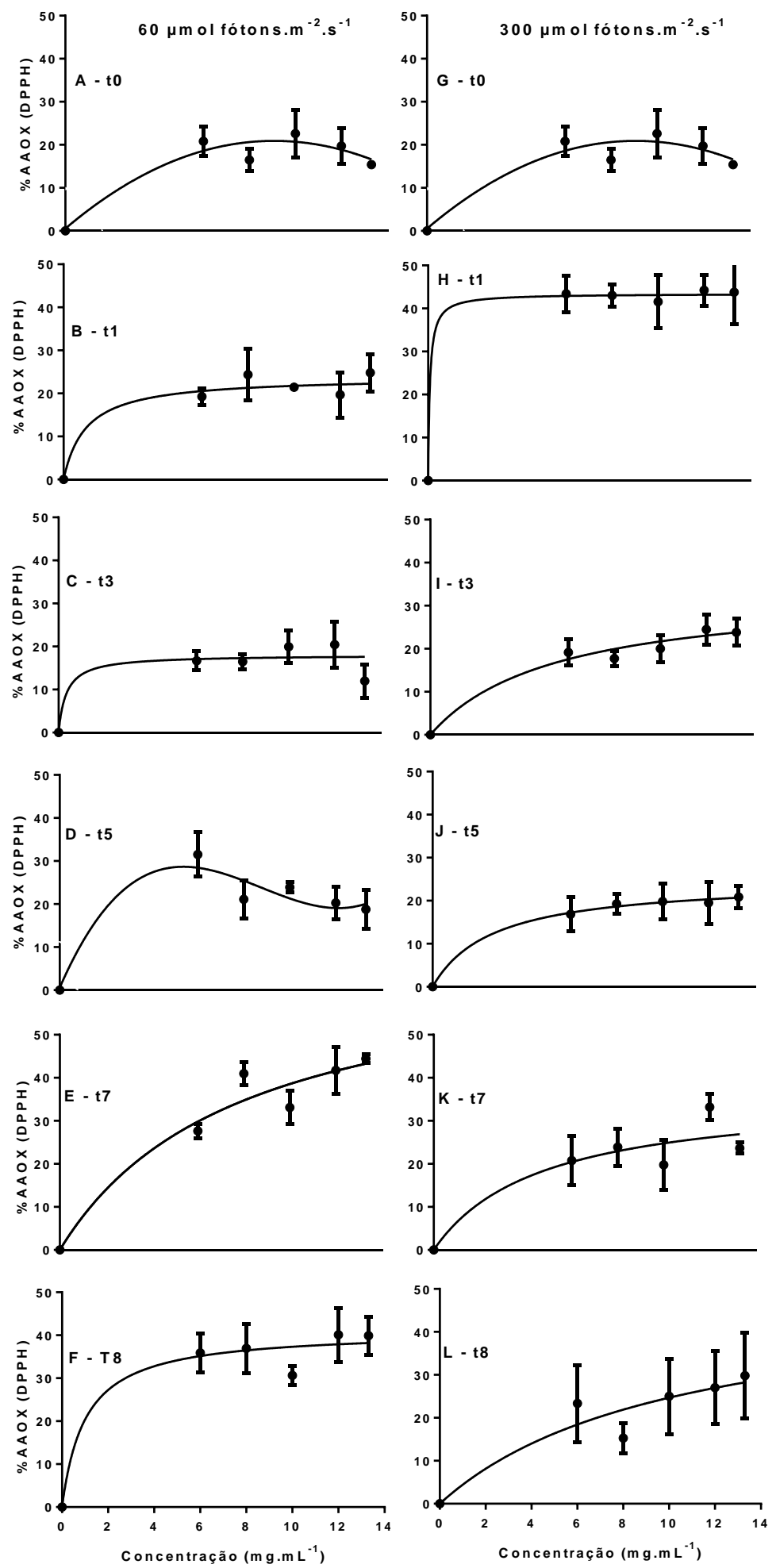

Figura 21. Porcentagem da atividade antioxidante para o sequestro do radical DPPH em Pterocladiella capillacea ao longo de oito dias de experimento (t0-t8) nas irradiâncias de 60 (A-F) e $300 \mu$ mol fótons. $\mathrm{m}^{-2} \cdot \mathrm{s}^{-1}$ (G-L). 
As curvas de porcentagem de atividade antioxidante pelo método do DPPH mostra para $60 \mu \mathrm{mol}$ fótons. $\mathrm{m}^{-2} \cdot \mathrm{s}^{-1}$ percentuais de até $30 \%$ para os tempos entre 0 e 5 dias (Fig. 21A-D), observando-se aumento acima de 30\% de atividade para os dias 7 e 8 (Fig. 21E-F, respectivamente). A tendência para extratos de $300 \mu \mathrm{mol}$ fótons. $\mathrm{m}^{-2} . \mathrm{s}^{-1}$ foi diferente, apresentando percentuais maiores nos dois primeiros tempos ( 0 e $1 \mathrm{dia})$, entre 30-40\% (Fig. 21G-H, respectivamente), e percentuais menores no decorrer do tempo de crescimento, entre 20 a 25\% (Fig. 21I-L).

Devido à baixa ação antioxidante dos extratos, não foi possível calcular o EC50 (concentração efetiva na qual o extrato bruto altera metade do efeito máximo), no entanto, foram calculados os valores de EC40 em $60 \mu \mathrm{mol}$ fótons. $\mathrm{m}^{-2} . \mathrm{s}^{-1}$ e EC20 em 300 $\mu \mathrm{mol}$ fótons. $\mathrm{m}^{-2} . \mathrm{s}^{-1}$, tais resultados referem-se aos tempos finais de cada irradiância. A Figura 22 mostra uma comparação dos dados de EC50 de macroalgas vermelhas para o ensaio do DPPH. 


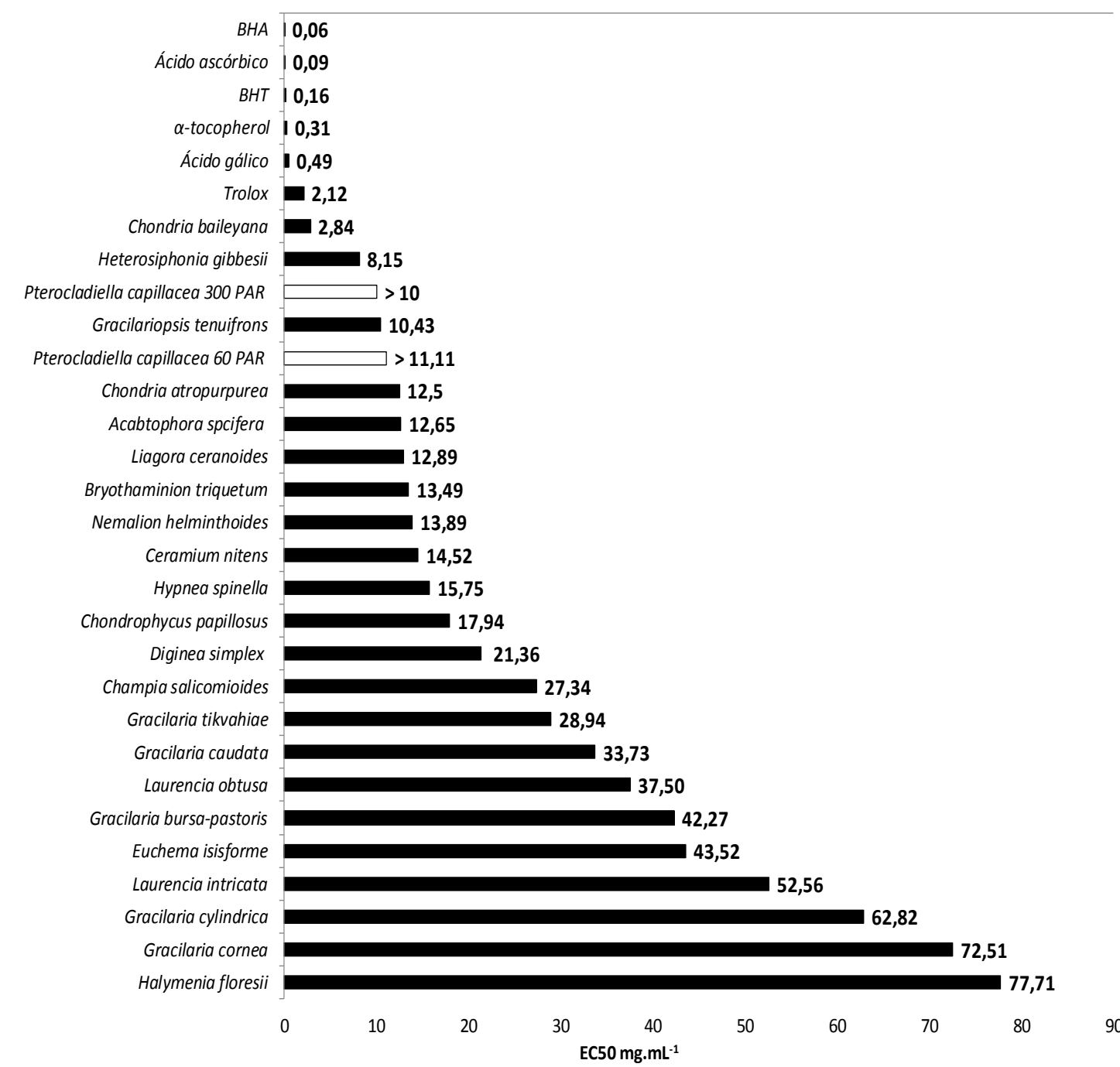

Figura 22. Sequestro do radical DPPH expressos como EC50 para algas vermelhas. As barras pretas correspodem aos valores de EC50 para os padrões ácido gálico e Trolox. Os valores de Pterocladiella capillacea em 60 e $300 \mu \mathrm{mol}$ fótons. $\mathrm{m}^{-2} \cdot \mathrm{s}^{-1}$ referem-se, respectivamente, ao EC40 e EC20 ao final do experimento (tempo 8) (Modificado de Zubia \& Roblelo, 2007).

\begin{abstract}
ABTS
O potencial antioxidante de captura do radical ABTS de extratos metanólicos de P. capillacea para os diferentes tempos de exposição e irradiâncias foram avaliados em concentrações de $0,6,8,10,12$ e 13,3 mg.mL ${ }^{-1}$. A estabilidade da curva de dosagem foi alcançada em $12 \mathrm{mg} \cdot \mathrm{mL}^{-1}$. Uma vez que a máxima atividade foi alcançada em 12 $\mathrm{mg} \cdot \mathrm{mL}^{-1}$ de extrato algáceo, a porcentagem de atividade antioxidante e equivalência em
\end{abstract}


padrão foram apresentadas apenas para esta concentração (ver detalhes em Anexo III Fig. AIII 3-4).

As curvas de porcentagem de atividade antioxidante para ensaio do radical ABTS mostra para $60 \mu \mathrm{mol}$ fótons. $\mathrm{m}^{-2} . \mathrm{s}^{-1}$ percentuais de até $70 \%$ para os tempos entre 0 e 8 dias (Fig. 23A-F), registrando-se maior atividade nos tempos finais 7 e 8 (Fig. 23EF). A tendência em $300 \mu \mathrm{mol}$ fótons. $\mathrm{m}^{-2} \cdot \mathrm{s}^{-1}$ não variou muito ao longo do tempo (Fig. 23G-L).

Pelo o ensaio do ABTS ter apresentado atividades antioxidantes superiores a $50 \%$ foi possível realizar o cálculo de EC50 (Fig. 23 e 24). De modo geral, em $60 \mu$ mol fótons. $\mathrm{m}^{-2} \cdot \mathrm{s}^{-1}$ foram observados maiores valores de EC50 até o tempo 3, o melhor valor de EC50 foi registrado após 7 dias sob esta intensidade de luz. Em $300 \mu$ mol fótons.m ${ }^{-}$ ${ }^{2} \cdot \mathrm{s}^{-1}$, o EC50 diminuiu a partir do t3, obtendo melhor resultado após 8 dias sob aumento de luz.

As maiores eficiências antioxidativas registradas em $60 \mu \mathrm{mol}$ fótons. $\mathrm{m}^{-2} \cdot \mathrm{s}^{-1}$ nos tempos 7 e 8 dias apresentam EC50 de 5,8 e 6,15, respectivamente, e em $300 \mu$ mol fótons. $\mathrm{m}^{-2} . \mathrm{s}^{-1}$ nos tempos 3,5 e 8 dias foram 5,$98 ; 5,98 ; 4,40$ respectivamente.

Comparando as duas irradiâncias, foi possível verificar que o aumento de luz induziu menores valores de EC50 em quase todos os tempos, o menor e melhor valor de EC50 (4,40 no t8 de $300 \mu \mathrm{mol}$ fótons. $\mathrm{m}^{-2} \cdot \mathrm{s}^{-1}$ ) foi cinco vezes superior aos padrões comerciais ácido gálico e Trolox. 

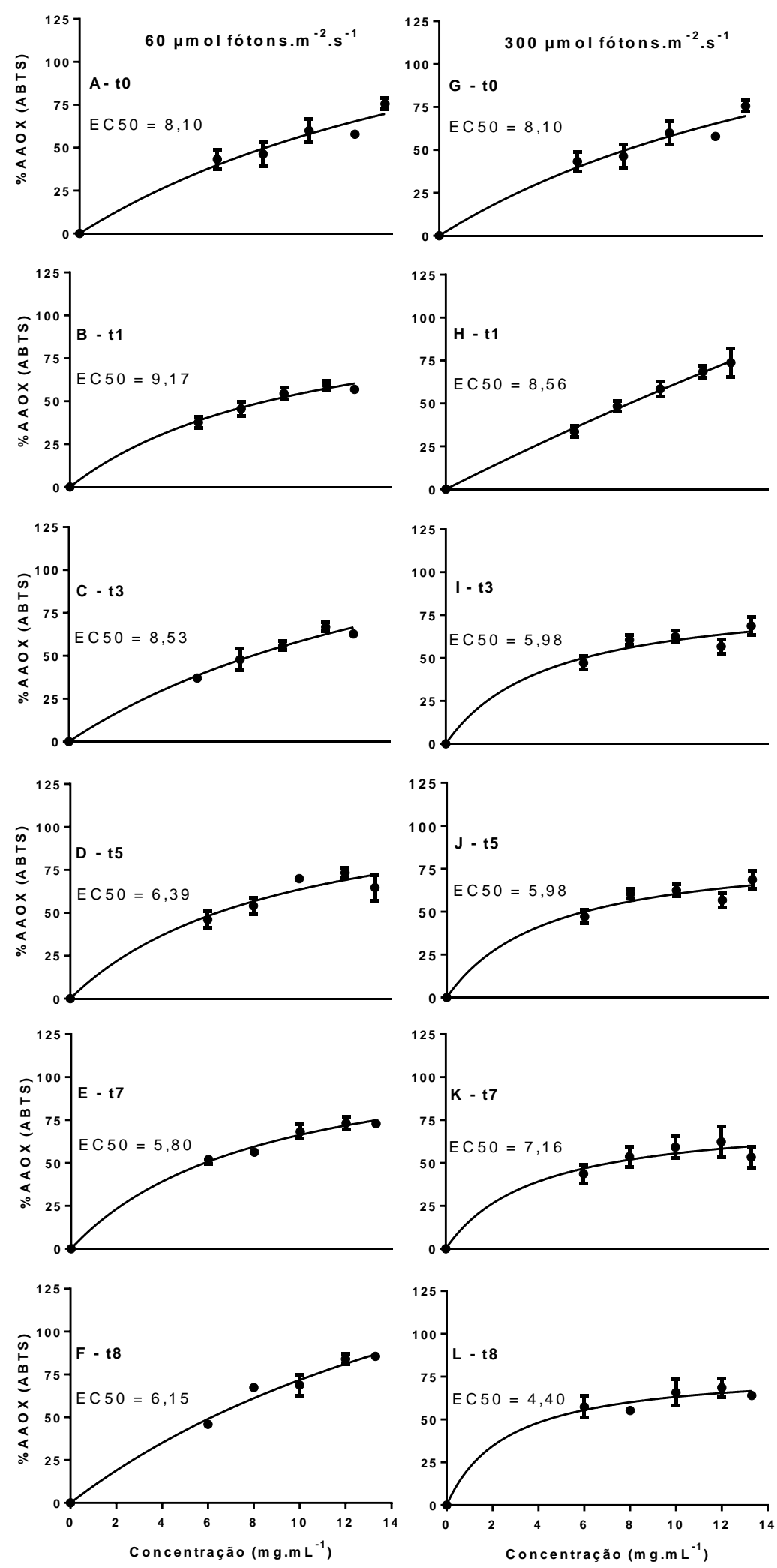

Figura 23. Porcentagem da atividade antioxidante e valores de EC50 para o ensaio ABTS em Pterocladiella capillacea ao longo de oito dias de experimento (t0-t8) nas irradiâncias de 60 (A-F) e $300 \mu \mathrm{mol}$ fótons. $\mathrm{m}^{-2} \cdot \mathrm{s}^{-1}(\mathrm{G}-\mathrm{L})$. 


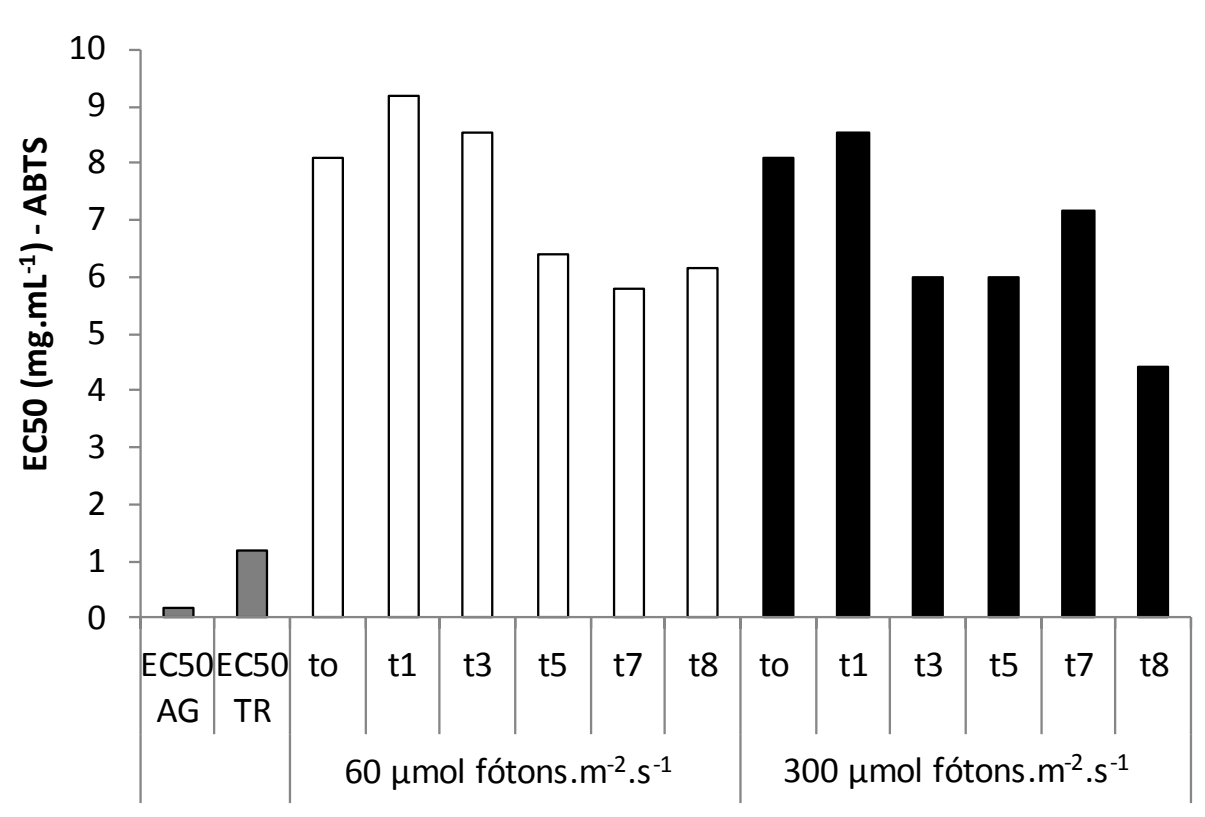

Figura 24. Valores de EC50 para o ensaio da captura do radical ABTS em Pterocladiella capillacea ao longo de oito dias de experimento nas irradiâncias de 60 e $300 \mu \mathrm{mol}$ fótons. $\mathrm{m}^{-2} . \mathrm{s}^{-1}$. As barras cinza (controle) representam o EC50 da curva padrão de ácido gálico e Trolox para o respectivo ensaio.

\section{Quelante de metais}

O potencial quelante de metais de $P$. capillacea para os diferentes tempos de exposição e irradiâncias foram avaliados em concentrações de 0, 6, 8, 10, 12 e 13,3 $\mathrm{mg} \cdot \mathrm{mL}^{-1}$. A atividade antioxidante alcançada na maior concentração de extrato bruto foi menor que 50\%, portanto, não foram cálculos os valores de EC50 (Fig. 25). Assim, a atividade quelante de metais foi representada em porcentagem de atividade atioxidante e equivalente padrão apenas para a concentração de $13,3 \mathrm{mg} \cdot \mathrm{mL}^{-1}$ de extrato algáceo detalhes em Anexo III Fig. AIII 5-6).

As curvas de porcentagem de atividade antioxidante para a atividade quelante de metais mostrou para $60 \mu \mathrm{mol}$ fótons. $\mathrm{m}^{-2} . \mathrm{s}^{-1}$ baixos percentuais ao longo de todos os tempos (Fig. 25A-F). A mesma tendência foi observada em $300 \mu \mathrm{mol}$ fótons. $\mathrm{m}^{-2} \cdot \mathrm{s}^{-1}$, não houve variação ao longo do tempo (Fig. 25G-L). 

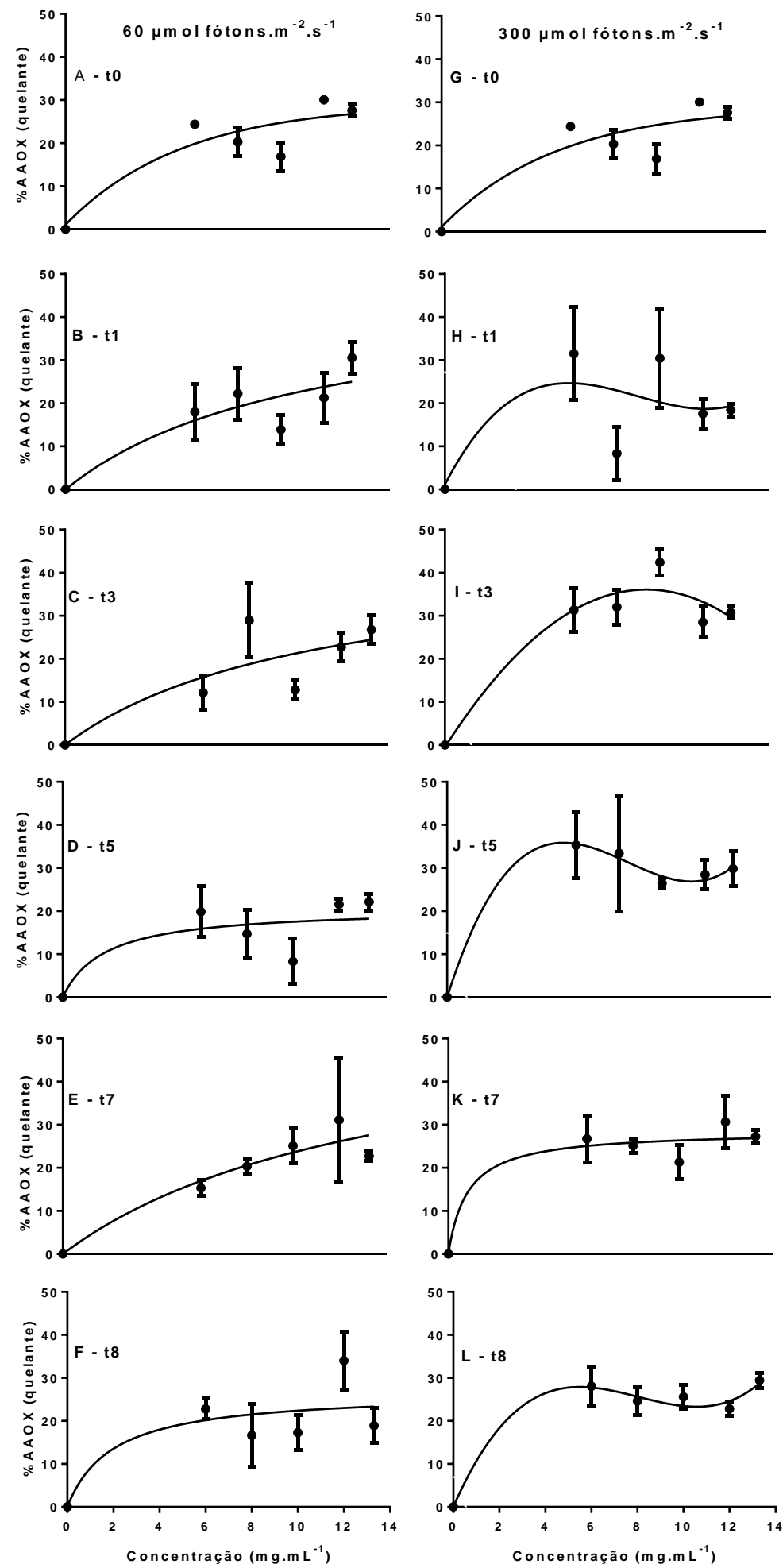

Figura 25. Porcentagem da atividade antioxidante para quelante de metais em Pterocladiella capillacea ao longo de oito dias de experimento (t0-t8) nas irradiâncias de 60 (A-F) e $300 \mu$ mol fótons.m ${ }^{-2} \cdot s^{-1}$ (G-L). 


\section{Poder redutor do Folin-Ciocalteu}

Concentrações de $0,6,8,10,12$ e $13,3 \mathrm{mg} \cdot \mathrm{mL}^{-1}$ de extrato bruto de $P$. capillacea foram avaliadas na sua capacidade antioxidante pelo método do FolinCiocalteu. A maioria das curvas de dosagem estabilizaram após $6 \mathrm{mg} . \mathrm{mL}^{-1}$ de extrato, razão pela as subsequentes análises foram calculadas entre esse intervalo (ver detalhes em Anexo III Fig. AIII 7-8).

As curvas de porcentagem de atividade antioxidante para o poder redutor do reagente Folin-Ciocalteu mostrou para $60 \mu \mathrm{mol}$ fótons. $\mathrm{m}^{-2} . \mathrm{s}^{-1}$ percentuais acima de 100 ao longo de todos os tempos (Fig. 26A-F). A mesma tendência foi observada em 300 $\mu \mathrm{mol}$ fótons. $\mathrm{m}^{-2} \cdot \mathrm{s}^{-1}$, no entanto (Fig. 26G-L).

Foi possível realizar o cálculo de EC50 para este ensaio, os valores para cada tempo/tratamento estão representados na Figura 26. Verificou-se que a irradiância de 60 $\mu$ mol fótons. $\mathrm{m}^{-2} . \mathrm{s}^{-1}$ obteve os melhores e menores valores de EC50, os valores em 60 $\mu$ mol fótons. $\mathrm{m}^{-2} \cdot \mathrm{s}^{-1}$ variaram entre 0,89 à 5,11 e para a irradiância de $300 \mu \mathrm{mol}$ fótons. $\mathrm{m}^{-2} \cdot \mathrm{s}^{-1} \mathrm{o}$ intervalo foi de 1,54 à 6,39 .

A Figura 27 mostra a comparação dos valores de EC50 com importantes padrões comerciais, ácido gálico e Trolox. Observa-se que os valores em $60 \mu \mathrm{mol}$ fótons. $\mathrm{m}^{-2} \cdot \mathrm{s}^{-1}$ equiparam-se aos valores de EC50 para ácido gálico, enquanto os dados de $300 \mu \mathrm{mol}$ fótons. $\mathrm{m}^{-2} \cdot \mathrm{s}^{-1}$ assemelham-se aos valores de EC50 para Trolox.

\section{Potencial de redução do Ferro (FRAP)}

O potencial de redução do ferro de $P$. capillacea, para os diferentes tempos de exposição e irradiâncias, foi avaliado nas concentrações de 0, 6, 8, 10, 12 e 13,3 mg.mL ${ }^{-}$

1. A máxima atividade foi alcançada em $12 \mathrm{mg} \cdot \mathrm{mL}^{-1}$, portanto a porcentagem de atividade antioxidante e a equivalência em padrão foi calculada apenas para esta concentração (ver detalhes em Anexo III Fig. AIII 9-10).

As curvas de porcentagem de atividade antioxidante para o FRAP mostrou para $60 \mu \mathrm{mol}$ fótons. $\mathrm{m}^{-2} . \mathrm{s}^{-1}$ percentuais próximos de 100 ao longo de todo período amostral (Fig. 28A-F). A mesma tendência foi observada em $300 \mu \mathrm{mol}$ fótons. $\mathrm{m}^{-2} \cdot \mathrm{s}^{-1}$ (Fig. 28GL). 

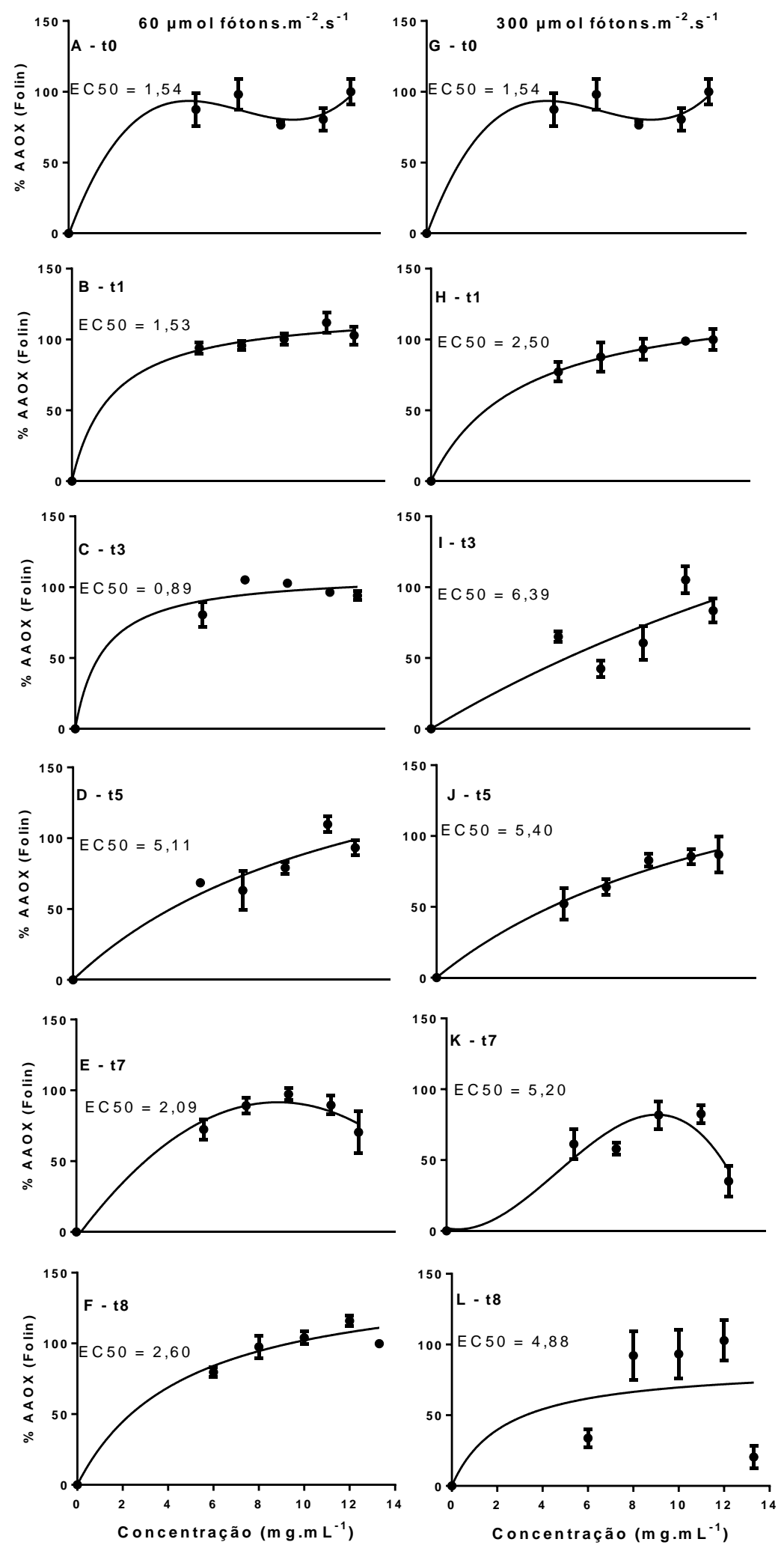

Figura 26. Porcentagem da atividade antioxidante e valores de EC50 para poder redutor do Folin-Ciocalteu em Pterocladiella capillacea ao longo de oito dias de experimento (t0-t8) nas irradiâncias de 60 (A-F) e $300 \mu$ mol fótons.m ${ }^{-2} \cdot \mathrm{s}^{-1}(\mathrm{G}-\mathrm{L})$. 


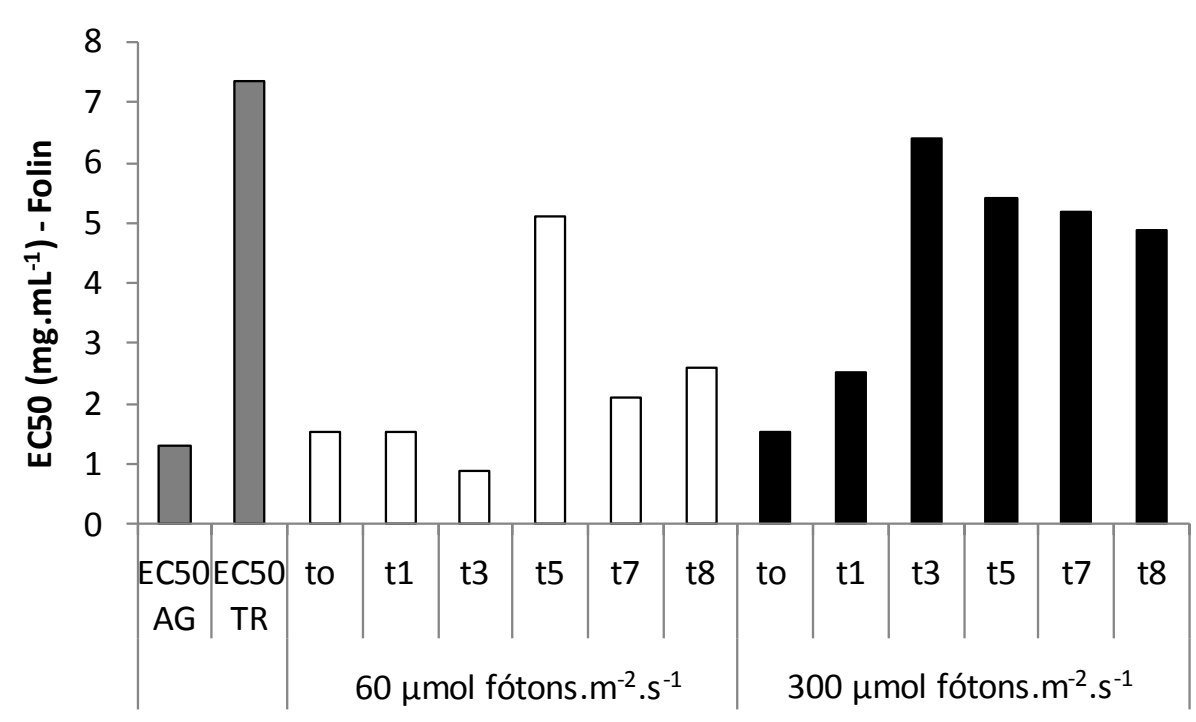

Figura 27. Valores de EC50 para o ensaio do poder redutor do Folin-Ciocalteu em Pterocladiella capillacea ao longo de oito dias de experimento nas irradiâncias de 60 e $300 \mu \mathrm{mol}$ fótons. $\mathrm{m}^{-2} \cdot \mathrm{s}^{-1}$. As barras cinzas (controle) representam o EC50 da curva padrão de ácido gálico e Trolox para o respectivo ensaio.

Os valores de EC50 para o ensaio do FRAP estão na Figura 28. Foi possível observar que a irradiância de $300 \mu$ mol fótons. $\mathrm{m}^{-2} . \mathrm{s}^{-1}$ obteve os melhores e menores valores de EC50, os valores em $60 \mu \mathrm{mol}$ fótons. $\mathrm{m}^{-2} \cdot \mathrm{s}^{-1}$ variaram entre 1,88 à 2,33 e para a irradiância de $300 \mu \mathrm{mol}$ fótons. $\mathrm{m}^{-2} \cdot \mathrm{s}^{-1} \mathrm{o}$ intervalo foi de 1,59 à 2,03.

A Figura 29 mostra a comparação dos valores de EC50 com importantes padrões comerciais, ácido gálico e Trolox. De modo geral, foi possível verificar que não houve grandes variações ao longo do tempo, nem entre as irradiâncias. Os valores equiparamse ao dobro do EC50 de ácido gálico e metade do EC50 para Trolox. 

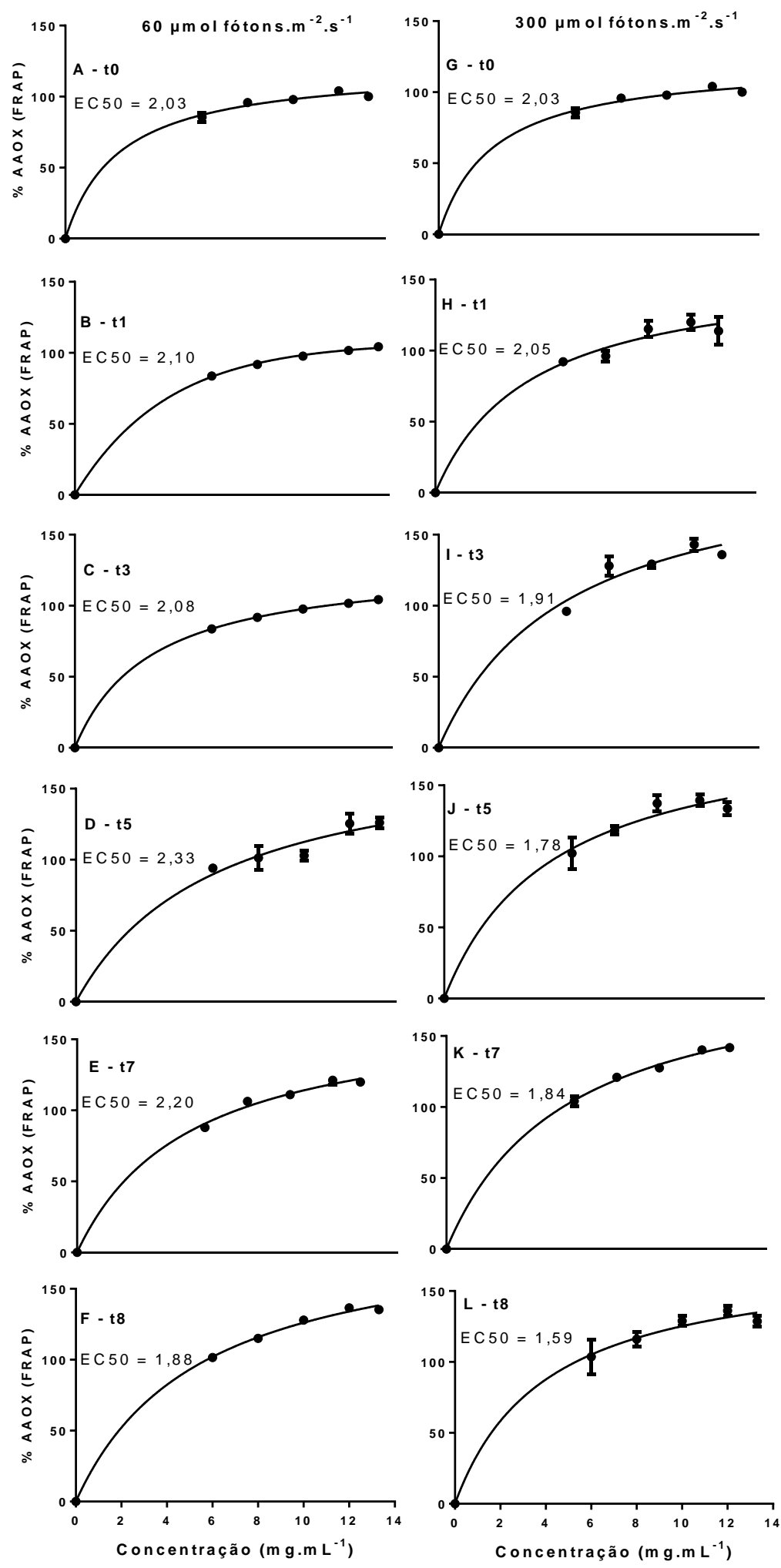

Figura 28. Porcentagem da atividade antioxidante e valores de EC50 para o FRAP em Pterocladiella capillacea ao longo de oito dias de experimento (t0-t8) nas irradiâncias de 60 (A-F) e $300 \mu$ mol fótons. $\mathrm{m}^{-2} \cdot \mathrm{s}^{-1}$ (G-L). 


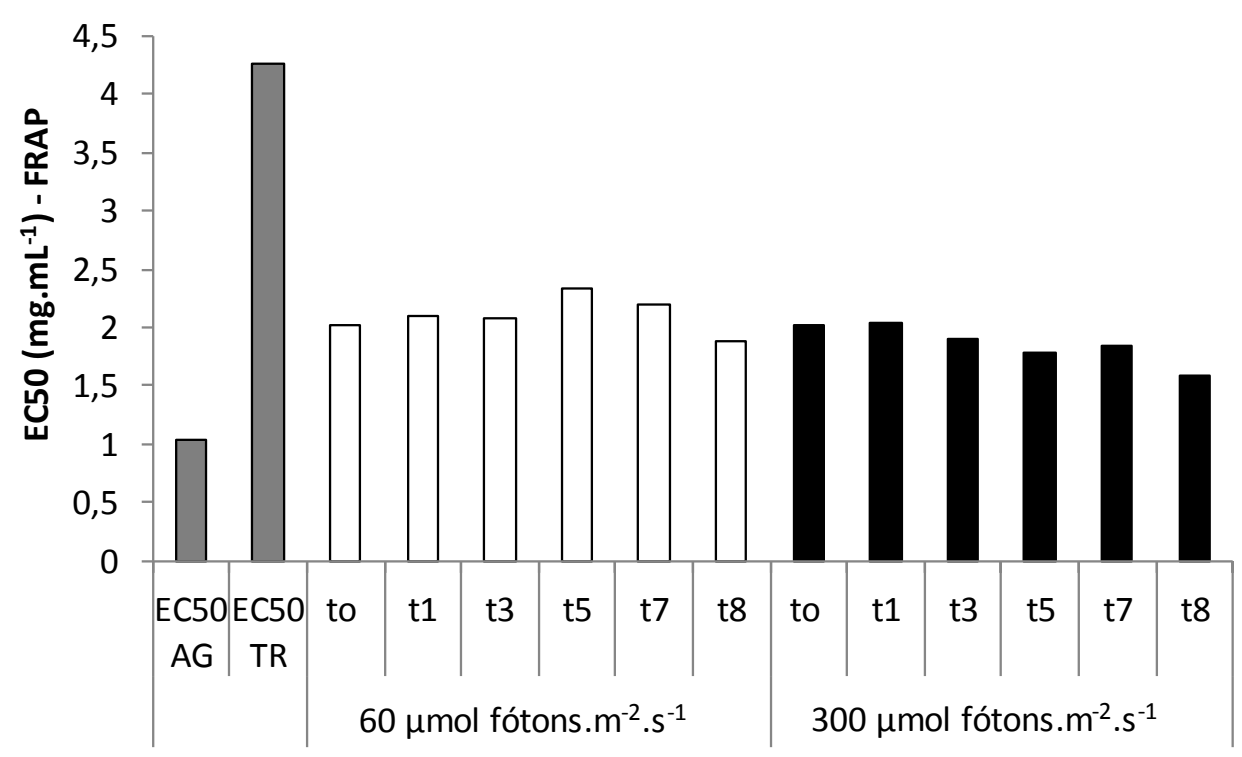

Figura 29. Valores de EC50 para o ensaio do FRAP em Pterocladiella capillacea ao longo de oito dias de experimento nas irradiâncias de 60 e $300 \mu \mathrm{mol}$ fótons.m $\mathrm{m}^{-2} \cdot \mathrm{s}^{-1}$. As barras cinzas (controle) representam o EC50 da curva padrão de ácido gálico e Trolox para o respectivo ensaio.

\subsection{Comparação da atividade antioxidante entre os tratamentos de irradiância e tempo}

\section{DPPH}

A Figura 30A mostra aumento na porcentagem do sequestro do radical DPPH de $44,46 \pm 1,02 \%$ a partir do sétimo dia na irradiância de $60 \mu \mathrm{mol}$ fótons. $\mathrm{m}^{-2} \cdot \mathrm{s}^{-1}$. Em 300 $\mu \mathrm{mol}$ fótons. $\mathrm{m}^{-2} . \mathrm{s}^{-1}$ observou-se que o aumento de irradiância induziu maior atividade antioxidante após 24 h $(43,76 \pm 7,32 \%)$ e no tempo $8(29,83 \pm 10,01 \%)$. Antes de iniciar o experimento, no tempo 0 , o potencial de sequestro de DDPH em P. capillacea foi cerca de 16,00 $\pm 2,65 \%$ para ambas irradiâncias. Comparando os dois tratamentos de luz, a maior variação no potencial antioxidante foi observada no tempo 1 sob $300 \mu \mathrm{mol}$ fótons. $\mathrm{m}^{-2} \cdot \mathrm{s}^{-1}$, onde houve aumento de quase o triplo da atividade registrada no tempo inicial.

A Figura 30F representa o gráfico de atividade relacionado ao equivalente padrão para ácido gálico. As maiores atividades de sequestro de DPPH foram equivalentes a, aproximadamente, 0,011 a 0,109 mg eq. ác.gálico.g ${ }^{-1}$ alga e valores registrados em mg. eq. trolox. $\mathrm{g}^{-1}$ alga foram cinco vezes superior aos resultados obtidos para ácido gálico. 


\section{ABTS}

A Figura 30B mostra que houve aumento na captura do radical livre ABTS na irradiância de $60 \mu \mathrm{mol}$ fótons. $\mathrm{m}^{-2} \cdot \mathrm{s}^{-1}$ a partir do tempo $3(66,87 \% \pm 2,65)$, que se estendeu até o final do experimento no tempo $8(84,02 \% \pm 2,50)$. Em $300 \mu$ mol fótons. $\mathrm{m}^{-2} \cdot \mathrm{s}^{-1}$ houve variação ao longo do tempo com maiores atividades até o terceiro dia. Cabe destacar que na concentração de $12 \mathrm{mg} \cdot \mathrm{mL}^{-1}$ o extrato já mostrava inicialmente no tempo 0 atividade antioxidante aproximadamente de $58 \% \pm 2,10$.

A Figura 30G mostra o gráfico de atividade relacionado ao equivalente padrão para ácido gálico. A faixa de atividade de sequestro de ABTS foi equivalente a, aproximadamente, 0,07 a $0,131 \mathrm{mg}$ eq. ác.gálico.g ${ }^{-1}$ alga e 0,39 a $0,7 \mathrm{mg}$ eq. trolox.g $\mathrm{g}^{-1}$ alga (dados não mostrados).

\section{Quelante de metais}

A Figura 30C mostra pouca variação na atividade quelante de metais ao longo do tempo em cada uma das irradiâncias, assim como ao comparar entre os dois tratamentos de luz. A faixa de atividade para quelantes foi equivalente a, aproximadamente, 0,027 a 0,098 mg eq. ác.gálico.g ${ }^{-1}$ alga (Fig. 30H).

\section{Poder redutor do Folin-Ciocalteu}

A Figura 30D mostra que não houve variação significativa na atividade antioxidante pelo método do Folin-Ciocalteu ao longo do tempo na irradiância de 60 $\mu \mathrm{mol}$ fótons. $\mathrm{m}^{-2} \cdot \mathrm{s}^{-1}$. Em $300 \mu \mathrm{mol}$ fótons. $\mathrm{m}^{-2} \cdot \mathrm{s}^{-1}$ verificou-se que ao longo do tempo houve uma diminuição na porcentagem de potencial antioxidante, sendo significativo a partir do quinto dia. Ao analisar as duas irradiâncias é possível destacar que a atividade antioxidante diminuiu com o aumento de irradiância nos dias 5, 7 e 8 . A faixa de atividade para o poder redutor do Folin-Ciocalteu foi equivalente a, aproximadamente, 1,099 a 3,05 mg eq. ác.gálico.g ${ }^{-1}$ (Fig. 30I). A Tabela 5 sintetiza os valores de equivalente padrão ácido gálico para o conteúdo de fenólicos encontrados em literatura para algumas algas vermelhas. Os valores de P. capillacea em 60 e $300 \mu$ mol fótons.m ${ }^{-}$ ${ }^{2} . \mathrm{s}^{-1}$ representam as maiores atividades obtidas para cada irradiância. 
Tabela 5. Conteúdo de substâncias fenólicas totais (FCT) em equivalente padrão para ácido gálico em macroalgas.

\begin{tabular}{|c|c|c|c|}
\hline Alga & Solvente & FCT (mg GAE g ${ }^{-1}$ alga MS) & Referência \\
\hline \multicolumn{4}{|l|}{ Phaeophyta } \\
\hline Alaria crassifolia & Etanol & $7.21 \pm 0.80$ & Airanthi et al. (2011) \\
\hline Dictyopteris australis & Metanol & $13.37 \pm 0.14$ & Vinayak et al. (2011a) \\
\hline Dictyopteris delicatula & Metanol & $21.34 \pm 0.43$ & Vinayak et al. (2011a) \\
\hline Dictyota dichotoma & Metanol & $35.23 \pm 5.65$ & Matanjun et al. (2008) \\
\hline Eisenia bicyclis & Etanol & $1.87 \pm 0.70$ & Airanthi et al. (2011) \\
\hline Kjellmaniella crassifolia & Etanol & $8.01 \pm 0.78$ & Airanthi et al. (2011) \\
\hline Padina tetrastromatica & Metanol & $25.29 \pm 0.44$ & Vinayk et al. (2011a) \\
\hline Padina spp. & Metanol & $33.11 \pm 3.96$ & Matanjun et al. (2008) \\
\hline Sargassum marginatum & Metanol & $13.19 \pm 0.32$ & Vinayak et al. (2011a) \\
\hline Spatoglossum aspermum & Metanol & $14.13 \pm 0.05$ & Vinayak et al. (2011a) \\
\hline Sargassum variable & Metanol & $14.85 \pm 0.09$ & Vinayak et al. (2011a) \\
\hline Sargassum polycystum & Metanol & $45.16 \pm 3.01$ & Matanjun et al. (2008) \\
\hline Stoechospermum marginatum & Metanol & $20.04 \pm 0.38$ & Vinayak et al. (2011a) \\
\hline \multicolumn{4}{|l|}{ Chlorophyta } \\
\hline Caulerpa lentilifera & Metanol & $42.85 \pm 1.22$ & Matanjun et al. (2008) \\
\hline Caulerpa peltata & Metanol & $38.93 \pm 0.63$ & Vinayak et al. (2011b) \\
\hline Caulerpa taxifolia & Metanol & $24.09 \pm 0.65$ & Vinayak et al. (2011b) \\
\hline Caulerpa racemosa & Metanol & $23.12 \pm 0.49$ & Vinayak et al. (2011b) \\
\hline Caulerpa racemosa & Metanol & $40.36 \pm 1.05$ & Matanjun et al. (2008) \\
\hline Chlorodesmis fastigiata & Metanol & $7.32 \pm 0.35$ & Vinayak et al. (2011b) \\
\hline Codium elongatum & Metanol & $7.41 \pm 0.28$ & Vinayak et al. (2011b) \\
\hline \multicolumn{4}{|l|}{ Rhodophyta } \\
\hline Gracilaria birdie & Etanol & $1.13 \pm 0.03$ & Souza et al. (2011) \\
\hline Gracilaria birdie & Metanol & $1.06 \pm 0.07$ & Souza et al. (2011) \\
\hline Gracilaria cornea & Etanol & $0.88 \pm 0.03$ & Souza et al. (2011) \\
\hline Gracilaria cornea & Metanol & $0.89 \pm 0.07$ & Souza et al. (2011) \\
\hline Eucheuma cottonii & Metanol & $22.50 \pm 2.78$ & Matanjun et al. (2008) \\
\hline Eucheuma spinosa & Metanol & $15.82 \pm 1.24$ & Matanjun et al. (2008) \\
\hline Halymenia durvillae & Metanol & $18.90 \pm 1.03$ & Matanjun et al. (2008) \\
\hline Amansia multifida & Etanol & $45.40 \pm 2.99$ & Alencar et al. (2014) \\
\hline Meristiella echinocarpa & Etanol & $28.46 \pm 2.79$ & Alencar et al. (2014) \\
\hline Pterocladiella capillacea 60 & Metanol & $6,06 \pm 0,37$ & Presente estudo \\
\hline Pterocladiella capillacea 300 & Metanol & $5,34 \pm 0,22$ & Presente estudo \\
\hline
\end{tabular}




\section{Potencial de redução do Ferro}

A Figura 30E mostra que houve aumento no poder de redução do ferro no tempo 8 para a irradiância de $60 \mu \mathrm{mol}$ fótons. $\mathrm{m}^{-2} \cdot \mathrm{s}^{-1}$. Em $300 \mu \mathrm{mol}$ fótons. $\mathrm{m}^{-2} \cdot \mathrm{s}^{-1}$ observou-se maior atividade antioxidante no tempo 3 , de $39,44 \% \pm 4,53$ permanecendo significativamente alto até o fim do experimento. Ao comparar as duas irradiâncias é possível destacar que em $300 \mu \mathrm{mol}$ fótons. $\mathrm{m}^{-2} \cdot \mathrm{s}^{-1}$ houve aumento mais rápido da atividade antioxidante, a partir de terceiro dia, quando comparado a irradiância de 60 $\mu$ mol fótons. $\mathrm{m}^{-2} \cdot \mathrm{s}^{-1}$ que obteve aumento apenas no oitavo dia.

A faixa de atividade para o método do FRAP foi equivalente a, aproximadamente, 0,08 a 0,12 mg eq. ác.gálico.g ${ }^{-1}$ alga e 0,20 a 0,29 mg eq. ác.trolox.g ${ }^{-}$ ${ }^{1}$ alga (dados não apresentados). 

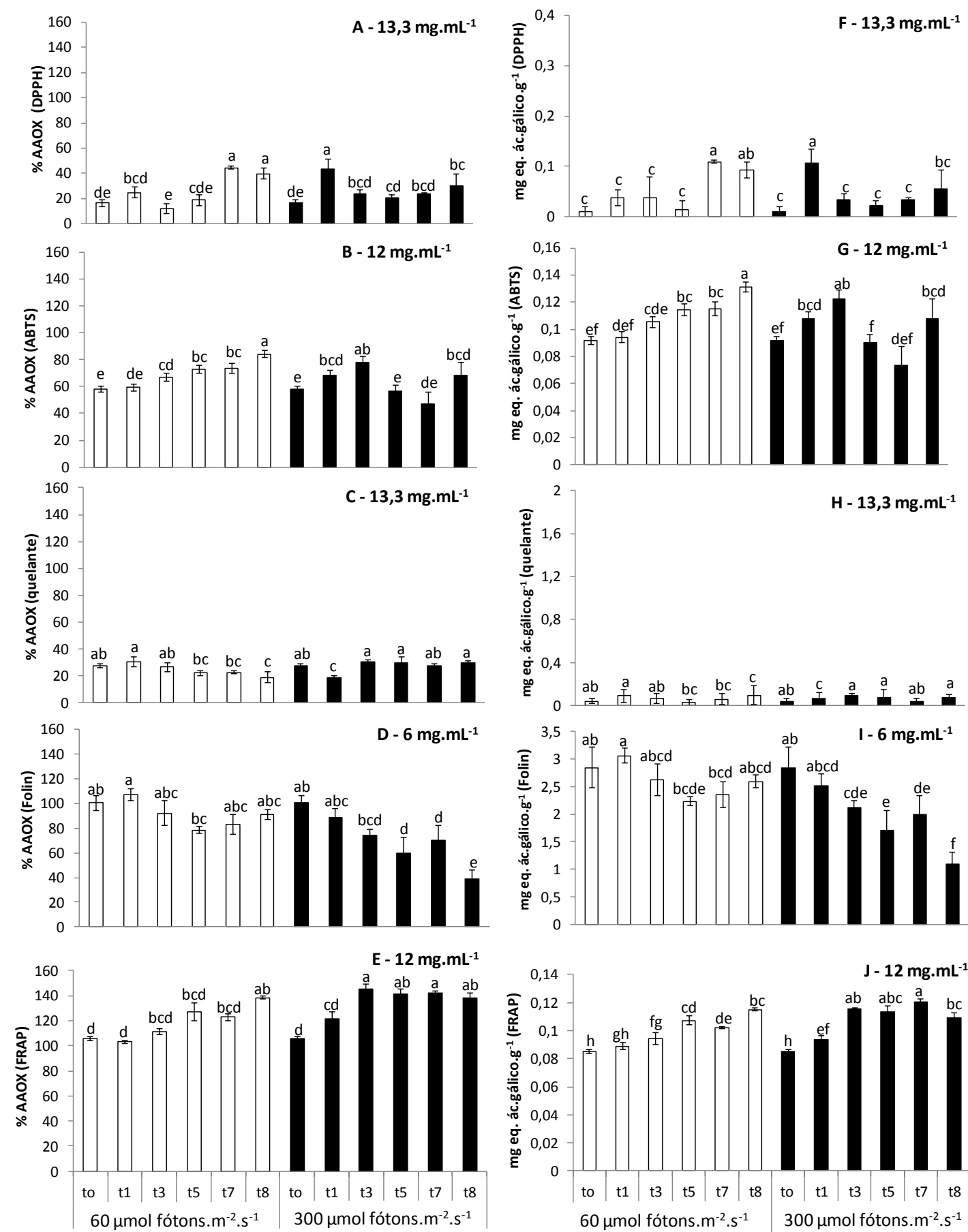

Figura 30. Porcentagem de atividade antioxidante e equivalente padrão ácido gálico para (A e F) sequestro do radical DPPH, (B e G) captura do radical ABTS, (C e H) atividade quelante de metais, (D e I) poder redutor do Folin-Ciocalteu, (E e J) potencial de refução do ferro (FRAP) em Pterocladiella capillacea ao longo de oito dias de experimento nas irradiâncias de 60 e $300 \mu \mathrm{mol}$ fótons. $\mathrm{m}^{-2} \cdot \mathrm{s}^{-1}$. Os valores representam a média \pm desvio padrão $(n=5)$. Letras distintas indicam diferença significativa $(\mathrm{p}<$ $0,05)$ após a ANOVA bifatorial e teste post-hoc de Newman-Keuls. 


\subsection{Potencial antioxidante de extratos metanólicos e tamponados da extração de pigmentos}

O potencial antioxidante dos extratos metanólicos e tamponados de $P$. capillacea provenientes das extrações de pigmentos também foram estudados (ver detalhes no item 2 de Material e métodos). Os extratos metanólicos não apresentaram atividade antioxidante em nenhum dos ensaios testado (dados não mostrados).

\section{Sequestro do radical DPPH}

De forma geral, para o ensaio do sequestro do radical DPPH, foi observado aumento do percentual de atividade antioxidante ao longo do tempo para cada uma das irradiâncias testadas (Fig. 31A). Em $60 \mu \mathrm{mol}$ fótons. $\mathrm{m}^{-2} \cdot \mathrm{s}^{-1} \mathrm{o}$ aumento foi registrado no tempo $8(15,8 \% \pm 0,6)$. Em $300 \mu \mathrm{mol}$ fótons. $\mathrm{m}^{-2} \cdot \mathrm{s}^{-1}$ houve aumento após 7 dias de experimento $(16,0 \pm 1,7 \%)$. Ao comparar as duas irradiâncias observou-se que o estímulo de atividade antioxidante foi mais rápido em $300 \mu \mathrm{mol}$ fótons. $\mathrm{m}^{-2} \cdot \mathrm{s}^{-1}$. Cabe destacar que antes de iniciar o experimento, $P$. capillacea já possuía atividade basal de sequestro do radical DPPH de $8,8 \pm 1,0 \%$.

As maiores atividades de sequestro de DPPH foram equivalentes a, aproximadamente, 0,029 a 0,086 mg eq. ác.gálico.g ${ }^{-1}$ alga e 0,07 (Fig. 31F) a 0,33 mg. eq. trolox.g ${ }^{-1}$ alga (dados não mostrados).

\section{Sequestro do radical ABTS}

Para o sequestro do radical ABTS, a porcentagem de atividade antioxidante diminuiu ao longo do tempo sob irradiancia de $60 \mu \mathrm{mol}$ fótons. $\mathrm{m}^{-2} \cdot \mathrm{s}^{-1}$, o mesmo padrão foi observado para irradiância de $300 \mu \mathrm{mol}$ fótons.m ${ }^{-2} \cdot \mathrm{s}^{-1}$ (Fig. 31B). Ambas irradiâncias apresentaram a mesma tendência, tendo os menores valores registrados nos tempos 5 e 7. No tempo inicial 0, o ABTS já mostrava uma atividade antioxidante de $32,7 \% \pm 1,3$.

As maiores atividades de sequestro do radical ABTS foram equivalentes a, aproximadamente, 0,05 a 0,12 mg eq. ác.gálico.g ${ }^{-1}$ alga (Fig. 31G) e 0,45 a 0,82 mg. eq. trolox. $\mathrm{g}^{-1}$ alga (dados não mostrados). 


\section{Atividade quelante de metais}

Para a atividade quelante de metais, a porcentagem de atividade antioxidante não variou ao longo do tempo sob irradiancia de $60 \mu \mathrm{mol}$ fótons. $\mathrm{m}^{-2} \cdot \mathrm{s}^{-1}$ (Fig. $31 \mathrm{C}$ ). Em 300 $\mu$ mol fótons. $\mathrm{m}^{-2} \cdot \mathrm{s}^{-1}$ houve aumento $24 \mathrm{~h}$ após o estímulo de luz, em $\mathrm{t} 1(82,3 \% \pm 6,2)$. No entanto, tal aumento foi apenas transitório, os tempos seguintes foram iguais aos iniciais. Ao comparar as irradiâncias, observou-se que o aumento de luz induziu a atividade quelante de metais após $24 \mathrm{~h}$. No tempo inicial, t0 a atividade antioxidante de $45,6 \% \pm 5,3$.

As maiores atividades foram equivalentes a, aproximadamente 1,8 a 2,99 $\mathrm{mg}$ eq. ác.gálico.g ${ }^{-1}$ alga (Fig. 31H).

\section{Método do Folin-Ciocalteu}

Para o poder redutor do reagente Folin-Ciocalteu, a porcentagem de atividade antioxidante aumentou ao longo do tempo sob irradiancia de $60 \mu \mathrm{mol}$ fótons. $\mathrm{m}^{-2} \cdot \mathrm{s}^{-1}$ atingindo no tempo 8 uma atividade 2,6 vezes superior ao tempo 0 (inicial) (Fig. 31D). Nao houve variação na atividade antioxidante ao longo do tempo sob $300 \mu$ mol fótons. $\mathrm{m}^{-2} \cdot \mathrm{s}^{-1}$. Ao analisar as duas irradiâncias, observou-se que o aumento de luz não induziu a atividade antioxidante para o poder redutor do reagente Folin-Ciocalteu.

As maiores atividades para o Folin foram equivalentes a, aproximadamente, 0,24 a $0,79 \mathrm{mg}$ eq. ác.gálico. $\mathrm{g}^{-1}$ alga (Fig. 31I) e 1,2 a 3,8 mg. eq. trolox.g ${ }^{-1}$ alga (dados não mostrados).

\section{Potencial de redução do Ferro (FRAP)}

Para o poder de redução do ferro, a porcentagem de atividade antioxidante reduziu ao longo do tempo sob irradiancia de $60 \mu \mathrm{mol}$ fótons. $\mathrm{m}^{-2} \cdot \mathrm{s}^{-1}$. A mesma tendência foi observada em $300 \mu \mathrm{mol}$ fótons. $\mathrm{m}^{-2} \cdot \mathrm{s}^{-1}$ (Fig. 31E). Ao analisar as duas irradiâncias, observou-se que o aumento de luz não induziu a atividade antioxidante para o ensaio do FRAP, no entanto a redução da atividade antioxidante só foi verificada

a partir do tempo 3, ao passo que sob irradiância de $60 \mu \mathrm{mol}$ fótons. $\mathrm{m}^{-2} \cdot \mathrm{s}^{-1}$ a porcentagem de atividade antioxidante reduziu a partir do tempo 1. 
As maiores atividades para o FRAP foram equivalentes a, aproximadamente, 0,05 a $0,11 \mathrm{mg}$ eq. ác.gálico.g ${ }^{-1}$ alga (Fig. 31J) e 0,12 a 0,28 mg. eq. trolox.g $\mathrm{g}^{-1}$ alga (dados não mostrados).
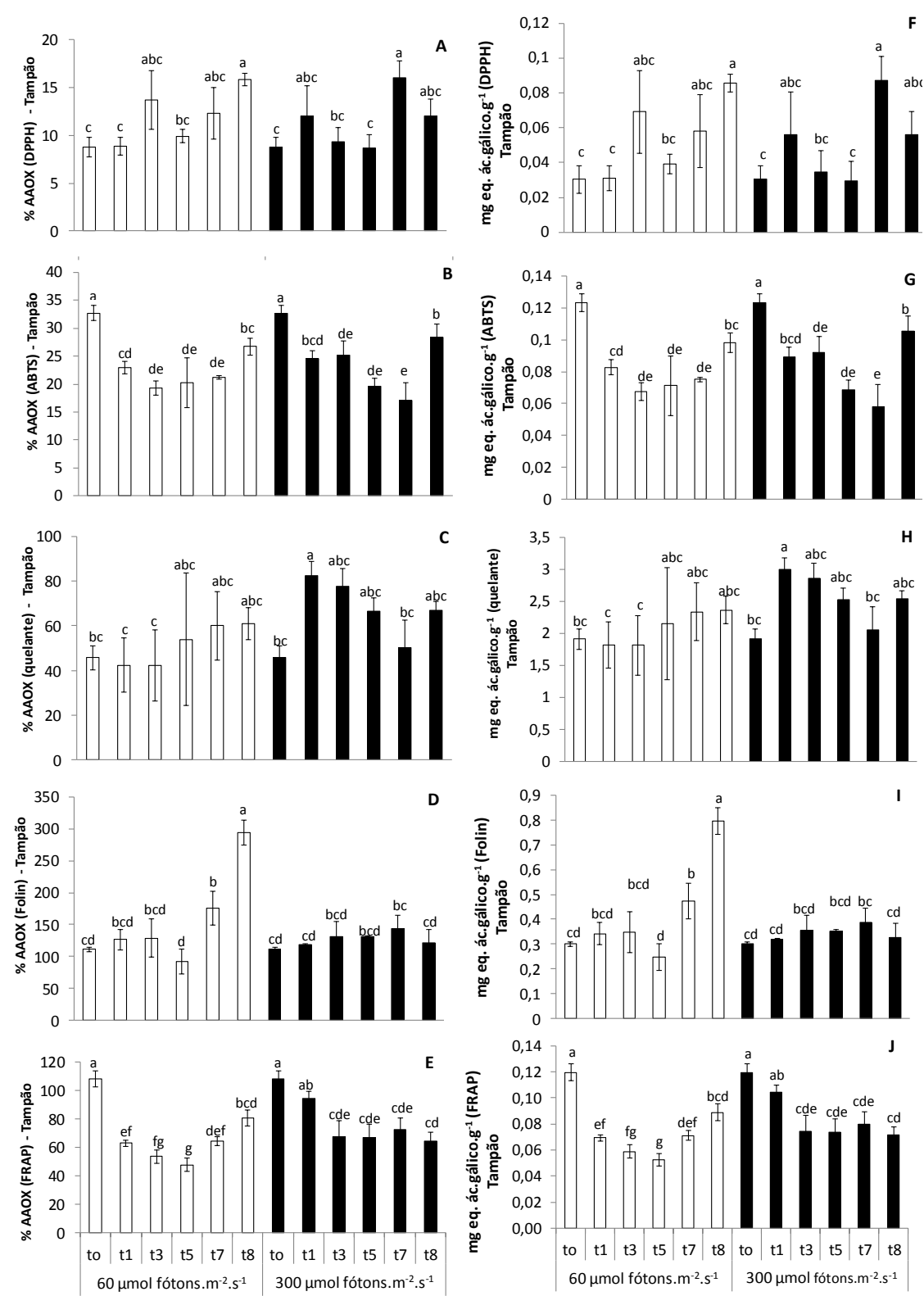

Figura 31. Porcentagem de atividade antioxidante e equivalente padrão ácido gálico para os extratos tamponados de pigmentos. (A e F) sequestro do radical DPPH, (B e G) captura do radical ABTS, $(\mathrm{C}$ e $\mathrm{H})$ atividade quelante de metais, (D e I) poder redutor do Folin-Ciocalteu, (E e J) potencial de redução do ferro (FRAP) em Pterocladiella capillacea ao longo de oito dias de experimento nas irradiâncias de 60 e $300 \mu$ mol fótons. $\mathrm{m}^{-2} \cdot \mathrm{s}^{-1}$. Os valores representam a média \pm desvio padrão $(\mathrm{n}=5)$. Letras distintas indicam diferença significativa $(\mathrm{p}<0,05)$ após a ANOVA bifatorial e teste post-hoc de Newman-Keuls. 
A análise de componentes principais para as variáveis do potencial antioxidante de P.capillacea nos permite explicar $78,92 \%$ das tendências dos resultados deste capítulo. (Fig. 32). A PCA formada pelos componentes 1 e 2 são condizentes com as correlações de Pearson (ver Anexo V, Fig. AV 2 e Tabela AV 2).

Os ensaios antioxidantes influenciaram os tratamentos para os quais seus vetores estão apontados. DPPH e ABTS (t5 e t7 de $300 \mu \mathrm{mol}$ fótons. $\left.\mathrm{m}^{-2} \cdot \mathrm{s}^{-1}\right)$, quelantes $(\mathrm{t} 5,7,8$ de $60 \mu \mathrm{mol}$ fótons. $\mathrm{m}^{-2} . \mathrm{s}^{-1}$ e $\mathrm{t} 1$ de $300 \mu \mathrm{mol}$ fótons. $\mathrm{m}^{-2} \cdot \mathrm{s}^{-1}$ ), Folin (t3 e t8 de $300 \mu \mathrm{mol}$ fótons. $\mathrm{m}^{-2} \cdot \mathrm{s}^{-1}$ ) e FRAP (tempo inicial 0 e $\mathrm{t} 1$, $\mathrm{t} 3$ de $60 \mu \mathrm{mol}$ fótons. $\mathrm{m}^{-2} \cdot \mathrm{s}^{-1}$ ). Esses métodos causaram a maior variação entre todo o conjunto de dados para os respectivos tratamentos.

Existiu uma relação mais próxima e homogênea entre os tempos de $300 \mu \mathrm{mol}$ fótons. $\mathrm{m}^{-2} \cdot \mathrm{s}^{-1} \mathrm{e}$ duas relações podem ser distinguidas entre os tempos em $60 \mu \mathrm{mol}$ fótons. $\mathrm{m}^{-2} \cdot \mathrm{s}^{-1}$.

Em $60 \mu \mathrm{mol}$ fótons. $\mathrm{m}^{-2} . \mathrm{s}^{-1}$, os tempos iniciais se agruparam (t0-t3), a partir do quinto dia houve distanciamento dos menores. Foi possível definir três principais grupos: (a) tratamentos iniciais de 60 e $300 \mu \mathrm{mol}$ fótons. $\mathrm{m}^{-2} \cdot \mathrm{s}^{-1}$ (tempo 0 ) e tempos 1 e 3 de $60 \mu \mathrm{mol}$ fótons. $\mathrm{m}^{-2} \cdot \mathrm{s}^{-1}$; (b) tempos finais $5,7,8 \mathrm{de} 60 \mu \mathrm{mol}$ fótons. $\mathrm{m}^{-2} \cdot \mathrm{s}^{-1}$ e 1 de 300 $\mu$ mol fótons.m ${ }^{-2} \cdot \mathrm{s}^{-1}$; (c) relação dos tempos $3,5,7$ e 8 de $300 \mu$ mol fótons. $\mathrm{m}^{-2} \cdot \mathrm{s}^{-1}$. Esses três grandes grupos também foram evidenciados na dendograma de Cluster (Fig. 33).

O gráfico biplot da PCA (Fig. 32) mostra que a variação nos tratamentos de 300 $\mu$ mol fótons. $\mathrm{m}^{-2} \cdot \mathrm{s}^{-1}$ foi melhor explicada, principalmente, pelos parâmetros: DPPH, ABTS e Folin. Para os tratamentos de $60 \mu \mathrm{mol}$ fótons. $\mathrm{m}^{-2} \cdot \mathrm{s}^{-1}$, as métricas que explicaram a maior variação desse conjunto foram: quelante e FRAP. Os vetores mostram que as variações positivas e negativas dentre os dados foram similares para os tratamentos de irradiância, não sendo possível definir um padrão (Fig. 32).

O cluster de agrupamento considerando as métricas obtidas para o potencial antioxidante de P. capillacea é mostrado na Figura 34. Dentre os parâmetros testados, quelantes e Folin foram as variáveis que mais divergiram no dendograma, o qual mantiveram-se distintos dos demais grupos formados, pelo fato dessas variáveis possuírem pouca semelhança em relação às outras. 


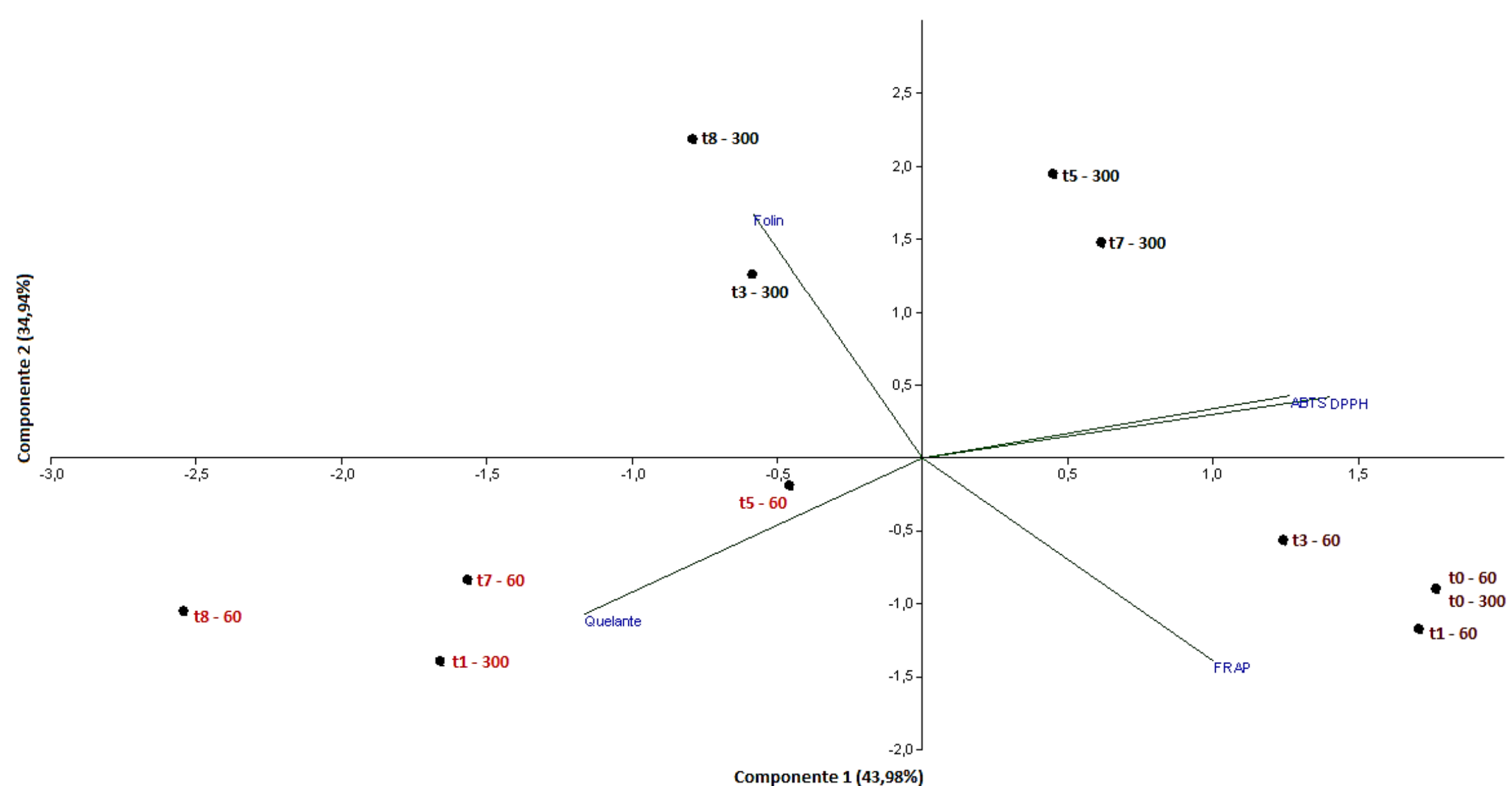

Figura 32. Ordenação biplot dos componentes 1 e 2 de $P$. capillacea durante o periodo experimental (t0, t1, t3, t5, t7 e t8) em função das variáveis métricas de DPPH, ABTS, Quelante, Folin e FRAP para irradiâncias de 60 e $300 \mu$ mol fótons.m ${ }^{-2} . \mathrm{s}^{-1}$. As cores vermelha, marrom e preta indicadas em cada tratamento representam os três agrupamentos. 


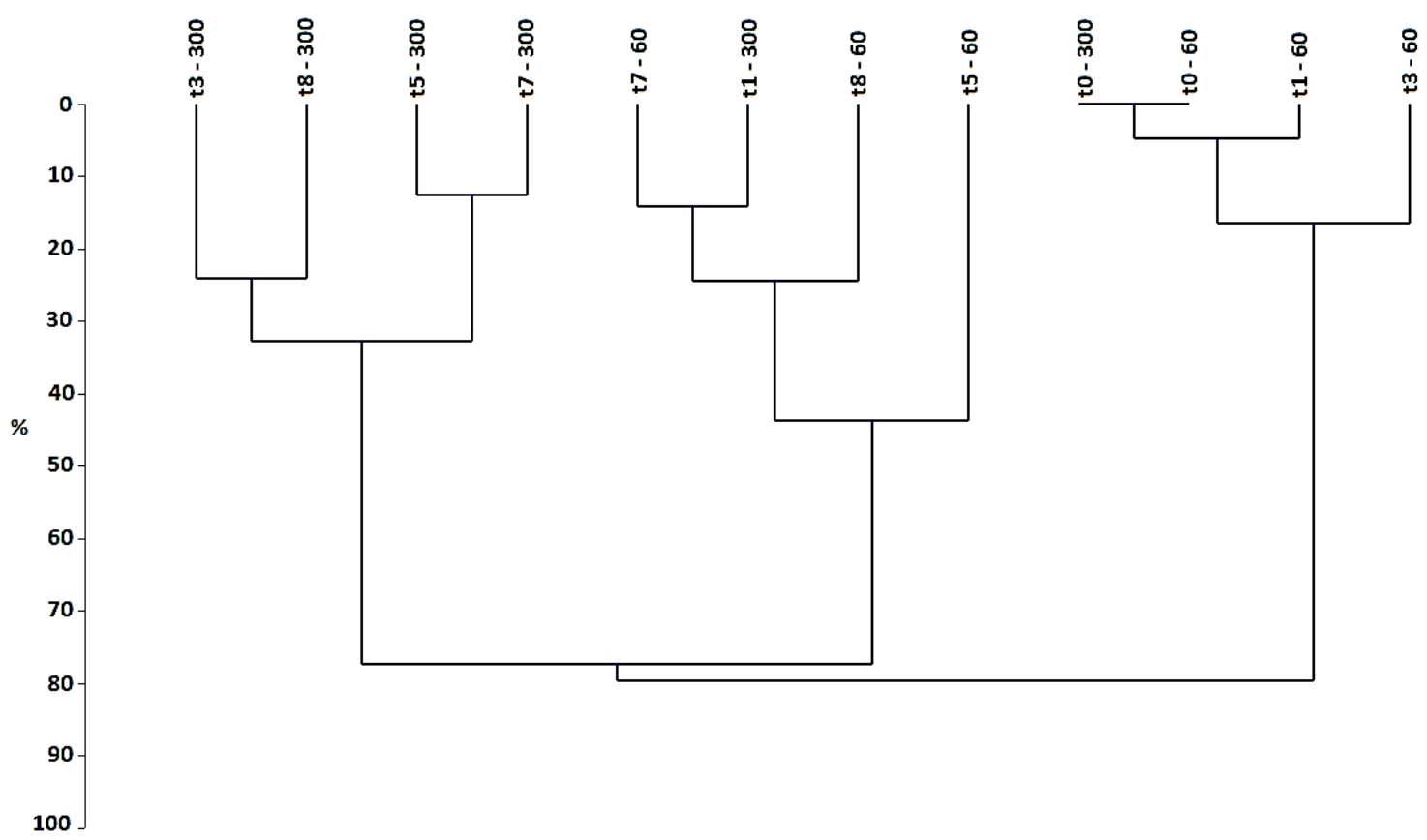

Figura 33. Dendrograma obtido da análise de agrupamento hierárquico utilizando os tratamentos de Pterocladiella capillacea ao longo do tempo (t0, t1, t3, t5, t7 e t8) para irradiâncias de 60 e $300 \mu \mathrm{mol}$ fótons. $\mathrm{m}^{-2} \cdot \mathrm{s}^{-1}$.

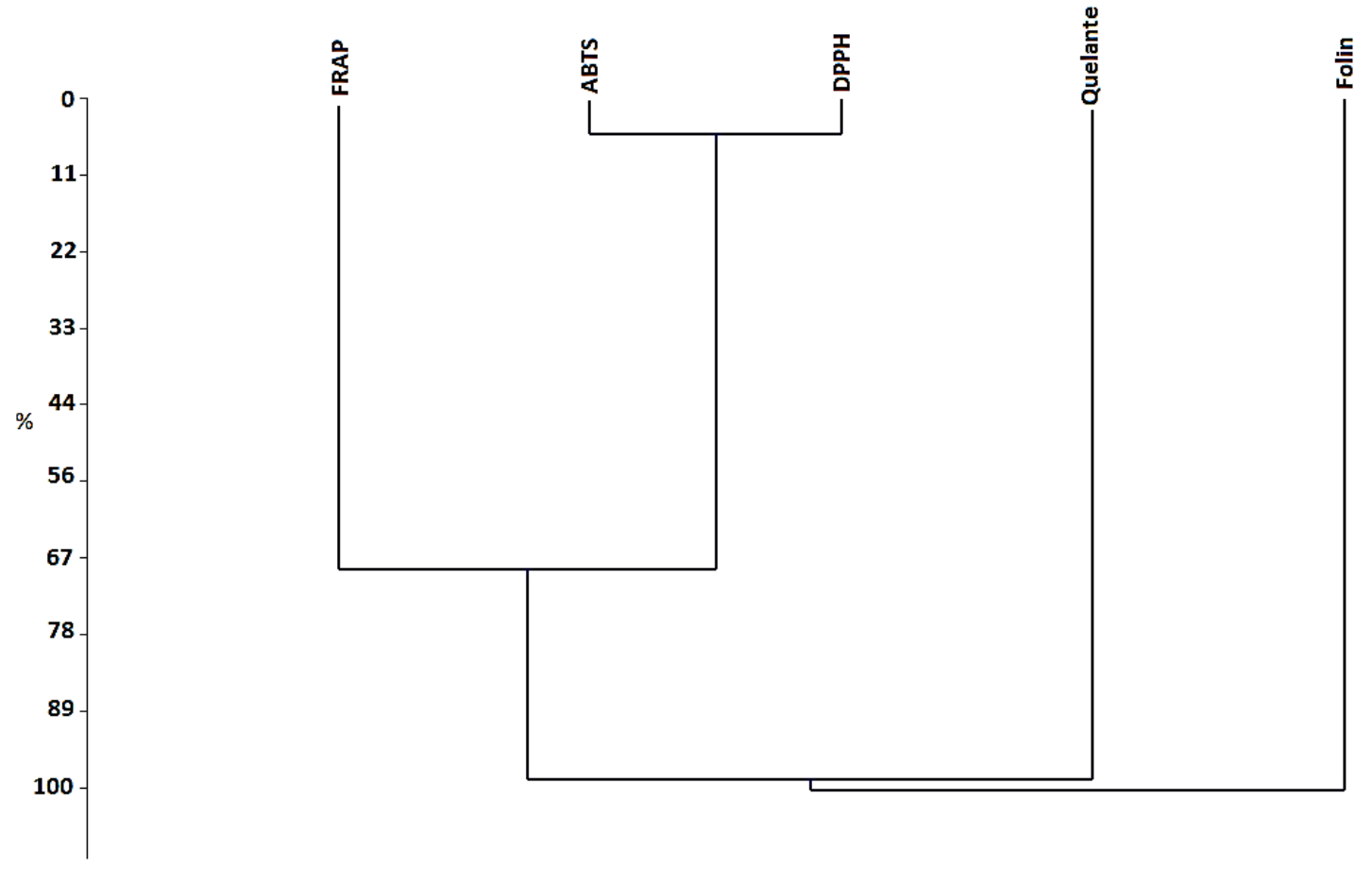

Figura 34. Dendrograma obtido da análise de agrupamento hierárquico utilizando as métricas resultantes de Pterocladiella capillacea avaliadas nos diferentes tempos e irradiâncias. 


\section{Discussão}

Os parâmetros aqui analisados auxiliam a elucidação de alguns mecanismos de tolerância ativados frente ao aumento de luz em $P$. capillacea.

Os resultados do presente estudo indicam que existe variação na atividade antioxidante ao longo do período experimental para cada uma das irradiâncias estudadas. Foi possível verificar que o aumento de luz pode induzir maior atividade antioxidante. Esta correlação positiva foi evidenciada para os métodos DPPH (maior atividade no primeiro dia), ABTS (maior atividade até o terceiro dia) e FRAP (maior atividade a partir do terceiro dia). Por outro lado, o estímulo de $300 \mu \mathrm{mol}$ fótons. $\mathrm{m}^{-2} \cdot \mathrm{s}^{-1}$ não induziu o aumento de atividade antioxidante para os ensaios da atividade quelante de metais e poder redutor do reagente Folin-Ciocalteu.

Os antioxidantes pelos quais são detectados pelo método do DPPH e atividade quelantes de metais não foram significativos nas amostras e apresentaram baixa atividade antioxidante. Dessa forma, os extratos metanólicos de $13,3 \mathrm{mg} \cdot \mathrm{mL}^{-1}$ de $P$. capillacea não possuem boa atividade para estes ensaios.

Do ponto de vista do potencial, o ensaio do radical ABTS mostrou uma atividade razoável, pois esteve acima de 50\% de atividade antioxidante. Entretanto, apresentou valores de EC50 muito acima dos padrões comerciais ácido gálico e Trolox. Dessa forma, o ABTS apresenta alta atividade quando observada a porcentagem de atividade antioxidante, mas quando comparado às substâncias referências em EC50 é quatro ou cinco vezes superior aos padrões testados. Ainda assim, é importante ressaltar que o extrato metanólico de $P$. capillacea na concentração de $12 \mathrm{mg} \cdot \mathrm{mL}^{-1}$ não deixa de ser uma potencialidade, pois evidenciou-se uma porcentagem acima de 50\% de atividade.

O ensaio do Folin-Ciocalteu apresentou boa atividade antioxidante que diminuiu com o aumento de luz, provavelmente devido a uma degradação de substâncias fenólicas. Dessa forma, os antioxidantes detectados por Folin não reagiram bem à maior intensidade luminosa. Se considerarmos que o ensaio do Folin detecta fenóis, tais compostos são reduzidos em suas concentrações quando expostos a maior quantidade de luz, em contra partida outros antioxidantes determinados por FRAP são estimulados pelo aumento da intensidade luminosa.

O método do FRAP apresentou boa atividade e os antioxidantes detectados neste ensaio foram induzidos por luz. Com o objetivo de aumentar a eficiência de antioxidantes 
detectados pelo FRAP, em uma condição de cultivo com mais luz, é possível colher o material antes (3 dias) do que em um cultivo com menos luz ( 8 dias).

$\mathrm{O}$ aumento de luz demanda mais fotossíntese, estimula o metabolismo e consequentemente há menos nutrientes. Talvez o esgotamento de nutrientes após o terceiro dia, fez com que a $P$. capillacea não continuasse a produção de antioxidantes de forma linear até o fim do experimento. Entretanto, possivelmente a adição de nutriente não seja um fator de estresse, mas sim um mecanismo para indução de defesa. Provavelmente no tempo 5, $P$. capillacea, não conseguiu produzir antioxidantes como defesa ao estresse oxidativo, pois estava em uma condição limitante em termos de nitrogênio. Acredita-se que algas em melhores condições de nitrogênio, possuam condições mais favoráveis para ativar mecanismos de defesa.

Em questão dos métodos que detectam oxidação por íons ferro, o ensaio que mostrou maior sensibilidade foi o FRAP quando comparado ao quelante de metais, pois apresentou variações significativas. No ensaio quelante, a detecção foi muito baixa. A atividade quelante de metal de um composto antioxidante impede a formação de espécies reativas de oxigênio e, consequentemente o dano oxidativo (Kumar et al., 2008). Rupérez et al. (2002) testaram a atividade antioxidante dos polissacarídeos de Fucus vesiculosus Linnaeus frente à redução de íons férricos, a presença de fucose demonstrou maior potencial antioxidante, reduzindo o ensaio do poder antioxidante férrico. A fração polissacaridea da alga vermelha Gracilaria caudata J. Agardh apresentou uma excelente capacidade quelante de íons de ferro (Costa et al., 2008).

De forma geral, de acordo com os três ensaios que deram acima de 40\% (ABTS, Folin e FRAP), pode-se inferir que $P$. capillacea é uma alga com bom potencial antioxidante, que pode ser melhor explorado como bioproduto funcional. Em relação, ao efeito biológico da luz, aparentemente há uma indução em antioxidantes detectados pelo método do FRAP e há uma inibição em antioxidantes detectados pelo Folin. Quanto à atividade antioxidante detectada pelo ensaio de ABTS sob efeito da luz, não houve uma tendência clara, ocorre oscilação, aumentando e diminuindo ao longo do tempo. Para o sequestro do radical DPPH e atividade quelante de metais, houve poucas variações entre os tratamentos e ao longo do tempo.

Devido à alta atividade, os ensaios ABTS, FRAP e Folin-Ciocalteu mostraram-se apropriados para avaliar a atividade antioxidante da espécie em estudo. O ensaio do DPPH e 
atividade quelantes de metais mostram-se inadequados nas concentrações testadas para $P$. capillacea.

No presente estudo optou-se por avaliar a atividade antioxidante total. No entanto, uma vez que $P$. capillacea responde de forma transiente ao longo do tempo é possível que no segundo ou terceiro dia de experimento outros mecanismos antioxidantes possam atuar, como por exemplo, as enzimas catalase e ascorbato peroxidase que não foram medidas neste trabalho.

Os ensaios para DPPH, ABTS, quelante de metais e FRAP demonstram atividade antioxidante em 13,3 mg.mL $\mathrm{m}^{-1}$, no entanto os resultados mostram que concentrações acima deste valor devem ser testadas. Ganesan et al. (2007) avaliaram a atividade antioxidante in vitro de três macroalgas vermelhas, os autores reportaram que a atividade antioxidante de todas as espécies eram dose-dependentes e aumentavam de acordo com o aumento da concentração de extrato bruto. Dessa forma, recomenda-se testar concentrações maiores que 13,3 mg.mL ${ }^{-1}$ para futuros estudos com P. capillacea. Para o ensaio do Folin-Ciocalteu foi observada uma boa atividade antioxidante na menor concentração testada $6 \mathrm{mg} \cdot \mathrm{mL}^{-1}$, sugerese testar concentrações inferiores para este ensaio.

Os extratos metanólicos de pigmentos não reagiram bem para os ensaios antioxidantes testados (dados não apresentados), tais resultados já eram esperados e corroboram com os dados do presente estudo que indicam que as concentrações do extrato metanólico para atividade antioxidante em $P$. capillacea devem ser acima de $13,3 \mathrm{mg} \cdot \mathrm{mL}^{-1}$, exceto para o ensaio do poder redutor do Folin-Ciocalteu. Sendo assim, para se utilizar um extrato metanólico para ensaios antioxidantes com $P$. capillacea será necessário partir da concentração mínima de $15 \mathrm{mg} \cdot \mathrm{mL}^{-1}$ de extrato bruto. Os extratos aquosos de pigmentos tiveram reação com todos os antioxidantes testados, tais resultados indicam a existência de compostos que possuam um bom potencial antioxidante que é facilmente extraído com água/tampão.

A alta atividade do extrato aquoso pode estar atribuída aos polissacarídeos, pigmentos, substâncias fenólicas e micosporinas, todos estes hidrosolúveis e que podem estar presentes nesse extrato. Em questão de aplicação vale a pena fazer extratos metanólicos e aquosos, pois dessa forma é possível juntar potencialidades de extratos específicos. Foi possível verificar que existem muitos compostos com atividade quelante metais nos extratos aquosos que não 
são extraídos no metanólicos. Juntar o que se consegue extrair em extratos aquosos e metanólicos seria muito interessante.

Tariq et al. (2011) avaliaram a eficiência da atividade antioxidante dos extratos aquosos e etanólicos de 15 macroalgas, os autores observaram que os extratos aquosos mostraram-se mais promissores comparados aos etanólicos.

Os compostos fenólicos são geralmente mais solúveis em solvente orgânico polar do que em água. Outros compostos, tais como polissacáridos, proteínas e ácido orgânico, são simultaneamente extraídos quando utiliza-se água como solvente único (Chirinos et al., 2007). As substâncias fenólicas não são encontradas majoritariamente em algas vermelhas. Wang et al. (2009) observaram diferenças significativas no teor de fenólicos totais entre diferentes espécies de algas (pardas, vermelhas e verdes) e as algas pardas foram as que apresentaram quantidades mais elevadas de polifenóis do que algas vermelhas e verdes.

Ganesan et al. (2007) observaram que os extratos que possuíam altos níveis de polifenóis não eram potentes na eliminação de radicais DPPH, o que sugere que os polifenóis algais não eram os principais componentes responsáveis pelas propriedades anti-radicalares dos extratos. A mudança na polaridade do extrato altera a sua eficácia para extrair um grupo específico de compostos antioxidantes e influencia as propriedades antioxidantes dos extratos. Outras classes de compostos antioxidantes tais como fucoxantina e esteróis poderiam ser parcialmente e simultaneamente extraídos (Chernande et al., 2014) e, portanto, podem ter contribuído para as atividades globais encontradas nos extratos tamponados do presente estudo.

Kiran \& Murugesan (2014) avaliaram a atividade antioxidante de Colpomenia sinuosa (Mertens ex Roth) Derbès \& Solier e Halymenia poryphyroides C.Agardh, as autoras reportaram boas atividades antioxidantes para duas espécies mediante os ensaios do DPPH (porcentagens de inibição acima de 70\%) e ABTS (porcentagens de inibição acima de 50\%). No presente estudo, P. capillacea apresentou repostas semelhantes para o ensaio do ABTS. No entanto, o ensaio do ABTS possui algumas limitações, tais como a capacidade de uma amostra reagir com radical ABTS, em vez de inibir o processo oxidativo, além da reação lenta de muitos compostos fenólicos (Roginsky \& Lissi, 2005). Dessa forma torna-se necessária a utilização de outros ensaios antioxidantes complementares para avaliar a real resposta antioxidante de um extrato. 
Pterocladiella capillacea apresentou baixa atividade antioxidante para o ensaio do DPPH e, portanto, nas condições testadas, não seria considerada um bom antioxidante comparado aos padrões comerciais de ácido gálico e Trolox. Zubia \& Robledo (2007) analisaram a capacidade antioxidantes em 48 extratos de macroalgas vermelhas, pardas e verdes no litoral do México. Os autores observaram que a rodófita Chondria baileyana (Montagne) Harvey, a feofícea Lobophora variegata (J.V. Lamouroux) Womersley ex E.C. Oliveira e a clorófita Avrainvillea longicaulis (Kützing) G. Murray \& Boodle obtiveram destaque, sendo as mais ativas através do método de inibição do radical DPPH, tendo suas capacidades antioxidantes equiparadas a importantes antioxidantes comerciais como ácido ascórbico e BHT (butil hidroxi tolueno).

De acordo com a figura modificada de Zubia \& Robledo (2007) mostrada nos resultados, é possível inferir que os valores de EC50 para o ensaio do DPPH em $P$. capillacea seria estimado a partir de concentrações acima de $13,3 \mathrm{mg} \cdot \mathrm{mL}^{-1}$, no entanto com os valores obtidos com o EC20 e EC40 é possível observar que o aumento de luz altera a atividade antioxidante em P. capillacea.

Pterocladiella capillacea apresenta resultados similares às espécies do gênero Gracilaria Greville, Zubia \& Robledo (2007) relataram baixas atividades antioxidantes para este gênero (28\%). O extrato metanólico de Gracilaria verrucosa (Hudson) Papenfuss apresentou 40\% de inibiação do radical DPPH no estudo de Yan et al. (1998), o mesmo resultado foi obtido por Kumar et al. (2008) estudando Kappaphycus alvarezii Doty (Doty) ex P.C. Silva. Outras algas vermelhas também não demonstraram boas atividades antioxidantes para o DPHH como Chondria crassicaulis Harvey (Huang \& Wang, 2004) e espécies dos gêneros Laurencia J.V. Lamouroux e Chondrophycus (J. Tokida \& Y. Saito) Garbary \& J.T. Harper (Anggadiredja et al., 1997; Yan et al., 1998; Takamatsu et al., 2003; Kim et al., 2005; Zubia \& Robledo, 2007).

Para $P$. capillacea foi observada atividade antioxidante pelo método do Folin na condição controle e nao houve indução ou efeito no aumento da quantidade de luz. Resultados semelhantes foram obtidos por Guarino (2003), o autor avaliou a resposta da alga parda $S$. zonale quanto à produção de polifenóis sob diferentes regimes de irradiância, o experimento teve a duração de 10 dias e foram definidos três níveis de irradiância $(5,35$ e $100 \mu$ mol fótons. $\mathrm{m}^{-2} \cdot \mathrm{s}^{-1}$ ). No experimento $S$. zonale não foi observado que o aumento de irradiância promove-se alterações nos teores de polifenóis. Por outro lado, Torres et al. (2014) avaliaram 
o teor de fenólicos na macroalga vermelha $G$. tenuifrons sob três intensidades de irradiância $\left(60,600\right.$ e $1.000 \mu \mathrm{mol}$ fótons. $\left.\mathrm{m}^{-2} \cdot \mathrm{s}^{-1}\right)$. Nos resultados obtidos pelos autores, o tratamento de menor intensidade estimulou a produção de fenólicos em seis dias. No tratamento de 600 $\mu$ mol fótons. $\mathrm{m}^{-2} \cdot \mathrm{s}^{-1}$ houve, no primeiro dia, um aumento de $44 \%$ das substâncias fenólicas. Ao longo dos outros dias de cultivo sob esta intensidade luminosa, o teor de substâncias fenólicas continuou aumentando, atingindo a maior concentração após sete dias. No tratamento de $1.000 \mu \mathrm{mol}$ fótons. $\mathrm{m}^{-2} . \mathrm{s}^{-1}$, o teor das substâncias fenólicas seguiu o mesmo padrão observado em $600 \mu \mathrm{mol}$ fótons. $\mathrm{m}^{-2} \cdot \mathrm{s}^{-1}$. Estes resultados indicaram que o teor de substâncias fenólicas em G. tenuifrons respondeu ao aumento da intensidade de luz e a resposta para produção destes compostos foi rápida.

Apesar de possuir um baixo valor de equivalente padrão para o conteúdo de fenólicos, o extrato metanólico de $P$. capillacea tende a ser mais eficiente quando comparado às algas do gênero Gracilaria Greville, Gracilaria birdiae E.M. Plastino \& E.C. Oliveira, Gracialria cornea J. Agardh, rodófitas de amplo interesse econômico e da alga parda Eisenia bicyclis (Kjellman) Setchell (ver resultados Tabela 5).

Dessa forma, os resultados do presente estudo indicam que $P$. capillacea apresenta poder redutor, no entanto, não é possível afirmar se esta ação estaria relacionada à presença de substâncias fenólicas. Provavelmente devido ao fato de P. capillacea ser uma macroalga vermelha, esse tipo de composição não é característico deste grupo de algas. A explicação mais plausível para esta ação seria estar correlacionado com polissacarídeos, que também possuem ação redutora e podem ser detectados pelo método do Folin-Ciocalteu.

Quando comparada com outras Gelidiales, como G. amansii, no trabalho de Lee \& Shiu (2009) P. capillacea apresentou maior quantidade de antioxidantes sob radiação UVB, tais substâncias atuam como filtros de radiação e, adicionalmente, reduziriam a formação de espécies reativas de oxigênio de forma indireta. Os autores concluíram que $P$. capillacea foi capaz de reduzir sua sensibilidade à radiação UV-B, aumentando a capacidade de proteção solar e defesa antioxidante. Os resultados do presente estudo sugerem que $P$. capillacea apresenta a mesma capacidade frente a altas irradiâncias PAR, evidenciado pelos métodos ABTS, Folin e FRAP.

Os dados de PCA mostraram que as irradiâncias de 60 e $300 \mu$ mol fótons. $\mathrm{m}^{-2} \cdot \mathrm{s}^{-1}$ influenciaram o potencial antioxidante em P. capillacea de forma distinta. Pterocladiella 
capillacea mostrou fotoproteção frente à maior irradiância. Dessa forma, foi possível concluir que o aumento de luz foi capaz de aumentar as defesas antioxidantes da espécie.

Do ponto de vista global, $300 \mu \mathrm{mol}$ fótons. $\mathrm{m}^{-2} \cdot \mathrm{s}^{-1}$ não foi um estresse considerável para induzir mais atividade antioxidante nas concentrações testadas de extrato metanólico de P. capillacea. Devido à baixa atividade antioxidante (menor que 50\%), os ensaios de DPPH e quelante de metais mostraram-se inapropriados nas condições testadas para $P$. capillacea. No entanto, apesar do aumento de luz ter estimulado a defesas antioxidantes de $P$. capillacea, a concentração dos extratos está diretamente associada à eficiência dos mecanismos de fotoproteção frente ao estresse luminoso. Dessa forma, sugere-se testar concentrações acima de 13,3 mg.mL $\mathrm{mL}^{-1}$ de extrato bruto para os ensaios de DPPH, ABTS, quelante de metais e FRAP e para o método do Folin-Ciocalteu testar concentrações até $6 \mathrm{mg} \cdot \mathrm{mL}^{-1}$.

O potencial antioxidante de uma espécie sofre com a influência de diversos fatores como pressão de herbivoria, irradiância, profundidade, salinidade, nutrientes, estágio reprodutivo, entre outros (Connan et al., 2006). O conjunto dessas pressões altera qualitativamente e quantitativamente a produção de compostos antioxidativos. Dessa forma, estudos do potencial antioxidante associados à fisiologia de macroalgas devem ser intensificados, a fim de melhor elucidar tais mecanismos de defesa. Além disso, há um grande interesse aplicado em macroalgas como potenciais fontes de antioxidantes naturais.

As algas constituem cerca de $25 \%$ da dieta japonesa tradicional (Skibola, 2004). A baixa incidência de doenças crônicas em japoneses, comparadas às pessoas com baixa ingestão de algas, vem chamando atenção, sendo esta atribuída às diferenças na dieta entre as populações (Yuan \& Walsh, 2006). Dessa forma, as algas apresentam um potencial fantástico como suplemento alimentar com antioxidantes naturais.

Neste estudo, verificou-se que $P$. capillacea é fonte natural de antioxidantes e mostrou boa atividade para os métodos de ABTS, Folin-Ciocalteu e FRAP, tornando-a uma fonte potencial interessante de antioxidantes como suplemento funcional. Assim, sugere-se aprofundar os estudos a fim de avaliar a capacidade bioativa desta espécie. 


\section{Referências bibliográficas}

Aguilera J.; Dummermuth A.; Karsten U.; Schriek R.; Wiencke C. 2002. Enzymatic defences against photooxidative stress induced by ultraviolet radiation in Arctic marine macroalgae. Polar Biol. 25: 432-441.

Airanthi MKWA.; Hosokawa M.; Miyashita K. 2011. Comparative antioxidant activity of edible Japanese brown seaweeds. J. Food Sci. 76: 104-111.

Alencar DB.; Silva SR.; Pires-Cavalcante KMS.; Lima RL.; Pereira Júnior FN.; Sousa MB.; Saker-Sampaio S. 2014. Antioxidant potential and cytotoxic activity of two red seaweed species, Amansia multifida and Meristiella echinocarpa, from the coast of Northeastern Brazil. An. Acad. Bras. de Ciênc. 86: 251-263.

Anggadiredja J.; Andyani R.; Hayati M. 1997. Antioxidant activity of Sargassum polycystum (Phaeophyta) and Laurencia obtusa (Rhodophyta) from Seribu Islands. J. Appl. Phycol. 9: 477-479.

Burritt DJ.; Larkindale J.; Hurd CL.2002. Antioxidant metabolism in the intertidal red seaweed Stictosiphonia arbuscula following desiccation. Planta 215: 829-838.

Brand-Williams W.; Cuvelier ME.; Berset C. 1995. Use of a free radical method to evaluate antioxidant activity. Food Sci. Technol. 28: 25-30.

Brito ES.; Morais SM.; Sampaio CDG.; Saura-calixto FD. 2006. Metodologia científica: determinação da atividade antioxidante total em frutas pelo método de redução do ferro (FRAP). Embrapa 3-6p.

Costa LS. Atividades biologicas de polissacarideos sulfatados extraídos da alga vermelha gracilaria caudata. 2008. Dissertação de mestrado. Departamento de bioquímica. Universidade Federal do Rio Grande do Norte. Natal. 70p.

Connan S.; Delisle F.; Deslandes E.; Ar Gall E. 2006. Intra-thallus phlorotannin content and antioxidant activity in Phaeophyceae of temperate waters. Bot. Mar. 49: 34-46.

Cox S.; Abu-Ghannam N.; Gupta S. 2010. An assessment of the antioxidant and antimicrobial activity of six species of edible Irish sea-weeds. Int. Food Res. 17: 205-220.

Chakraborty K.; Joseph D.; Praveen NK. 2015. Antioxidant activities and phenolic contents of three red seaweeds (Division: Rhodophyta) harvest from Gulf of Mannar of Peninsular India. J. Food Sci. Technol. 52: 1924-1935.

Chen Z.; Bertin R.; Froldi G. 2013. EC 50 estimation of antioxidant activity in $\mathrm{DPPH}^{\bullet}$ assay using several statistical programs. Food Chem. 138: 414-420. 
Chernane H.; Mansori M.; Latique S.; El Kaoua. 2014. Evaluation of antioxidant capacity of methanol extract and its solvent fractions obtain from four moroccan macroalfae species. Euro. J. Sci. 10: 35-48.

Chirinos R.; Rogez H.; Campos D.; Pedreschi R.; Larondelle Y. 2007. Optimisation of extraction conditions of antioxidant phenolic compounds from mashua (Tropacolum tuberosum Ruiz et Pavon) tubers. Separation an purification. Technology 55: 217-225.

Choo K-S.; Snoeijs P.; Pedersén M. 2004. Oxidative stress tolerance in the filamentous green algae Cladophora glomerata and Enteromorpha ahlneriana. J. Exp. Mar. Biol. Ecol. 298: 111-123.

Edwards P. 1970. Illustrated guide to the seaweeds and sea grasses in the vicinity of Porto Aransas, Texas. Contr. Mar. 15: 1-228.

Ganesan P.; Kumar CS.; Bhaskar N. 2008. Antioxidant properties of methanol extract and its solvent fractions obtained from selected Indian red seaweeds. Bioresource Technol. 99: $2717-2723$.

Guarino AG. 2013. Variabilidade e atuação defensiva de polifenóis em macroalgas pardas. Tese de Doutorado. Universidade Federal Fluminense. Rio de Janeiro. 122p.

Gupta S.; Abu-Ghannam N. 2011. Bioactive potential and possible health effects of edible brown seaweeds. Trends Food Sci. Tech. 22: 315-326.

Halliwell B.; Whiteman M. 2004. Measuring reactive species and oxidative damage in vivo and in cell culture: How should you do it and what do the results means. Br. J. Pharmacol. 142: 231-255.

Halliwell B.; Gutteridge JMC. 2006. Free Radicals in Biology and Medicine. 4 ed. New york: Oxford University Press. 704p.

Harb TB.; Torres PB.; Pires JS.; Dos Santos DYAC.; Chow F. 2016. Ensaio em microplaca do potencial antioxidante através do sistema quelante de metais para extratos de algas. Instituto de Biociências, Universidade de São Paulo. ISBN 978-85-85658-63-2 1-5.

Huang HL.; Wang BG. 2004. Antioxidant capacity and lipophilic content of seaweeds collected from the Qingdao coastline. J. Agric. Food Chem. 52: 4993-4997.

Kim SJ.; Woo S.; Yun H.; Yum S.; Choi E.; Do JR.; Jo JH.; Kim D.; Lee S.; Lee TK. 2005. Total phenolic contents and biological activities of Korean seaweed extracts. Food Sci. Biotechnol. 14: 798-802.

Kiran VM; Murugesan S. 2014. In vitro Antioxidant activity of silver nano-particles from Colpomenia sinuosa and Halymenia poryphyroides. World J. Pharm. Sci. 2: 817-820. 
Kumar KS.; Ganesan K.; Rao PVS. 2008. Antioxidant potential of solvent extracts of Kappaphycus alvarezii (Doty) Doty - An edible seaweed. Food Chem. 107: 289- 295.

Lee TM.; Shiu CT. 2009. Implications of mycosporine-like amino acid and antioxidant defenses in UV-B radiation tolerance for the algae species Pterocladiella capillacea and Gelidium amansii. Mar. Environ. Res. 67: 8-16.

Matanjun P.; Mohamed S.; Mustapha NM.; Muhammad K.; Ming CH. 2008. Antioxidant activities and phenolics content of eight species of seaweed from north Borneo. J. Appl. Phycol. 20: 367-373.

Matsukawa R.; Dubinsky Z.; Kishimoto E.; Masakki K.; Masuda,Y.; Takeuchi T. A comparison of screening methods for antioxidant activity in seaweeds. J. Appl. Phycol. 9: 29-35.

Min B.; McClung AM.; Chen M-H. 2011. Phytochemicals and antioxidant capacities in rice brans of different color. J. Food Sci. 76: C117-26. Disponível em< http://www.ncbi.nlm.nih.gov/pubmed/21535639> Accesso em 15/04/2016.

O' Sullivan AM.; O'Callaghan YC.; O'Grady MN.; Queguineur B.; Hanniffy D.; Troy DJ.; Kerry JP.; O’Brien NM. 2011. In vitro and cellular antioxidant activities of seaweed extracts prepared from five brown seaweeds harvested in spring from the west coast of Ireland. Food Chem. 126: 1064-1070.

Rijstenbil JW.; Coelho SM.; Eijsackers M. 2000. A method for the assessment of lightinduced oxidative stress in embryos of fucoid algae via confocal laserscan microscopy. Mar. Biol. 137: 763-774.

Rocha FD.; Pereira RC.; Kaplan MAC.; Teixeira VL. 2007. Natural products from marine seaweeds and their antioxidant potential. Rev. Bras. J. Farmacogn. 17: 631-639.

Ruperez, P.; Ahrazem, O.; Leal, JA. 2002. Potential antioxidant capacity of sulfated polysaccharides from the edible marine brown seaweed Fucus vesiculosus. J. Agric. Food Chem. 50: 840-845.

Roginsky V.; Lissi EA. 2005. Review of methods to determine chain-breaking antioxidant activity in food. Food Chem. 92: 235-254.

Rufino M.; Alves R. 2007. Metodologia científica: determinação da atividade antioxidante total em frutas pela captura do radical livre DPPH. Disponível em < http://agris.fao.org/agrissearch/search.do?f=2012/BR/BR2012102700027.xml;BR200714 26953>.

Embrapa

$3-6 p$. 
Rupérez P.; Ahrazem O.; Leal JÁ. 2002. Potential antioxidant capacity of sulfated polysaccharides frrom the edible marine brown seaweed Fucus vesiculosus. J. Agric. Food Chem. 50: 840-845.

Singleton V.; Rossi J. 1965. Colorimetry of total phenolics with phosphomolybdicphosphotungstic acid reagents. Am. J. Enol. Viticult. 16: 144-158.

Sousa MB.; Pires KMS.; Alencar DB.; Sampaio AH.; Saker-Sampaio S. 2008. $\alpha$-, $\beta$-caroteno e $\alpha$-tocoferol em algas marinhas in natura. Ciênc. Tecnol. Aliment. 28: 953-958p.

Souza BW.; Cerqueira MA.; Martins JT.; Quintais MAC.; Ferreira ACS.; Teixeira JA.; Vicente AA. 2011. Antioxidant potential of two red seaweeds from the Brazilian coast. $J$. Agric. Food Chem. 59: 5589-5594.

Shiu CT.; Lee TM. 2005. Ultraviolet-B-induced oxidative stress and responses of the ascorbate-glutathione cycle in a marine macroalga Ulva fasciata. J. Exp. Bot. 56: 28512865.

Skibola C. 2004. The effect of Fucus vesiculosus, an edible brown seaweed, upon menstrual cycle lenght and hormonal status in three pre-menopausal women: a case report. BMC Complement. Altern. Med. 4: 10-17.

Takamatsu S.; Hodges TW.; Rajbhandari I.; Gerwick WH.; Hamann MT.; Nagle DG. 2003. Marine natural products as novel antioxidant prototypes. J. Nat. Prod. 66: 605-608.

Tariq A.; Ara J.; Sultana V.; Ehteshamul-Haque S.; Athar M. 2011. Antioxidant potential of seaweeds occurring at Karachi coast of Pakistan. J. Appl. Bot. Food Qual. 84: 207-212.

Torres BP. 2012. Análise de pigmentos fotossintetizantes e substâncias fenólicas em Gracilariopsis tenuifrons (C. J. Bird \& E. C. Oliveira) Fredericq \& Hommersand em diferentes intensida- des de luz. Dissertação de mestrado. Instituto de Biociências. Universidade de São Paulo. São Paulo. 104p.

Urrea-Victoria V.; Pires JS.; Torres PB.; Dos Santos DYAC.; Chow F. 2016. Ensaio antioxidante em microplaca do poder de redução do ferro (FRAP) para extratos de algas. Instituto de Biociências, Universidade de São Paulo. ISBN 978-85-85658-62-5 1-6.

Ursi S.; Plastino EM. 2001. Crescimento in vitro de linhagens de coloração vermelha e marrom-esverdeada clara de Gracilaria sp. (Gracilariales, Rhodophyta) em dois meios de cultura: análise de diferentes estádios reprodutivos. Rev. Bras. Bot. 24: 587-594.

Vinayak RC.; Sabu SA,; Chatterji A. 2011a. Bio-prospecting of a few brown seaweeds for their cytotoxic and antioxidant activities. Evid. Based Complem. Alternat. Med. 5: 1-9. 
Vinayak RC.; Sudha SA.; Chatterji A. 2011b. Bio-screening of a few green seaweeds from India for their cytotoxic and antioxidant potential. J. Sci. Food Agric. 91: 2471-2476.

Wang T.; Jónsdóttir R.; Ólafsdóttir G. 2009. Total phenolic compounds, radical scavenging and metal chelation of extracts from Icelandic seaweeds. Food Chem. 116: 240-8.

Waterman PG.; Mole S. 1994. Extraction and chemical quantification. In: Analysis of phenolic plant metabolites. Blac. Sci. Public. 11: 83-85.

Wojcik M.; Burzynska-Pedziwiatr I.; Wozniak LA. 2010. A review of natural and synthetic antioxidants important for health and longevity. Curr. Med. Chem. 17: 3262-3288.

Yan XJ.; Nagata T.; Fan X. 1998. Antioxidative activities in some common seaweeds. Plant Food Hum. Nutr. 52: 253-262.

Yang H.; Dong Y.; Du H.; Shi H; Peng Y.; Li X. 2011. Antioxidant compounds from propolis collected in Anhui, China. Molecules 16: 3444-55.

Yuan YV.; Walsh NA. 2006. Antioxidante and antiproleferative activies of extracts from a variety of edible seaweeds. Food Chem. Toxicol. 44: 1144-1150.

Zubia M.; Roblelo D. 2007. Atioxidants activity in tropical marine macroalgae from the Yucatan Peninsula. J. Appl. Phycol. 19: 449-458. 


\section{Capítulo III}

\section{Composição de aminoácidos tipo micosporinas na alga vermelha \\ Pterocladiella capillacea (Rhodophyta, Gelidiales) e indução por luz}

\section{Mycosporine-like amino acids composition in the red alga Pterocladiella capillacea (Rhodophyta, Gelidiales) and ligth induction}

\section{Resumo}

Aminoácidos do tipo micosporinas (MAAs) são compostos altamente polares, de baixo peso molecular que absorvem radiação ultravioleta. Em macroalgas, atuam como substâncias fotoprotetoras com capacidade antioxidante e como reservatório de nitrogênio frente a condições de estresse. A concentração e diversidade de MAAs estão relacionadas com as condições ambientais, como exposição à irradiância e disponibilidade de nutrientes. A distribuição geográfica das algas também pode estimular ou inibir a síntese de MAAs. Esses compostos têm sido comumente associados à fotoproteção de radiação UV, no entanto, estudos mostram que PAR também influencia o teor de MAAs. O objetivo deste trabalho foi caracterizar a composição e variação de MAAs na Rhodophyta Pterocladiella capillacea sob a influência das irradiâncias 60 e $300 \mu \mathrm{mol}$ fótons. $\mathrm{m}^{-2} \cdot \mathrm{s}^{1}$ durante oito dias de experimento. Os extratos foram analisados em cromatógrafo líquido de alta eficiência (CLAE) e a identificação dos MAAs foi realizada comparando os tempos de retenção e os perfis de absorção das amostras com dados previamente identificados em CLAE-IES-EM. Pterocladiella capillacea apresentou apenas o MAA chinorina. A quantidade de chinorina não variou significativamente entre os tratamentos, porém, foi observado aumento na irradiância de 300 $\mu$ mol fótons. $\mathrm{m}^{-2} \cdot \mathrm{s}^{-1}$ em 24 horas. $\mathrm{O}$ aumento de PAR estimulou a síntese de MAAs em $P$. capillacea e a espécie mostrou-se ser uma fonte muito interessante de chinorina, este MAA pode ser isolado e utilizado como padrão pela indústria na produção de compostos puros ou como ingredientes de filtros solares e cosméticos. 


\begin{abstract}
Mycosporine-like amino acids (MAAs) are highly polar compounds UV-absorbing, with low molecular weight. In macroalgae, they act as photoprotective substances with antioxidant capacity and as nitrogen reserve under to stress conditions. The concentration and diversity of MAAs are related to environmental conditions such as exposure to irradiance and nutrient availability. The geographical distribution of algae may also stimulate or inhibit the synthesis of MAAs. These compounds have been commonly associated with UV photoprotection, however, studies show that PAR also influences the MAAs content. The aim of this study was to characterize the composition and variation of MAAs in Rhodophyta Pterocladiella capillacea under the influence of the irradiances 60 and $300 \mu \mathrm{mol}$ fótons. $\mathrm{m}^{-2} \cdot \mathrm{s}^{-1}$ for eight days of experiment. The extracts were analyzed by high performance liquid chromatograph (HPLC) and the identification of MAAs was done by comparing the retention times and absorption profiles of the samples with previously identified datas in HPLC-ESI-MS. Pterocladiella capillacea only presented the MAA chinorina. The amount of chinorina did not change significantly among treatments, however, there was an increase in irradiance of $300 \mu \mathrm{mol}$ fótons. $\mathrm{m}^{-2} \cdot \mathrm{s}^{-1}$ in 24 hours. The increase in PAR stimulated MAAs synthesis in $P$. capillacea and this specie proved to be a very interesting source of chinorina, this MAA may be isolated and used as standard in industry for the production of pure compounds or as sunscreen and cosmetic ingredients.
\end{abstract}




\section{Introdução}

Para garantir a sobrevivência em ambientes marinhos, as macroalgas que habitam na zona entre marés precisam superar diversos obstáculos ambientais, pois sofrem com alta variação de fatores abióticos. Nesse contexto, a radiação solar (luz visível e radiação UV) é um dos principais fatores que afeta a fisiologia desses organismos. Durante a maré baixa, diversos mecanismos de fotoregulação são ativados a fim de evitar a fotoxidação pela exposição à alta intensidade luminosa (Lobban \& Harrison, 2000; Connan et al., 2007). A fim de se adaptarem rapidamente às diferentes condições ambientais, as macroalgas desenvolveram ao longo da evolução mecanismos de proteção química, dentre eles aminoácidos do tipo micosporinas (MAAs, do inglês Mycosporine-like Amino Acids) (Chew et al., 2008; Plaza et al., 2008). Os MAAs são compostos que absorvem dentro da faixa do UV, caracterizam-se por possuírem um único pico com absorção máxima entre 310 e 360 nm (Singh et al., 2008 ).

Em macroalgas, MAAs atuam como substâncias de fotorregulação e sua produção é fortemente influenciada pelo aumento de PAR (do inglês Photosynthetically Active Radiation; 400-700 nm) e radiação UV-A ou UV-B (Carreto \& Carignan, 2011). Dessa forma, geralmente é observada uma correlação positiva entre radiação e produção de MAAs (Lee \& Shiu, 2009; Carreto \& Caignan, 2011; Barre et al., 2014), com possibilidade de indução de MAAs em períodos curtos de tempo.

Alguns estudos mostram que o acúmulo de MAAs está associado à elevada fotoestabilidade in vitro (Conde et al., 2000; Conde et al., 2004) e in vivo (Adams \& Schick, 2001), indicando que estes metabólitos são compostos fotoprotetores eficazes contra radiação, especialmente por sua capacidade de absorver comprimentos de onda curtos. A composição dessas substâncias pode variar de acordo com temperatura, luz, nutrientes, profundidade e latitude, além de variar entre filos e espécies (Huovinen et al., 2004; Korbee-Peinado, 2004; Torres et al., 2015; Torres et al., 2016). Algas vermelhas demostram acumular mais MAAs do que as algas pardas e verdes (Singh et al., 2008; Carreto \& Carrignan, 2011; Marques, 2015).

Em macroalgas vermelhas, os MAAs são em geral a proteção mais eficaz contra os efeitos combinados de temperatura, irradiância e estresse oxidativo por serem eficientes antioxidantes e dissipadores de calor, além de contribuir para o equilíbrio osmótico sob estresse iônico (De La Coba et al., 2009; Yoshiki et al., 2009; Yuan et al., 2009; Barre et al., 2014). 
Poucos estudos avaliaram o estímulo de intensidade luminosa e conteúdo de MAAs em macroalgas. Kräbs et al. (2002) observaram um incremento no teor de MAAs associado ao aumento de PAR em Chondrus cripus Stackhouse. Na mesma alga, Karsten et al. (1998) reportaram aumento das MAAs palitina, chinorina e palitinol sob alta PAR. Resultados semelhantes foram verificados em Porphyra leucosticta Thuret in Le Jolis (Korbee et al., 2005). Recentemente, Torres et al. (2015) e Torres et al. (2016) estudaram o teor de MAAs em Gracilariopsis tenuifrons (C.J. Bird \& E.C. Oliveira) Fredericq \& Hommersand em diferentes regimes de irradiância e verificaram que o aumento de PAR não alterou a composição qualitativa de MAAs, no entanto, foi observado diminuição quantitativa na irradiância controle $\left(60 \mu \mathrm{mol}\right.$ fótons. $\left.\mathrm{m}^{-2} . \mathrm{s}^{-1}\right)$ e aumento de $20 \%$ no teor de MAAs com o incremento de PAR. Tais resultados sustentam a função fotoprotetora atribuída a esses compostos. Assim, o objetivo desta pesquisa foi identificar e quantificar os aminoácidos do tipo micosporinas (MAAs) de Pterocladiella capillacea (S.G. Gmelin) Santelices \& Hommersand e estudar suas alterações quali e quantitativa após exposição a diferentes intensidades de PAR.

\section{Material e métodos}

Pterocladiella capillacea foi coletada na região entremarés do costão rochoso da Praia

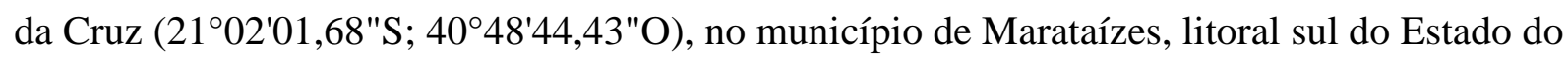
Espírito Santo, Brasil. Após triagem e limpeza, porções apicais foram mantidas em cultivo no Laboratório de Algas Marinhas "Édison José de Paula" da Universidade de São Paulo por uma semana para aclimatação, na proporção de $3 \mathrm{~g}$ de massa fresca (MF) para cada $1 \mathrm{~L}$ de meio de cultivo em água do mar esterilizada, 32 ups, enriquecida com solução de nutriente von Stosch 100\% (Ursi \& Plastino (2001) modificado de Edwards (1970)), $25 \pm 1^{\circ} \mathrm{C}, 60 \pm 5$ $\mu$ mol fótons. $\mathrm{m}^{-2} \cdot \mathrm{s}^{-1}$, fotoperíodo de $14 \mathrm{~h}$ de luz e $10 \mathrm{~h}$ de escuro e aeração em períodos intermitentes de 30 min ligado e 30 min desligado.

Após o período de aclimatação, porções apicais de $5 \mathrm{~cm}$ de comprimento foram submetidas às mesmas condições descritas acima durante oito dias (período experimental), exceto na proporção experimental de biomassa/volume de meio de cultura $(1 \mathrm{~g}$ MF por $1 \mathrm{~L}$ de meio de cultivo) e na irradiância experimental $(\mathrm{n}=5)$ : (a) $60 \pm 5 \mu \mathrm{mol}$ fótons. $\mathrm{m}^{-2} \cdot \mathrm{s}^{-1}$ (controle) e (b) $300 \pm 5 \mu \mathrm{mol}$ fótons. $\mathrm{m}^{-2}$. $\mathrm{s}^{-1}$. A adição de meio de cultura foi realizada antes de iniciar o experimento (tempo zero; t0) e após uma semana de experimento. Este último com o 
objetivo de avaliar a capacidade de recuperação após suprimento de nutrientes. As amostras de MAAs foram avaliadas nos dias $0,1,3,5,7$ e 8 ( $\mathrm{t} 0, \mathrm{t} 1, \mathrm{t} 3$, $\mathrm{t} 5$, $\mathrm{t} 7 \mathrm{e} \mathrm{t} 8$, respectivamente).

Para cada uma das irradiâncias (60 e $300 \mu \mathrm{mol}$ fótons. $\mathrm{m}^{-2} \cdot \mathrm{s}^{-1}$ ) e cada um dos tempos experimentais (seis tempos) foram cultivados cinco repetições em frascos separados, considerando-as como cinco repetições independentes e evitando assim a dependência temporal das amostras. No total, o experimento foi constituído por 60 frascos.

Cerca de $200 \mathrm{mg}$ MF de amostra para cada tratamento $(\mathrm{n}=5$; irradiância versus tempo) foram congeladas em nitrogênio líquido e armazenadas em ultrafreezer $\left(-80^{\circ} \mathrm{C}\right)$ para posteriores análises. As amostras congeladas foram trituradas em nitrogênio líquido e extraídas três vezes por $2 \mathrm{~h}$ a $45^{\circ} \mathrm{C}$ com $1 \mathrm{~mL}$ de metanol $25 \%$. Os sobrenadantes das três extrações foram reunidos e secos em estufa a $40^{\circ} \mathrm{C}$ por dois dias para cálculo do rendimento (ver detalhes no Anexo IV Tabelas AIV 18-19). Os extratos, em concentração de 5 mg.mL $\mathrm{mL}^{-1}$ ressuspendido em metanol grau CLAE, foram analisados em cromatógrafo líquido de alta eficiência (CLAE) Hewlett Packard modelo HP1260 (EUA) baseando-se no método de Torres et al. (2015) e modificado de Hartmann et al. (2015). O sistema cromatográfico utilizou coluna Zorbax RX-SIL (fase normal), com cromatogramas processados em $\lambda=270,320,330$ e $370 \mathrm{~nm}$; com fase móvel de gradiente entre A = acetonitrila:acetato de amônio $5 \mathrm{mM}$ (9:1) e $\mathrm{B}=$ acetonitrila:acetato de amônio $5 \mathrm{mM}$ (1:1), com a seguinte programação: 0 min - 20\% A; 15 min - 55\% A; 16 min - 20\% A; fluxo de 1 mL.min ${ }^{-1}$; volume de injeção de $5 \mu \mathrm{L}$; duração da corrida de 15 min. A identificação dos MAAs presentes no extrato de $P$. capillacea foi realizada comparando os tempos de retenção e os perfis de absorção das amostras com dados previamente identificados em CLAE-IES-EM de Gracilariopsis tenuifrons (C.J. Bird \& E.C. Oliveira) Fredericq \& Hommersand (Torres et al., 2016). As análises de MAAs foram realizadas no Laboratório de Fitoquímica do IB-USP em colaboração com a Dra. Deborah Y.A.C. dos Santos. Para a quantificação dos MAAs foi utilizada uma curva padrão de porphyra-334 com concentrações de 5,9 a $23 \mu \mathrm{g} \cdot \mathrm{mL}^{-1}$, que correspondem as massas de 0,12 a $0,48 \mu \mathrm{g}$. A equação da reta foi $\mathrm{y}=0,1135,1 \mathrm{x}\left(\mathrm{R}^{2}=0,99\right)$. Optou-se por utilizar a curva padrão de porphyra-334, pois não foi possível obter o isolado de chinorina em quantidade suficiente para realizar a curva padrão, MAA presente em P. capillacea. Além disso, porphyra-334 e chinorina são MAAs muito semelhantes, diferem em apenas uma cadeia orgânica em suas fórmulas moleculares. 
Os resultados foram avaliados mediante análise de variância (ANOVA) bifatorial e análise de comparações múltiplas pelo teste post-hoc de Newman-Keuls ( $<<0,05)$. Os dados foram previamente testados quanto à normalidade (teste de Kolmogorov-Smirnov) e homocedasticidade (teste de Bartlett), dentro de um intervalo de confiança de $95 \%$ ( $p<0,05)$. As análises estatísticas foram feitas com o programa Statistica 12 (ver detalhes em Anexo IV Tabela AIV 20).

\section{Resultados e discussão}

A Figura 35 apresenta os cromatogramas e os espectros de absorção em UV/vis dos padrões porphyra-334 (Fig. 35A-C) e chinorina (Fig. 35D-F) isolados da macroalga Gracilaria domingensis Sonder ex Dickie. Esses padrões foram utilizados para a identificação dos MAAs de $P$. capillacea. Os resultados do presente estudo indicaram apenas a presença do MAA chinorina nas amostras submetidas às irradiâncias de 60 e $300 \mu$ mol fótons.m $\mathrm{m}^{-2} \cdot \mathrm{s}^{-1}$. Assim, não houve diferença qualitativa no conteúdo de MAAs ao longo do tempo, nem entre as irradiâncias (dados não mostrados).
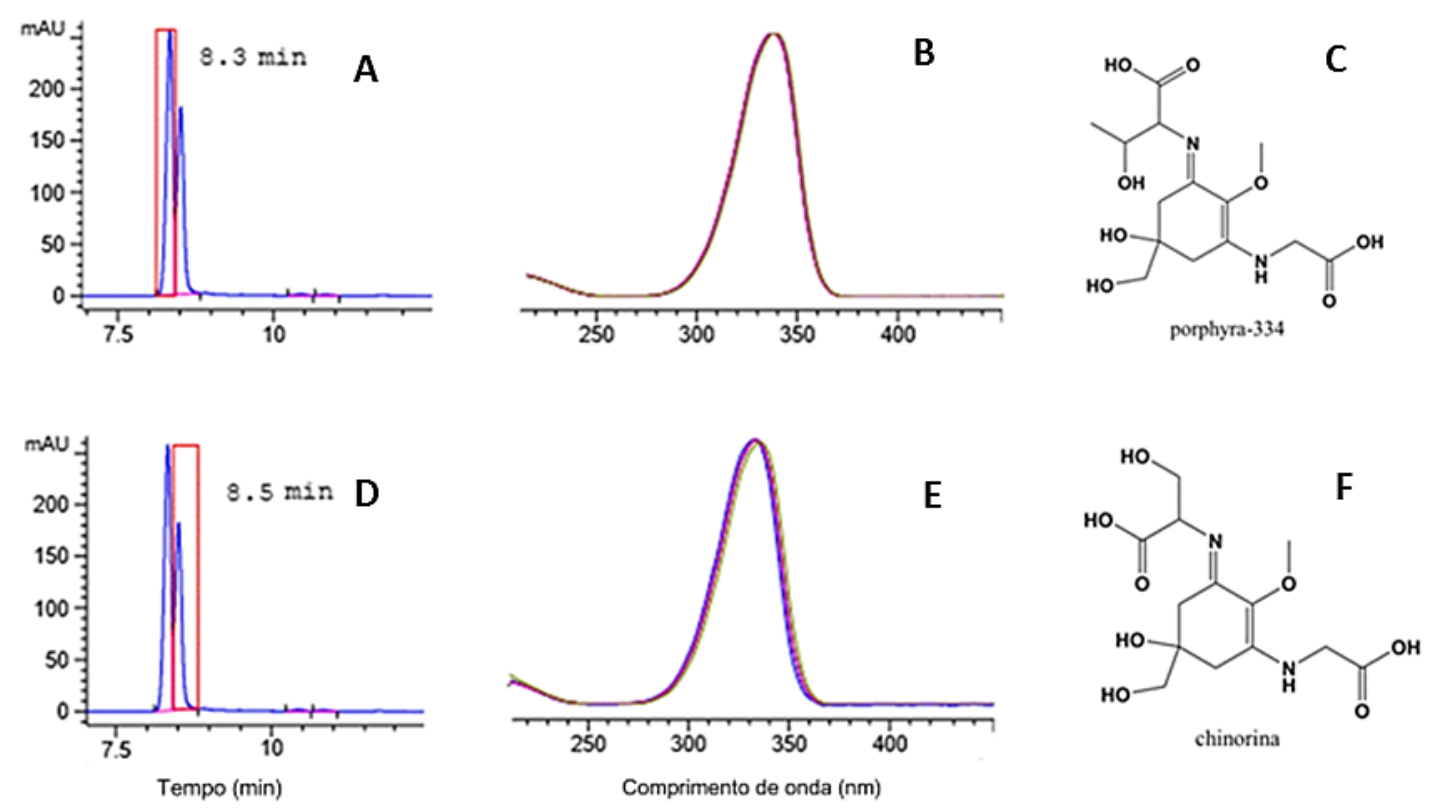

Figura 35. (A e D) Cromatogramas obtidos por CLAE, (B e E) espectros de absorção em UV/vis e (C e F) estruturas moleculares de porphyra-334 (A-C) e chinorina (D-F) de padrões isolados de Gracilaria domingensis. 
A Figura 36A mostra o cromatograma obtido em CLAE de uma amostra de $P$. capillacea submetida a $60 \mu \mathrm{mol}$ fótons. $\mathrm{m}^{-2} . \mathrm{s}^{-1}$, com um pico único em $8,5 \mathrm{~min}$. O espectro de UV/vis corrobora a presença de MAA (Fig. 36B), sendo esta identificada como chinorina. Dessa forma, qualitativamente, $P$. capillacea apresentou número de tipos de MAAs inferior ao reportado na literatura para a espécie (Korbee, 2003; Lee \& Shiu, 2009; Gravem \& Adams, 2012; Marques, 2015).

Korbee (2003) coletou P. capillacea em diferentes latitudes na Espanha, a autora observou a presença de chinorina, palitina e asterina 330 em todos os indivíduos. No entanto, ainda que em baixas quantidades, a presença do MAA porphyra-334 foi encontrada em alguns organismos. Gravem \& Adams (2012) verificaram maior teor de chinorina e presença de palitina, asterina 330 e usujirene além de baixas quantidades de porphyra-334 em P.capillacea coletada na Califórnia.

No Japão, Lee \& Shiu (2009) registraram a presença de chinorina, porphyra-334 e palitinol para a mesma espécie, sendo porphyra-334 o MAA em maior quantidade. Essa composição de MAAs foi igual à encontrada por Marques (2015) para P. capillacea, no entanto, o teor de chinorina foi significativamente superior aos outros dois MAAs. A autora também encontrou traços da presença de asterina-330 na espécie. Nesse estudo, Marques (2016) analisou a composição de MAAs em macroalgas do Espírito Santo, sendo o maior estudo sobre o tema reportado para o litoral brasileiro até o momento, ao todo foram coletadas 32 espécies entre vermelhas, pardas e verdes e oito MAAs identificados.

A literatura aponta que chinorina e porphyra-334 são os MAAs mais comuns em macroalgas (Carreto \& Carignan, 2011). No entanto, porphyra-334, palitina, asterina 330, usujirene e palitinol, reportados em outros trabalhos para $P$. capillacea, não foram observados no presente estudo sob as condições experimentais estudadas. A variação qualitativa dos MAAs de $P$. capillacea encontradas neste estudo e na literatura disponível pode ser influenciada pela natureza da amostra, provenientes de locais e períodos diferentes, na qual as condições ambientais individuais podem alterar de forma significativa a composição de MAAs.

A diferença na composição e variação de MAAs pode ser devido à procedência da matrix algácea em estudo. Ou seja, amostras algáceas proveniente diretamente de coletas em campo podem ser qualitativa e quantitativamente diferentes na sua composição de MAAs que algas mantidas em laboratório. Algas de campo estão expostas a um amplo espectro de 
radiação solar, incluindo luz visível e radiação UV. Em laboratório, a condição luminosa se restringe a luz visível, dispensando a exposição à radiação UV, radiação essencial para estímulo de biossíntese de MAAs. Esta situação é corroborada pelo trabalho de Oren \& Gunde-Cimerman (2007), na qual as respostas em condições de alta irradiância podem ser inerentes a cada espécie ou estarem relacionadas com condições distintas de aclimatação, influência da qualidade, intensidade e tempo de exposição à luz.

Kräbs et al. (2002) mostraram que C. crispus teve alta capacidade para adaptar as concentrações qualitativa e quantitativas de MAAs sob radiação solar natural. Os autores aclimataram os talos em laboratório sob irradiância de $25 \mu \mathrm{mol}$ fótons.m $\mathrm{m}^{-2} \cdot \mathrm{s}^{-1}$ e depois deixaram expostos por 12 dias sob diferentes filtros/comprimentos de onda de radiação solar natural. Os padrões qualitativos e quantitativos variaram de acordo com a distribuição do espectro. Além disso, as bandas de ondas eficientes para síntese de MAA alteraram de acordo com o MAA. A radiação UVB teve efeito negativo para o acúmulo de chinorina e palitina, enquanto comprimentos de onda curtos UVA tiveram eficiência na síntese desses MAAs. Por outro lado, asterina-330, paliteno e palitinol foram mais sintetizados em comprimentos de onda UVB. Em laboratório sob irradiância PAR $\left(25 \mu \mathrm{mol}\right.$ fótons. $\left.\mathrm{m}^{-2} \cdot \mathrm{s}^{-1}\right)$, os espécimes de $C$. crispus possuíram apenas vestígios de palitina e sintetizaram cinco MAAs diferentes.

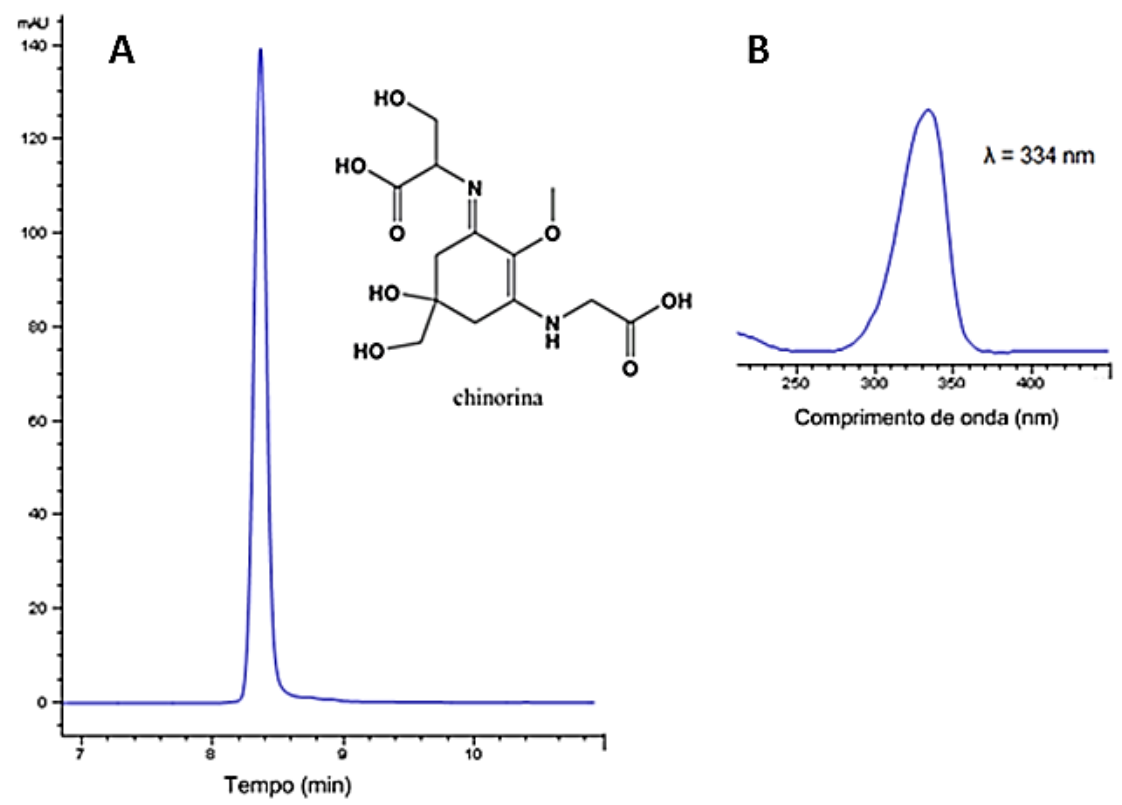

Figura 36. (A) Cromatograma do extrato metanólico de Pterocladiella capillacea submetida a $60 \mu \mathrm{mol}$ fótons. $\mathrm{m}^{-2} \cdot \mathrm{s}^{-1}$, com destaque para um único pico em 8,5 min e a estrutura molecular do MAA identificado (chinorina). (B) Espectro de absorção em UV/vis do pico de chinorina em $334 \mathrm{~nm}$. 
A presença exclusiva de chinorina em $P$. capillacea sob as condições experimentais estudadas indica que a espécie pode ser uma fonte interessante de MAAs, visto que esta MAA pode ser isolada e utilizada como padrão pela indústria de diferentes formas, seja na produção de compostos puros ou até mesmo na utilização de seus extratos como ingredientes de filtros solares e cosméticos. A espécie alvo do presente estudo possui grande importância econômica, em especial, por produzir um ágar de ótima qualidade. Assim, a extração de MAAs poderia constituir outra alternativa de exploração como produto natural e melhorar a importância comercial de $P$. capillacea.

Estudos recentes têm demonstrado que os MAAs porphyra-334 e chinorina podem ser comercializadas com sucesso em formulações para uso tópico (De La Coba, 2007; De la Coba et al., 2009; López Figueroa et al., 2010). Além disso, apresentam valores de FPS (Fator de Proteção Solar) semelhante a cremes que contêm filtros solares comerciais protetores contra UVA e UVB (De La Coba et al., 2009). Outras aplicações de MAAs podem incluir também aditivos fotoestabilizantes em plásticos, vernizes e tintas. Como por exemplo, em tintas para automóveis, onde são submetidos a exposições intensas e prolongadas à luz do sol (Torres et al., 2006; Sampedro, 2011).

Além do estudo da composição de MAAs na alga $P$. capillacea, o presente trabalho avaliou ao longo dos dias a variação quantitativa e qualitativa de MAAs submetida à irradiância de $300 \mu \mathrm{mol}$ fótons. $\mathrm{m}^{-2} . \mathrm{s}^{-1}$, resultados mostrados na Figura 37. Na quantificação de chinorina, expressa em equivalente de porphyra-334, foi possível observar que não houve variação ao longo do tempo para à irradiância de $60 \mu \mathrm{mol}$ fótons. $\mathrm{m}^{-2} \cdot \mathrm{s}^{-1} \mathrm{e}$ nem para $300 \mu \mathrm{mol}$ fótons. $\mathrm{m}^{-2} \cdot \mathrm{s}^{-1}$, exceto para o tempo $\mathrm{t} 1$. Nesse tratamento, o teor de chinorina aumentou rapidamente em $24 \mathrm{~h}$, mostrando diminuição e semelhança após esse período experimental (Fig. 37).

Ao comparar as duas irradiâncias, observou-se que a irradiância de $60 \mu$ mol fótons.m ${ }^{-}$ ${ }^{2} \cdot \mathrm{s}^{-1}$ não estimulou a síntese de MAAs, permancendo constante ao longo do tempo (Fig. 37). Em contrapartida, irradiância em $300 \mu \mathrm{mol}$ fótons. $\mathrm{m}^{-2} \cdot \mathrm{s}^{-1}$ propiciou o acúmulo de MAAs em 24 h. Estes resultados são diferentes dos reportados por Torres et al. (2015), trabalhando com G. tenuifrons, na qual os autores observaram aumento ao longo de todo o período experimental do MAA palitinol quando a irradiância foi aumentada de 60 para $600 \mu \mathrm{mol}$ fótons. $\mathrm{m}^{-2} \cdot \mathrm{s}^{-1}$. O aumento de chinorina em $P$. capillacea foi transiente, no entanto, essa 
resposta é interessante, pois indica a possibilidade de induzir a quantidade de MAAs sob exposição de PAR.

Outros estudos também reportaram a composição e variação de MAAs frente a diferentes regimes de luz. Torres et al. (2016) verificaram a presença de cinco MAAs em $G$. tenuifrons sob os regimes de 60, 600 e $1000 \mu \mathrm{mol}$ fótons. $\mathrm{m}^{-2} . \mathrm{s}^{-1}$. Quatro deles foram identificados como asterina-330, palitinol, paliteno e usujirene. O aumento do MAA palitinol foi correlacionado com a alta PAR, indicando a função fotoprotetora desses compostos.

Hoyer et al. (2002) verificaram a indução de MAAs em 18 macroalgas vermelhas sob três diferentes regimes de luz, irradiância PAR 5,4 W/m² $\left(25 \mu \mathrm{mol}\right.$ fótons. $\left.\mathrm{m}^{-2} \cdot \mathrm{s}^{-1}\right), \mathrm{PAR}+$ UVA $\left(4,1 \mathrm{~W} / \mathrm{m}^{2}\right)$ e PAR + UVA + UVB (0,5 W/m²). Dez das 18 macroalgas não apresentaram teor de MAAs em nenhuma condição testada. A incubação em diferentes condições de radiação resultou em diferenças quantitativas e qualitativas no conteúdo de MAAs. Quatro espécies obtiveram teores crescentes de MAAs sob os três diferentes tratamentos de radiação, duas espécies apresentaram maiores concentrações de MAAs sob PAR + UVA e outras duas espécies exibiram forte diminuição no conteúdo de MAAs sob PAR + UVR. Os autores não encontraram padrões consistentes para a indução de MAAs nas macroalgas coletadas, indicando que a produção e acumulação de MAAs em um indivíduo é um mecanismo muito flexível e específico da espécie.

Franklin et al. (1999) mostraram que os MAAs em C. crispus podem ser induzidos por PAR sozinho ou radiação UV. No entanto, somento quando PAR esteve presente os MAAs sintetizados foram semelhantes em quantidade e qualidade aos encontrados em campo. Outro fato interessante é que a indução por PAR mostou um padrão distinto, com a síntese inicial de chinorina, seguido por palitina e posteriormente declínio de chinorina. Por outro lado, a exposição a radiação UVR estimulou a síntese de chinorina, com menores quantidades de palitina.

Franklin et al. (2001) analisaram a indução de MAAs em C. crispus por luz vermelha, verde, azul e branca. O MAA palitina foi sintetizado nos talos submetidos à luz azul na mesma proporção dos talos controles (luz branca), em contrapartida os talos sob luz verde e vermelha apresentaram apenas vestígios de MAAs. Posteriormente, os autores avaliaram a capacidade fotossintetizante de $C$. crispus sob UV e observaram que os talos com MAAs foram mais resistentes do que aqueles sem estes compostos. O grupo verificou que a préexposição à luz azul, seguida por crescimento da espécie sob UVA levou a um aumento de 
sete vezes o teor de chinorina em comparação com os crescimento sob radiação UV sem prétratamento de luz azul. Os autores concluíram que C. crispus sintetizou de forma eficiente compostos fotoprotetores com o aumento do nível de radiação.

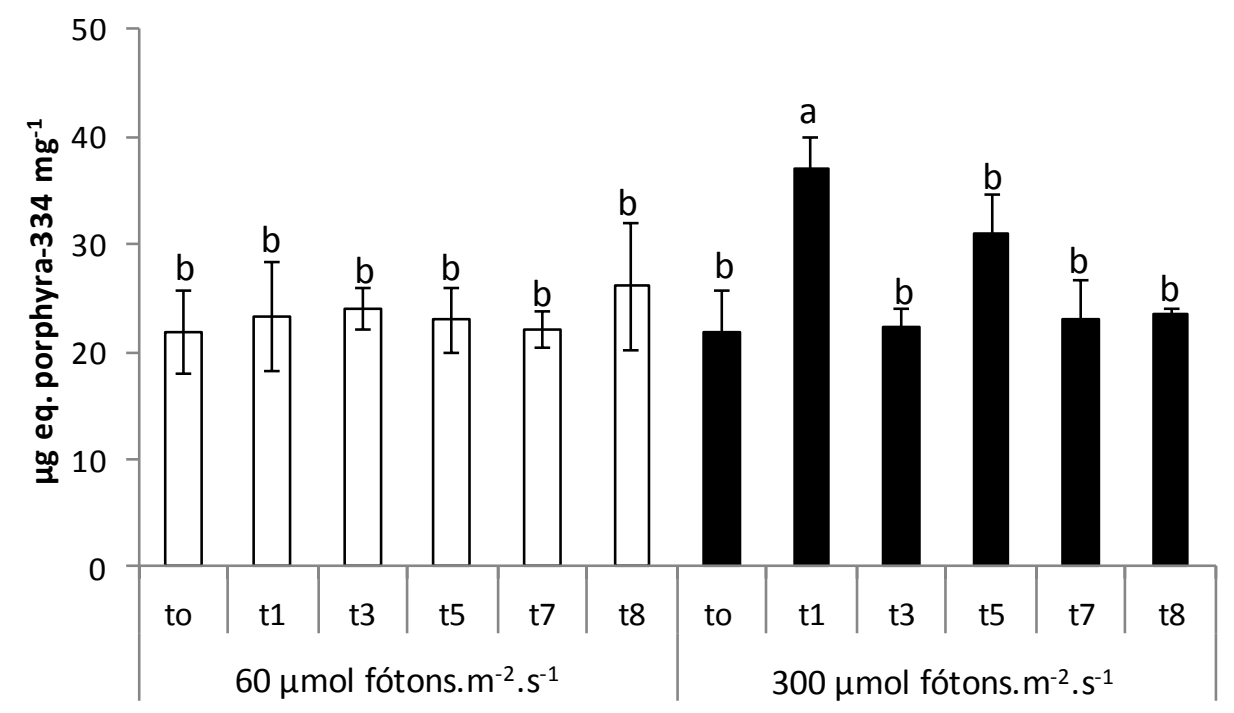

Figura 37. Quantificação da MAA chinorina em Pterocladiella capillacea ao longo do tempo (dias) nas irradiâncias de 60 e $300 \mu \mathrm{mol}$ fótons. $\mathrm{m}^{-2} . \mathrm{s}^{-1}$. Letras diferentes indicam diferença significativa $(\mathrm{p}<0,05)$ após a ANOVA e teste post-hoc de Newman-Keuls.

Lee \& Shiu (2009) compararam as defesas antioxidantes e conteúdo de MAAs de $P$. capillacea e Gelidium amansii (J.V. Lamouroux) J.V. Lamouroux frente à radiação UVB. Das duas espécies, $P$. capillacea foi mais resistente à exposição de radiação UVB, teve aumento do conteúdo de MAAs e ativação de defesas antioxidantes. Os MAAs chinorina, porphyra334 e palitinol foram encontrados em ambas as espécies, sendo porphyra-334 dominante em P. capillacea e chinorina em G. amansii. Segundo a classificação proposta por Hoyer et al. (2001): (1) algas sem capacidade para sintetizar MAAs; (2) algas com teor básico de MAAs que é ajustado em relação às mudanças na radiação ambiental; (3) algas com alto teor de MAAs independentemente das condições ambientais, Lee \& Shiu (2009) concluíram que $G$. amansii faria parte do grupo 1 e $P$. capillacea pertenceria ao grupo 2. Os resultados do presente estudo coincidem com a classificação de Lee \& Shiu (2009) para P. capillacea, espécie da qual possui um teor constitutivo de MAAs que é regulado pelas condições ambientais imperantes de radiação.

Frente a PAR, porphyra-334 e palitinol não foram observadas neste estudo. No entanto, Hoyer et al. (2001) afirmam que a capacidade para a síntese de MAAs em resposta a 
alterações ambientais é variável em algas. Na alga vermelha Porphyra umbilicalis Kützing a síntese de MAAs sob influência de PAR ou radiação UV não foi estimulada, no entanto, os níveis de MAAs mantiveram-se altos ao longo de todo experimento (Gröniger et al., 1999). Sinha et al. (2000) também não observaram indução no teor de MAAs em Gracilaria cornea J. Agardh frente PAR e UV, tais resultados diferem das respostas observadas em $P$. capillacea.

De forma análoga ao estímulo da síntese de MAAs pela radiação, Post \& Larkum (1993) observaram um aumento nos MAAs de Palmaria decipiens (Reinsch) R.W. Ricker e Prasiola crispa (Lightfoot) Kützing durante o verão (alta incidência de luz) e redução dos valores no inverno (baixa incidência de luz). Resultados similares foram obtidos por Aguilera et al. (2002) com as algas Palmaria palmata (Linnaeus) F. Weber \& D. Mohr e Devaleraea ramentacea (Linnaeus) Guiry. Estes resultados corroboram a alta dependência quantitativa do conteúdo de MAAs em relação à incidência de luminosidade.

A falta da manutenação do alto nível de chinorina em $P$. capillacea no t1 sob 300 $\mu$ mol fótons. $\mathrm{m}^{-2} . \mathrm{s}^{-1}$ (Fig. 37) pode ser devido à demanda de nitrogênio em virtude da elevada luminosidade. Visto que um aumento de irradiância poderia estimular uma maior demanda metabólica, além da síntese de MAAs para fotoproteção, o decréscimo de chinorina a partir do terceiro dia pode estar relacionado à sua degradação como reserva de nitrogênio. Os MAAs são substâncias nitrogenadas, podem atuar como reserva de nitrogênio frente a condições de estresse como, por exemplo, irradiância e possuem a capacidade de disponibilizá-los em períodos de carência de nutrientes (Miyamoto et al., 2014). Tal característica é análoga às ficobiliproteínas que também possuem atividade antioxidante (Andría et al., 1999; Tierney et al., 2010). Estudos sugerem que a limitação de nitrogênio pode levar a uma diminuição na produção quantitativa de MAAs (Karsten et al., 2007). Por outro lado, o teor de MAAs de algas vermelhas dos gêneros Porphyra C. Agardh, Grateloupia C. Agardh, Asparagopsis Montagne e Gracilaria Greville cultivadas em meios com maior disponibilidade de nitrogênio foi estimulado. Além disso, estudos que aliaram tratamentos com aumento de nutrientes e elevada radiação UV ou irradiância obtiveram melhores teores de MAAs (Korbee-Peinado et al., 2004; Korbee et al., 2005; Huovinen et al., 2006; Figueroa et al., 2008, Barufi et al., 2011). Dessa forma, esses estudos suportam a ideia de que o teor de chinorina de $P$. capillacea sob a irradiância de $300 \mu \mathrm{mol}$ fótons. $\mathrm{m}^{-2} . \mathrm{s}^{-1}$ não se 
manteve alto, possivelmente, em virtude do esgotamento de nutrientes devido à alta demanda metabólica imposta pelo aumento da irradiância.

Finalmente, os resultados deste estudo sobre a composição de MAAs na alga vermelha P. capillacea mostram a presença de um único MAA, chinorina. Esta descoberta pode ser melhor explorada para isolamento e futuras aplicações deste MAA. O aumento da intensidade PAR estimulou de forma transiente o mecanismo de síntese e fotopropteção de MAAs no tratamento t1-300 $\mu \mathrm{mol}$ fótons. $\mathrm{m}^{-2} \cdot \mathrm{s}^{-1}$, não se observando qualquer outra variação qualitativa ou quantitativa nos demais tratamentos. Apesar deste aumento sob $300 \mu \mathrm{mol}$ fótons. $\mathrm{m}^{-2} . \mathrm{s}^{-1} \mathrm{ser}$ passageiro, sugere-se aprofundar e realizar outros estudos que visem diferentes doses de PAR e outras condições como adição de nitrogênio e exposição a radiação UV.

\section{Referências bibliográficas}

Adams NL.; Shick JM. 1996. Mycosporine-like amino acids provide protection against ultraviolet radiation in eggs of the green sea urchin, Strongylocentrotus droebachiensis. J. Photochem. Photobiol. B. 64: 149-58.

Aguilera J.; Bischof K.; Karsten U.; Hanelt D.; Wiencke C. 2002. Seasonal variation in ecophysiological patterns in macroalgae from an Arctic fjord. II. Pigment accumulation and biochemical defence systems against high light stress. Mar. Biol. 140: 1087-1095.

Andria JR.; Vergara JJ.; Llorens LP. 1999. Biochemical responses and photosynthetic performance of Gracilaria sp. (Rhodophyta) from Cádiz, Spain, cultured under different inorganic carbon and nitrogen levels. Eur. J. Phycol. 34: 497-504.

Barre SL.; Roullier C.; Boustie J. 2014. Mycosporine-like amino acids (MAAs) in biological photosystems. In: Barre SL.; Kornprobst J. (eds) Outstanding Marine Molecules: Chemistry, Biology, Analysis. 499p.

Barufi JB.; Korbee N.; Oliveira MC.; Figueroa FL. 2011. Effects of N supply on the accumulation of photosynthetic pigments and photoprotectors in Gracilaria tenuistipitata (Rhodophyta) cultured under UV radiation. J. Appl. Phycol. 23: 457-466.

Carreto JI.; Carrignan MO. 2011. Mycosporine-like amino acids: relevant secondary metabolites. Chemica and ecological aspects. Mar. Drugs 9: 387-446.

Conde FR.; Churio MS.; Previtali CM. 2000. The photoprotector mechanism of mycosporinelike amino acids excited-state properties and photostability of porphyra-334 in aqueous solution. J. Photochem. Photobiol. B. 56: 139-44. 
Conde FR.; Churio MS.; Previtali CM. 2004. The deactivation pathways of the excited-states of the mycosporine-like amino acids shinorine and porphyra-334 in aqueous solution. Photochem. Photobiol. Sci. 3: 960-967.

Connan S.; Deslandes E.; Gall EA. 2007. Influence of daynight and tidal cycles on phenol content and antioxidant capacity in three temperate intertidal brown seaweeds. J. Exp. Mar. Biol. Ecol. 349: 359-369.

Chew YL.; Lim YY.; Omar M.; Khoo KS. 2008. Antioxidant activity of three edible seaweeds from two areas in South East Asia. Food Sci. Technol. 41: 1067-1072.

De La Coba F. 2007. Evaluación de la capacidad fotoprotectora y antioxidante de aminoácidos tipo micosporina. Aplicaciones biotecnológicas. Tese de Doutorado, Universidad de Málaga. Espanha. 294 p.

De La Coba F.; Aguilera J.; Figueroa F.; de Galvez M.; Herrera E. 2009. Antioxidant activity of mycosporine-like amino acids isolated from three red macroalgae and one marine lichen. J. Appl. Phycol. 21: 161-169.

Edwards P. 1970. Illustrated guide to the seaweeds and sea grasses in the vicinity of Porto Aransas, Texas. Contr. Mar. 15: 1-228.

Figueroa FL.; Bueno A.; Korbee N.; Santos R.; Mata L.; Schuenhoff A. 2008. Accumulation of mycosporine-like amino acids in Asparagopsis armata grown in tanks with fishpond effluents of gilthead sea bream Asparus aurata. J. World Aquacult. Soc. 39: 692-699.

Franklin LA.; Yakovleva I.; Karsten U.; Lüning K. 1999. Synthesis of mycosporine-like amino acids in Chondrus crispus (Florideophyceae) and the consequences for sensitivity to ultraviolet B radiation. J. Phycol. 35:682-93.

Franklin LA.; Kräbs G.; Kuhlenkamp R. 2001. Blue light and UV-A radiation control the synthesis of mycosproine-like amino acids in Chondrus crispus (Florideophyceae). $J$. Phycol. 37: 257-270.

Gravem AS.; Adams NL. 2012. Sex and microhabitat influence the uptake and allocation of mycosporine-like amino acids to tissues in the purple sea urchin, Strongylocentrotus purpuratus. Mar. Biol. 159: 2839-2852.

Gröniger A.; Hallier C.; Häder D. 1999. Influence of UV radiation ad visible light on Porphyra umbilicalis: Photoinhibition and MAA concentration. J. Appl. Phycol. 11: 437445 .

Hartmann A.; Becker K.; Karsten U.; Remias D.; Ganzera M. 2015. Analysis of mycosporinelike amino acids in selected algae and cyanobacteria by hydrophilic interaction liquid 
chromatography and a novel MAA from the red alga Catenella repens. Mar. Drugs 13: 62916305.

Hoyer K.; Karsten U.; Sawall T.; Wiencke C. 2001. Photoprotective substances in Antarctic macroalgae and their variation with respect to depth distribution, different tissues and developmental stages. Mar. Ecol. Prog. Ser. 211: 117-129.

Hoyer K.; Karsten U.; Wiencke C. 2002. Induction of sunscreen compounds in Antarctic macroalgae by different radiation conditions. Mar. Biol. 141: 619-627.

Huovinen P.; Gómez I. Figueroa FL.; Ulloa N.; Morales V.; Lovengreen CBM. 2004. Ultraviolet-absorbing mycosporine-like amino acids in red macroalgae from Chile. Bot. Mar. 47:21-29.

Huovinen P.; Matos J.; Pinto IS.; Figueroa FL. 2006. The role of ammonium in photoprotection against high irradiance in the red alga Grateloupia lanceola. Aquat. Bot. 24: 308-316.

Karsten U.; Franklin L.; Lüning K.; Wiencke C. 1998. Natural ultraviolet radiation and photosynthetically active radiation induce formation of mycosporine-like amino acids in the marine macroalga Chondrus crispus (Rhodophyta). Planta 205: 257-262.

Karsten U.; Lembcke S.; Schumann R. 2007. The effects of ultraviolet radiation on photosynthetic performance, growth and sunscreen compounds in aeroterrestrial biofilm algae isolated from building facades. Planta 225: 991-1000.

Korbee N. 2003. Fotorregulación y efecto del nitrógeno inorgánico en la acumulación de aminoácidos tipo micosporina en algas rojas. Tese de doutorado. Universidade de Málaga. Málaga. 279p.

Korbee-Peinado N.; Díaz RTA.; Figueroa FL.; Helbling EW. 2004. Ammonium and UV radiation stimulate the accumulation of mycosporine-like amino acids in Porphyra columbina (Rhodophyta) from Patagonia, Argentina. J. Phycol. 40: 248-259.

Korbee N.; Huovinen P.; Figueroa FL.; Aguilera J.; Karsten U. 2005. Availability of ammonium influences photosynthesis and the accumulation of mycosporine-like amino acids in two Porphyra species (Bangiales, Rhodophyta). Mar. Biol. 146: 645-654.

Korbee N.; Figueroa FL; Aguilera J. 2006. Acumulación de aminoácidos tipo micosporina (MAAs): biosíntesis, fotocontrol y funciones ecofisiológicas. Rev. Chil. Hist. Nat. 79:119-132. 
Kräbs G.; Bischof K.; Hanelt D.; Karsten U.; Wiencke C. 2002. Wavelength-dependent induction of UV absorbing mycosporine like amino acids in the red alga Chondrus crispus under natural solar radiation. Mar. Biol. 268: 69-82.

Lee TM.; CT Shiu. 2009. Implications of mycosporine-like amino acid and antioxidant defenses in UV-B radiation tolerance for the algae species Pterocladiella capillacea and Gelidium amansii. Mar. Environ. Res. 67: 8-16.

Lobban CS.; Harrison PJ. 2000. Seaweed ecology and physiology. $3^{\text {a }}$ Ed., Cambridge Univ.Press, Cambridge, 366p.

López Figueroa F.; Aguilera AJ.; De La Coba LF.; Korbee Peinado N. 2010. Composición para protección solar a base de extractos de algas y líquenes. In: Oficina espanhola de patentes e marcas. ES 2317741 B1. Data da concessão: 22.01.2010.

Marques LG. 2015. Aminoácidos tipo micosporina: novas metodologias e distribuição em macroalgas da costa brasileira. Tese de Doutorado. Universidade de São Paulo, São Paulo. 152p.

Miyamoto KT.; Komatsu M.; Ikeda H. 2014. Discovery of gene cluster for mycosporine-like amino acid biosynthesis from actinomycetales microorganisms and production of a novel mycosporine-like amino acid by heterologous expression. Appl. Environ. Microbiol. 80: 5028-5036.

Oren A.; Gunde-Cimerman N. 2007. Mycosporines and mycosporine-like amino acids: UV protectants or multipurpose secondary metabolites? Microbiol. Lett. 269: 1-10.

Post A.; Larkum AWD. 1993. UV-absorbing pigments, photosynthesis and UV exposure in Antarctica: comparison of terrestrial and marine algae. Aquat. Bot. 45: 231-243.

Plaza MA.; Cifuentes E.; Ibanez. 2008. In the search of new functional food ingredients from algae. Trends Food Sci. Tech. 19: 31-39.

Sampedro D. 2011. Computational exploration of natural sunscreens. Phys. Chem. Chem. Phys. 13: 5584-5586.

Singh SP.; Kumari RP.; Rastogi KL.; Singh R.; Sinha P. 2008. Mycosporine-like amino acids (MAAs): chemical structure, biosynthesis and significance as UV-absorbing/screening compounds. Indian J. Exp. Biol. 46: 7-17.

Sinha RP.; Klisch M.; Gröniger A.; Häder D-P. 2000. Mycosporine-like amino acids in the marine red alga Gracilaria cornea - effects of UV and heat. Environ. Exp. Bot. 43: 3343. 
Sinha RP.; Singh SP.; Häder DP. 2007. Database on mycosporines and mycosporine-like amino acids (MAAs) in fungi, cyanobacteria, macroalgae, phytoplankton and animals. $J$. Photochem. Photobiol. B. 89: 29-35.

Tierney MS.; Croft AK.; Hayes M. 2010. A review of antihypertensive and antioxidant activities in macroalgae. Bot. Mar. 53: 387-408.

Torres BP.; Chow F.; Ferreira M.; Santos DYAC. 2015. Effects of stressing high PAR on mycosporine-like amino acids in the red alga Gracilariopsis tenuifrons (Gracilariales, Rhodophyta). Planta Med. 1-8.

Torres BP.; Chow F.; Ferreira M.; Santos DYAC. 2016. Mycosporine-like amino acids from Gracilariopsis tenuifrons (Gracilariales, Rhodophyta) and its variation under high light. J. Appl. Phycol. 28:2035-2040.

Torres A.; Enk CD.; Hochberg M.; Srebnik M. 2006. Porphyra-334, a potential natural source for UVA protective sunscreens. Photochem. Photobiol. Sci. 5: 432-435.

Ursi S.; Plastino EM. 2001. Crescimento in vitro de linhagens de coloração vermelha e marrom-esverdeada clara de Gracilaria sp. (Gracilariales, Rhodophyta) em dois meios de cultura: análise de diferentes estádios reprodutivos. Rev. Bras. Bot. 24: 587-594.

Yoshiki MK.; Tsuge Y.; Tsuruta, T.; Yoshimura K.; Koganemaru T.; Sumi T.; Matsui KM. 2009. Production of new antioxidant compound from mycosporine-like amino acid, porphyra-334 by heat treatment. Food Chem. 113: 1127-1132.

Yuan YV.; Westcott ND.; Hu C.; Kitts DD. 2009. Mycosporine-like amino acid composition of the edible red alga, Palmaria palmata (dulse) harvested from the west and east coasts of Grand Manan Island, New Brunswick. Food Chem. 112: 321-328. 


\section{Discussão final}

Observando-se todos os resultados obtidos neste estudo para $P$. capillacea sob as intensidades de PAR de $60 \mu \mathrm{mol}$ fótons. $\mathrm{m}^{-2} \cdot \mathrm{s}^{-1}$ e $300 \mu \mathrm{mol}$ fótons. $\mathrm{m}^{-2} . \mathrm{s}^{-1}$, ao longo de oitos dias experimentais, a análise de componentes principais (PCA) nos permite explicar 72,11\% das tendências globais dos resultados do presente estudo (Fig. 38). A PCA formada pelos componentes 1 e 2 mostra a significância estatística dos valores, segundo as correlações de Pearson (ver Anexo V, Fig. AV 3 e Tabela AV 3).

As variações dos dados de clorofila, Folin, Fv/Fm e Y(PSII) estão diretamente relacionadas aos tratamentos para os quais seus respectivos vetores estão apontados, $\mathrm{t} 1 \mathrm{e}$ t8 de $300 \mu \mathrm{mol}$ fótons. $\mathrm{m}^{-2} \cdot \mathrm{s}^{-1}$. Esses parâmetros foram responsáveis pela maior variação entre todo o conjunto de dados para estes dois tempos.

A variação nos tratamentos $\mathrm{t} 3, \mathrm{t} 5$ e $\mathrm{t} 7 \mathrm{de} 300 \mu \mathrm{mol}$ fótons. $\mathrm{m}^{-2} \cdot \mathrm{s}^{-1}$ é explicada pelos

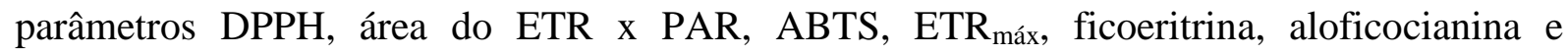
ficocianina.

Os resultados de Ik, MAAs, proteínas, FRAP, taxa de crescimento e Y(NO) explicam a maior variação dos dados nos tempos inciais (t0, t1, t3 e t5) de $60 \mu \mathrm{mol}$ fótons.m $\mathrm{m}^{-2} \cdot \mathrm{s}^{-1}$. Essa variação nos tratamentos é melhor explicada principalmente pelos parâmetros FRAP e Y(NO) em decorrência dos tamanhos maiores dos vetores. Os tempos t7 e t8 de $60 \mu \mathrm{mol}$ fótons. $\mathrm{m}^{-2}$.s ${ }^{1}$ foram mais influenciados pela atividade quelante de metais.

Os vetores mostram que as variáveis que causaram maior variação positiva de acordo com a PCA foram clorofila, Folin, Fv/Fm, Y(PSII), ficocianina, aloficocianina, ficoeritrina, ABTS e ETR máx.

Existe uma relação mais próxima e homogênea entre os tempos de $300 \mu$ mol fótons.m ${ }^{-}$ ${ }^{2} \cdot \mathrm{s}^{-1} \mathrm{e}$ duas relações podem ser distinguidas entre os tempos em $60 \mu \mathrm{mol}$ fótons. $\mathrm{m}^{-2} \cdot \mathrm{s}^{-1}$.

Em $60 \mu \mathrm{mol}$ fótons. $\mathrm{m}^{-2} . \mathrm{s}^{-1}$, os tempos iniciais se agrupam e na medida que aumenta o tempo ele vai se distanciando. A partir do quinto dia houve distanciamento. Isso pode ser explicado por certa limitação de nutriente. Esse resultado sugere que cinco dias seria o limite para $P$. capillacea manter sua fisiologia quase em ótimas condições sob as condições experimentais deste estudo. Dessa forma, se quisermos otimizar e aprimorar a aclimatação de $P$. capillacea em laboratório, cinco dias seriam suficientes. 


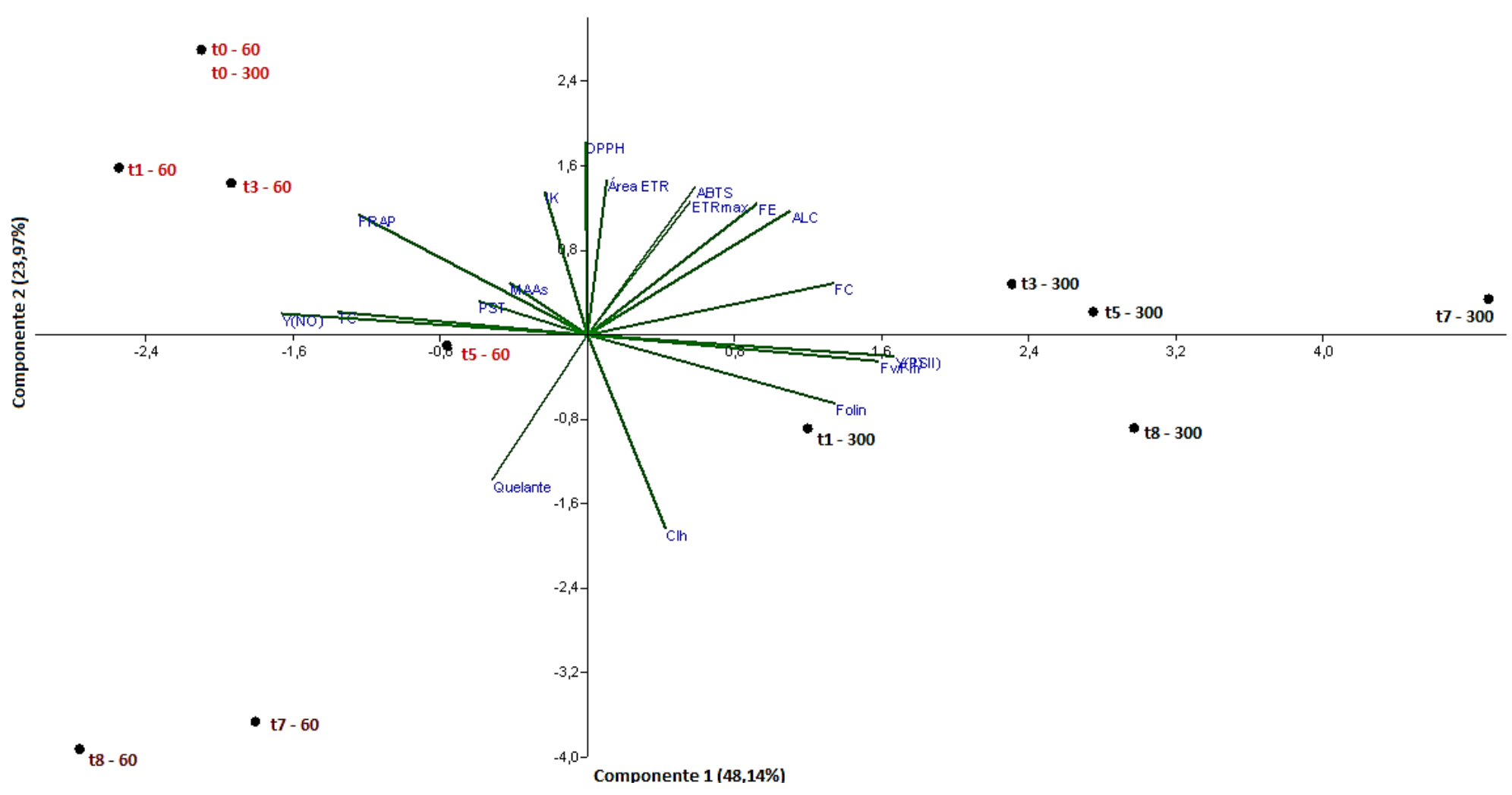

Figura 38. Ordenação biplot dos componentes 1 e 2 de $P$. capillacea durante o periodo experimental (t0, t1, t3, t5, t7 e t8) em função das variáveis métricas TC (taxa de crescimento), Clh (clorofila $a$ ), FE (ficoeritrina), FC (ficocianina), ALC (aloficocianina), PST (proteínas solúveis totais), Fv/Fm (rendimento quântico ótimo), Y(II) (rendimento quântico efetivo), Y(PSII) (dissipação fotoquímica), Y(NO) (dissipação não fotoquímica não regulada), Área ETR (área de ETR x PAR), Ik (saturação luminosa), ETR máx (taxa máxima de transporte de elétrons), DPPH, ABTS, Quelante, Folin, FRAP e MAAs (aminoácidos do tipo micosporinas) para irradiâncias de 60 e $300 \mu$ mol fótons.m ${ }^{-2} . \mathrm{s}^{-1}$. As cores vermelha, marrom e preta indicadas em cada tratamento representam os três agrupamentos. 
Adicionalmente, foram realizados agrupamentos de Cluster para os tratamentos (Fig. 39) e as variáveis (Fig. 40). O cluster é uma distância de valores, portanto não é uma análise estatística. Dessa forma, sua interpretação deve ser associada à PCA e às correlações de Pearson.

A Figura 39 apresenta um resumo do agrupamento dos tratamentos. É possível observer três principais grupos: (1) tratamentos iniciais de 60 e $300 \mu \mathrm{mol}$ fótons. $\mathrm{m}^{-2} . \mathrm{s}^{-1}$ (tempo 0) e tempos 1,3 e 5 de $60 \mu$ mol fótons. $\mathrm{m}^{-2} \cdot \mathrm{s}^{-1}$; (2) tempos finais 7 e 8 de $60 \mu \mathrm{mol}$ fótons. $\mathrm{m}^{-2} \cdot \mathrm{s}^{-1}$; (3) relação dos tempos $1,3,5,7$ e 8 de $300 \mu \mathrm{mol}$ fótons. $\mathrm{m}^{-2} \cdot \mathrm{s}^{-1}$. Esses três grandes grupos foram também evidenciados na PCA (Fig. 32).

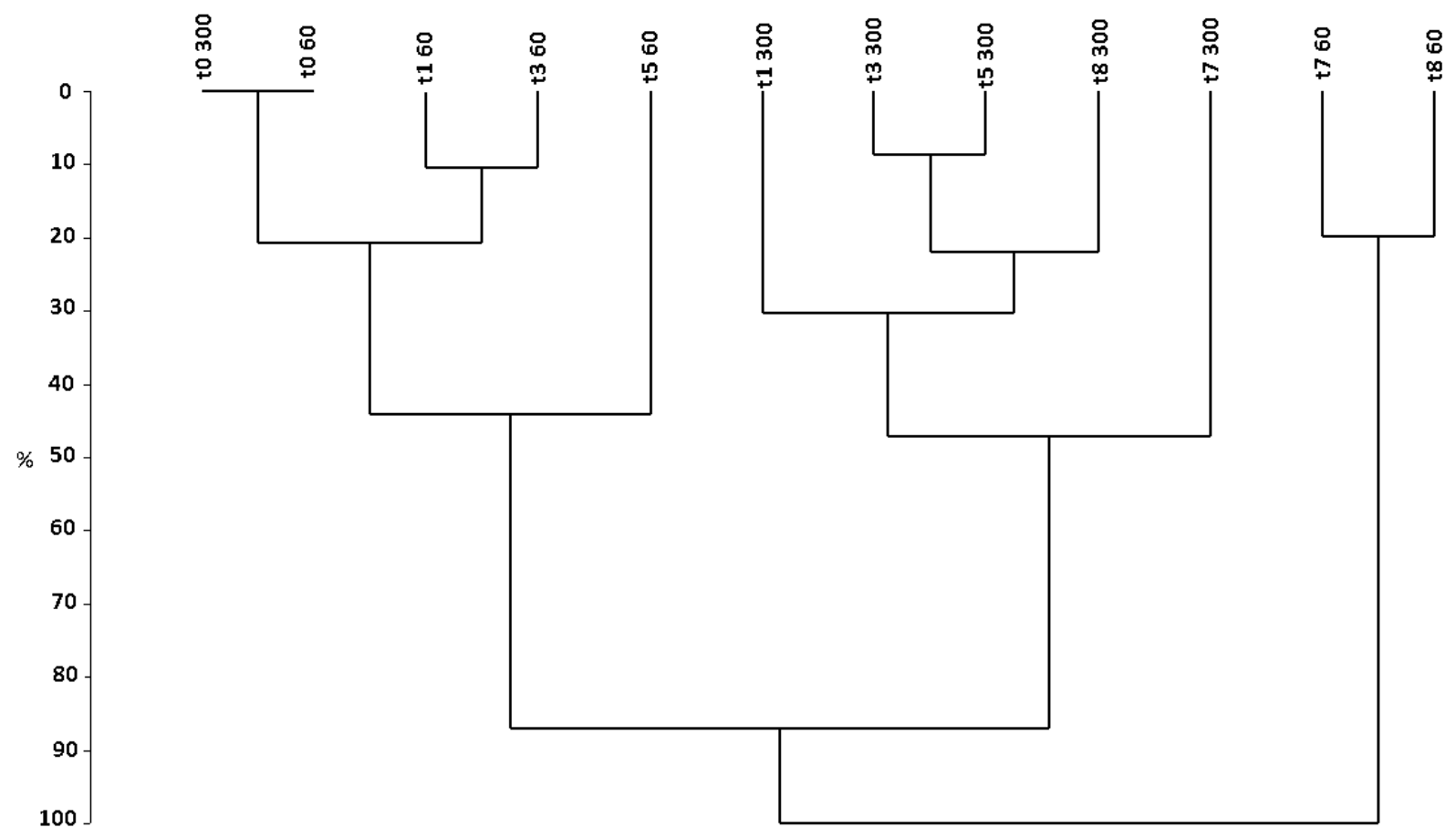

Figura 39. Dendrograma obtido da análise de agrupamento hierárquico utilizando os tratamentos de Pterocladiella capillacea ao longo do tempo (t0, t1, t3, t5, t7 e t8) para irradiâncias de 60 e $300 \mu \mathrm{mol}$ fótons. $\mathrm{m}^{-2} \cdot \mathrm{s}^{-1}$.

Observa-se, na Figura 40, que as variáveis fotossintetizantes Y(II) e Y(PSII) mostram o mesmo agrupamento por não possuírem porcentagem de distância. Essas variáveis, junto com $\mathrm{Fv} / \mathrm{Fm}$, foram o grupo mais próximo, pois a porcentagem de distância entre eles foi pequena. As variáveis são agrupadas, por ordem de semelhança, ou seja, Clorofila $a$ e quelantes formaram o grupo mais divergente do dendograma, que se mantiveram distante dos 
demais grupos formados, pelo fato dessas variáveis possuírem pouca semelhança em relação às outras.

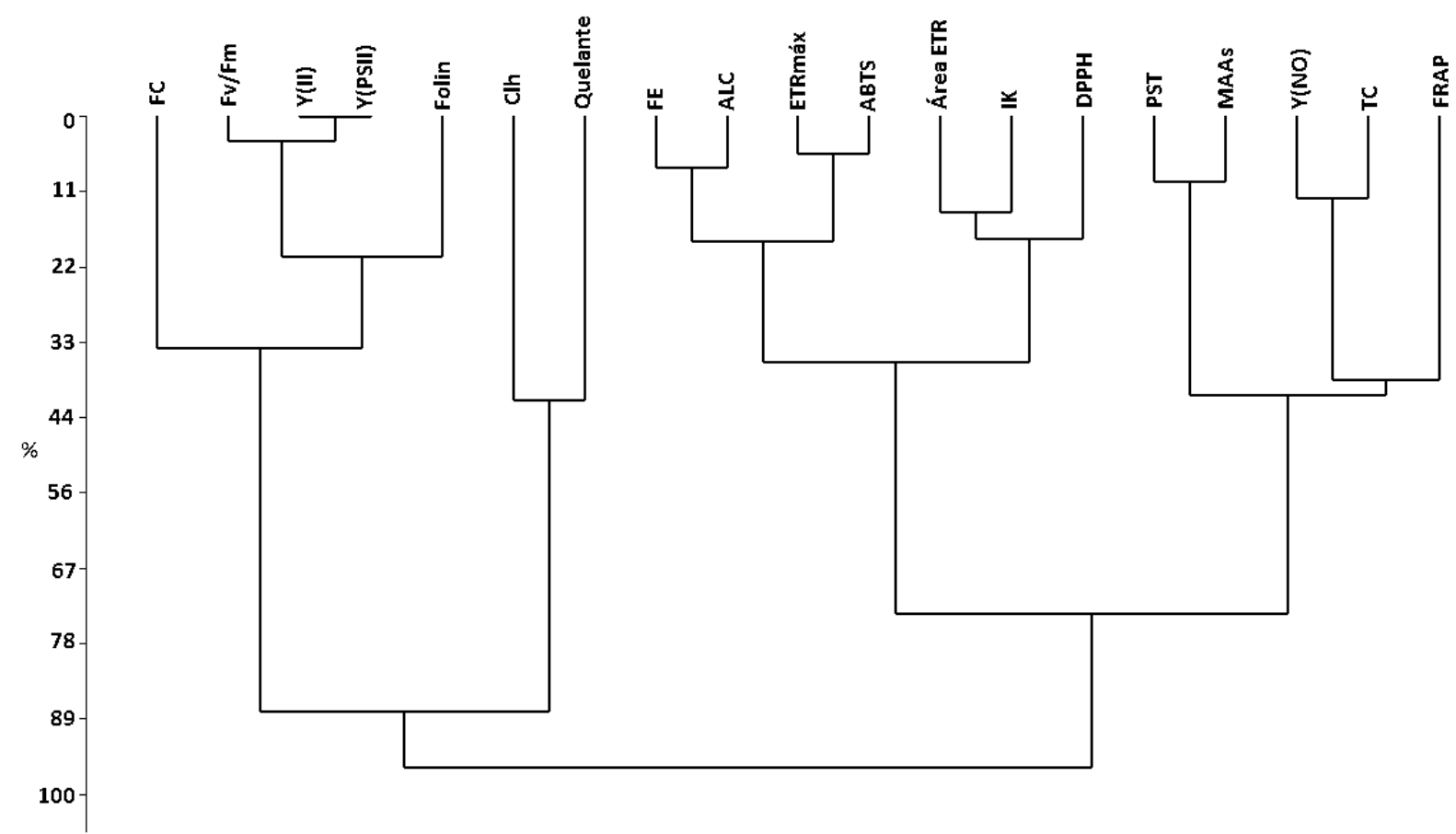

Figura 40. Dendrograma obtido da análise de agrupamento hierárquico utilizando as métricas resultantes de Pterocladiella capillacea avaliadas nos diferentes tempos e irradiâncias.

As análises mostram que a PCA e os agrupamentos de cluster reforçam os resultados apresentados nos capítulos, $300 \mu \mathrm{mol}$ fótons. $\mathrm{m}^{-2} \cdot \mathrm{s}^{-1}$ apresenta um efeito completamente diferente de $60 \mu \mathrm{mol}$ fótons. $\mathrm{m}^{-2} \cdot \mathrm{s}^{-1}$. Visando a resposta metabólica global de $P$. capillacea, esses dados mostram claramente que do ponto de vista fisiológico e metabólico $P$. capillacea responde de forma significativamente diferente para 60 e $300 \mu \mathrm{mol}$ fótons. $\mathrm{m}^{-2} . \mathrm{s}^{-1}$. Ao integrar todos os parâmetros estudados, é possível observar que há alteração durante o período experimental e é possível inferir que haverá mudanças nas variáveis analisadas no futuro. Dessa forma, se avaliarmos todos os parâmetros influenciados por $300 \mu \mathrm{mol}$ fótons. $\mathrm{m}^{-2} \cdot \mathrm{s}^{-1}$, é possível imaginar que estes serão alterados pelas mudanças climáticas, em longo prazo. Por exemplo, se as condições de $60 \mu \mathrm{mol}$ fótons. $\mathrm{m}^{-2} \cdot \mathrm{s}^{-1}$ se mantiverem, $P$. capillacea irá crescer bem, no entanto esse comportamento será influenciado pelo aumento de irradiância previsto. 
Uma vez que os resultados do presente estudo demonstraram que $300 \mu$ mol fótons.m ${ }^{-}$ ${ }^{2}$.s ${ }^{-1}$ afetou $70 \%$ do metabolismo de $P$. capillacea em uma semana. Sob o ponto de vista global, em longo prazo, haverá alteração, pois matematicamente é visto que existe influência da irradiância.

O conjunto de resultados aqui apresentados contribui para conhecimento da biologia de algas vermelhas submetidas a condições de estresse luminoso, dessa forma, o principal objetivo dessa pesquisa foi atingido.

A hipótese (a) foi rejeitada. Pois nas condições testadas não houve diminuição da fotossíntese e houve pouca variação no teor de pigmentos fotossintetizantes na presença de alta intensidade de PAR. Dessa forma, $300 \mu \mathrm{mol}$ fótons. $\mathrm{m}^{-2} \cdot \mathrm{s}^{-1}$ não foi uma irradiância estressante nesses parâmetros. A hipótese (b) foi corroborada. Pois o aumento da intensidade de PAR estimulou os mecanismos de fotoproteção de potencial antioxidante em três dos cinco ensaios testados e estimulou a síntese de MAAs. 


\section{Conclusão geral}

- O aumento da irradiância ocasionou dimuição em alguns parâmetros fotossintetizantes de Pterocladiella capillacea, demonstrando um processo de fotoaclimatação. Adicionalmente, $300 \mu \mathrm{mol}$ fótons. $\mathrm{m}^{-2} \cdot \mathrm{s}^{-1}$ representa uma intensidade excessiva de luz, na qual $P$. capillacea dissipa eficientemente como calor sem gasto de energia.

- Pterocladiella capillacea demonstra bom conteúdo de proteínas solúveis totais que quando cultivada são acumulados ao longo do tempo, independente da irradiância.

- Os resultados indicam que $P$. capillacea possui atividade antioxidante, o que permite sugerir aprofundamentos nos estudos e aproveitamento como fonte de bioprodutos funcionais.

- Pterocladiella capillacea apresentou como único MAA chinorina, o que pode ser considerada fonte de grande interesse comercial. Além disso, os resultados mostraram a possibilidade de induzir chinorina sob cultivo em $300 \mu \mathrm{mol}$ fótons. $\mathrm{m}^{-2} \cdot \mathrm{s}^{-1}$.

- Pterocladiella capillacea mostrou sensibilidade diferencial a $300 \mu \mathrm{mol}$ fótons. $\mathrm{m}^{-2} \cdot \mathrm{s}^{-1}$, evidenciado pelas diversas respostas analisadas, manifestando mecanismos de aclimatação e tolerância via fotossíntese, pigmentos, atividade antioxidante e síntese de chinorina.

- Finalmente, os resultados aqui apresentados contribuem de forma significativa no conhecimento sobre a biologia de algas vermelhas submetidas a estímulos luminosos, permitindo assim uma melhor compreensão das respostas fisiológicas e composição química de $P$. capillacea sob influência de alta intensidade de PAR. Assim como também no conhecimento da potencialidade de P. capillacea como fonte de bioprodutos funcionais como proteínas, antioxidantes e MAAs. 


\section{Considerações finais}

Os serviços ecossistêmicos, imprescindíveis para manutenção da vida na Terra, resultam do valor inerente de cada espécie, seu conjunto, bem como de interações entre espécies e destas com o meio físico-químico. Enfoques em estudos de serviços ecossistêmicos e de paisagem devem ser utilizados para aprofundar o conhecimento sobre funcionamento de ecossistemas, permitindo desta forma uma melhor valoração de serviços ambientais. Esses aspectos tornam-se importantes para inserir a temática das dimensões humanas da conservação da biodiversidade e para o avanço da ecologia da conservação, bem como entender os impactos das mudanças climáticas no nosso entorno ambiental e estrutural de comunidades costeiras.

Assim, pesquisas que integrem diferentes abordagens fisiológicas e de composição química são de grande valor, possibilitando uma melhor compreensão das respostas metabólicas dos organismos, focado aqui no modelo de $P$. capillacea do litoral do município de Marataízes, sul do estado do Espírito Santo. Local no qual pouquíssimos estudos fisiológicos têm sido realizados. Pontanto, trabalhos que visem complementar aspectos ecológicos e fisiológicos podem fornecer imporantes subsídios para o manejo e a explotação sustentável da espécie.

Finalmente, estudos que aprofundem na influência da radiação solar, incluindo ou não a radiação UV, no ambiente natural e em laboratório são recomendados, a fim de poder compilar maiores informações sobre as respostas das algas às condições imperantes no ambiente e à possibilidade de alteração frente às mudanças ambientais e às mudanças climáticas globais. 


\begin{abstract}
Anexos
A seguir, serão apresentados alguns anexos que tem por objetivo descrever com maior detalhe alguns testes preliminares realizados para definir procedimentos e metodologias. Neste item, incluo cinco anexos intitulados:

I. Medidas de fluorescência da clorofila $a$ do PSII;

II. Curvas padrões de BSA para quantificação de proteínas solúveis totais;

III. Potencial antioxidante de extratos metanólicos de $P$. capillacea;

IV. Extração de MAAs;

V. Análise de componentes principais e correlações de Pearson.
\end{abstract}

\title{
ANEXO I - Medidas de fluorescência da clorofila $a$ do PSII
}

A fim de avaliar e estabelecer alguns parâmetros para medidas de fluorescência in vivo da clorofila do PSII em Pterocladiella capillacea, foram feitos testes de: (a) medidas da intensidade de luz actínica em distâncias de 0 e $2 \mathrm{~mm}$ da fibra ótica, (b) níveis crescentes de pulso de saturação sobre o rendimento quântico efetivo (Y(II)) da clorofila $a$ do PSII, (c) tempos de aclimatação ao escuro e duração do pulso de luz actínica sobre a taxa maxima de transporte de elétrons e (d) curvas ETR X PAR no claro e escuro com diferentes tempos de duração.

Os testes foram realizados com $P$. capillacea coletada na Praia de Cibratel (34¹3'19”S; 47¹5'28,11”O), no município de Itanhaém, SP. Esse material foi mantido em cultivo nas mesmas condições de aclimatação descritas no item de Material e métodos gerais.

\section{Irradiância versus distância da fibra óptica}

Uma das formas de regular o nível de Ft (fluorescência transiente inicial) nas medidas de fluorescência para alcançar os valores basais de 200 a 400 de calibração da sensibilidade do aparelho é regular a distância da fibra óptica. Assim, o questionamento foi saber se a distância da fibra óptica poderia afetar de maneira significativa a incidência de luz. Dessa forma, realizaram-se medidas da intensidade de luz com a fibra posicionada diretamente no sensor e com a fibra posicionada a $2 \mathrm{~mm}$ do sensor. Para tal, foram medidas as intensidades 
de diferentes níveis de luz actínica com um sensor plano Li-COR modelo L1-250 (EUA), conectado a um medidor de quanta Li-COR modelo L1-1000 (EUA).

A Figura AI-1A monstra que a incidência de luz é menor na medida em que aumentase a distância da fibra ótica em relação ao sensor. Mesmo as medidas sendo diferentes a uma distância de $2 \mathrm{~mm}$, assumimos que sob as intensidades em que são avaliados a fluorescência da clorofila $a$, estas variações não chegam a alterar a resposta de fotossíntese. Dessa forma, sugere-se que pequenas alterações na distância da fibra não seriam capazes de alterar as respostas fotossintetizantes de algas vermelhas.

\section{Níveis de pulso de saturação}

$\mathrm{Na}$ literatura, existem diversos valores de pulsos de saturação na avaliação da fotossíntese mediante a fluorescência in vivo de clorofila $a$ do PSII. Os valores variam de 3.000 a $10.000 \mu \mathrm{mol}$ fótons. $\mathrm{m}^{-2} \cdot \mathrm{s}^{-1}$. Assim, surge o questionamento de qual nível de pulso de saturação seria mais apropriado para $P$. capillacea?

O fluorímetro PAM-2500 (Walz, Alemanha) possui níveis de intensidade de pulso de saturação de 1 até 20, sendo avaliados pulsos nos níveis de 6 ao 16 que correspondem a intensidades PAR de 107, 185, 300, 455, 751 e $900 \mu \mathrm{mol}$ fótons.m $\mathrm{m}^{-2} \mathrm{~s}^{-1}$.

Na Figura AI-1B observa-se que não houve diferença significativa no rendimento quântico efetivo (Y(II)) entre os níveis de pulso de saturação. Dessa forma, qualquer uma das intensidades de nível de pulso de saturação poderia ser utilizada em $P$. capillacea. Este tipo de avaliação faz-se necessária, pois além de resguardar a vida-média da fibra ótica do equipamento, é necessário garantir que todos os centros de reação tenham sido saturados, de tal forma que todos se tornem reduzidos. Nestas condições estão indisponíveis, temporariamente, para fazer fotossíntese.

Após constatar que o Y(II) não varia em relação ao pulso de saturação aplicado, para P. capillacea optou-se por utilizar o nível de saturação 10, a fim de garantir a saturação dos sistemas de reação dos fotossistemas. Este mesmo nível de intensidade de saturação tem sido utilizado para outras espécies de algas vermelhas como Gracilariopsis, Pyropia e Bostrychia, algas verdes como Ulva, Chaetomorpha e Chaetomorpha e a alga parda Sargassum. 

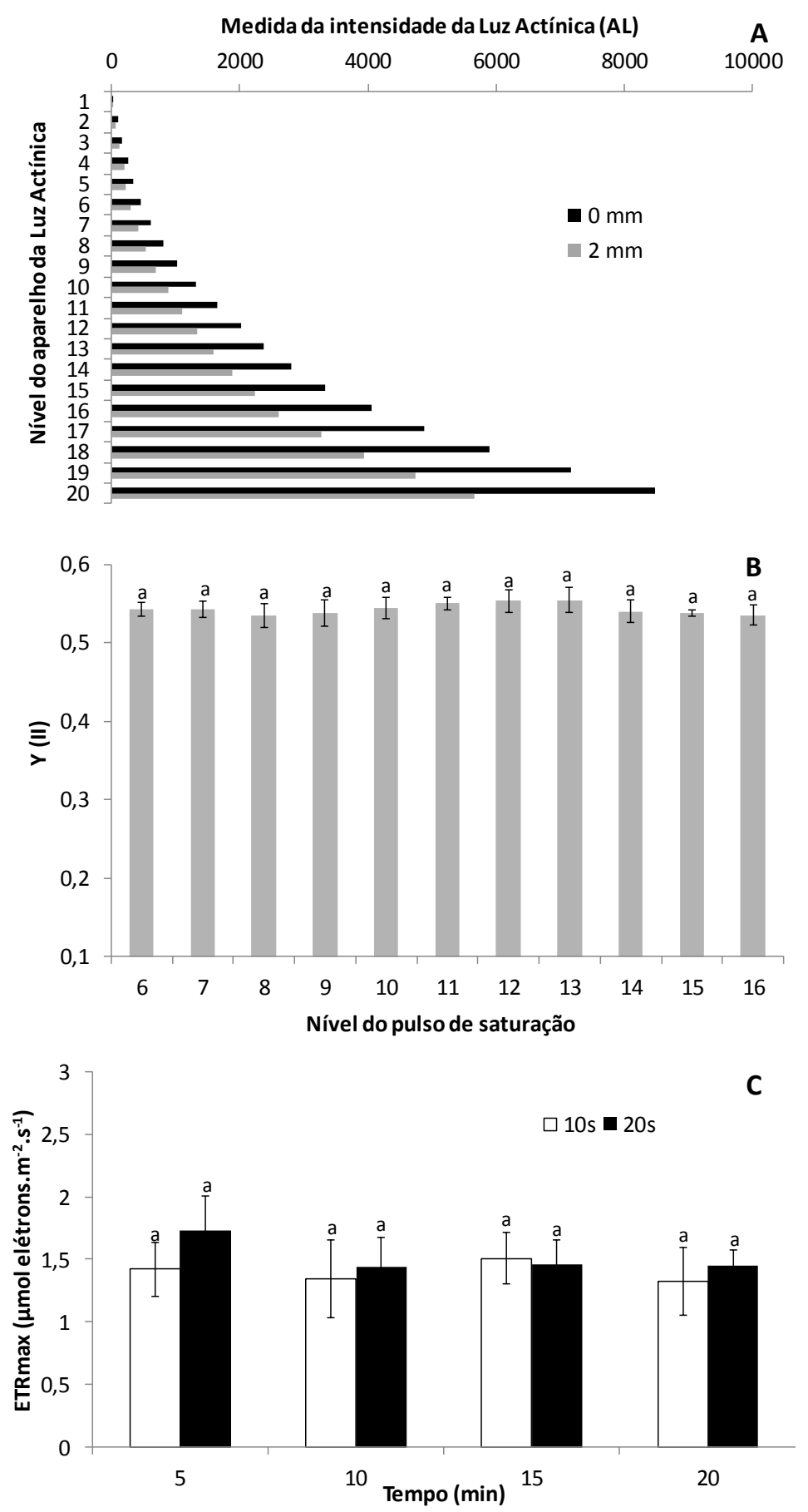

Anexo I - Figura 1. (A) Medida da intensidade de luz actínica em distâncias de $0 \mathrm{~mm}$ e $2 \mathrm{~mm}$ da fibra ótica do PAM-2500. (B) Rendimento quântico efetivo (Y(II)) da clorofila $a$ do PSII de Pterocladiella capillacea sob níveis crescentes de pulso de saturação do fluorímetro PAM2500. (C) Taxa máxima de transporte de elétrons $\left(\mathrm{ETR}_{\text {máx }}\right)$ de Pterocladiella capillacea estimada em diferentes tempo de adaptação ao escuro e dois exposições de pulsos de luz actínica (10 e $20 \mathrm{seg}$ ). Letras diferentes indicam diferença significativa ( $p<0,05$,) após a ANOVA e teste post-hoc de Newman-Keuls. 


\section{Tempo de adaptação ao escuro e pulsos de luz actínica da curva ETR-PAR}

A aclimatação ao escuro é uma condição importante para possibilitar que todos os centros de reação estejam disponíveis para absorver o máximo possível de luz. Assim, outro questionamento foi quanto tempo de adaptação ao escuro seria mais indicado para $P$. capillacea? Na literaura, existem estudos que utilizamde 5 a 30 minutos (Koblizek et al., 1999; Antal et al., 2003; Zemri et al., 2012). O tempo de adaptação ao escuro é importante devido ao fato estar freqüentemente associada com a re-oxidação do aceptor de elétrons do PSII.

$\mathrm{Na}$ adaptação ao escuro, várias enzimas são inativadas para prevenir reações de desperdício de energia. Tais enzimas incluem exemplos de Rubisco (Streusand \& Portis, 1987); outras quatro enzimas dependentes de tiorredoxina: d-fructose 1,6-bisfosfatase, phosphoribulokinase, sedoeptulose-1,7-bisfosfatase (Buchanan, 1984; Scheibe, 1990) e ATP sintase (Stumpp et al., 1999). Estas enzimas são ativas na luz, durante uma transição leve a escuro, eles gradualmente se tornam inativos novamente. A inativação de enzimas varia dependendo da espécie, algumas necessitam de $15 \mathrm{~min}$ para a inativação completa (Papageorgiou \& Govindjee, 2011).

Na maioria dos estudos de fluorescência, muitos não estão interessados nos processos mencionados acima, e, nesse caso, o melhor é fazer o tempo de adaptação ao escuro suficientemente longo para permitir que todas as quinonas estejam esvaziadas (Schansker et al., 2006; 2008).

Além disso, o fluorímetro PAM-2500 possibilita que a curva de ETR-PAR possa ser realizada com pulso de luz actínica de 10 ou 20 seg. O tempo do pulso é importante de estabelecer, pois é esperado que a fluorescência aumentasse durante o período de indução fotossintetizante e, após este período, a emissão da fluorescência será reduzida. Esta redução na emissão da fluorescência é explicada, pois somente a partir de um determinado tempo de iluminação do material, as reações de fixação do carbono tornam-se ativas (Campostrini, 1997).

Para $P$. capillacea foram testados quatro tempos de adaptação ao escuro: 5, 10, 15 e 20 min, sendo mensurado o ETR. Além disso, foram realizadas curvas de ETR-PAR sob dois tempos de pulsos de luz actínica, 10 e 20 seg.

A Figura AI-3C monstra que não houve diferença significativa na taxa máxima de transporte de elétrons $\left(\mathrm{ETR}_{\text {máx }}\right)$ entre os quatro tempos de adaptação ao escuro, nem entre os 
tempos testados de 10 ou 20 seg de pulso de luz actínica. Dessa forma, optou-se por utilizar 15 min de adaptação ao escuro para garantir a redução de todas as quinonas, e 10 seg de pulso de luz actínica a fim de otimizar o tempo de análises.

\section{Curvas ETR X PAR no claro e escuro com diferentes tempos de duração}

Foram realizadas curvas de ETR x PAR em diferentes tempos de escuro $(5,10,15$ e 20 minutos) e com tempos de duração da curva testados com duração de 10 e 20 segundos (Fig. AI-2). Nas curvas com duração de 10s não houve muita variação entre os quatro tempos testados, a área abaixo da curva variou de 263,81 a 300,80 (Fig. AI-2A). Nas curvas com duração de 20s houve variação no tempo de 10 minutos, a área abaixo da curva alcançou o pico de 513,53. Os tempos de 5, 15 e 20 minutos obtiveram curvas de fotossíntese semelhantes (Fig. AI-2B). A Figura AI-3 mostra as curvas de ETR x PAR com duração de 10 e 20 segundos no claro, é possível observar que não houve variação entre as duas durações testadas, ambas apresentaram respostas semelhantes.
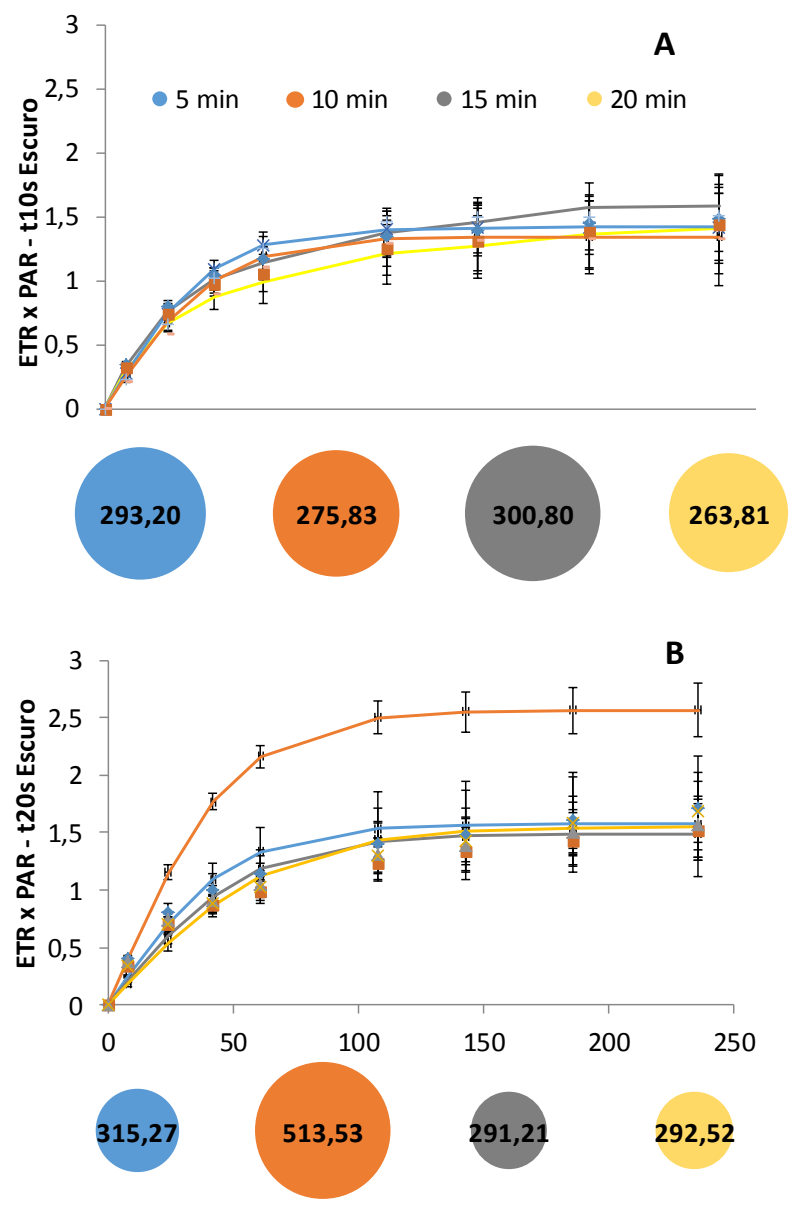

Anexo I - Figura 2. Curva ETR x PAR no escuro com tempos de (A) 10 segundos e (B) 20 segundos. Os gráficos de bola representam área embaixo das curvas. 


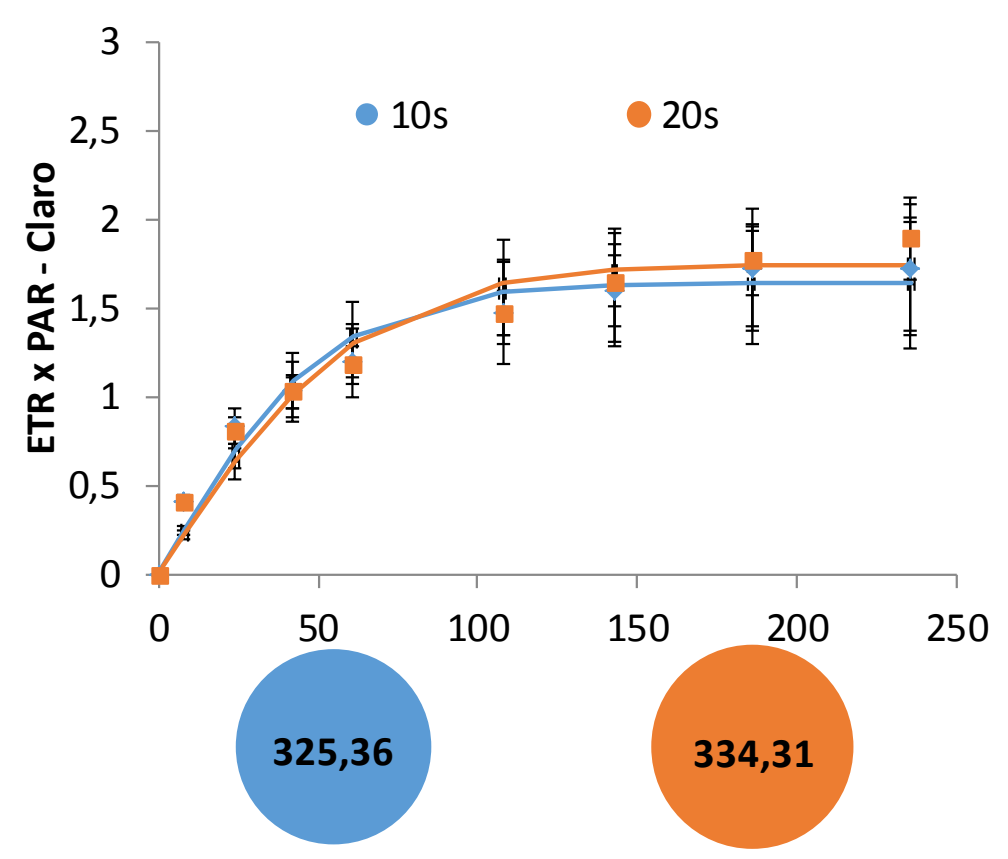

Anexo I - Figura 3. Curva ETR x PAR no claro com tempos de 10 e 20 segundos. Os gráficos de bola representam área embaixo das curvas.

As Tabelas AI-1-6 sintetizam os resultados de significância estatística de ANOVA e teste post hoc de Newman-Keuls para todos os parâmetros apresentados no Capítulo I. 
Anexo I - Tabela 1. Tabelas de significância de ANOVA e teste post hoc de Newman-Keuls para (A) ETR máx $_{\text {, }}$ (B) Alfa e (C) Fv/Fm.

\begin{tabular}{|c|c|c|c|c|c|c|c|c|c|c|c|c|c|}
\hline \multicolumn{14}{|l|}{ A - ETR máx $_{\text {m }}$} \\
\hline ANOVA & $\begin{array}{l}\text { Soma dos } \\
\text { quadrados }\end{array}$ & $\begin{array}{l}\text { Grau de } \\
\text { liberdade }\end{array}$ & $\begin{array}{c}\text { Média } \\
\text { quadrada }\end{array}$ & $\mathbf{F}$ & p & & & & & & & & \\
\hline Intercepto & 376,3380 & 1 & 376,3380 & 3569,340 & 0,000000 & & & & & & & & \\
\hline Tempo & 11,0425 & 5 & 2,2085 & 20,946 & 0,000000 & & & & & & & & \\
\hline Irradiância & 6,5783 & 1 & 6,5783 & 62,391 & 0,000000 & & & & & & & & \\
\hline Tempo*Irradiância & 6,1190 & 5 & 1,2238 & 11,607 & 0,000004 & & & & & & & & \\
\hline Erro & 2,9522 & 28 & 0,1054 & & & & & & & & & & \\
\hline \multicolumn{14}{|l|}{ Newman-Keuls } \\
\hline Tempo & Irradiância & to -60 & to -300 & $\mathrm{t} 1-60$ & $t 1-300$ & t3 -60 & $\mathrm{t} 3-\mathbf{3 0 0}$ & t5 - 60 & t5 -300 & t7 - 60 & $t 7-300$ & t8 - 60 & t8 -300 \\
\hline to & 60 & & 0,729075 & 0,000143 & 0,971438 & 0,978541 & 0,594843 & 0,033562 & 0,832357 & 0,000148 & 0,273202 & 0,001404 & 0,039466 \\
\hline to & 300 & 0,729075 & & 0,000189 & 0,582088 & 0,408740 & 0,524350 & 0,005516 & 0,594777 & 0,000137 & 0,093092 & 0,000305 & 0,007609 \\
\hline $\mathrm{t} 1$ & 60 & 0,000143 & 0,000189 & & 0,000149 & 0,000163 & 0,000147 & 0,001088 & 0,000135 & 0,058174 & 0,000195 & 0,012908 & 0,001183 \\
\hline $\mathrm{t} 1$ & 300 & 0,971438 & 0,582088 & 0,000149 & & 0,872142 & 0,834825 & 0,040290 & 0,926382 & 0,000163 & 0,348852 & 0,001623 & 0,050059 \\
\hline $\mathrm{t} 3$ & 60 & 0,978541 & 0,408740 & 0,000163 & 0,872142 & & 0,881421 & 0,034717 & 0,934906 & 0,000189 & 0,343030 & 0,001334 & 0,045114 \\
\hline t3 & 300 & 0,594843 & 0,524350 & 0,000147 & 0,834825 & 0,881421 & & 0,080482 & 0,967693 & 0,000142 & 0,401856 & 0,003981 & 0,085043 \\
\hline t5 & 60 & 0,033562 & 0,005516 & 0,001088 & 0,040290 & 0,034717 & 0,080482 & & 0,059283 & 0,000170 & 0,362588 & 0,169500 & 0,833535 \\
\hline t5 & 300 & 0,832357 & 0,594777 & 0,000135 & 0,926382 & 0,934906 & 0,967693 & 0,059283 & & 0,000145 & 0,215139 & 0,003113 & 0,053858 \\
\hline 7 & 60 & 0,000148 & 0,000137 & 0,058174 & 0,000163 & 0,000189 & 0,000142 & 0,000170 & 0,000145 & & 0,000133 & 0,000327 & 0,000139 \\
\hline $\mathrm{t} 7$ & 300 & 0,273202 & 0,093092 & 0,000195 & 0,348852 & 0,343030 & 0,401856 & 0,362588 & 0,215139 & 0,000133 & & 0,043418 & 0,251157 \\
\hline t8 & 60 & 0,001404 & 0,000305 & 0,012908 & 0,001623 & 0,001334 & 0,003981 & 0,169500 & 0,003113 & 0,000327 & 0,043418 & & 0,252977 \\
\hline t8 & 300 & 0,039466 & 0,007609 & 0,001183 & 0,050059 & 0,045114 & 0,085043 & 0,833535 & 0,053858 & 0,000139 & 0,251157 & 0,252977 & \\
\hline \multicolumn{14}{|l|}{ B - Alfa } \\
\hline ANOVA & $\begin{array}{l}\text { Soma dos } \\
\text { quadrados }\end{array}$ & $\begin{array}{l}\text { Grau de } \\
\text { liberdade }\end{array}$ & $\begin{array}{c}\text { Média } \\
\text { quadrada }\end{array}$ & $\mathbf{F}$ & p & & & & & & & & \\
\hline Intercepto & 224976,3 & 1 & 224976,3 & 1713,739 & 0,000000 & & & & & & & & \\
\hline Tempo & 17783,9 & 5 & 3556,8 & 27,093 & 0,000000 & & & & & & & & \\
\hline Irradiância & 678,5 & 1 & 678,5 & 5,168 & 0,028739 & & & & & & & & \\
\hline Tempo*Irradiância & 2518,7 & 5 & 503,7 & 3,837 & 0,006524 & & & & & & & & \\
\hline Erro & 4988,6 & 38 & 131,3 & & & & & & & & & & \\
\hline \multicolumn{14}{|l|}{ Newman-Keuls } \\
\hline Tempo & Irradiância & to - 60 & to -300 & $t 1-60$ & $t 1-300$ & $t 3-60$ & $t 3-300$ & t5 - 60 & t5 - 300 & t7 -60 & t7 -300 & t8 -60 & t8 -300 \\
\hline to & 60 & & 0,670116 & 0,667081 & 0,578072 & 0,703336 & 0,532428 & 0,000542 & 0,622972 & 0,000124 & 0,000179 & 0,702187 & 0,741253 \\
\hline to & 300 & 0,670116 & & 0,798152 & 0,671368 & 0,849251 & 0,746261 & 0,001351 & 0,617438 & 0,000176 & 0,000162 & 0,861807 & 0,896995 \\
\hline $\mathrm{t} 1$ & 60 & 0,667081 & 0,798152 & & 0,954516 & 0,923313 & 0,957720 & 0,007909 & 0,912144 & 0,000130 & 0,000264 & 0,972236 & 0,993221 \\
\hline $\mathrm{t} 1$ & 300 & 0,578072 & 0,671368 & 0,954516 & & 0,987003 & 0,974620 & 0,009023 & 0,727223 & 0,000137 & 0,000265 & 0,991950 & 0,997507 \\
\hline t3 & 60 & 0,703336 & 0,849251 & 0,923313 & 0,987003 & & 0,933988 & 0,007236 & 0,957200 & 0,000127 & 0,000260 & 0,897835 & 0,984094 \\
\hline t3 & 300 & 0,532428 & 0,746261 & 0,957720 & 0,974620 & 0,933988 & & 0,004492 & 0,924851 & 0,000166 & 0,000284 & 0,889183 & 0,676323 \\
\hline t5 & 60 & 0,000542 & 0,001351 & 0,007909 & 0,009023 & 0,007236 & 0,004492 & & 0,004380 & 0,001117 & 0,147523 & 0,006532 & 0,003935 \\
\hline t5 & 300 & 0,622972 & 0,617438 & 0,912144 & 0,727223 & 0,957200 & 0,924851 & 0,004380 & & 0,000151 & 0,000188 & 0,968319 & 0,983484 \\
\hline t7 & 60 & 0,000124 & 0,000176 & 0,000130 & 0,000137 & 0,000127 & 0,000166 & 0,001117 & 0,000151 & & 0,019423 & 0,000139 & 0,000127 \\
\hline t7 & 300 & 0,000179 & 0,000162 & 0,000264 & 0,000265 & 0,000260 & 0,000284 & 0,147523 & 0,000188 & 0,019423 & & 0,000266 & 0,000245 \\
\hline t8 & 60 & 0,702187 & 0,861807 & 0,972236 & 0,991950 & 0,897835 & 0,889183 & 0,006532 & 0,968319 & 0,000139 & 0,000266 & & 0,967114 \\
\hline t8 & 300 & 0,741253 & 0,896995 & 0,993221 & 0,997507 & 0,984094 & 0,676323 & 0,003935 & 0,983484 & 0,000127 & 0,000245 & 0,967114 & \\
\hline \multicolumn{14}{|l|}{$\mathrm{C}-\mathrm{Fv} / \mathrm{Fm}$} \\
\hline ANOVA & $\begin{array}{l}\text { Soma dos } \\
\text { quadrados }\end{array}$ & $\begin{array}{l}\text { Grau de } \\
\text { liberdade }\end{array}$ & $\begin{array}{l}\text { Média } \\
\text { quadrada }\end{array}$ & $\mathbf{F}$ & $p$ & & & & & & & & \\
\hline Intercepto & 14,49977 & 1 & 14,49977 & 7407,202 & 0,000000 & & & & & & & & \\
\hline Tempo & 0,06455 & 5 & 0,01291 & 6,595 & 0,000054 & & & & & & & & \\
\hline Irradiância & 0,10792 & 1 & 0,10792 & 55,130 & 0,000000 & & & & & & & & \\
\hline Tempo*Irradiância & 0,06802 & 5 & 0,01360 & 6,950 & 0,000032 & & & & & & & & \\
\hline Erro & 0,12332 & 63 & 0,00196 & & & & & & & & & & \\
\hline \multicolumn{14}{|l|}{ Newman-Keuls } \\
\hline Tempo & Irradiância & to -60 & to -300 & $t 1-60$ & $\mathrm{t} 1-300$ & $t 3-60$ & $t 3-300$ & t5 - 60 & t5 - 300 & t7 -60 & t7 -300 & t8 -60 & t8 -300 \\
\hline to & 60 & & 0,239115 & 0,560403 & 0,000417 & 0,962339 & 0,234238 & 0,916767 & 0,008237 & 0,984837 & 0,000162 & 0,945588 & 0,007991 \\
\hline to & 300 & 0,239115 & & 0,298514 & 0,000174 & 0,258871 & 0,006002 & 0,312553 & 0,000180 & 0,361289 & 0,000121 & 0,300934 & 0,000200 \\
\hline $\mathrm{t} 1$ & 60 & 0,560403 & 0,298514 & & 0,000201 & 0,808016 & 0,086069 & 0,769927 & 0,001715 & 0,880781 & 0,000173 & 0,802514 & 0,001591 \\
\hline $\mathrm{t} 1$ & 300 & 0,000417 & 0,000174 & 0,000201 & & 0,001029 & 0,057295 & 0,000450 & 0,495807 & 0,000577 & 0,190788 & 0,000678 & 0,301188 \\
\hline t3 & 60 & 0,962339 & 0,258871 & 0,808016 & 0,001029 & & 0,121123 & 0,942385 & 0,010194 & 0,753101 & 0,000140 & 0,934810 & 0,014543 \\
\hline t3 & 300 & 0,234238 & 0,006002 & 0,086069 & 0,057295 & 0,121123 & & 0,218155 & 0,152876 & 0,150679 & 0,002218 & 0,229466 & 0,279203 \\
\hline t5 & 60 & 0,916767 & 0,312553 & 0,769927 & 0,000450 & 0,942385 & 0,218155 & & 0,008423 & 0,966753 & 0,000142 & 0,831368 & 0,008532 \\
\hline t5 & 300 & 0,008237 & 0,000180 & 0,001715 & 0,495807 & 0,010194 & 0,152876 & 0,008423 & & 0,007721 & 0,076656 & 0,011021 & 0,926003 \\
\hline t7 & 60 & 0,984837 & 0,361289 & 0,880781 & 0,000577 & 0,753101 & 0,150679 & 0,966753 & 0,007721 & & 0,000134 & 0,973053 & 0,009272 \\
\hline t7 & 300 & 0,000162 & 0,000121 & 0,000173 & 0,190788 & 0,000140 & 0,002218 & 0,000142 & 0,076656 & 0,000134 & & 0,000132 & 0,054348 \\
\hline t8 & 60 & 0,945588 & 0,300934 & 0,802514 & 0,000678 & 0,934810 & 0,229466 & 0,831368 & 0,011021 & 0,973053 & 0,000132 & & 0,012008 \\
\hline t8 & 300 & 0,007991 & 0,000200 & 0,001591 & 0,301188 & 0,014543 & 0,279203 & 0,008532 & 0,926003 & 0,009272 & 0,054348 & 0,012008 & \\
\hline
\end{tabular}


Anexo I - Tabela 2. Tabelas de significância de ANOVA e teste post hoc de Newman-Keuls para (A) Ik, (B) Absorptância e (C) Y(II).

\begin{tabular}{|c|c|c|c|c|c|c|c|c|c|c|c|c|c|}
\hline \multicolumn{14}{|l|}{ A - IK } \\
\hline ANOVA & $\begin{array}{l}\text { Soma dos } \\
\text { quadrados }\end{array}$ & $\begin{array}{l}\text { Grau de } \\
\text { liberdade }\end{array}$ & $\begin{array}{c}\text { Média } \\
\text { quadrada }\end{array}$ & $\mathbf{F}$ & p & & & & & & & & \\
\hline Intercepto & 164466,4 & 1 & 164466,4 & 2844,541 & 0,000000 & & & & & & & & \\
\hline Tempo & 14411,7 & 5 & 2882,3 & 49,852 & 0,000000 & & & & & & & & \\
\hline Irradiância & 1057,9 & 1 & 1057,9 & 18,297 & 0,000261 & & & & & & & & \\
\hline Tempo*Irradiância & 2953,9 & 5 & 590,8 & 10,218 & 0,000024 & & & & & & & & \\
\hline Erro & 1387,6 & 24 & 57,8 & & & & & & & & & & \\
\hline \multicolumn{14}{|l|}{ Newman-Keuls } \\
\hline Tempo & Irradiância & to -60 & to -300 & $t 1-60$ & $t 1-300$ & $\mathrm{t} 3-60$ & t3 -300 & t5 -60 & t5 - 300 & t7 -60 & t7 -300 & t8 -60 & t8 - 300 \\
\hline to & 60 & & 0,326616 & 0,467606 & 0,200462 & 0,040133 & 0,096638 & 0,000168 & 0,582907 & 0,000143 & 0,000194 & 0,028471 & 0,102609 \\
\hline to & 300 & 0,326616 & & 0,848484 & 0,610977 & 0,236494 & 0,411026 & 0,000163 & 0,957812 & 0,000194 & 0,000170 & 0,185669 & 0,447057 \\
\hline t1 & 60 & 0,467606 & 0,848484 & & 0,558033 & 0,265963 & 0,408102 & 0,000151 & 0,931552 & 0,000168 & 0,000163 & 0,217921 & 0,469977 \\
\hline $\mathrm{t} 1$ & 300 & 0,200462 & 0,610977 & 0,558033 & & 0,647065 & 0,595629 & 0,000178 & 0,348922 & 0,000147 & 0,000179 & 0,622675 & 0,806521 \\
\hline t3 & 60 & 0,040133 & 0,236494 & 0,265963 & 0,647065 & & 0,800599 & 0,000326 & 0,239648 & 0,000126 & 0,000406 & 0,811479 & 0,588329 \\
\hline t3 & 300 & 0,096638 & 0,411026 & 0,408102 & 0,595629 & 0,800599 & & 0,000247 & 0,311679 & 0,000144 & 0,000250 & 0,815267 & 0,929360 \\
\hline t5 & 60 & 0,000168 & 0,000163 & 0,000151 & 0,000178 & 0,000326 & 0,000247 & & 0,000148 & 0,000707 & 0,863488 & 0,000277 & 0,000253 \\
\hline t5 & 300 & 0,582907 & 0,957812 & 0,931552 & 0,348922 & 0,239648 & 0,311679 & 0,000148 & & 0,000160 & 0,000150 & 0,205203 & 0,406581 \\
\hline t7 & 60 & 0,000143 & 0,000194 & 0,000168 & 0,000147 & 0,000126 & 0,000144 & 0,000707 & 0,000160 & & 0,000463 & 0,000161 & 0,000138 \\
\hline t7 & 300 & 0,000194 & 0,000170 & 0,000163 & 0,000179 & 0,000406 & 0,000250 & 0,863488 & 0,000150 & 0,000463 & & 0,000363 & 0,000224 \\
\hline t8 & 60 & 0,028471 & 0,185669 & 0,217921 & 0,622675 & 0,811479 & 0,815267 & 0,000277 & 0,205203 & 0,000161 & 0,000363 & & 0,712626 \\
\hline t8 & 300 & 0,102609 & 0,447057 & 0,469977 & 0,806521 & 0,588329 & 0,929360 & 0,000253 & 0,406581 & 0,000138 & 0,000224 & 0,712626 & \\
\hline \multicolumn{14}{|l|}{ B - Absorptância } \\
\hline ANOVA & $\begin{array}{l}\text { Soma dos } \\
\text { quadrados }\end{array}$ & $\begin{array}{l}\text { Grau de } \\
\text { liberdade }\end{array}$ & $\begin{array}{c}\text { Média } \\
\text { quadrada }\end{array}$ & $\mathbf{F}$ & p & & & & & & & & \\
\hline Intercepto & 38,66427 & 1 & 38,66427 & 6151,54 & 0 & & & & & & & & \\
\hline Tempo & 0,14591 & 5 & 0,02918 & 4,643 & 0,001157 & & & & & & & & \\
\hline Irradiância & 0,02162 & 1 & 0,02162 & 3,44 & 0,068393 & & & & & & & & \\
\hline Tempo*Irradiância & 0,03165 & 5 & 0,00633 & 1,007 & 0,421097 & & & & & & & & \\
\hline Erro & 0,38969 & 62 & 0,00629 & & & & & & & & & & \\
\hline \multicolumn{14}{|l|}{ Newman-Keuls } \\
\hline Tempo & Irradiância & to -60 & to -300 & t1 - 60 & $\mathrm{t} 1-300$ & t3 -60 & $t 3-300$ & t5 - 60 & t5 -300 & t7 - 60 & t7 -300 & t8 - 60 & t8 -300 \\
\hline to & 60 & & 0,985444 & 0,7623 & 0,557236 & 0,569233 & 0,872103 & 0,794964 & 0,946219 & 0,540402 & 0,938447 & 0,093679 & 0,841653 \\
\hline to & 300 & 0,985444 & & 0,89822 & 0,880803 & 0,399489 & 0,543322 & 0,864192 & 0,97544 & 0,520535 & 0,960567 & 0,072053 & 0,864641 \\
\hline $\mathrm{t} 1$ & 60 & 0,762304 & 0,898218 & & 0,910213 & 0,282348 & 0,64254 & 0,830492 & 0,844899 & 0,755043 & 0,862699 & 0,238405 & 0,943918 \\
\hline $\mathrm{t} 1$ & 300 & 0,557236 & 0,880803 & $3 \quad 0,91021$ & & 0,28965 & 0,633969 & 0,942403 & 0,800991 & 0,80357 & 0,782956 & 0,252089 & 0,971824 \\
\hline t3 & 60 & 0,569233 & 0,399489 & 0,28235 & 0,28965 & & 0,492438 & 0,220984 & 0,545727 & 0,049619 & 0,520365 & 0,002176 & 0,205609 \\
\hline t3 & 300 & 0,872103 & 0,543322 & 0,64254 & 0,633969 & 0,492438 & & 0,570615 & 0,797414 & 0,215567 & 0,814296 & 0,015844 & 0,557881 \\
\hline t5 & 60 & 0,794964 & 0,864192 & 0,83049 & 0,942403 & 0,220984 & 0,570615 & & 0,817572 & 0,719094 & 0,85603 & 0,250334 & 0,913724 \\
\hline t5 & 300 & 0,946219 & 0,97544 & 0,8449 & 0,800991 & 0,545727 & 0,797414 & 0,817572 & & 0,482523 & 0,811636 & 0,065568 & 0,828039 \\
\hline t7 & 60 & 0,540402 & 0,520535 & 0,75504 & 0,80357 & 0,049619 & 0,215567 & 0,719094 & 0,482523 & & 0,571214 & 0,277092 & 0,507282 \\
\hline t7 & 300 & 0,938447 & 0,960567 & 0,8627 & 0,782956 & 0,520365 & 0,814296 & 0,85603 & 0,811636 & 0,571214 & & 0,096964 & 0,877392 \\
\hline t8 & 60 & 0,093679 & 0,072053 & $3 \quad 0,23841$ & 0,252089 & 0,002176 & 0,015844 & 0,250334 & 0,065568 & 0,277092 & 0,096964 & & 0,190306 \\
\hline t8 & 300 & 0,841653 & 0,864641 & 0,94392 & 0,971824 & 0,205609 & 0,557881 & 0,913724 & 0,828039 & 0,507282 & 0,877392 & 0,190306 & \\
\hline \multicolumn{14}{|l|}{$C-Y(I I)$} \\
\hline ANOVA & $\begin{array}{l}\text { Soma dos } \\
\text { quadrados }\end{array}$ & $\begin{array}{l}\text { Grau de } \\
\text { liberdade }\end{array}$ & $\begin{array}{c}\text { Média } \\
\text { quadrada }\end{array}$ & $\mathbf{F}$ & p & & & & & & & & \\
\hline Intercept & 16,81806 & 1 & 16,81806 & 10965,37 & 0,000000 & & & & & & & & \\
\hline Tempo & 0,03183 & 5 & 0,00637 & 4,15 & 0,002535 & & & & & & & & \\
\hline Irradiância & 0,09674 & 1 & 0,09674 & 63,07 & 0,000000 & & & & & & & & \\
\hline Tempo*Irradiância & 0,02895 & 5 & 0,00579 & 3,77 & 0,004715 & & & & & & & & \\
\hline Error & 0,09663 & 63 & 0,00153 & & & & & & & & & & \\
\hline \multicolumn{14}{|l|}{ Newman-Keuls } \\
\hline Tempo & Irradiância & to -60 & to -300 & $\mathrm{t} 1-60$ & $\mathrm{t} 1-300$ & $\mathrm{t} 3-60$ & $\mathrm{t} 3-300$ & t5 - 60 & t5 - 300 & $\mathrm{t} 7-60$ & t7 -300 & t8 - 60 & t8 -300 \\
\hline to & 60 & & 0,861108 & 0,650673 & 0,172136 & 0,800314 & 0,021082 & 0,952747 & 0,105518 & 0,985247 & 0,000142 & 0,970345 & 0,005358 \\
\hline to & 300 & 0,861108 & & 0,713439 & 0,169819 & 0,813860 & 0,025809 & 0,935070 & 0,115058 & 0,979452 & 0,000131 & 0,953828 & 0,007131 \\
\hline $\mathrm{t} 1$ & 60 & 0,650673 & 0,713439 & & 0,038541 & 0,982632 & 0,002279 & 0,719746 & 0,017664 & 0,388804 & 0,000173 & 0,795050 & 0,000543 \\
\hline $\mathrm{t} 1$ & 300 & 0,172136 & 0,169819 & 0,038541 & & 0,045954 & 0,513068 & 0,087947 & 0,713334 & 0,218594 & 0,003078 & 0,114640 & 0,357319 \\
\hline t3 & 60 & 0,800314 & 0,813860 & 0,982632 & 0,045954 & & 0,002602 & 0,781454 & 0,020492 & 0,648612 & 0,000121 & 0,861547 & 0,000599 \\
\hline t3 & 300 & 0,021082 & 0,025809 & 0,002279 & 0,513068 & 0,002602 & & 0,030095 & 0,463142 & 0,025498 & 0,024564 & 0,021427 & 0,587780 \\
\hline t5 & 60 & 0,952747 & 0,935070 & 0,719746 & 0,087947 & 0,781454 & 0,030095 & & 0,097412 & 0,982351 & 0,000138 & 0,771989 & 0,010483 \\
\hline t5 & 300 & 0,105518 & 0,115058 & 0,017664 & 0,713334 & 0,020492 & 0,463142 & 0,097412 & & 0,129637 & 0,005879 & 0,088665 & 0,409797 \\
\hline t7 & 60 & 0,985247 & 0,979452 & 0,388804 & 0,218594 & 0,648612 & 0,025498 & 0,982351 & 0,129637 & & 0,000163 & 0,994346 & 0,006291 \\
\hline t7 & 300 & 0,000142 & 0,000131 & 0,000173 & 0,003078 & 0,000121 & 0,024564 & 0,000138 & 0,005879 & 0,000163 & & 0,000134 & 0,035914 \\
\hline t8 & 60 & 0,970345 & 0,953828 & 3,795050 & 0,114640 & 0,861547 & 0,021427 & 0,771989 & 0,088665 & 0,994346 & 0,000134 & & 0,006330 \\
\hline t8 & 300 & 0,005358 & 0,007131 & 0,000543 & 0,357319 & 0,000599 & 0,587780 & 0,010483 & 0,409797 & 0,006291 & 0,035914 & 0,006330 & \\
\hline
\end{tabular}


Anexo I - Tabela 3. Tabelas de significância de ANOVA e teste post hoc de Newman-Keuls para (A) Y(NO) e (B) Y(PSII).

\begin{tabular}{|c|c|c|c|c|c|c|c|c|c|c|c|c|c|}
\hline \multicolumn{14}{|l|}{$A-Y(N O)$} \\
\hline ANOVA & $\begin{array}{l}\text { Soma dos } \\
\text { quadrados }\end{array}$ & $\begin{array}{l}\text { Grau de } \\
\text { liberdade }\end{array}$ & $\begin{array}{c}\text { Média } \\
\text { quadrada }\end{array}$ & $\mathbf{F}$ & $\mathbf{p}$ & & & & & & & & \\
\hline Intercepto & 18,76325 & 1 & 18,76325 & 12205,98 & 0 & & & & & & & & \\
\hline Tempo & 0,03184 & 5 & 0,00637 & 4,14 & 0,00257 & & & & & & & & \\
\hline Irradiância & 0,09622 & 1 & 0,09622 & 62,6 & 0 & & & & & & & & \\
\hline Tempo*Irradiância & 0,02894 & 5 & 0,00579 & 3,76 & 0,004793 & & & & & & & & \\
\hline Erro & 0,09684 & 63 & 0,00154 & & & & & & & & & & \\
\hline \multicolumn{14}{|l|}{ Newman-Keuls } \\
\hline Tempo & Irradiância & to -60 & to $-\mathbf{3 0 0}$ & $\mathrm{t} 1-60$ & $t 1-300$ & $\mathrm{t} 3-60$ & t3 -300 & t5 - 60 & t5 - 300 & $\mathrm{t} 7-60$ & t7 - 300 & t8 -60 & t8 - 300 \\
\hline to & 60 & & 0,866 & 0,647796 & 0,177743 & 0,800134 & 0,022139 & 0,954034 & 0,110631 & 0,984583 & 0,000142 & 0,971509 & 0,005552 \\
\hline to & 300 & 0,866 & & 0,714423 & 0,17313 & 0,816849 & 0,026607 & 0,934671 & 0,118815 & 0,980568 & 0,000131 & 0,952606 & 0,007246 \\
\hline $\mathrm{t} 1$ & 60 & 0,647796 & 0,714423 & & 0,039743 & 0,986015 & 0,002374 & 0,720071 & 0,018519 & 0,386766 & 0,000173 & 0,795108 & 0,000553 \\
\hline $\mathrm{t} 1$ & 300 & 0,177743 & 0,17313 & 0,039743 & & 0,0479 & 0,513818 & 0,089947 & 0,716947 & 0,225026 & 0,003083 & 0,11737 & 0,354805 \\
\hline t3 & 60 & 0,800134 & 0,816849 & 0,986015 & 0,0479 & & 0,002745 & 0,784094 & 0,021743 & 0,648924 & 0,000121 & 0,863453 & 0,000617 \\
\hline t3 & 300 & 0,022139 & 0,026607 & 0,002374 & 0,513818 & 0,002745 & & 0,031089 & 0,460958 & 0,026704 & 0,024522 & 0,022185 & 0,583737 \\
\hline $\mathrm{t} 5$ & 60 & 0,954034 & 0,934671 & 0,720071 & 0,089947 & 0,784094 & 0,031089 & & 0,100742 & 0,982877 & 0,000139 & 0,772318 & 0,010678 \\
\hline $\mathrm{t} 5$ & 300 & 0,110631 & 0,118815 & 0,018519 & 0,716947 & 0,021743 & 0,460958 & 0,100742 & & 0,135501 & 0,005805 & 0,091948 & 0,404467 \\
\hline $\mathrm{t} 7$ & 60 & 0,984583 & 0,980568 & 0,386766 & 0,225026 & 0,648924 & 0,026704 & 0,982877 & 0,135501 & & 0,000163 & 0,994605 & 0,006512 \\
\hline $\mathrm{t} 7$ & 300 & 0,000142 & 0,000131 & 0,000173 & 0,003083 & 0,000121 & 0,024522 & 0,000139 & 0,005805 & 0,000163 & & 0,000134 & 0,036353 \\
\hline t8 & 60 & 0,971509 & 0,952606 & 0,795108 & 0,11737 & 0,863453 & 0,022185 & 0,772318 & 0,091948 & 0,994605 & 0,000134 & & 0,006461 \\
\hline t8 & 300 & 0,005552 & 0,007246 & 0,000553 & 0,354805 & 0,000617 & 0,583737 & 0,010678 & 0,404467 & 0,006512 & 0,036353 & 0,006461 & \\
\hline \multicolumn{14}{|l|}{ B - Y(PSII) } \\
\hline ANOVA & $\begin{array}{l}\text { Soma dos } \\
\text { quadrados }\end{array}$ & $\begin{array}{l}\text { Grau de } \\
\text { liberdade }\end{array}$ & $\begin{array}{c}\text { Média } \\
\text { quadrada }\end{array}$ & $F$ & p & & & & & & & & \\
\hline Intercepto & 16,81889 & 1 & 16,81889 & 10941,12 & 0 & & & & & & & & \\
\hline Tempo & 0,03184 & 5 & 0,00637 & 4,14 & 0,00257 & & & & & & & & \\
\hline Irradiância & 0,09622 & 1 & 0,09622 & 62,6 & 0 & & & & & & & & \\
\hline Tempo*Irradiância & 0,02894 & 5 & 0,00579 & 3,76 & 0,004793 & & & & & & & & \\
\hline Erro & 0,09684 & 63 & 0,00154 & & & & & & & & & & \\
\hline \multicolumn{14}{|l|}{ Newman-Keuls } \\
\hline Tempo & Irradiância & to -60 & to $-\mathbf{3 0 0}$ & $t 1-60$ & $t 1-300$ & $\mathrm{t} 3-60$ & t3 $-\mathbf{3 0 0}$ & t5 - 60 & t5 -300 & t7 - 60 & t7 - 300 & t8 -60 & t8 - 300 \\
\hline to & 60 & & 0,866 & 0,647796 & 0,177743 & 0,800134 & 0,022139 & 0,954034 & 0,110631 & 0,984583 & 0,000142 & 0,971509 & 0,005552 \\
\hline to & 300 & 0,866 & & 0,714423 & 0,17313 & 0,816849 & 0,026607 & 0,934671 & 0,118815 & 0,980568 & 0,000131 & 0,952606 & 0,007246 \\
\hline $\mathrm{t} 1$ & 60 & 0,647796 & 0,714423 & & 0,039743 & 0,986015 & 0,002374 & 0,720071 & 0,018519 & 0,386766 & 0,000173 & 0,795108 & 0,000553 \\
\hline $\mathrm{t} 1$ & 300 & 0,177743 & 0,17313 & 0,039743 & & 0,0479 & 0,513818 & 0,089947 & 0,716947 & 0,225026 & 0,003083 & 0,11737 & 0,354805 \\
\hline t3 & 60 & 0,800134 & 0,816849 & 0,986015 & 0,0479 & & 0,002745 & 0,784094 & 0,021743 & 0,648924 & 0,000121 & 0,863453 & 0,000617 \\
\hline $\mathrm{t} 3$ & 300 & 0,022139 & 0,026607 & 0,002374 & 0,513818 & 0,002745 & & 0,031089 & 0,460958 & 0,026704 & 0,024522 & 0,022185 & 0,583737 \\
\hline $\mathrm{t} 5$ & 60 & 0,954034 & 0,934671 & 0,720071 & 0,089947 & 0,784094 & 0,031089 & & 0,100742 & 0,982877 & 0,000139 & 0,772318 & 0,010678 \\
\hline $\mathrm{t} 5$ & 300 & 0,110631 & 0,118815 & 0,018519 & 0,716947 & 0,021743 & 0,460958 & 0,100742 & & 0,135501 & 0,005805 & 0,091948 & 0,404467 \\
\hline $\mathrm{t} 7$ & 60 & 0,984583 & 0,980568 & 0,386766 & 0,225026 & 0,648924 & 0,026704 & 0,982877 & 0,135501 & & 0,000163 & 0,994605 & 0,006512 \\
\hline t7 & 300 & 0,000142 & 0,000131 & 0,000173 & 0,003083 & 0,000121 & 0,024522 & 0,000139 & 0,005805 & 0,000163 & & 0,000134 & 0,036353 \\
\hline t8 & 60 & 0,971509 & 0,952606 & 0,795108 & 0,11737 & 0,863453 & 0,022185 & 0,772318 & 0,091948 & 0,994605 & 0,000134 & & 0,006461 \\
\hline t8 & 300 & 0,005552 & 0,007246 & 0,000553 & 0,354805 & 0,000617 & 0,583737 & 0,010678 & 0,404467 & 0,006512 & 0,036353 & 0,006461 & \\
\hline
\end{tabular}


Anexo I - Tabela 4. Tabelas de significância de ANOVA e teste post hoc de Newman-Keuls para (A) Carbono, (B) Hidrogênio e (C) Nitrogênio.

\begin{tabular}{|c|c|c|c|c|c|c|c|c|c|c|c|c|c|}
\hline $\begin{array}{r}\text { A - Carbono } \\
\text { ANOVA }\end{array}$ & $\begin{array}{l}\text { Soma dos } \\
\text { quadrados }\end{array}$ & $\begin{array}{l}\text { Grau de } \\
\text { liberdade }\end{array}$ & $\begin{array}{c}\text { Média } \\
\text { quadrada }\end{array}$ & $\mathbf{F}$ & p & & & & & & & & \\
\hline Intercepto & 2723686 & 1 & 2723686 & 5835,119 & 0,000000 & & & & & & & & \\
\hline Irradiância & 68 & 1 & 68 & 0,145 & 0,706742 & & & & & & & & \\
\hline Tempo & 2842 & 5 & 568 & 1,218 & 0,331126 & & & & & & & & \\
\hline Irradiância*Tempo & 5556 & 5 & 1111 & 2,380 & 0,068823 & & & & & & & & \\
\hline Erro & 11203 & 24 & 467 & & & & & & & & & & \\
\hline \multicolumn{14}{|l|}{ Newman-Keuls } \\
\hline Tempo & Irradiância & to -60 & $t 1-60$ & $t 3-60$ & t5 -60 & t7 - 60 & t8 - 60 & to -300 & $\mathrm{t} 1-300$ & $\mathrm{t} 3-300$ & t5 -300 & t7 -300 & t8 - 300 \\
\hline to & 60 & & 0,212585 & 0,701739 & 0,710969 & 0,756169 & 0,768841 & 0,783259 & 0,856009 & 0,616035 & 0,577267 & 0,707936 & 0,661498 \\
\hline $\mathrm{t} 1$ & 60 & 0,212585 & & 0,744967 & 0,662290 & 0,500991 & 0,138056 & 0,471209 & 0,258480 & 0,805808 & 0,452908 & 0,665929 & 0,765650 \\
\hline t3 & 60 & 0,701739 & 0,744967 & & 0,926400 & 0,995651 & 0,597657 & 0,865813 & 0,717666 & 0,989033 & 0,973036 & 0,973165 & 0,848126 \\
\hline t5 & 60 & 0,710969 & 0,662290 & 0,926400 & & 0,989800 & 0,653683 & 0,692847 & 0,654224 & 0,722695 & 0,954111 & 0,974442 & 0,940985 \\
\hline t7 & 60 & 0,756169 & 0,500991 & 0,995651 & 0,989800 & & 0,625540 & 0,948303 & 0,805487 & 0,999207 & 0,711494 & 0,994060 & 0,999332 \\
\hline t8 & 60 & 0,768841 & 0,138056 & 0,597657 & 0,653683 & 0,625540 & & 0,769252 & 0,880977 & 0,528898 & 0,437872 & 0,580929 & 0,542761 \\
\hline to & 300 & 0,783259 & 0,471209 & 0,865813 & 0,692847 & 0,948303 & 0,769252 & & 0,631512 & 0,731156 & 0,858354 & 0,914820 & 0,867229 \\
\hline t1 & 300 & 0,856009 & 0,258480 & 0,717666 & 0,654224 & 0,805487 & 0,880977 & 0,631512 & & 0,605296 & 0,642597 & 0,752403 & 0,695721 \\
\hline t3 & 300 & 0,616035 & 0,805808 & 0,989033 & 0,722695 & 0,999207 & 0,528898 & 0,731156 & 0,605296 & & 0,988583 & 0,995277 & 0,976586 \\
\hline t5 & 300 & 0,577267 & 0,452908 & 0,973036 & 0,954111 & 0,711494 & 0,437872 & 0,858354 & 0,642597 & 0,988583 & & 0,923011 & 0,976126 \\
\hline t7 & 300 & 0,707936 & 0,665929 & 0,973165 & 0,974442 & 0,994060 & 0,580929 & 0,914820 & 0,752403 & 0,995277 & 0,923011 & & 0,977344 \\
\hline t8 & 300 & 0,661498 & 0,765650 & 0,848126 & 0,940985 & 0,999332 & 0,542761 & 0,867229 & 0,695721 & 0,976586 & 0,976126 & 0,977344 & \\
\hline \multicolumn{14}{|l|}{ B - Hidrogênio } \\
\hline & $\begin{array}{l}\text { Soma dos } \\
\text { quadrados }\end{array}$ & $\begin{array}{l}\text { Grau de } \\
\text { liberdade }\end{array}$ & $\begin{array}{c}\text { Média } \\
\text { quadrada }\end{array}$ & $\mathbf{F}$ & p & & & & & & & & \\
\hline \multicolumn{14}{|c|}{ q a } \\
\hline Intercepto & 79090,46 & 1 & 79090,46 & 6312,027 & 0,000000 & & & & & & & & \\
\hline Irradiância & 80,66 & 1 & 80,66 & 6,438 & 0,018087 & & & & & & & & \\
\hline Tempo & 95,44 & 5 & 19,09 & 1,523 & 0,219937 & & & & & & & & \\
\hline Irradiância*Tempo & 81,94 & 5 & 16,39 & 1,308 & 0,293878 & & & & & & & & \\
\hline Erro & 300,72 & 24 & 12,53 & & & & & & & & & & \\
\hline \multicolumn{14}{|l|}{ Newman-Keuls } \\
\hline Tempo & Irradiância & to -60 & $t 1-60$ & $\mathrm{t} 3-60$ & t5 -60 & $t 7-60$ & t8 - 60 & to -300 & $\mathrm{t} 1-300$ & t3 - 300 & t5 -300 & t7 -300 & t8 - 300 \\
\hline to & 60 & & 0,438701 & 0,421944 & 0,696114 & 0,437511 & 0,584989 & 0,601560 & 0,735122 & 0,653252 & 0,194435 & 0,207953 & 0,089557 \\
\hline $\mathrm{t} 1$ & 60 & 0,438701 & & 0,850089 & 0,847373 & 0,928138 & 0,873185 & 0,712608 & 0,816219 & 0,830400 & 0,773932 & 0,889646 & 0,739508 \\
\hline t3 & 60 & 0,421944 & 0,850089 & & 0,958617 & 0,857101 & 0,857904 & 0,938432 & 0,976027 & 0,953095 & 0,573003 & 0,603301 & 0,346286 \\
\hline t5 & 60 & 0,696114 & 0,847373 & 0,958617 & & 0,875262 & 0,924166 & 0,918350 & 0,894588 & 0,904083 & 0,623769 & 0,670017 & 0,417339 \\
\hline t7 & 60 & 0,437511 & 0,928138 & 0,857101 & 0,875262 & & 0,887515 & 0,888622 & 0,866261 & 0,905780 & 0,557747 & 0,807916 & 0,675234 \\
\hline t8 & 60 & 0,584989 & 0,873185 & 0,857904 & 0,924166 & 0,887515 & & 0,946018 & 0,971280 & 0,952234 & 0,629540 & 0,666656 & 0,406966 \\
\hline to & 300 & 0,601560 & 0,712608 & 0,938432 & 0,918350 & 0,888622 & 0,946018 & & 0,869662 & 0,835336 & 0,717183 & 0,810232 & 0,610089 \\
\hline t1 & 300 & 0,735122 & 0,816219 & 0,976027 & 0,894588 & 0,866261 & 0,971280 & 0,869662 & & 0,770841 & 0,628601 & 0,686940 & 0,443187 \\
\hline t3 & 300 & 0,653252 & 0,830400 & 0,953095 & 0,904083 & 0,905780 & 0,952234 & 0,835336 & 0,770841 & & 0,711874 & 0,782349 & 0,557923 \\
\hline t5 & 300 & 0,194435 & 0,773932 & 0,573003 & 0,623769 & 0,557747 & 0,629540 & 0,717183 & 0,628601 & 0,711874 & & 0,976033 & 0,854985 \\
\hline t7 & 300 & 0,207953 & 0,889646 & 0,603301 & 0,670017 & 0,807916 & 0,666656 & 0,810232 & 0,686940 & 0,782349 & 0,976033 & & 0,618548 \\
\hline t8 & 300 & 0,089557 & 0,739508 & 0,346286 & 0,417339 & 0,675234 & 0,406966 & 0,610089 & 0,443187 & 0,557923 & 0,854985 & 0,618548 & \\
\hline \multicolumn{14}{|l|}{ C - Nitrogênio } \\
\hline ANOVA & $\begin{array}{l}\text { Soma dos } \\
\text { quadrados }\end{array}$ & $\begin{array}{l}\text { Grau de } \\
\text { liberdade }\end{array}$ & $\begin{array}{c}\text { Média } \\
\text { quadrada }\end{array}$ & $F$ & p & & & & & & & & \\
\hline Intercepto & 25671,34 & 1 & 25671,34 & 4504,071 & 0,000000 & & & & & & & & \\
\hline Tempo & 58,93 & 1 & 58,93 & 10,339 & 0,003700 & & & & & & & & \\
\hline Irradiância & 26,12 & 5 & 5,22 & 0,917 & 0,487069 & & & & & & & & \\
\hline Tempo*Irradiância & 174,63 & 5 & 34,93 & 6,128 & 0,000859 & & & & & & & & \\
\hline Erro & 136,79 & 24 & 5,70 & & & & & & & & & & \\
\hline \multicolumn{14}{|l|}{ Newman-Keuls } \\
\hline Tempo & Irradiância & to -60 & $\mathrm{t} 1-60$ & $\mathrm{t} 3-60$ & t5 - 60 & $\mathrm{t} 7-60$ & t8 - 60 & to -300 & $\mathrm{t} 1-300$ & $\mathrm{t} 3-300$ & t5 -300 & t7 - 300 & t8 - 300 \\
\hline to & 60 & & 0,694259 & 0,740976 & 0,015720 & 0,510856 & 0,672844 & 0,642583 & 0,642257 & 0,837050 & 0,751127 & 0,653568 & 0,865899 \\
\hline t1 & 60 & 0,694259 & & 0,624088 & 0,007614 & 0,344228 & 0,524637 & 0,570111 & 0,475588 & 0,818256 & 0,746377 & 0,768081 & 0,925739 \\
\hline t3 & 60 & 0,740976 & 0,624088 & & 0,066505 & 0,823462 & 0,753680 & 0,911339 & 0,860452 & 0,700945 & 0,518714 & 0,292720 & 0,566430 \\
\hline t5 & 60 & 0,015720 & 0,007614 & 0,066505 & & 0,063292 & 0,086518 & 0,071335 & 0,077039 & 0,020122 & 0,004240 & 0,001318 & 0,004488 \\
\hline t7 & 60 & 0,510856 & 0,344228 & 0,823462 & 0,063292 & & 0,849590 & 0,863291 & 0,737368 & 0,561463 & 0,235128 & 0,092920 & 0,247140 \\
\hline t8 & 60 & 0,672844 & 0,524637 & 0,753680 & 0,086518 & 0,849590 & & 0,903468 & 0,838269 & 0,676899 & 0,405760 & 0,199144 & 0,437922 \\
\hline to & 300 & 0,642583 & 0,570111 & 0,911339 & 0,071335 & 0,863291 & 0,903468 & & 0,919157 & 0,492761 & 0,493604 & 0,297210 & 0,558431 \\
\hline t1 & 300 & 0,642257 & 0,475588 & 0,860452 & 0,077039 & 0,737368 & 0,838269 & 0,919157 & & 0,673791 & 0,350454 & 0,157426 & 0,372216 \\
\hline t3 & 300 & 0,837050 & 0,818256 & 0,700945 & 0,020122 & 0,561463 & 0,676899 & 0,492761 & 0,673791 & & 0,787410 & 0,621684 & 0,861153 \\
\hline t5 & 300 & 0,751127 & 0,746377 & 0,518714 & 0,004240 & 0,235128 & 0,405760 & 0,493604 & 0,350454 & 0,787410 & & 0,798810 & 0,962498 \\
\hline t7 & 300 & 0,653568 & 0,768081 & 0,292720 & 0,001318 & 0,092920 & 0,199144 & 0,297210 & 0,157426 & 0,621684 & 0,798810 & & 0,558135 \\
\hline t8 & 300 & 0,865899 & 0,925739 & 0,566430 & 0,004488 & 0,247140 & 0,437922 & 0,558431 & 0,372216 & 0,861153 & 0,962498 & 0,558135 & \\
\hline
\end{tabular}


Anexo I - Tabela 5. Tabelas de significância de ANOVA e teste post hoc de Newman-Keuls para (A) Ficoeritrina, (B) Aloficocianina e (C) Ficocianina.

\begin{tabular}{|c|c|c|c|c|c|c|c|c|c|c|c|c|c|}
\hline \multicolumn{14}{|l|}{ A - Ficoeritrina } \\
\hline ANOVA & $\begin{array}{l}\text { Soma dos } \\
\text { quadrados }\end{array}$ & $\begin{array}{l}\text { Grau de } \\
\text { liberdade }\end{array}$ & $\begin{array}{c}\text { Média } \\
\text { quadrada }\end{array}$ & $\mathbf{F}$ & p & & & & & & & & \\
\hline Intercepto & 87173834 & 1 & 87173834 & 4183,076 & 0,000000 & & & & & & & & \\
\hline Tempo & 2282717 & 5 & 456543 & 21,907 & 0,000000 & & & & & & & & \\
\hline Irradiância & 1378990 & 1 & 1378990 & 66,171 & 0,000000 & & & & & & & & \\
\hline Tempo*Irradiância & 1595435 & 5 & 319087 & 15,312 & 0,000000 & & & & & & & & \\
\hline Erro & 583510 & 28 & 20840 & & & & & & & & & & \\
\hline \multicolumn{14}{|l|}{ Newman-Keuls } \\
\hline Tempo & Irradiância & to -60 & to -300 & $t 1-60$ & $t 1-300$ & $\mathrm{t} 3-60$ & t3 -300 & t5 -60 & t5 -300 & $t 7-60$ & t7 -300 & t8 -60 & t8 -300 \\
\hline to & 60 & & 0,001624 & 0,000135 & 0,001632 & 0,001990 & 0,000163 & 0,000142 & 0,000148 & 0,001642 & 0,000189 & 0,272478 & 0,000145 \\
\hline to & 300 & & 0,001624 & 0,000135 & 0,001632 & 0,001990 & 0,000163 & 0,000142 & 0,000148 & 0,001642 & 0,000189 & 0,272478 & 0,000145 \\
\hline $\mathrm{t} 1$ & 60 & 0,000135 & 0,031813 & & 0,048683 & 0,023820 & 0,217916 & 0,428835 & 0,451624 & 0,049497 & 0,097281 & 0,000145 & 0,405752 \\
\hline $\mathrm{t} 1$ & 300 & 0,001632 & 0,807025 & 0,048683 & & 0,924948 & 0,001335 & 0,006906 & 0,005356 & 0,805713 & 0,000467 & 0,000248 & 0,012359 \\
\hline $\mathrm{t} 3$ & 60 & 0,001990 & 0,887712 & 0,023820 & 0,924948 & & 0,001256 & 0,005600 & 0,004815 & 0,937213 & 0,000474 & 0,000258 & 0,008547 \\
\hline t3 & 300 & 0,000163 & 0,000497 & 0,217916 & 0,001335 & 0,001256 & & 0,634807 & 0,503621 & 0,000930 & 0,573224 & 0,000189 & 0,550907 \\
\hline $\mathrm{t} 5$ & 60 & 0,000142 & 0,002700 & 0,428835 & 0,006906 & 0,005600 & 0,634807 & & 0,813362 & 0,005225 & 0,458840 & 0,000148 & 0,680694 \\
\hline t5 & 300 & 0,000148 & 0,001904 & 0,451624 & 0,005356 & 0,004815 & 0,503621 & 0,813362 & & 0,003825 & 0,435820 & 0,000163 & 0,791458 \\
\hline t7 & 60 & 0,001642 & 0,708429 & 0,049497 & 0,805713 & 0,937213 & 0,000930 & 0,005225 & 0,003825 & & 0,000350 & 0,000291 & 0,010448 \\
\hline $\mathrm{t} 7$ & 300 & 0,000189 & 0,000249 & 0,097281 & 0,000467 & 0,000474 & 0,573224 & 0,458840 & 0,435820 & 0,000350 & & 0,000137 & 0,339450 \\
\hline t8 & 60 & 0,272478 & 0,000324 & 0,000145 & 0,000248 & 0,000258 & 0,000189 & 0,000148 & 0,000163 & 0,000291 & 0,000137 & & 0,000142 \\
\hline t8 & 300 & 0,000145 & 0,005747 & 0,405752 & 0,012359 & 0,008547 & 0,550907 & 0,680694 & 0,791458 & 0,010448 & 0,339450 & 0,000142 & \\
\hline \multicolumn{14}{|l|}{ B - Aloficocianina } \\
\hline ANOVA & $\begin{array}{l}\text { Soma dos } \\
\text { quadrados }\end{array}$ & $\begin{array}{l}\text { Grau de } \\
\text { liberdade }\end{array}$ & $\begin{array}{c}\text { Média } \\
\text { quadrada }\end{array}$ & $\mathbf{F}$ & p & & & & & & & & \\
\hline Intercepto & 3225423 & 1 & 3225423 & 3255,141 & 0,000000 & & & & & & & & \\
\hline Tempo & 63416 & 5 & 12683 & 12,800 & 0,000001 & & & & & & & & \\
\hline Irradiância & 62833 & 1 & 62833 & 63,412 & 0,000000 & & & & & & & & \\
\hline Tempo*Irradiância & 32223 & 5 & 6445 & 6,504 & 0,000261 & & & & & & & & \\
\hline Erro & 32699 & 33 & 991 & & & & & & & & & & \\
\hline \multicolumn{14}{|l|}{ Newman-Keuls } \\
\hline Tempo & Irradiância & to -60 & to -300 & $t 1-60$ & $t 1-300$ & $\mathrm{t} 3-60$ & t3 -300 & t5 - 60 & t5 -300 & $t 7-60$ & t7 -300 & t8 -60 & t8 -300 \\
\hline to & 60 & & 0,000130 & 0,000157 & 0,000144 & 0,000619 & 0,000137 & 0,000134 & 0,000183 & 0,000289 & 0,000131 & 0,119328 & 0,000136 \\
\hline to & 300 & & 0,000130 & 0,000157 & 0,000144 & 0,000619 & 0,000137 & 0,000134 & 0,000183 & 0,000289 & 0,000131 & 0,119328 & 0,000136 \\
\hline $\mathrm{t} 1$ & 60 & 0,000157 & 0,954500 & & 0,956738 & 0,050186 & 0,872536 & 0,939949 & 0,629097 & 0,175607 & 0,338559 & 0,000181 & 0,964964 \\
\hline $\mathrm{t} 1$ & 300 & 0,000144 & 0,928777 & 0,956738 & & 0,045615 & 0,660194 & 0,863843 & 0,851045 & 0,155550 & 0,459014 & 0,000171 & 0,932036 \\
\hline $\mathrm{t} 3$ & 60 & 0,000619 & 0,059254 & 0,050186 & 0,045615 & & 0,095389 & 0,082351 & 0,018627 & 0,498809 & 0,001891 & 0,013363 & 0,066241 \\
\hline t3 & 300 & 0,000137 & 0,984307 & 0,872536 & 0,660194 & 0,095389 & & 0,942437 & 0,758210 & 0,266064 & 0,323829 & 0,000246 & 0,987075 \\
\hline t5 & 60 & 0,000134 & 0,956842 & 0,939949 & 0,863843 & 0,082351 & 0,942437 & & 0,825743 & 0,217475 & 0,364199 & 0,000230 & 0,935806 \\
\hline t5 & 300 & 0,000183 & 0,826951 & 0,629097 & 0,851045 & 0,018627 & 0,758210 & 0,825743 & & 0,078436 & 0,353994 & 0,000166 & 0,860859 \\
\hline $\mathrm{t} 7$ & 60 & 0,000289 & 0,100026 & 0,175607 & 0,155550 & 0,498809 & 0,266064 & 0,217475 & 0,078436 & & 0,009613 & 0,006474 & 0,156123 \\
\hline $\mathrm{t} 7$ & 300 & 0,000131 & 0,332539 & 0,338559 & 0,459014 & 0,001891 & 0,323829 & 0,364199 & 0,353994 & 0,009613 & & 0,000183 & 0,386884 \\
\hline t8 & 60 & 0,119328 & 0,000253 & 0,000181 & 0,000171 & 0,013363 & 0,000246 & 0,000230 & 0,000166 & 0,006474 & 0,000183 & & 0,000220 \\
\hline t8 & 300 & 0,000136 & 0,841197 & 0,964964 & 0,932036 & 0,066241 & 0,987075 & 0,935806 & 0,860859 & 0,156123 & 0,386884 & 0,000220 & \\
\hline \multicolumn{14}{|l|}{ C - Ficocianina } \\
\hline ANOVA & $\begin{array}{l}\text { Soma dos } \\
\text { quadrados }\end{array}$ & $\begin{array}{l}\text { Grau de } \\
\text { liberdade }\end{array}$ & $\begin{array}{c}\text { Média } \\
\text { quadrada }\end{array}$ & $\mathbf{F}$ & p & & & & & & & & \\
\hline Intercepto & 3033752 & 1 & 3033752 & 1899,533 & 0,000000 & & & & & & & & \\
\hline Tempo & 41964 & 5 & 8393 & 5,255 & 0,001056 & & & & & & & & \\
\hline Irradiância & 46090 & 1 & 46090 & 28,859 & 0,000005 & & & & & & & & \\
\hline Tempo*Irradiância & 29578 & 5 & 5916 & 3,704 & 0,008536 & & & & & & & & \\
\hline Erro & 55899 & 35 & 1597 & & & & & & & & & & \\
\hline \multicolumn{14}{|l|}{ Newman-Keuls } \\
\hline Tempo & Irradiância & to -60 & to -300 & $t 1-60$ & $t 1-300$ & $t 3-60$ & t3 -300 & t5 - 60 & t5 -300 & $t 7-60$ & t7 -300 & t8 -60 & t8 -300 \\
\hline to & 60 & & 0,189495 & 0,059649 & 0,064538 & 0,376696 & 0,053586 & 0,076407 & 0,027752 & 0,146237 & 0,012990 & 0,028311 & 0,033539 \\
\hline to & 300 & & 0,189495 & 0,059649 & 0,064538 & 0,376696 & 0,053586 & 0,076407 & 0,027752 & 0,146237 & 0,012990 & 0,028311 & 0,033539 \\
\hline t1 & 60 & 0,059649 & 0,652132 & & 0,937661 & 0,268059 & 0,965012 & 0,804272 & 0,959951 & 0,744465 & 0,902349 & 0,000283 & 0,951083 \\
\hline t1 & 300 & 0,064538 & 0,769631 & 0,937661 & & 0,300543 & 0,861633 & 0,942350 & 0,931726 & 0,810797 & 0,872061 & 0,000277 & 0,893969 \\
\hline t3 & 60 & 0,376696 & 0,487566 & 0,268059 & 0,300543 & & 0,274217 & 0,294221 & 0,177764 & 0,309559 & 0,098640 & 0,008432 & 0,200150 \\
\hline t3 & 300 & 0,053586 & 0,783622 & 0,965012 & 0,861633 & 0,274217 & & 0,957554 & 0,906245 & 0,801482 & 0,862223 & 0,000241 & 0,784184 \\
\hline t5 & 60 & 0,076407 & 0,528412 & 0,804272 & 0,942350 & 0,294221 & 0,957554 & & 0,936608 & 0,729334 & 0,853548 & 0,000343 & 0,934584 \\
\hline t5 & 300 & 0,027752 & 0,704590 & 0,959951 & 0,931726 & 0,177764 & 0,906245 & 0,936608 & & 0,694282 & 0,722279 & 0,000217 & 0,883880 \\
\hline t7 & 60 & 0,146237 & 0,902405 & 0,744465 & 0,810797 & 0,309559 & 0,801482 & 0,729334 & 0,694282 & & 0,523289 & 0,001042 & 0,718727 \\
\hline t7 & 300 & 0,012990 & 0,545070 & 0,902349 & 0,872061 & 0,098640 & 0,862223 & 0,853548 & 0,722279 & 0,523289 & & 0,000141 & 0,869122 \\
\hline t8 & 60 & 0,028311 & 0,001148 & 0,000283 & 0,000277 & 0,008432 & 0,000241 & 0,000343 & 0,000217 & 0,001042 & 0,000141 & & 0,000205 \\
\hline t8 & 300 & 0,033539 & 0,716399 & 0,951083 & 0,893969 & 0,200150 & 0,784184 & 0,934584 & 0,883880 & 0,718727 & 0,869122 & 0,000205 & \\
\hline
\end{tabular}


Anexo I - Tabela 6. Tabelas de significância de ANOVA e teste post hoc de Newman-Keuls para (A) Clorofila $a$, (B) Carotenoides e (C) Proteínas solúveis totais.

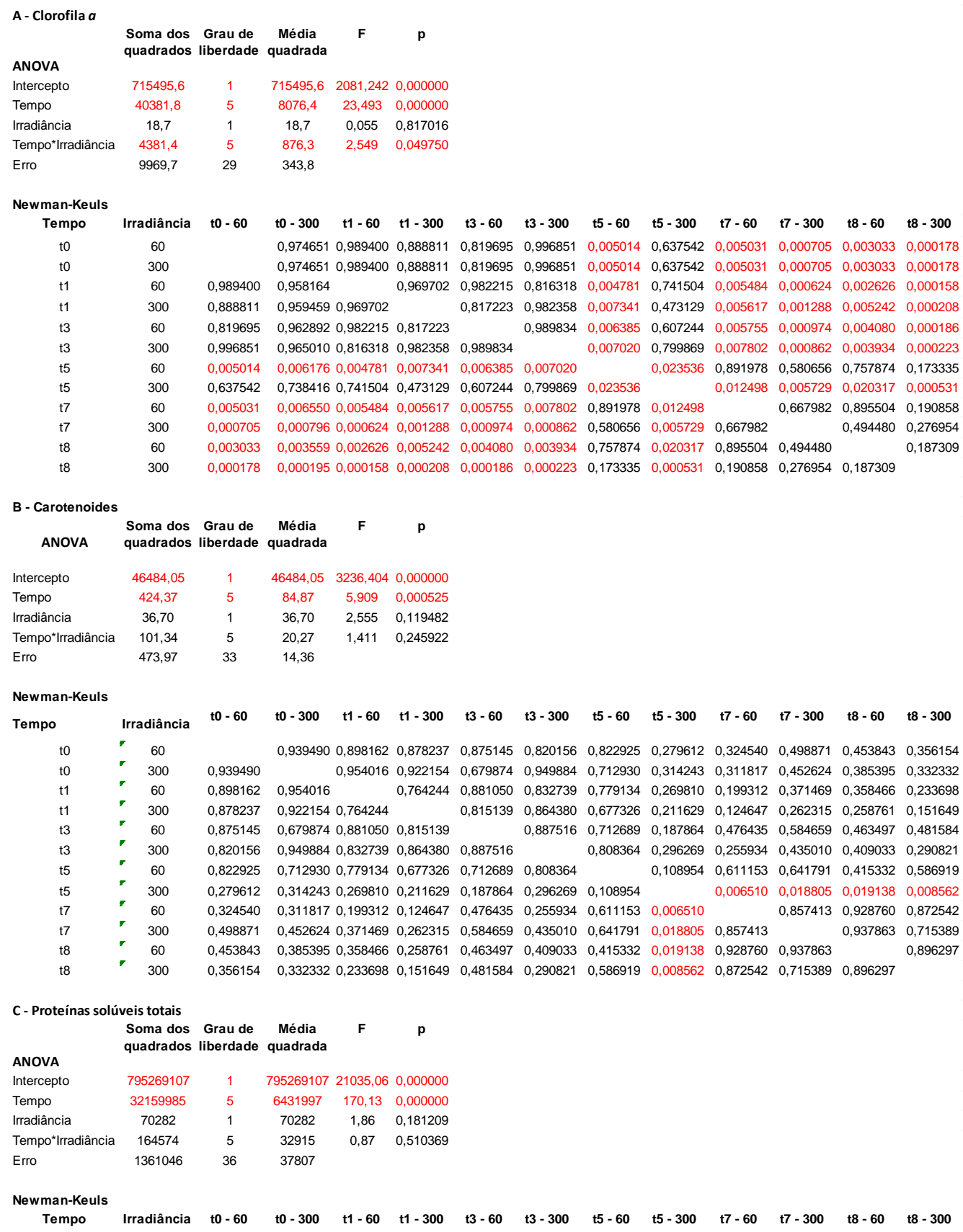

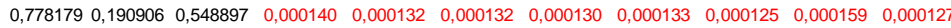
$\begin{array}{lllllllllllll}0,778179 & 0,190906 & 0,548897 & 0,000140 & 0,000132 & 0,000132 & 0,000130 & 0,000133 & 0,000125 & 0,000159 & 0,000127\end{array}$ $\begin{array}{llllllllllll}0,190906 & 0,197190 & 0,327987 & 0,000127 & 0,000179 & 0,000140 & 0,000153 & 0,000125 & 0,000132 & 0,000130 & 0,000132\end{array}$ $\begin{array}{lllllllllllll}0,548897 & 0,446926 & 0,327987 & 0,000179 & 0,000153 & 0,000132 & 0,000140 & 0,000160 & 0,000130 & 0,000132 & 0,000125\end{array}$

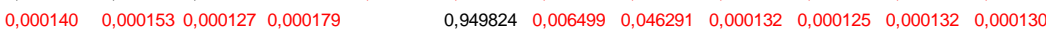

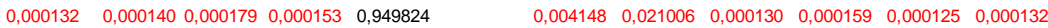

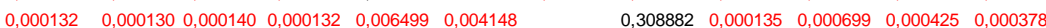
$\begin{array}{lllllllllll}0,000130 & 0,000132 & 0,000153 & 0,000140 & 0,046291 & 0,021006 & 0,308882 & 0,000132 & 0,000196 & 0,000185 & 0,000137\end{array}$ $\begin{array}{lllllllllll}0,000133 & 0,000140 & 0,000125 & 0,000160 & 0,000132 & 0,000130 & 0,000135 & 0,000132 & 0,213516 & 0,345163 & 0,281652\end{array}$

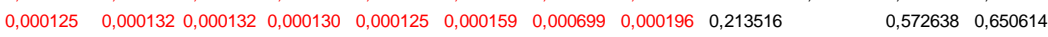
$\begin{array}{lllllllllll}0,000159 & 0,000125 & 0,000130 & 0,000132 & 0,000132 & 0,000125 & 0,000425 & 0,000185 & 0,345163 & 0,572638 & 0,751254\end{array}$ $\begin{array}{lllllllllll}0,000127 & 0,000159 & 0,000132 & 0,000125 & 0,000130 & 0,000132 & 0,000378 & 0,000137 & 0,281652 & 0,650614 & 0,751254\end{array}$ 


\section{ANEXO II - Curvas padrões de BSA para quantificação de proteínas solúveis totais}

Devido à alta quantidade de amostras a serem analisadas, o teor de proteínas solúveis totais foram avaliados em dias diferentes e, portanto, foi necessário realizar curvas padrões diferentes para cada conjunto de análises.

A Figura AII-1 mostra as curvas realizadas com o padrão de soro de albumina bovina (BSA) em concentrações de 2 a $16 \mu \mathrm{g} \cdot \mathrm{mL}^{-1}$ para análise de proteínas solúveis totais. $\mathrm{Na}$ Figura AII-1A, está representada a equação da reta e $\mathrm{R}^{\mathbf{2}}$ para a curva padrão utilizada para amostras dos tempos 0 e 1 de 60 e $300 \mu$ mol fótons.m ${ }^{-2} . \mathrm{s}^{-1}$. A Figura AII-1B representa a equação da reta e $\mathrm{R}^{2}$ da curva de calibração utilizada para as amostras dos tempos 3 e 5 de 60 e $300 \mu \mathrm{mol}$ fótons. $\mathrm{m}^{-2} \cdot \mathrm{s}^{-1}$. A Figura AII-1C exibe a equação da reta e $\mathrm{R}^{2}$ de curva padrão utilizada para análise das amostras dos tempos 7 e 8 de 60 e $300 \mu \mathrm{mol}$ fótons.m ${ }^{-2} \cdot \mathrm{s}^{-1}$.

Todas as curvas de calibração apresentaram regressões acima de 0,96, indicando ajustes apropriados para o cálculo de proteínas solúveis totais.

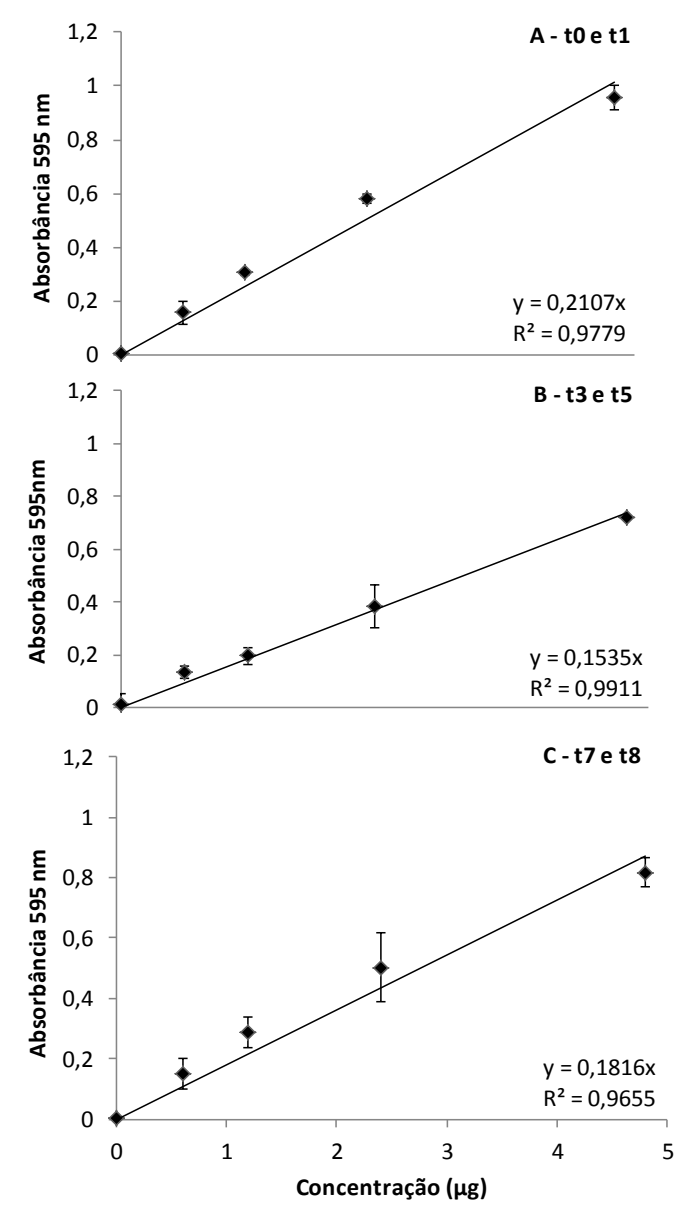

Anexo II - Figura 1. Curvas padrões de BSA para proteínas solúveis totais para amostras dos tempos (A) t0 e t1, (B) t3 e t5 (C) t7 e t8 para 60 e $300 \mu$ mol fótons. $\mathrm{m}^{-2} \cdot \mathrm{s}^{-1}$. 


\section{ANEXO III - Potencial antioxidante de extratos metanólicos de $P$. capillacea}

O potencial de atividade antioxidante foi avaliada mediante cinco ensaios diferentes, para os quais os tratamentos de irradiância e tempos de exposição foram analisados em seis concentrações de extrato bruto metanólico de P. capillacea: $0,6,8,10,12$ e 13,3 mg.mL $\mathrm{mL}^{-1}$. O objetivo de estudar diferentes concentrações de extrato bruto foi calcular os valores de EC50 (concentração efetiva à qual é alcançada a metade da resposta entre a taxa inicial e a máxima após um determinado tempo) e compará-los entre os tratamentos e a literatura. O EC50 representa uma curva de dose resposta e a eficiência do extrato no seu potencial antioxidante, parâmetro relevante para fins de aplicação bioativa. Ao final deste anexo, encontram-se as análises estatísticas em tabelas de ANOVA e teste post hoc de Newman-Keuls para todas as métricas apresentados no Capítulo II (Tabelas AIII-7-14).

\section{Poder redutor para o sequestro do radical DPPH}

A Figura AIII-1 apresenta as curvas de dose-resposta em relação à concentração de extrato bruto algal e absorbância da reação para as irradiâncias de $60 \mu \mathrm{mol}$ fótons. $\mathrm{m}^{-2} \cdot \mathrm{s}^{-1}$ (Fig. AIII-1A-F) e $300 \mu \mathrm{mol}$ fótons.m ${ }^{-2} \cdot \mathrm{s}^{-1}$ (Fig. AIII-1G-L) para o ensaio de DPPH. A atividade antioxidante não variou significativamente entre as concentrações de extrato bruto. A máxima atividade, com a maior concentração do extrato metanólico, não alcançou o 50\% de atividade, pelo qual foi possível calcular os valores de EC50 (Fig. AIII-2A-E). Sendo assim, no Capítulo II foram apresentados apenas os valores de porcentagem de atividade antioxidante e sua equivalência em concentração dos padrões ácido gálico e Trolox, com base na maior concentração de extrato bruto algáceo $\left(13,3 \mathrm{mg} \cdot \mathrm{mL}^{-1}\right)$.

Os resultados aqui expostos demonstram a necessidade de testar-se concentrações maiores de extrato metanólico bruto de $P$. capillacea para avaliar o potential antioxidante mediante o ensaio de DPPH. 

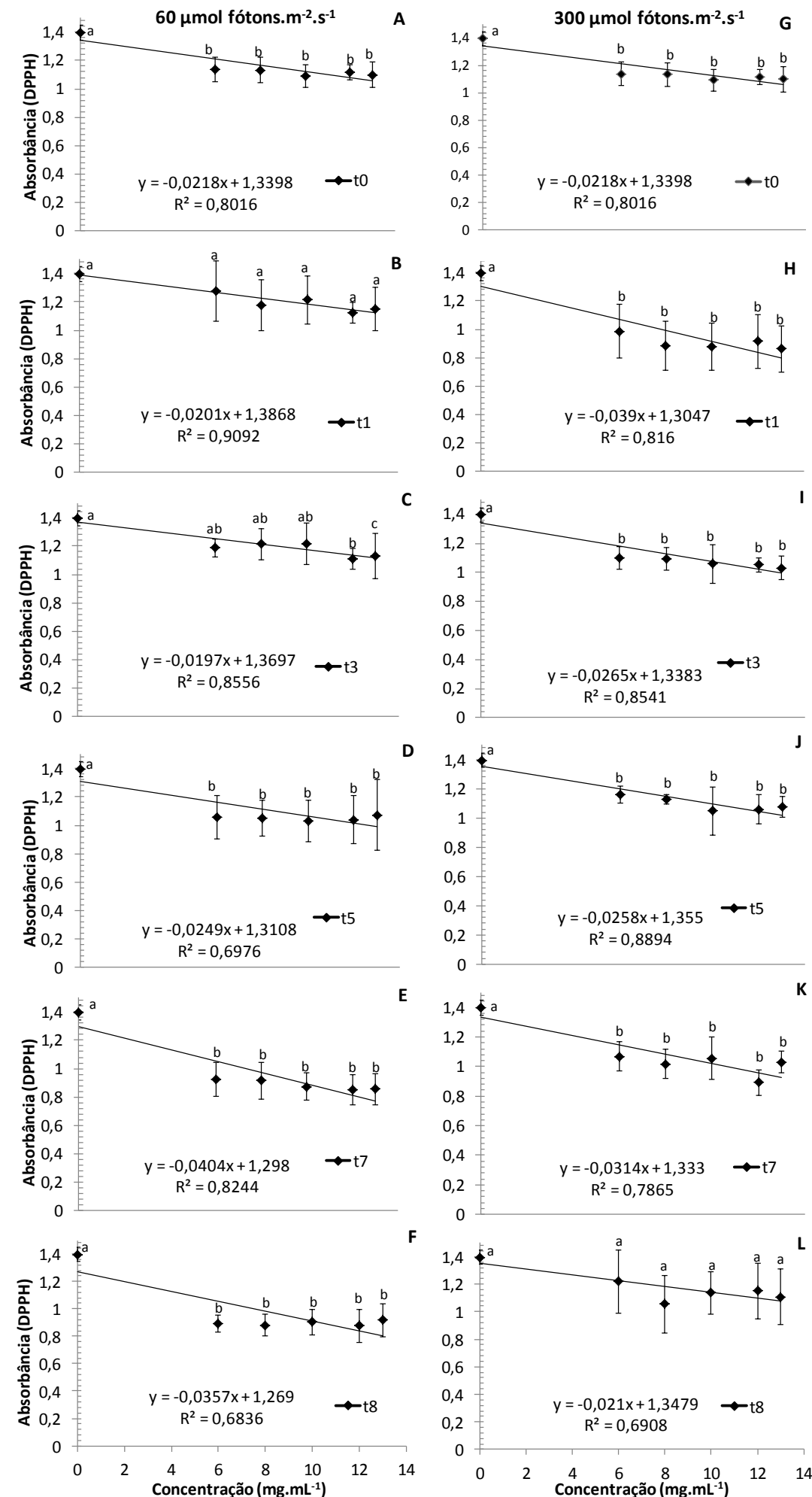

Anexo III - Figura 1. Curva de dose-resposta (concentração de extrato bruto: 0, 6, 8, 10, 12 e $13,3 \mathrm{mg} \cdot \mathrm{mL}^{-1}$ versus a absorbância da reação) para $P$. capillacea estimada para cada um dos tempos de exposição sob as irradiâncias de $60 \mu \mathrm{mol}$ fótons.m ${ }^{-2} \cdot \mathrm{s}^{-1}$ (A-F) e $300 \mu \mathrm{mol}$ fótons.m ${ }^{-}$ ${ }^{2} . \mathrm{s}^{-1}(\mathrm{G}-\mathrm{L})$ para o ensaio do DPPH. Letras diferentes indicam diferença significativa ( $<$ < 0,05), após a ANOVA e teste post-hoc de Newman-Keuls. 

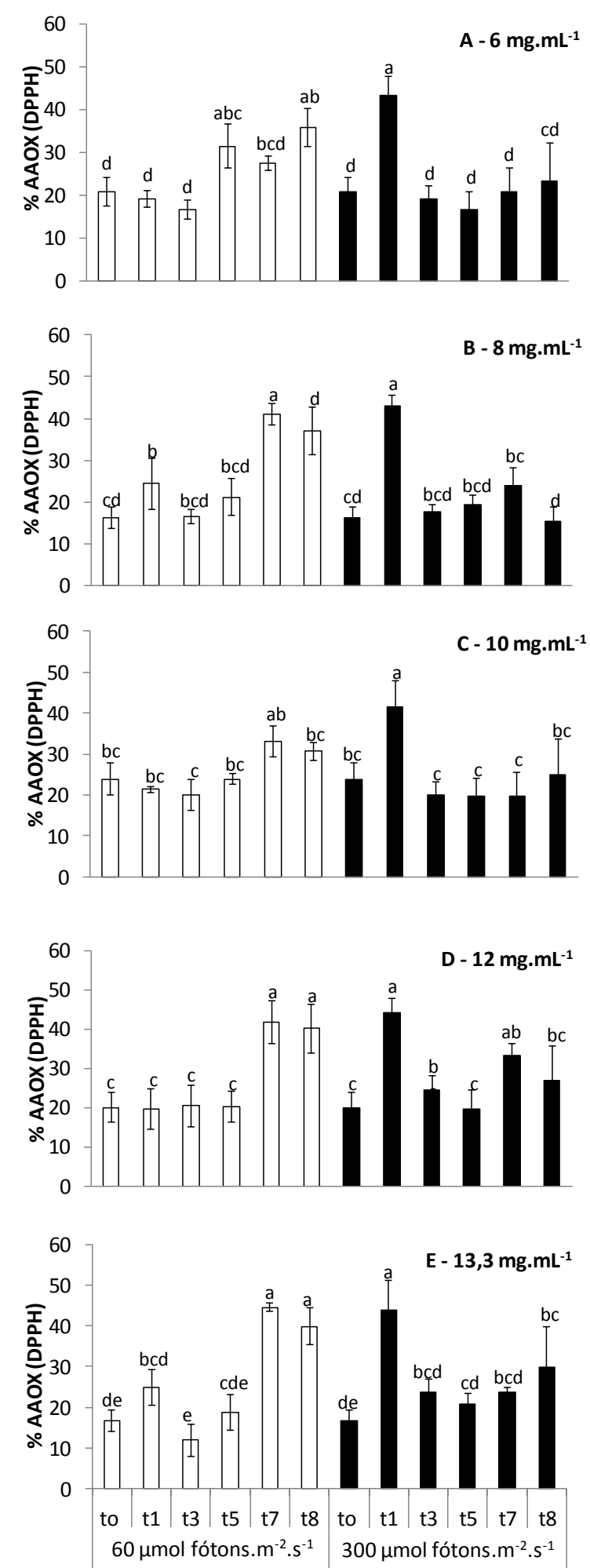

Anexo III - Figura 2. Atividade antioxidante percentual para cada uma das concentrações de extrato bruto de $P$. capillacea $\left(0,6,8,10,12\right.$ e 13,3 mg.mL $\left.\mathrm{mL}^{-1}\right)$ ao longo do tempo de exposição às irradiâncias de $60 \mu \mathrm{mol}$ fótons. $\mathrm{m}^{-2} . \mathrm{s}^{-1} \mathrm{e} 300 \mu \mathrm{mol}$ fótons. $\mathrm{m}^{-2} \cdot \mathrm{s}^{-1}$ para o ensaio do DPPH. Letras diferentes indicam diferença significativa $(\mathrm{p}<0,05)$, após a ANOVA e teste post-hoc de Newman-Keuls. 


\section{Captura do radical livre ABTS}

A Figura AIII-3 apresenta as curvas de dose-resposta em relação à concentração de extrato bruto algal e absorbância da reação para as irradiâncias de $60 \mu \mathrm{mol}$ fótons. $\mathrm{m}^{-2} \cdot \mathrm{s}^{-1}$ (Fig. AIII-3A-F) e $300 \mu \mathrm{mol}$ fótons.m ${ }^{-2} . \mathrm{s}^{-1}$ (Fig. AIII-3G-L) para o ensaio do ABTS.

A atividade antioxidante não variou significativamente entre as concentrações de extrato bruto (Fig. AIII-4A-E).

Foi observada uma tendência de estabilidade na atividade antioxidante nas concentrações 12 e 13,3 mg.mL ${ }^{-1}$. Sendo assim, no Capítulo II foram apresentados os valores de porcentagem de atividade antioxidante e sua equivalência em concentração dos padrões ácido gálico e Trolox com base na concentração de extrato bruto algáceo de $12 \mathrm{mg} \cdot \mathrm{mL}^{-1}$, além do cálculo de EC50 para as irradiâncias testadas ao longo do tempo. 

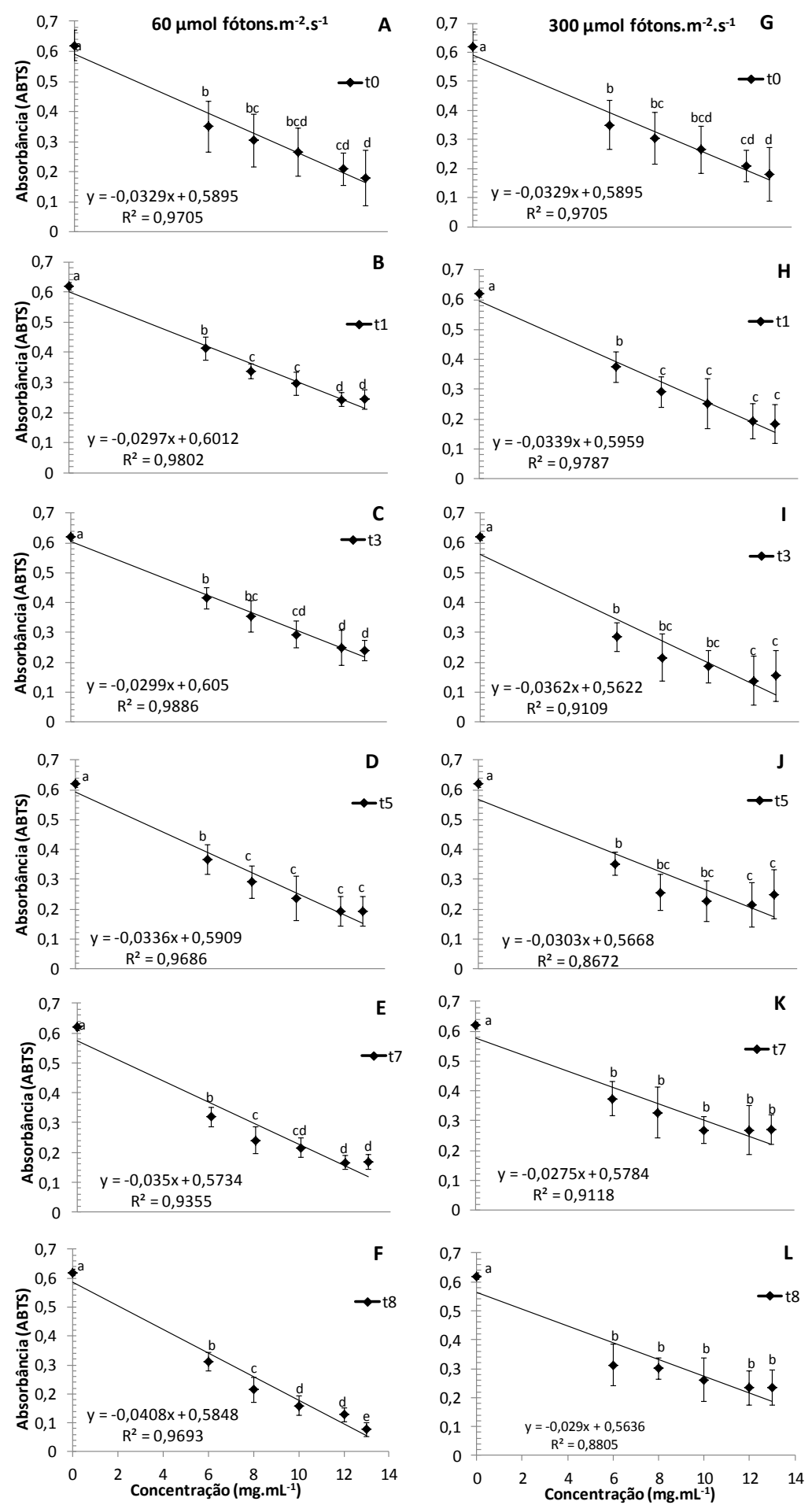

Anexo III - Figura 3. Curva de dose-resposta (concentração de extrato bruto: 0, 6, 8, 10, 12 e $13,3 \mathrm{mg} \cdot \mathrm{mL}^{-1}$ versus a absorbância da reação) para $P$. capillacea estimada para cada um dos tempos de exposição sob as irradiâncias de $60 \mu \mathrm{mol}$ fótons. $\mathrm{m}^{-2} \cdot \mathrm{s}^{-1}$ (A-F) e $300 \mu \mathrm{mol}$ fótons.m ${ }^{-}$ ${ }^{2} . \mathrm{s}^{-1}$ (G-L) para o ensaio do ABTS. Letras diferentes indicam diferença significativa ( $\mathrm{p}<$ 0,05), após a ANOVA e teste post-hoc de Newman-Keuls. 

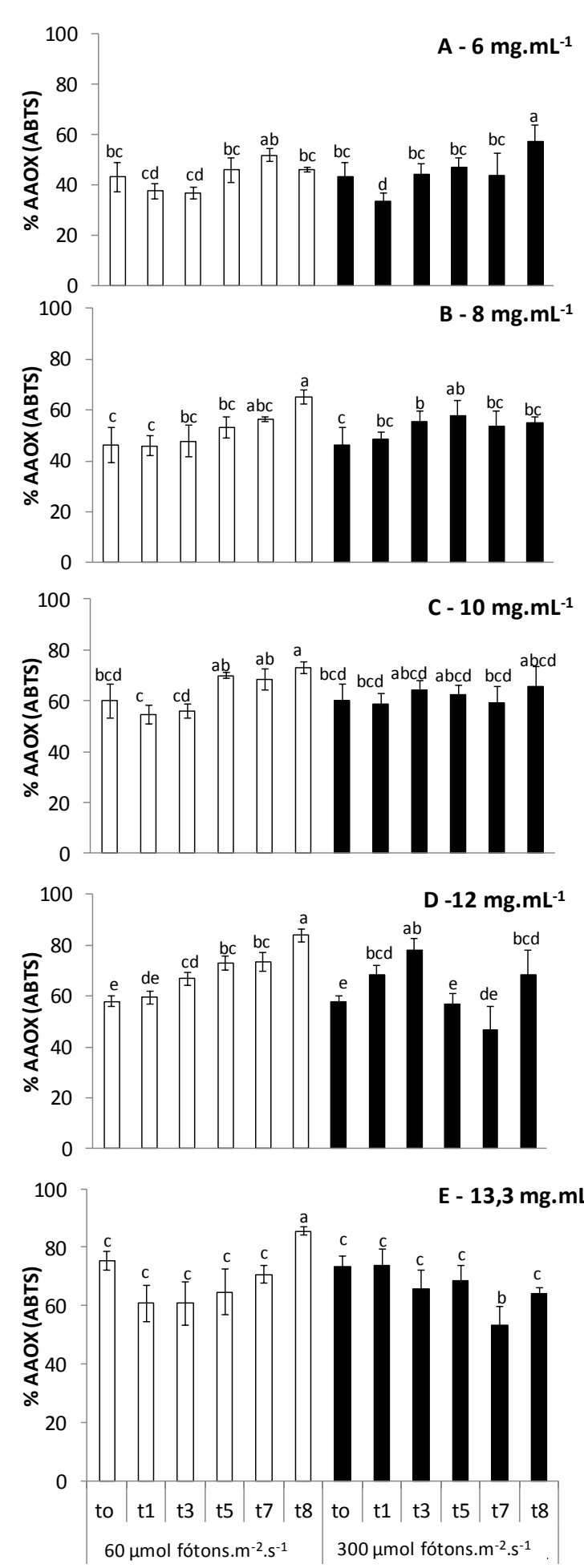

Anexo III - Figura 4. Atividade antioxidante percentual para cada uma das concentrações de extrato bruto de $P$. capillacea $\left(0,6,8,10,12\right.$ e 13,3 mg. $\left.\mathrm{mL}^{-1}\right)$ ao longo do tempo de exposição às irradiâncias de $60 \mu \mathrm{mol}$ fótons. $\mathrm{m}^{-2} . \mathrm{s}^{-1} \mathrm{e} 300 \mu \mathrm{mol}$ fótons. $\mathrm{m}^{-2} \cdot \mathrm{s}^{-1}$ para o ensaio do ABTS. Letras diferentes indicam diferença significativa $(\mathrm{p}<0,05)$, após a ANOVA e teste post-hoc

Newman-Keuls. 


\section{Atividade quelante de metais}

A Figura AIII-5 apresenta as curvas de dose-resposta em relação à concentração de extrato bruto algal e absorbância da reação para as irradiâncias de $60 \mu \mathrm{mol}$ fótons. $\mathrm{m}^{-2} . \mathrm{s}^{-1}$ (Fig. AIII-5A-F) e $300 \mu \mathrm{mol}$ fótons.m ${ }^{-2} . \mathrm{s}^{-1}$ (Fig. AIII-5G-L) para o ensaio quelante de metais. Foi observada uma tendência de estabilidade entre todas as concentrações. Dessa forma, não foi possível realizar os cálculos de EC50 para este ensaio.

A atividade antioxidante não variou significativamente entre as concentrações de extrato bruto (Fig. AIII-6A-E). No Capítulo II foram apresentados os gráficos da porcentagem de atividade antioxidante da concentração $13,3 \mathrm{mg} \cdot \mathrm{mL}^{-1}$, pois foi a maior concentração testada e a sua equivalência em concentração do padrão ácido gálico.

Os resultados aqui expostos demonstram a necessidade de testar-se concentrações maiores de extrato metanólico bruto de $P$. capillacea para avaliar o potencial antioxidante mediante o ensaio da atividade quelante de metais. 

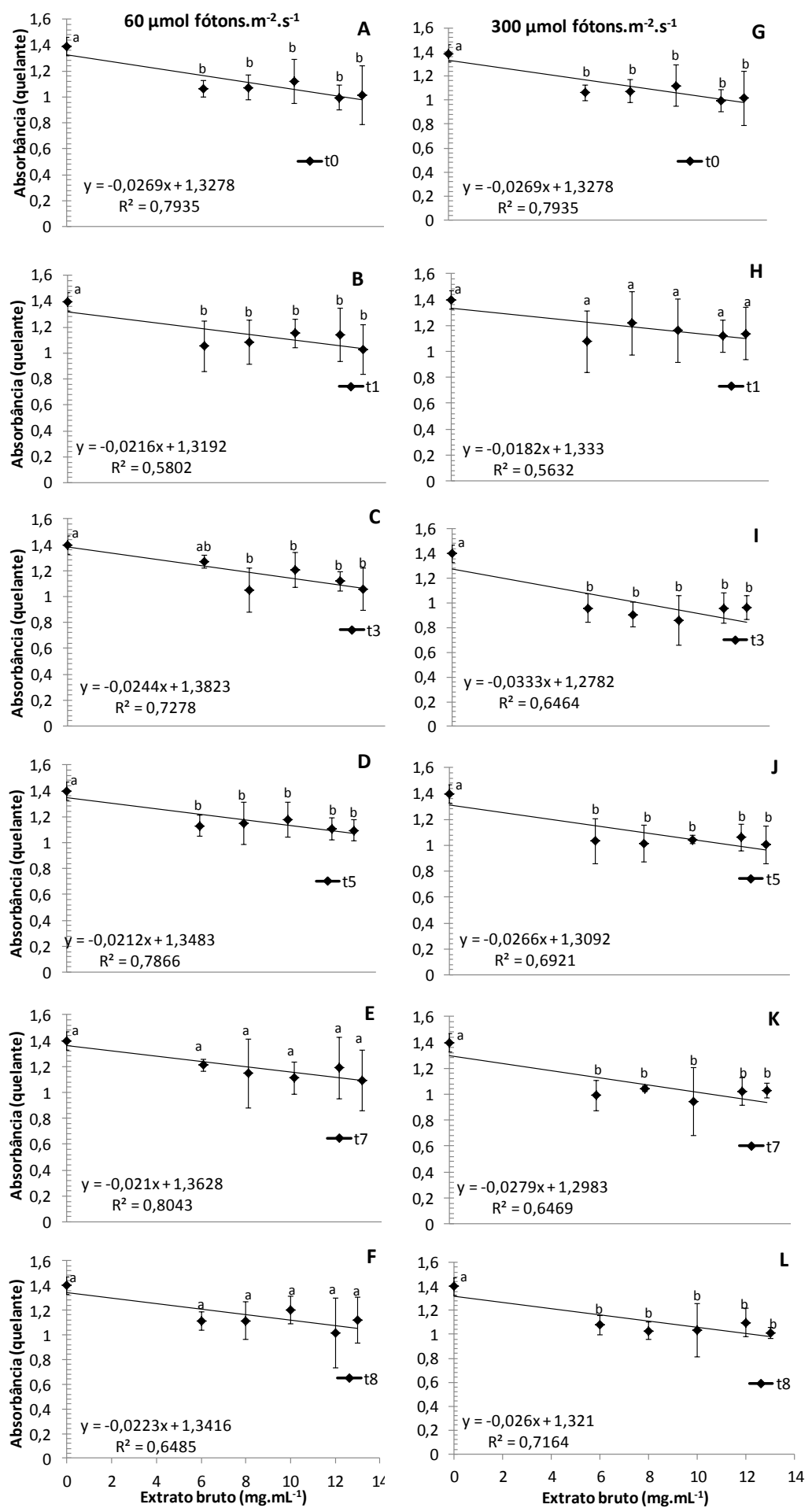

Anexo III - Figura 5. Curva de dose-resposta (concentração de extrato bruto: 0, 6, 8, 10, 12 e 13,3 mg. $\mathrm{mL}^{-1}$ versus a absorbância da reação) para $P$. capillacea estimada para cada um dos tempos de exposição sob as irradiâncias de $60 \mu \mathrm{mol}$ fótons. ${ }^{-2} \mathrm{~s}^{-1}$ (A-F) e $300 \mu$ mol fótons.m ${ }^{-}$ ${ }^{2} \cdot \mathrm{s}^{-1}$ (G-L) para o ensaio quelante de metais. Letras diferentes indicam diferença significativa $(\mathrm{p}<0,05)$, após a ANOVA e teste post-hoc de Newman-Keuls. 

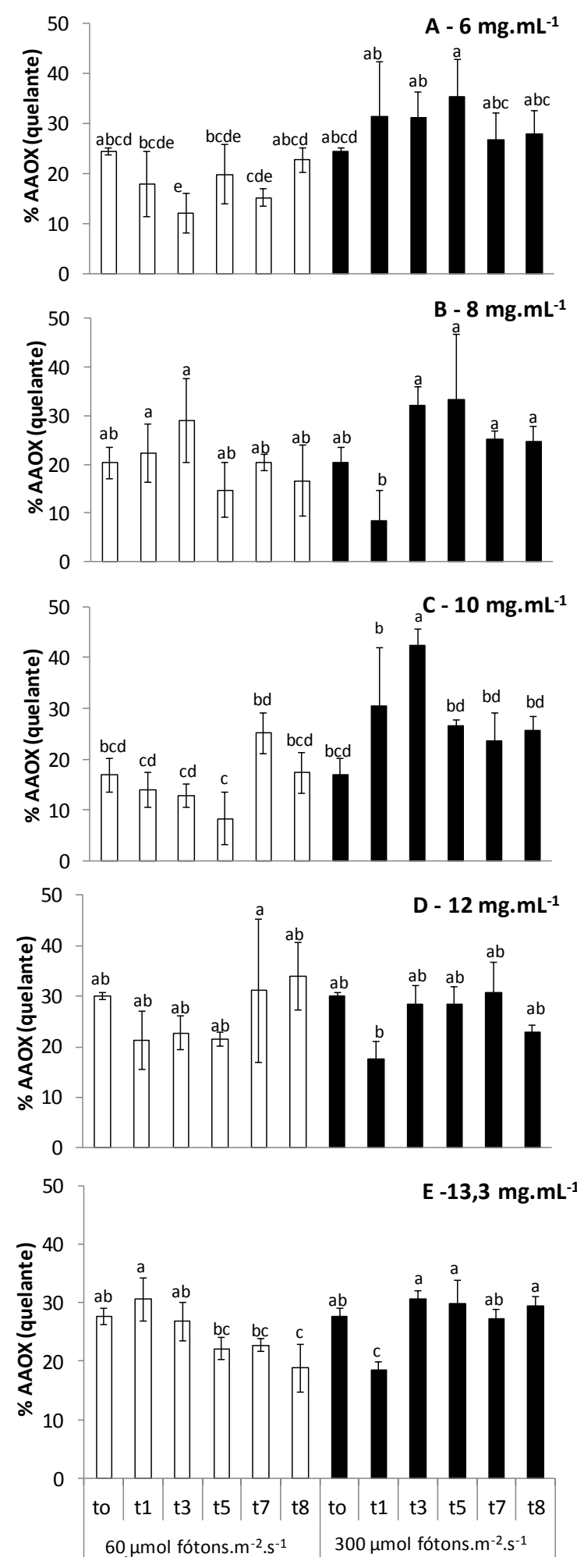

Anexo III - Figura 6. Atividade antioxidante percentual para cada uma das concentrações de extrato bruto de $P$. capillacea $\left(0,6,8,10,12\right.$ e 13,3 mg.mL $\left.\mathrm{mL}^{-1}\right)$ ao longo do tempo de exposição às irradiâncias de $60 \mu \mathrm{mol}$ fótons. $\mathrm{m}^{-2} \cdot \mathrm{s}^{-1}$ e $300 \mu \mathrm{mol}$ fótons. $\mathrm{m}^{-2} . \mathrm{s}^{-1}$ para o ensaio quelante de metais. Letras diferentes indicam diferença significativa $(\mathrm{p}<0,05)$, após a ANOVA e teste post-hoc de Newman-Keuls. 


\section{Capacidade antioxidante pelo método do Folin-Ciocalteu}

A Figura AIII-7 apresenta as curvas de dose-resposta em relação à concentração de extrato bruto algal e absorbância da reação para as irradiâncias de $60 \mu \mathrm{mol}$ fótons.m $\mathrm{m}^{-2} \cdot \mathrm{s}^{-1}$ (Fig. AIII-7A-F) e $300 \mu \mathrm{mol}$ fótons.m ${ }^{-2} \cdot \mathrm{s}^{-1}$ (Fig. AIII-7G-L) para o ensaio do Folin-Ciocalteu. É possível observar uma tendência de estabilização em quase todos os tempos entre as concentrações $8,10,12$ e $13,3 \mathrm{mg} \cdot \mathrm{mL}^{-1}$.

A atividade antioxidante não variou significativamente entre as concentrações de extrato bruto (Fig. AIII-8A-E).

Sendo assim, no Capítulo II foram apresentados os valores de porcentagem de atividade antioxidante, sua equivalência em concentração dos padrões ácido gálico e Trolox com base na concentração de extrato bruto algáceo de $6 \mathrm{mg} \cdot \mathrm{mL}^{-1}$ e cálculos de EC50. 

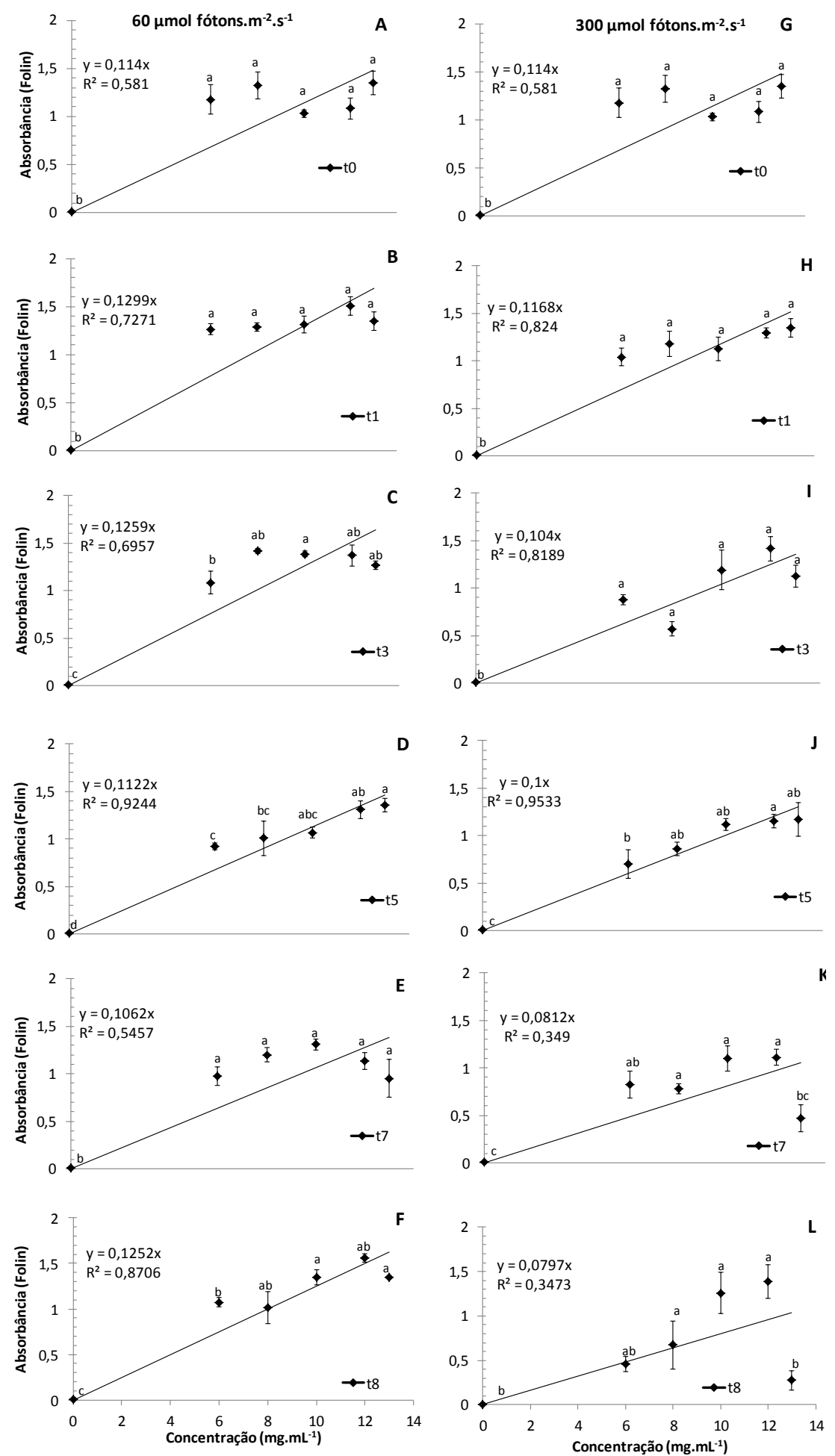

Anexo III - Figura 7. Curva de dose-resposta (concentração de extrato bruto: 0, 6, 8, 10, 12 e $13,3 \mathrm{mg} \cdot \mathrm{mL}^{-1}$ versus a absorbância da reação) para $P$. capillacea estimada para cada um dos tempos de exposição sob as irradiâncias de $60 \mu \mathrm{mol}$ fótons. ${ }^{-2} \cdot \mathrm{s}^{-1}$ (A-F) e $300 \mu$ mol fótons.m ${ }^{-}$ ${ }^{2} \cdot \mathrm{s}^{-1}$ (G-L) para o ensaio Folin-Ciocalteu. Letras diferentes indicam diferença significativa ( $\mathrm{p}$ $<0,05)$, após a ANOVA e teste post-hoc de Newman-Keuls. 


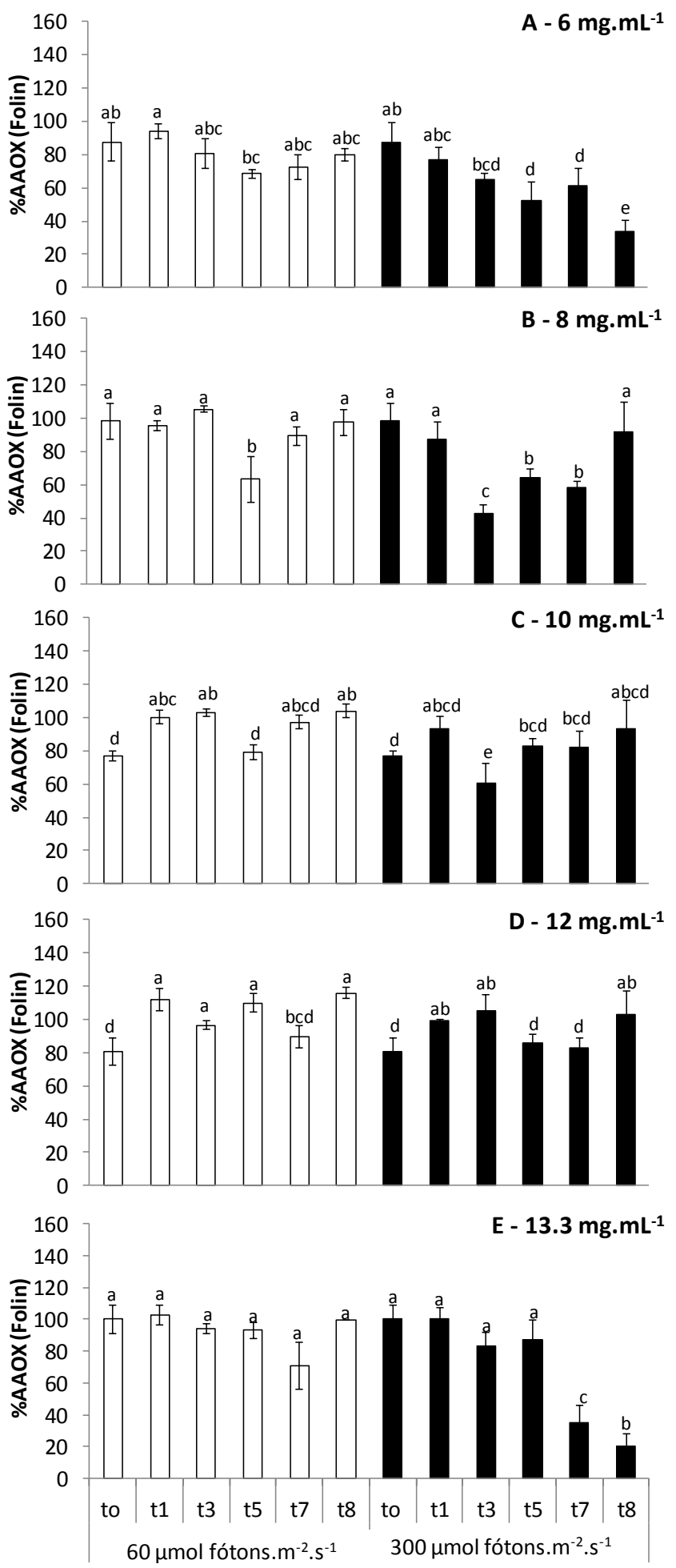

Anexo III - Figura 8. Atividade antioxidante percentual para cada uma das concentrações de extrato bruto de $P$. capillacea $\left(0,6,8,10,12\right.$ e 13,3 mg. $\left.\mathrm{mL}^{-1}\right)$ ao longo do tempo de exposição às irradiâncias de $60 \mu \mathrm{mol}$ fótons. $\mathrm{m}^{-2} \cdot \mathrm{s}^{-1}$ e $300 \mu \mathrm{mol}$ fótons. $\mathrm{m}^{-2} . \mathrm{s}^{-1}$ para o ensaio Folin-Ciocalteu. Letras diferentes indicam diferença significativa ( $p<0,05)$, após a ANOVA e teste post-hoc de Newman-Keuls. 


\section{Poder de redução do ferro (FRAP)}

A Figura AIII-9 apresenta as curvas de dose-resposta em relação à concentração de extrato bruto algal e absorbância da reação para as irradiâncias de $60 \mu \mathrm{mol}$ fótons. $\mathrm{m}^{-2} \cdot \mathrm{s}^{-1}$ (Fig. AIII-9A-F) e $300 \mu \mathrm{mol}$ fótons. $\mathrm{m}^{-2} . \mathrm{s}^{-1}$ (Fig. AIII-9G-L) para o ensaio do FRAP. Foi observada uma tendência de estabilidade na atividade antioxidante nas concentrações 12 e 13,3 mg.mL $\mathrm{mL}^{-1}$.

A atividade antioxidante não variou significativamente entre as concentrações de extrato bruto (Fig. AIII-10A-E).

Sendo assim, no Capítulo II foram apresentados os valores de porcentagem de atividade antioxidante, sua equivalência em concentração dos padrões ácido gálico e Trolox com base na concentração de extrato bruto algáceo de 13,3 mg.mL ${ }^{-1}$ e cálculos de EC50. 

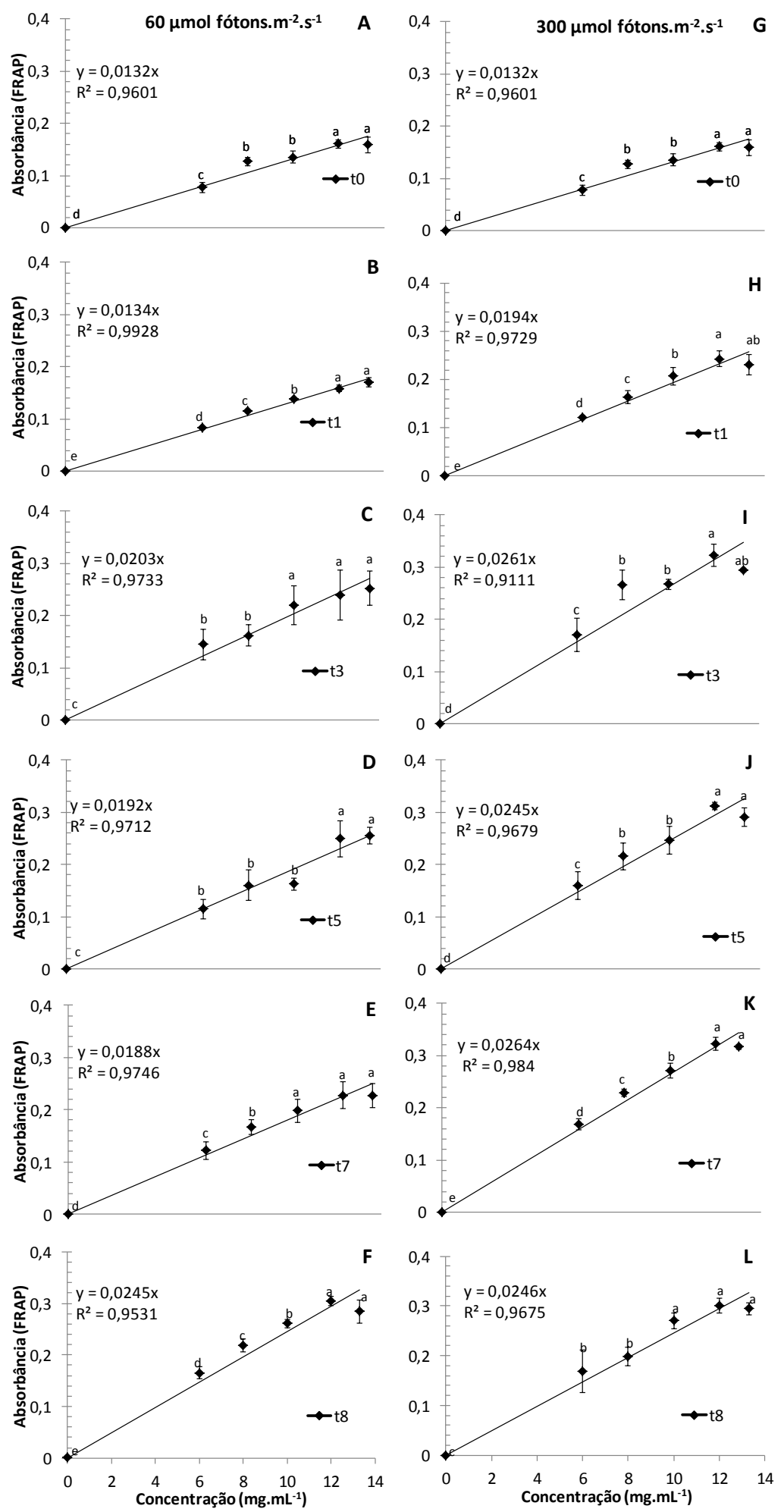

Anexo III - Figura 9. Curva de dose-resposta (concentração de extrato bruto: 0, 6, 8, 10, 12 e $13,3 \mathrm{mg} \cdot \mathrm{mL}^{-1}$ versus a absorbância da reação) para $P$. capillacea estimada para cada um dos tempos de exposição sob as irradiâncias de $60 \mu \mathrm{mol}$ fótons. $\mathrm{m}^{-2} \cdot \mathrm{s}^{-1}$ (A-F) e $300 \mu \mathrm{mol}$ fótons.m ${ }^{-}$ ${ }^{2} \cdot \mathrm{s}^{-1}$ (G-L) para o ensaio do FRAP. Letras diferentes indicam diferença significativa ( $<$ < 0,05), após a ANOVA e teste post-hoc de Newman-Keuls. 

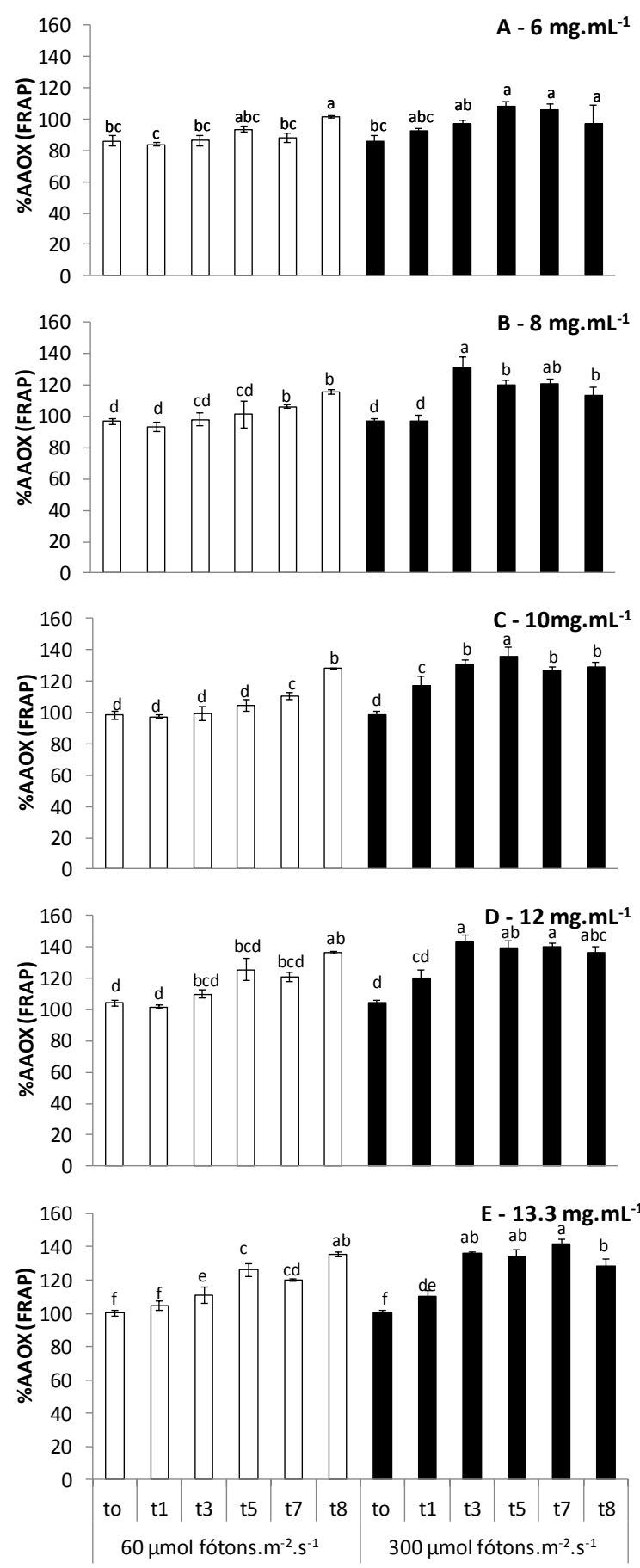

Anexo III - Figura 10. Atividade antioxidante percentual para cada uma das concentrações de extrato bruto de $P$. capillacea $\left(0,6,8,10,12\right.$ e 13,3 $\left.\mathrm{mg}^{-\mathrm{mL}^{-1}}\right)$ ao longo do tempo de exposição às irradiâncias de $60 \mu \mathrm{mol}$ fótons. $\mathrm{m}^{-2} . \mathrm{s}^{-1} \mathrm{e} 300 \mu \mathrm{mol}$ fótons. $\mathrm{m}^{-2} \cdot \mathrm{s}^{-1}$ para o ensaio do FRAP. Letras diferentes indicam diferença significativa $(\mathrm{p}<0,05)$, após a ANOVA e teste post-hoc de Newman-Keuls. 
Anexo III - Tabela 7. Tabelas de significância de ANOVA e teste post hoc de NewmanKeuls para atividade antioxidante para (A) DPPH, (B) ABTS e (C) quelante de metais.

\begin{tabular}{|c|c|c|c|c|c|c|c|c|c|c|c|c|c|}
\hline \multicolumn{14}{|c|}{ A - \% DPPH 13,3 mg.mL $\mathrm{L}^{-1}$} \\
\hline ANOVA & Soma dos & Grau de & Média & $\mathbf{F}$ & $\mathbf{p}$ & & & & & & & & \\
\hline Intercepto & 0,107458 & 1 & 0,107458 & 4261,684 & 0,000000 & & & & & & & & \\
\hline Irradiância & 0,000325 & 1 & 0,000325 & 12,898 & 0,001158 & & & & & & & & \\
\hline Tempo & 0,001662 & 5 & 0,000332 & 13,179 & 0,000001 & & & & & & & & \\
\hline Irradiância*Tempo & 0,001898 & 5 & 0,000380 & 15,057 & 0,000000 & & & & & & & & \\
\hline Erro & 0,000756 & 30 & 0,000025 & & & & & & & & & & \\
\hline \multicolumn{14}{|l|}{ Newman-Keuls } \\
\hline Tempo & Irradiância & to -60 & to -300 & $t 1-60$ & $t 3-60$ & t5 - 60 & t7 - 60 & t8 -60 & $\mathbf{t 1}-300$ & t3 -300 & t5 -300 & t7 - 300 & t8 -300 \\
\hline to & 60 & & 0,219355 & 0,109577 & 0,535693 & 0,000194 & 0,002223 & 0,000188 & 0,000170 & 0,260569 & 0,428892 & 0,196698 & 0,024400 \\
\hline to & 300 & & 0,219355 & 0,109577 & 0,535693 & 0,000194 & 0,002223 & 0,000188 & 0,000170 & 0,260569 & 0,428892 & 0,196698 & 0,024400 \\
\hline $\mathrm{t} 1$ & 60 & 0,219355 & & 0,006955 & 0,455612 & 0,001788 & 0,089697 & 0,005597 & 0,001999 & 0,805188 & 0,717913 & 0,958803 & 0,260454 \\
\hline $\mathrm{t} 3$ & 60 & 0,109577 & 0,006955 & & 0,074873 & 0,000137 & 0,000169 & 0,000163 & 0,000189 & 0,009853 & 0,032560 & 0,007489 & 0,000517 \\
\hline t5 & 60 & 0,535693 & 0,455612 & 0,074873 & & 0,000195 & 0,008706 & 0,000351 & 0,000195 & 0,485245 & 0,532114 & 0,347585 & 0,078783 \\
\hline $\mathrm{t} 7$ & 60 & 0,000194 & 0,001788 & 0,000137 & 0,000195 & & 0,148317 & 0,733685 & 0,860433 & 0,001286 & 0,000330 & 0,001512 & 0,023041 \\
\hline t8 & 60 & 0,002223 & 0,089697 & 0,000169 & 0,008706 & 0,148317 & & 0,160554 & 0,125888 & 0,091631 & 0,031276 & 0,126081 & 0,306321 \\
\hline $\mathrm{t} 1$ & 300 & 0,000170 & 0,001999 & 0,000189 & 0,000195 & 0,860433 & 0,125888 & 0,568739 & & 0,001495 & 0,000388 & 0,001859 & 0,022983 \\
\hline t3 & 300 & 0,260569 & 0,805188 & 0,009853 & 0,485245 & 0,001286 & 0,091631 & 0,004627 & 0,001495 & & 0,701232 & 0,978121 & 0,355677 \\
\hline t5 & 300 & 0,428892 & 0,717913 & 0,032560 & 0,532114 & 0,000330 & 0,031276 & 0,001130 & 0,000388 & 0,701232 & & 0,441641 & 0,205899 \\
\hline t7 & 300 & 0,196698 & 0,958803 & 0,007489 & 0,347585 & 0,001512 & 0,126081 & 0,006096 & 0,001859 & 0,978121 & 0,441641 & & 0,494812 \\
\hline t8 & 300 & 0,024400 & 0,260454 & 0,000517 & 0,078783 & 0,023041 & 0,306321 & 0,048483 & 0,022983 & 0,355677 & 0,205899 & 0,494812 & \\
\hline
\end{tabular}

\begin{tabular}{|c|c|c|c|c|c|c|c|c|c|c|c|c|c|}
\hline \multicolumn{14}{|c|}{ B - \% ABTS 12 mg.mL L $^{-1}$} \\
\hline ANOVA & Soma dos & Grau de & Média & $\mathbf{F}$ & p & & & & & & & & \\
\hline Intercepto & 0,271109 & 1 & 0,271109 & 39323,51 & 0,000000 & & & & & & & & \\
\hline Irradiância & 0,000005 & 1 & 0,000005 & 0,69 & 0,414521 & & & & & & & & \\
\hline Tempo & 0,000263 & 5 & 0,000053 & 7,63 & 0,000112 & & & & & & & & \\
\hline Irradiância*Tempo & 0,000654 & 5 & 0,000131 & 18,98 & 0,000000 & & & & & & & & \\
\hline Erro & 0,000200 & 29 & 0,000007 & & & & & & & & & & \\
\hline \multicolumn{14}{|l|}{ Newman-Keuls } \\
\hline Tempo & Irradiância & to -60 & to -300 & t1 - 60 & t3 -60 & t5 - 60 & t7 - 60 & t8 -60 & $\mathbf{t 1}-300$ & $t 3-300$ & t5 -300 & t7 -300 & t8 -300 \\
\hline to & 60 & & 0,627858 & 0,044229 & 0,001863 & 0,001373 & 0,000191 & 0,001564 & 0,029224 & 0,000212 & 0,704995 & 0,392773 & 0,021539 \\
\hline to & 300 & & 0,627858 & 0,044229 & 0,001863 & 0,001373 & 0,000191 & 0,001564 & 0,029224 & 0,000212 & 0,704995 & 0,392773 & 0,021539 \\
\hline $\mathrm{t} 1$ & 60 & 0,627858 & & 0,073277 & 0,005205 & 0,003506 & 0,000166 & 0,004206 & 0,064476 & 0,000315 & 0,661602 & 0,410339 & 0,044178 \\
\hline t3 & 60 & 0,044229 & 0,073277 & & 0,422594 & 0,273145 & 0,001046 & 0,346208 & 0,871064 & 0,044482 & 0,027828 & 0,156614 & 0,627496 \\
\hline t5 & 60 & 0,001863 & 0,005205 & 0,422594 & & 0,998504 & 0,017447 & 0,990704 & 0,510858 & 0,198341 & 0,000888 & 0,032323 & 0,627057 \\
\hline t7 & 60 & 0,001373 & 0,003506 & 0,273145 & 0,998504 & & 0,041959 & 0,967280 & 0,189370 & 0,527522 & 0,000689 & 0,020047 & 0,377012 \\
\hline t8 & 60 & 0,000191 & 0,000166 & 0,001046 & 0,017447 & 0,041959 & & 0,030462 & 0,002143 & 0,117226 & 0,000139 & 0,000167 & 0,002783 \\
\hline $\mathrm{t} 1$ & 300 & 0,029224 & 0,064476 & 0,871064 & 0,510858 & 0,189370 & 0,002143 & 0,361353 & & 0,076199 & 0,015303 & 0,227693 & 0,991244 \\
\hline t3 & 300 & 0,000212 & 0,000315 & 0,044482 & 0,198341 & 0,527522 & 0,117226 & 0,391216 & 0,076199 & & 0,000208 & 0,001553 & 0,100519 \\
\hline t5 & 300 & 0,704995 & 0,661602 & 0,027828 & 0,000888 & 0,000689 & 0,000139 & 0,000762 & 0,015303 & 0,000208 & & 0,337883 & 0,011887 \\
\hline t7 & 300 & 0,392773 & 0,410339 & 0,156614 & 0,032323 & 0,020047 & 0,000167 & 0,025342 & 0,227693 & 0,001553 & 0,337883 & & 0,144328 \\
\hline t8 & 300 & 0,021539 & 0,044178 & 0,627496 & 0,627057 & 0,377012 & 0,002783 & 0,511274 & 0,991244 & 0,100519 & 0,011887 & 0,144328 & \\
\hline
\end{tabular}

\begin{tabular}{|c|c|c|c|c|c|c|c|c|c|c|c|c|c|}
\hline \multicolumn{14}{|c|}{ C - \% Quelante $13,3 \mathrm{mg} \cdot \mathrm{mL}^{-1}$} \\
\hline ANOVA & $\begin{array}{l}\text { Soma dos } \\
\text { quadrados }\end{array}$ & $\begin{array}{l}\text { Grau de } \\
\text { liberdade }\end{array}$ & $\begin{array}{c}\text { Média } \\
\text { quadrada }\end{array}$ & $\mathbf{F}$ & p & & & & & & & & \\
\hline Intercepto & 0,085925 & 1 & 0,085925 & 12292,02 & 0,000000 & & & & & & & & \\
\hline Irradiância & 0,000053 & 1 & 0,000053 & 7,57 & 0,010884 & & & & & & & & \\
\hline Tempo & 0,000867 & 5 & 0,000173 & 24,82 & 0,000000 & & & & & & & & \\
\hline Irradiância*Tempo & 0,001745 & 5 & 0,000349 & 49,91 & 0,000000 & & & & & & & & \\
\hline Erro & 0,000175 & 25 & 0,000007 & & & & & & & & & & \\
\hline \multicolumn{14}{|l|}{ Newman-Keuls } \\
\hline Tempo & Irradiância & to -60 & to -300 & t1 -60 & $t 3-60$ & t5 - 60 & t7 - 60 & $18-60$ & $\mathbf{t 1}-300$ & $t 3-300$ & t5 -300 & t7-300 & t8 - 300 \\
\hline to & 60 & & 0,601172 & 0,918170 & 0,104901 & 0,132392 & 0,002706 & 0,000145 & 0,002373 & 0,662625 & 0,615512 & 0,873473 & 0,434746 \\
\hline to & 300 & & 0,601172 & 0,918170 & 0,104901 & 0,132392 & 0,002706 & 0,000145 & 0,002373 & 0,662625 & 0,615512 & 0,873473 & 0,434746 \\
\hline t1 & 60 & 0,601172 & & 0,577734 & 0,014955 & 0,024386 & 0,000371 & 0,000191 & 0,000331 & 0,920949 & 0,764483 & 0,625719 & 0,891665 \\
\hline t3 & 60 & 0,918170 & 0,577734 & & 0,093316 & 0,072533 & 0,003195 & 0,000135 & 0,003249 & 0,593515 & 0,668049 & 0,817466 & 0,639557 \\
\hline t5 & 60 & 0,104901 & 0,014955 & 0,093316 & & 0,758936 & 0,093072 & 0,000166 & 0,153326 & 0,014471 & 0,023977 & 0,099222 & 0,026066 \\
\hline t7 & 60 & 0,132392 & 0,024386 & 0,072533 & 0,758936 & & 0,119602 & 0,000130 & 0,141926 & 0,024343 & 0,037066 & 0,108349 & 0,037893 \\
\hline t8 & 60 & 0,002706 & 0,000371 & 0,003195 & 0,093072 & 0,119602 & & 0,000132 & 0,861930 & 0,000369 & 0,000541 & 0,002832 & 0,000607 \\
\hline t1 & 300 & 0,002373 & 0,000331 & 0,003249 & 0,153326 & 0,141926 & 0,861930 & 0,000149 & & 0,000344 & 0,000459 & 0,002611 & 0,000520 \\
\hline t3 & 300 & 0,662625 & 0,920949 & 0,593515 & 0,014471 & 0,024343 & 0,000369 & 0,000140 & 0,000344 & & 0,914577 & 0,659603 & 0,943632 \\
\hline t5 & 300 & 0,615512 & 0,764483 & 0,668049 & 0,023977 & 0,037066 & 0,000541 & 0,000165 & 0,000459 & 0,914577 & & 0,687268 & 0,878724 \\
\hline t7 & 300 & 0,873473 & 0,625719 & 0,817466 & 0,099222 & 0,108349 & 0,002832 & 0,000142 & 0,002611 & 0,659603 & 0,687268 & & 0,611357 \\
\hline t8 & 300 & 0,434746 & 0,891665 & 0,639557 & 0,026066 & 0,037893 & 0,000607 & 0,000153 & 0,000520 & 0,943632 & 0,878724 & 0,611357 & \\
\hline
\end{tabular}


Anexo III - Tabela 8. Tabelas de significância de ANOVA e teste post hoc de NewmanKeuls para porcentagem de atividade antioxidante para (A) Folin-Ciocaleu e (B) FRAP.

\begin{tabular}{|c|c|c|c|c|c|c|c|c|c|c|c|c|c|}
\hline \multicolumn{14}{|c|}{ A - \% Folin $6 \mathrm{mg} \cdot \mathrm{mL}^{-1}$} \\
\hline ANOVA & $\begin{array}{l}\text { Soma dos } \\
\text { quadrados }\end{array}$ & $\begin{array}{l}\text { Grau de } \\
\text { liberdade }\end{array}$ & $\begin{array}{c}\text { Média } \\
\text { quadrada }\end{array}$ & $\mathbf{F}$ & $\mathbf{p}$ & & & & & & & & \\
\hline Intercepto & 0,877453 & 1 & 0,877453 & 5331,581 & 0,000000 & & & & & & & & \\
\hline Irradiância & 0,008507 & 1 & 0,008507 & 51,690 & 0,000000 & & & & & & & & \\
\hline Tempo & 0,014508 & 5 & 0,002902 & 17,631 & 0,000000 & & & & & & & & \\
\hline Irradiância*Tempo & 0,007263 & 5 & 0,001453 & 8,826 & 0,000073 & & & & & & & & \\
\hline Erro & 0,003950 & 24 & 0,000165 & & & & & & & & & & \\
\hline \multicolumn{14}{|l|}{ Newman-Keuls } \\
\hline Tempo & Irradiância & to -60 & to -300 & $t 1-60$ & $t 3-60$ & t5 -60 & t7- 60 & t8 -60 & t1 -300 & $t 3-300$ & t5 -300 & t7 -300 & t8 -300 \\
\hline to & 60 & & 0,676638 & 0,382938 & 0,140410 & 0,285975 & 0,595039 & 0,934257 & 0,544804 & 0,060894 & 0,000522 & 0,017068 & 0,000168 \\
\hline to & 300 & & 0,676638 & 0,382938 & 0,140410 & 0,285975 & 0,595039 & 0,934257 & 0,544804 & 0,060894 & 0,000522 & 0,017068 & 0,000168 \\
\hline $\mathrm{t} 1$ & 60 & 0,676638 & & 0,326753 & 0,038523 & 0,101261 & 0,379807 & 0,451332 & 0,276898 & 0,013925 & 0,000250 & 0,003453 & 0,000143 \\
\hline $\mathrm{t} 3$ & 60 & 0,382938 & 0,326753 & & 0,456298 & 0,673090 & 0,926807 & 0,600870 & 0,892491 & 0,261104 & 0,002919 & 0,094888 & 0,000160 \\
\hline t5 & 60 & 0,140410 & 0,038523 & 0,456298 & & 0,580497 & 0,397116 & 0,150578 & 0,442956 & 0,596568 & 0,040901 & 0,458668 & 0,000127 \\
\hline t7 & 60 & 0,285975 & 5 0,101261 & 0,673090 & 0,580497 & & 0,559328 & 0,317627 & 0,504466 & 0,525121 & 0,017709 & 0,311313 & 0,000138 \\
\hline t8 & 60 & 0,595039 & 0,379807 & 0,926807 & 0,397116 & 0,559328 & & 0,713284 & 0,720230 & 0,237540 & 0,002860 & 0,089879 & 0,000147 \\
\hline $\mathrm{t} 1$ & 300 & 0,544804 & $+0,276898$ & 0,892491 & 0,442956 & 0,504466 & 0,720230 & 0,616415 & & 0,309460 & 0,005065 & 0,136715 & 0,000145 \\
\hline $\mathrm{t} 3$ & 300 & 0,060894 & $+0,013925$ & 0,261104 & 0,596568 & 0,525121 & 0,237540 & 0,063159 & 0,309460 & & 0,072758 & 0,506939 & 0,000172 \\
\hline t5 & 300 & 0,000522 & 0,000250 & 0,002919 & 0,040901 & 0,017709 & 0,002860 & 0,000525 & 0,005065 & 0,072758 & & 0,113718 & 0,000459 \\
\hline $\mathrm{t} 7$ & 300 & 0,017068 & 0,003453 & 0,094888 & 0,458668 & 0,311313 & 0,089879 & 0,017214 & 0,136715 & 0,506939 & 0,113718 & & 0,000139 \\
\hline t8 & 300 & 0,000168 & 3 0,000143 & 0,000160 & 0,000127 & 0,000138 & 0,000147 & 0,000194 & 0,000145 & 0,000172 & 0,000459 & 0,000139 & \\
\hline \multicolumn{14}{|c|}{ B - \% FRAP 12 mg.mL ${ }^{-1}$} \\
\hline ANOVA & $\begin{array}{l}\text { Soma dos } \\
\text { quadrados }\end{array}$ & $\begin{array}{c}\text { Grau de } \\
\text { liberdade }\end{array}$ & $\begin{array}{c}\text { Média } \\
\text { quadrada }\end{array}$ & $\mathbf{F}$ & p & & & & & & & & \\
\hline Intercepto & 43,84155 & 1 & 43,84155 & 12555,60 & 0,000000 & & & & & & & & \\
\hline Irradiância & 0,11004 & 1 & 0,11004 & 31,51 & 0,000001 & & & & & & & & \\
\hline Tempo & 0,17176 & 5 & 0,03435 & 9,84 & 0,000002 & & & & & & & & \\
\hline Irradiância*Tempo & 0,05986 & 5 & 0,01197 & 3,43 & 0,010240 & & & & & & & & \\
\hline Erro & 0,16062 & 46 & 0,00349 & & & & & & & & & & \\
\hline \multicolumn{14}{|l|}{ Newman-Keuls } \\
\hline Tempo & Irradiância & to -60 & to -300 & $t 1-60$ & t3 -60 & t5 - 60 & t7 - 60 & t8 -60 & t1 -300 & t3 -300 & t5 -300 & t7 - 300 & t8 - 300 \\
\hline to & 60 & & 0,943934 & 0,083242 & 0,100798 & 0,075343 & 0,000234 & 0,006977 & 0,179468 & 0,000193 & 0,000358 & 0,000137 & 0,002216 \\
\hline to & 300 & & 0,943934 & 0,083242 & 0,100798 & 0,075343 & 0,000234 & 0,006977 & 0,179468 & 0,000193 & 0,000358 & 0,000137 & 0,002216 \\
\hline $\mathrm{t} 1$ & 60 & 0,943934 & & 0,056118 & 0,086854 & 0,059225 & 0,000229 & 0,006368 & 0,089784 & 0,000168 & 0,000352 & 0,000189 & 0,002136 \\
\hline t3 & 60 & 0,083242 & 2. 0,056118 & & 0,971476 & 0,825515 & 0,068748 & 0,522453 & 0,526659 & 0,021755 & 0,114946 & 0,017931 & 0,357743 \\
\hline $\mathrm{t} 5$ & 60 & 0,100798 & 0,086854 & 0,971476 & & 0,994042 & 0,066101 & 0,258848 & 0,821487 & 0,023774 & 0,094900 & 0,021306 & 0,246877 \\
\hline t7 & 60 & 0,075343 & 3 0,059225 & 0,825515 & 0,994042 & & 0,088782 & 0,488192 & 0,667996 & 0,030812 & 0,136463 & 0,026510 & 0,372635 \\
\hline t8 & 60 & 0,000234 & 0,000229 & 0,068748 & 0,066101 & 0,088782 & & 0,400930 & 0,016886 & 0,588396 & 0,736086 & 0,768939 & 0,519136 \\
\hline $\mathrm{t} 1$ & 300 & 0,179468 & 0,089784 & 0,526659 & 0,821487 & 0,667996 & 0,016886 & 0,277098 & & 0,004408 & 0,032814 & 0,003470 & 0,148564 \\
\hline t3 & 300 & 0,000193 & 30,000168 & 0,021755 & 0,023774 & 0,030812 & 0,588396 & 0,227969 & 0,004408 & & 0,652849 & 0,883329 & 0,364333 \\
\hline $\mathrm{t} 5$ & 300 & 0,000358 & 3. 0,000352 & 0,114946 & 0,094900 & 0,136463 & 0,736086 & 0,436781 & 0,032814 & 0,652849 & & 0,731716 & 0,450949 \\
\hline t7 & 300 & 0,000137 & 0,000189 & 0,017931 & 0,021306 & 0,026510 & 0,768939 & 0,226859 & 0,003470 & 0,883329 & 0,731716 & & 0,390245 \\
\hline t8 & 300 & 0,002216 & 0,002136 & 0,357743 & 0,246877 & 0,372635 & 0,519136 & 0,634738 & 0,148564 & 0,364333 & 0,450949 & 0,390245 & \\
\hline
\end{tabular}


Anexo III - Tabela 9. Tabelas de significância de ANOVA e teste post hoc de NewmanKeuls para equivalente padrão ácido gálico para (A) DPPH, (B) ABTS e (C) quelante de metais.

\begin{tabular}{|c|c|c|c|c|c|c|c|c|c|c|c|c|c|}
\hline \multicolumn{14}{|c|}{ A - Eq. Ác.gálico DPPH 13,3 mg.mL $\mathrm{mL}^{-1}$} \\
\hline ANOVA & $\begin{array}{l}\text { Soma dos } \\
\text { quadrados }\end{array}$ & $\begin{array}{c}\text { Grau de } \\
\text { liberdade }\end{array}$ & $\begin{array}{c}\text { Média } \\
\text { quadrada }\end{array}$ & $\mathbf{F}$ & $\mathbf{p}$ & & & & & & & & \\
\hline Intercepto & 0,108951 & 1 & 0,108951 & 249,6481 & 0,000000 & & & & & & & & \\
\hline Irradiância & 0,000492 & 1 & 0,000492 & 1,1279 & 0,297631 & & & & & & & & \\
\hline Tempo & 0,016850 & 5 & 0,003370 & 7,7221 & 0,000129 & & & & & & & & \\
\hline Irradiância*Tempo & 0,028237 & 5 & 0,005647 & 12,9406 & 0,000002 & & & & & & & & \\
\hline Erro & 0,011783 & 27 & 0,000436 & & & & & & & & & & \\
\hline \multicolumn{14}{|l|}{ Newman-Keuls } \\
\hline Tempo & Irradiância & to -60 & to -300 & t1 -60 & $\mathrm{t} 3-60$ & t5 - 60 & t7 - 60 & t8 -60 & $\mathrm{t} 1-300$ & $\mathrm{t} 3-300$ & t5 -300 & t7 -300 & t8 -300 \\
\hline to & 60 & & 0,630130 & 0,656679 & 0,815378 & 0,000270 & 0,001345 & 0,001014 & 0,000365 & 0,669256 & 0,771847 & 0,569239 & 0,178094 \\
\hline to & 300 & & 0,630130 & 0,656679 & 0,815378 & 0,000270 & 0,001345 & 0,001014 & 0,000365 & 0,669256 & 0,771847 & 0,569239 & 0,178094 \\
\hline $\mathrm{t} 1$ & 60 & 0,656679 & 0,934242 & & 0,722139 & 0,003070 & 0,009032 & 0,010122 & 0,003185 & 0,950707 & 0,872725 & 0,986115 & 0,317906 \\
\hline t3 & 60 & 0,815378 & 0,678876 & 0,722139 & & 0,000409 & 0,001936 & 0,001463 & 0,000442 & 0,689986 & 0,654131 & 0,542419 & 0,226830 \\
\hline $\mathrm{t} 5$ & 60 & 0,000270 & 0,003339 & 0,003070 & 0,000409 & & 0,749172 & 0,705346 & 0,879107 & 0,002475 & 0,000794 & 0,002781 & 0,026051 \\
\hline t7 & 60 & 0,001345 & 0,013445 & 0,009032 & 0,001936 & 0,749172 & & 0,842157 & 0,676358 & 0,012242 & 0,004622 & 0,015698 & 0,036133 \\
\hline t8 & 60 & 0,001014 & 0,012808 & 0,010122 & 0,001463 & 0,705346 & 0,842157 & & 0,522672 & 0,010566 & 0,003578 & 0,012756 & 0,058311 \\
\hline $\mathrm{t} 1$ & 300 & 0,000365 & 0,003664 & 0,003185 & 0,000442 & 0,879107 & 0,676358 & 0,522672 & & 0,002837 & 0,000928 & 0,003288 & 0,024385 \\
\hline t3 & 300 & 0,669256 & 0,827665 & 0,950707 & 0,689986 & 0,002475 & 0,012242 & 0,010566 & 0,002837 & & 0,793352 & 0,970352 & 0,557948 \\
\hline t5 & 300 & 0,771847 & 0,819631 & 0,872725 & 0,654131 & 0,000794 & 0,004622 & 0,003578 & 0,000928 & 0,793352 & & 0,544768 & 0,383229 \\
\hline t7 & 300 & 0,569239 & 0,964197 & 0,986115 & 0,542419 & 0,002781 & 0,015698 & 0,012756 & 0,003288 & 0,970352 & 0,544768 & & 0,658056 \\
\hline t8 & 300 & 0,178094 & 0,521624 & 0,317906 & 0,226830 & 0,026051 & 0,036133 & 0,058311 & 0,024385 & 0,557948 & 0,383229 & 0,658056 & \\
\hline \multicolumn{14}{|c|}{ B - Eq. Ác.gálico ABTS $12 \mathrm{mg} \mathrm{mL}^{-1}$} \\
\hline ANOVA & $\begin{array}{l}\text { Soma dos } \\
\text { quadrados }\end{array}$ & $\begin{array}{c}\text { Grau de } \\
\text { liberdade }\end{array}$ & $\begin{array}{c}\text { Média } \\
\text { quadrada }\end{array}$ & $\mathbf{F}$ & $\mathrm{p}$ & & & & & & & & \\
\hline Intercepto & 0,462129 & 1 & 0,462129 & 11114,30 & 0,000000 & & & & & & & & \\
\hline Irradiância & 0,000032 & 1 & 0,000032 & 0,77 & 0,387280 & & & & & & & & \\
\hline Tempo & 0,001675 & 5 & 0,000335 & 8,05 & 0,000073 & & & & & & & & \\
\hline Irradiância*Tempo & 0,004039 & 5 & 0,000808 & 19,43 & 0,000000 & & & & & & & & \\
\hline Erro & 0,001206 & 29 & 0,000042 & & & & & & & & & & \\
\hline \multicolumn{14}{|l|}{ Newman-Keuls } \\
\hline Tempo & Irradiância & to -60 & to -300 & $t 1-60$ & $\mathrm{t} 3-60$ & t5 -60 & $\mathrm{t} 7-60$ & t8 -60 & $\mathrm{t} 1-300$ & $\mathrm{t} 3-\mathbf{3 0 0}$ & t5 -300 & t7 -300 & t8 -300 \\
\hline to & 60 & & 0,645901 & 0,052706 & 0,001954 & 0,001431 & 0,000191 & 0,001610 & 0,024701 & 0,000202 & 0,732875 & 0,391154 & 0,034187 \\
\hline to & 300 & & 0,645901 & 0,052706 & 0,001954 & 0,001431 & 0,000191 & 0,001610 & 0,024701 & 0,000202 & 0,732875 & 0,391154 & 0,034187 \\
\hline $\mathrm{t} 1$ & 60 & 0,052706 & 0,081751 & & 0,389042 & 0,246982 & 0,000503 & 0,312726 & 0,612655 & 0,030734 & 0,036505 & 0,180467 & 0,865340 \\
\hline t3 & 60 & 0,001954 & 0,005123 & 0,389042 & & 0,998642 & 0,009142 & 0,996635 & 0,603478 & 0,167380 & 0,001012 & 0,034070 & 0,482471 \\
\hline t5 & 60 & 0,001431 & 0,003431 & 0,246982 & 0,998642 & & 0,022620 & 0,963177 & 0,356178 & 0,469333 & 0,000780 & 0,021039 & 0,173950 \\
\hline t7 & 60 & 0,000191 & 0,000165 & 0,000503 & 0,009142 & 0,022620 & & 0,016466 & 0,001309 & 0,085198 & 0,000139 & 0,000159 & 0,000994 \\
\hline t8 & 60 & 0,001610 & 0,004062 & 0,312726 & 0,996635 & 0,963177 & 0,016466 & & 0,484009 & 0,343683 & 0,000853 & 0,026261 & 0,333845 \\
\hline $\mathrm{t} 1$ & 300 & 0,024701 & 0,047458 & 0,612655 & 0,603478 & 0,356178 & 0,001309 & 0,484009 & & 0,075156 & 0,015053 & 0,161249 & 0,998686 \\
\hline t3 & 300 & 0,000202 & 0,000272 & 0,030734 & 0,167380 & 0,469333 & 0,085198 & 0,343683 & 0,075156 & & 0,000206 & 0,001284 & 0,055333 \\
\hline t5 & 300 & 0,732875 & 0,700450 & 0,036505 & 0,001012 & 0,000780 & 0,000139 & 0,000853 & 0,015053 & 0,000206 & & 0,355539 & 0,019770 \\
\hline t7 & 300 & 0,391154 & 0,394656 & 0,180467 & 0,034070 & 0,021039 & 0,000159 & 0,026261 & 0,161249 & 0,001284 & 0,355539 & & 0,255877 \\
\hline t8 & 300 & 0,034187 & 0,070519 & 0,865340 & 0,482471 & 0,173950 & 0,000994 & 0,333845 & 0,998686 & 0,055333 & 0,019770 & 0,255877 & \\
\hline
\end{tabular}

C - Eq. Ác.gálico Quelante $13,3 \mathrm{mg} \cdot \mathrm{mL}^{-1}$

\begin{tabular}{lrrrrr}
\multicolumn{1}{r}{ ANOVA } & $\begin{array}{c}\text { Soma dos } \\
\text { quadrados }\end{array}$ & $\begin{array}{c}\text { Grau de } \\
\text { liberdade }\end{array}$ & $\begin{array}{c}\text { Média } \\
\text { quadrada }\end{array}$ & F & p \\
Intercepto & 0,171027 & 1 & 0,171027 & 126,7525 & 0,000000 \\
Irradiância & 0,000674 & 1 & 0,000674 & 0,4997 & 0,487771 \\
Tempo & 0,014799 & 5 & 0,002960 & 2,1936 & 0,095583 \\
Irradiância*Tempo & 0,013240 & 5 & 0,002648 & 1,9625 & 0,128573 \\
Erro & 0,026986 & 20 & 0,001349 & &
\end{tabular}

\begin{tabular}{|c|c|c|c|c|c|c|c|c|c|c|c|c|c|}
\hline \multicolumn{14}{|c|}{ Newman-Keuls } \\
\hline Tempo & Irradiância & to -60 & to -300 & $t 1-60$ & t3 -60 & t5 -60 & t7- 60 & t8 - 60 & $t 1-300$ & $\mathrm{t} 3-\mathbf{3 0 0}$ & t5 -300 & t7 -300 & t8 - 300 \\
\hline to & 60 & & 0,676873 & 0,510320 & 0,958082 & 0,586172 & 0,083272 & 0,997762 & 0,699364 & 0,699792 & 0,674247 & 0,997924 & 0,636619 \\
\hline to & 300 & & 0,676873 & 0,510320 & 0,958082 & 0,586172 & 0,083272 & 0,997762 & 0,699364 & 0,699792 & 0,674247 & 0,997924 & 0,636619 \\
\hline $\mathrm{t} 1$ & 60 & 0,510320 & 0,923011 & & 0,752467 & 0,849188 & 0,236886 & 0,881744 & 0,945976 & 0,941410 & 0,889579 & 0,911339 & 0,808507 \\
\hline t3 & 60 & 0,958082 & 0,719660 & 0,752467 & & 0,648027 & 0,087505 & 0,991054 & 0,721138 & 0,730195 & 0,758989 & 0,991291 & 0,767962 \\
\hline t5 & 60 & 0,586172 & 0,996030 & 0,849188 & 0,648027 & & 0,441889 & 0,716005 & 0,997159 & 0,995351 & 0,732025 & 0,710685 & 0,840612 \\
\hline t7 & 60 & 0,083272 & 0,339875 & 0,236886 & 0,087505 & 0,441889 & & 0,097935 & 0,142810 & 0,255632 & 0,339673 & 0,088700 & 0,296243 \\
\hline t8 & 60 & 0,997762 & 0,772386 & 0,881744 & 0,991054 & 0,716005 & 0,097935 & & 0,759366 & 0,774216 & 0,832839 & 0,909612 & 0,860600 \\
\hline $\mathrm{t} 1$ & 300 & 0,699364 & 0,979532 & 0,945976 & 0,721138 & 0,997159 & 0,142810 & 0,759366 & & 0,916253 & 0,981148 & 0,734148 & 0,970682 \\
\hline t3 & 300 & 0,699792 & 0,931177 & 0,941410 & 0,730195 & 0,995351 & 0,255632 & 0,774216 & 0,916253 & & 0,970799 & 0,754677 & 0,963385 \\
\hline t5 & 300 & 0,674247 & 0,934075 & 0,889579 & 0,758989 & 0,732025 & 0,339673 & 0,832839 & 0,981148 & 0,970799 & & 0,838241 & 0,830881 \\
\hline t7 & 300 & 0,997924 & 0,759257 & 0,911339 & 0,991291 & 0,710685 & 0,088700 & 0,909612 & 0,734148 & 0,754677 & 0,838241 & & 0,877187 \\
\hline t8 & 300 & 0,636619 & 0,940186 & 0,808507 & 0,767962 & 0,840612 & 0,296243 & 0,860600 & 0,970682 & 0,963385 & 0,830881 & 0,877187 & \\
\hline
\end{tabular}


Anexo III - Tabela 10. Tabelas de significância de ANOVA e teste post hoc de NewmanKeuls para equivalente padrão ácido gálico para (A) Folin-Ciocalteu e (B) FRAP.

\begin{tabular}{|c|c|c|c|c|c|c|c|c|c|c|c|c|c|}
\hline \multicolumn{14}{|c|}{ A - Eq. Ác.gálico Folin $6 \mathrm{mg} \cdot \mathrm{mL}^{-1}$} \\
\hline ANOVA & $\begin{array}{l}\text { Soma dos } \\
\text { quadrados }\end{array}$ & $\begin{array}{l}\text { Grau de } \\
\text { liberdade }\end{array}$ & $\begin{array}{c}\text { Média } \\
\text { quadrada }\end{array}$ & $\mathbf{F}$ & $\mathbf{p}$ & & & & & & & & \\
\hline Intercepto & 192,9615 & 1 & 192,9615 & 3276,116 & 0,000000 & & & & & & & & \\
\hline Irradiância & 3,2917 & 1 & 3,2917 & 55,886 & 0,000000 & & & & & & & & \\
\hline Tempo & 4,6687 & 5 & 0,9337 & 15,853 & 0,000001 & & & & & & & & \\
\hline Irradiância*Tempo & 1,5619 & 5 & 0,3124 & 5,304 & 0,002020 & & & & & & & & \\
\hline Erro & 1,4136 & 24 & 0,0589 & & & & & & & & & & \\
\hline \multicolumn{14}{|l|}{ Newman-Keuls } \\
\hline Tempo & Irradiância & to -60 & to -300 & $\mathrm{t} 1-60$ & $\mathbf{t 1}-300$ & t3 -60 & $t 3-300$ & t5 -60 & t5 -300 & t7 -60 & t7 -300 & t8 -60 & t8 -300 \\
\hline to & 60 & & 0,296123 & 0,502317 & 0,061418 & 0,172377 & 0,586481 & 0,353841 & 0,457479 & 0,022035 & 0,000337 & 0,006352 & 0,000194 \\
\hline to & 300 & & 0,296123 & 0,502317 & 0,061418 & 0,172377 & 0,586481 & 0,353841 & 0,457479 & 0,022035 & 0,000337 & 0,006352 & 0,000194 \\
\hline $\mathrm{t} 1$ & 60 & 0,502317 & 0,150945 & & 0,305382 & 0,549803 & 0,889473 & 0,851280 & 0,844283 & 0,150354 & 0,002202 & 0,054817 & 0,000161 \\
\hline t3 & 60 & 0,061418 & 0,006854 & 0,305382 & & 0,525966 & 0,280278 & 0,287748 & 0,345065 & 0,576617 & 0,058088 & 0,471030 & 0,000186 \\
\hline $\mathrm{t} 5$ & 60 & 0,172377 & 0,024192 & 0,549803 & 0,525966 & & 0,467138 & 0,556470 & 0,443170 & 0,458998 & 0,021298 & 0,283238 & 0,000151 \\
\hline $\mathrm{t} 7$ & 60 & 0,586481 & 0,165811 & 0,889473 & 0,280278 & 0,467138 & & 0,941878 & 0,681392 & 0,148182 & 0,002406 & 0,057336 & 0,000148 \\
\hline t8 & 60 & 0,353841 & 0,130537 & 0,851280 & 0,287748 & 0,556470 & 0,941878 & & 0,877499 & 0,132047 & 0,001751 & 0,045272 & 0,000168 \\
\hline $\mathrm{t} 1$ & 300 & 0,457479 & 0,099645 & 0,844283 & 0,345065 & 0,443170 & 0,681392 & 0,877499 & & 0,219678 & 0,004813 & 0,099663 & 0,000146 \\
\hline t3 & 300 & 0,022035 & 0,002250 & 0,150354 & 0,576617 & 0,458998 & 0,148182 & 0,132047 & 0,219678 & & 0,106462 & 0,539422 & 0,000311 \\
\hline t5 & 300 & 0,000337 & 0,000205 & 0,002202 & 0,058088 & 0,021298 & 0,002406 & 0,001751 & 0,004813 & 0,106462 & & 0,146891 & 0,006226 \\
\hline $\mathrm{t} 7$ & 300 & 0,006352 & 0,000697 & 0,054817 & 0,471030 & 0,283238 & 0,057336 & 0,045272 & 0,099663 & 0,539422 & 0,146891 & & 0,000525 \\
\hline t8 & 300 & 0,000194 & 0,000143 & 0,000161 & 0,000186 & 0,000151 & 0,000148 & 0,000168 & 0,000146 & 0,000311 & 0,006226 & 0,000525 & \\
\hline
\end{tabular}

\begin{tabular}{lrrrrr} 
B - Eq. Ác.gálico FRAP & $\mathbf{1 2} \mathbf{~ m g . m L}^{-\mathbf{1}}$ & & & \\
\multicolumn{1}{c}{ ANOVA } & $\begin{array}{r}\text { Soma dos } \\
\text { quadrados }\end{array}$ & $\begin{array}{c}\text { Grau de } \\
\text { liberdade }\end{array}$ & $\begin{array}{c}\text { Média } \\
\text { quadrada }\end{array}$ & F & p \\
Intercepto & 0,397131 & 1 & 0,397131 & 35733,66 & 0,000000 \\
Irradiância & 0,001003 & 1 & 0,001003 & 90,28 & 0,000000 \\
Tempo & 0,002647 & 5 & 0,000529 & 47,64 & 0,000000 \\
Irradiância*Tempo & 0,000730 & 5 & 0,000146 & 13,13 & 0,000003 \\
Erro & 0,000278 & 25 & 0,000011 & &
\end{tabular}

\begin{tabular}{|c|c|c|c|c|c|c|c|c|c|c|c|c|c|}
\hline \multicolumn{14}{|l|}{ Newman-Keuls } \\
\hline Tempo & Irradiância & to -60 & to -300 & $t 1-60$ & $t 1-300$ & $t 3-60$ & t3 -300 & t5 - 60 & t5 -300 & t7 - 60 & t7 - 300 & t8 -60 & t8 -300 \\
\hline to & 60 & & 0,188617 & 0,006303 & 0,000142 & 0,000148 & 0,000165 & 0,000369 & 0,001236 & 0,000191 & 0,000153 & 0,000140 & 0,000145 \\
\hline to & 300 & & 0,188617 & 0,006303 & 0,000142 & 0,000148 & 0,000165 & 0,000369 & 0,001236 & 0,000191 & 0,000153 & 0,000140 & 0,000145 \\
\hline $\mathrm{t} 1$ & 60 & 0,006303 & 0,051435 & & 0,000676 & 0,036843 & 0,000145 & 0,212642 & 0,356187 & 0,000153 & 0,000143 & 0,000165 & 0,000224 \\
\hline $\mathrm{t} 3$ & 60 & 0,000142 & 0,000138 & 0,000676 & & 0,068559 & 0,034470 & 0,014004 & 0,003857 & 0,032453 & 0,060181 & 0,000586 & 0,413643 \\
\hline t5 & 60 & 0,000148 & 0,000513 & 0,036843 & 0,068559 & & 0,000637 & 0,258256 & 0,145647 & 0,000549 & 0,001326 & 0,000145 & 0,029432 \\
\hline t7 & 60 & 0,000165 & 0,000153 & 0,000145 & 0,034470 & 0,000637 & & 0,000166 & 0,000146 & 0,833669 & 0,609046 & 0,113753 & 0,112429 \\
\hline t8 & 60 & 0,000369 & 0,004614 & 0,212642 & 0,014004 & 0,258256 & 0,000166 & & 0,434854 & 0,000166 & 0,000223 & 0,000145 & 0,003524 \\
\hline $\mathrm{t} 1$ & 300 & 0,001236 & 0,016637 & 0,356187 & 0,003857 & 0,145647 & 0,000146 & 0,434854 & & 0,000148 & 0,000149 & 0,000153 & 0,000849 \\
\hline t3 & 300 & 0,000191 & 0,000165 & 0,000153 & 0,032453 & 0,000549 & 0,833669 & 0,000166 & 0,000148 & & 0,748015 & 0,073169 & 0,124611 \\
\hline t5 & 300 & 0,000153 & 0,000145 & 0,000143 & 0,060181 & 0,001326 & 0,609046 & 0,000223 & 0,000149 & 0,748015 & & 0,068594 & 0,128716 \\
\hline t7 & 300 & 0,000140 & 0,000191 & 0,000165 & 0,000586 & 0,000145 & 0,113753 & 0,000145 & 0,000153 & 0,073169 & 0,068594 & & 0,002784 \\
\hline t8 & 300 & 0,000145 & 0,000142 & 0,000224 & 0,413643 & 0,029432 & 0,112429 & 0,003524 & 0,000849 & 0,124611 & 0,128716 & 0,002784 & \\
\hline
\end{tabular}


Anexo III - Tabela 11. Tabelas de significância de ANOVA e teste post hoc de NewmanKeuls para porcentagem de atividade antioxidante dos extratos tamponados de pigmentos para (A) DPPH, (B) ABTS e (C) quelante de metais.

\begin{tabular}{|c|c|c|c|c|c|c|c|c|c|c|c|c|c|}
\hline \multicolumn{14}{|l|}{$A-\% D$} \\
\hline ANOVA & $\begin{array}{l}\text { Soma dos } \\
\text { quadrados }\end{array}$ & $\begin{array}{l}\text { Grau de } \\
\text { liberdade }\end{array}$ & $\begin{array}{c}\text { Média } \\
\text { quadrada }\end{array}$ & $F$ & $\mathbf{p}$ & & & & & & & & \\
\hline Intercepto & 0,047723 & 1 & 0,047723 & 5844,327 & 0,000000 & & & & & & & & \\
\hline Irradiância & 0,000000 & 1 & 0,000000 & 0,055 & 0,815936 & & & & & & & & \\
\hline Tempo & 0,000344 & 5 & 0,000069 & 8,414 & 0,000041 & & & & & & & & \\
\hline Irradiância*Tempo & 0,000213 & 5 & 0,000043 & 5,219 & 0,001371 & & & & & & & & \\
\hline Erro & 0,000253 & 31 & 0,000008 & & & & & & & & & & \\
\hline \multicolumn{14}{|l|}{ Newman-Keuls } \\
\hline Tempo & Irradiância & to -60 & to -300 & $t 1-60$ & $\mathrm{t} 3-60$ & t5 - 60 & $\mathrm{t} 7-60$ & t8 -60 & $\mathbf{t 1}-300$ & t3 -300 & t5 -300 & t7 -300 & t8 -300 \\
\hline to & 60 & & 0,951794 & 0,046946 & 0,822183 & 0,083823 & 0,001919 & 0,397279 & 0,245424 & 0,918185 & 0,906130 & 0,001832 & 0,265092 \\
\hline to & 300 & & 0,951794 & 0,046946 & 0,822183 & 0,083823 & 0,001919 & 0,397279 & 0,245424 & 0,918185 & 0,906130 & 0,001832 & 0,265092 \\
\hline $\mathrm{t} 1$ & 60 & 0,951794 & & 0,044579 & 0,702765 & 0,077444 & 0,001863 & 0,326434 & 0,211023 & 0,741321 & 0,982381 & 0,001795 & 0,239564 \\
\hline t3 & 60 & 0,046946 & 0,044579 & & 0,157810 & 0,734930 & 0,190871 & 0,528471 & 0,687023 & 0,076010 & 0,042153 & 0,340826 & 0,561732 \\
\hline t5 & 60 & 0,822183 & 0,702765 & 0,157810 & & 0,225638 & 0,009530 & 0,362796 & 0,362160 & 0,640438 & 0,859958 & 0,009689 & 0,474395 \\
\hline t7 & 60 & 0,083823 & 0,077444 & 0,734930 & 0,225638 & & 0,229099 & 0,615677 & 0,725827 & 0,122147 & 0,077675 & 0,308141 & 0,494318 \\
\hline t8 & 60 & 0,001919 & 0,001863 & 0,190871 & 0,009530 & 0,229099 & & 0,067028 & 0,129935 & 0,003573 & 0,001689 & 0,931004 & 0,104085 \\
\hline $\mathrm{t} 1$ & 300 & 0,245424 & 0,211023 & 0,687023 & 0,362160 & 0,725827 & 0,129935 & 0,649697 & & 0,268164 & 0,245935 & 0,145402 & 0,940712 \\
\hline t3 & 300 & 0,918185 & 0,741321 & 0,076010 & 0,640438 & 0,122147 & 0,003573 & 0,355488 & 0,268164 & & 0,955369 & 0,003522 & 0,323584 \\
\hline t5 & 300 & 0,906130 & 0,982381 & 0,042153 & 0,859958 & 0,077675 & 0,001689 & 0,415937 & 0,245935 & 0,955369 & & 0,001539 & 0,257126 \\
\hline t7 & 300 & 0,001832 & 0,001795 & 0,340826 & 0,009689 & 0,308141 & 0,931004 & 0,071292 & 0,145402 & 0,003522 & 0,001539 & & 0,126807 \\
\hline t8 & 300 & 0,265092 & 0,239564 & 0,561732 & 0,474395 & 0,494318 & 0,104085 & 0,855393 & 0,940712 & 0,323584 & 0,257126 & 0,126807 & \\
\hline \multicolumn{14}{|l|}{ B - \% ABTS Tampão } \\
\hline ANOVA & $\begin{array}{l}\text { Soma dos } \\
\text { quadrados }\end{array}$ & $\begin{array}{l}\text { Grau de } \\
\text { liberdade }\end{array}$ & $\begin{array}{c}\text { Média } \\
\text { quadrada }\end{array}$ & $\mathbf{F}$ & $\mathbf{p}$ & & & & & & & & \\
\hline Intercepto & 2,072311 & 1 & 2,072311 & 4249,600 & 0,000000 & & & & & & & & \\
\hline Irradiância & 0,000999 & 1 & 0,000999 & 2,049 & 0,163038 & & & & & & & & \\
\hline Tempo & 0,064104 & 5 & 0,012821 & 26,291 & 0,000000 & & & & & & & & \\
\hline Irradiância*Tempo & 0,009765 & 5 & 0,001953 & 4,005 & 0,006949 & & & & & & & & \\
\hline Erro & 0,014142 & 29 & 0,000488 & & & & & & & & & & \\
\hline \multicolumn{14}{|l|}{ Newman-Keuls } \\
\hline Tempo & Irradiância & to -60 & to -300 & $\mathrm{t} 1-60$ & $\mathrm{t} 3-60$ & t5 - 60 & $\mathrm{t} 7-60$ & t8 -60 & $\mathbf{t 1}-300$ & t3 -300 & t5 -300 & t7 -300 & t8 -300 \\
\hline to & 60 & & 0,000237 & 0,000191 & 0,000153 & 0,000149 & 0,006700 & 0,006946 & 0,001053 & 0,000149 & 0,000166 & 0,000139 & 0,024385 \\
\hline to & 300 & & 0,000237 & 0,000191 & 0,000153 & 0,000149 & 0,006700 & 0,006946 & 0,001053 & 0,000149 & 0,000166 & 0,000139 & 0,024385 \\
\hline$t 1$ & 60 & 0,000237 & & 0,336792 & 0,411835 & 0,314386 & 0,183727 & 0,171602 & 0,366261 & 0,490082 & 0,323162 & 0,030414 & 0,038153 \\
\hline t3 & 60 & 0,000191 & 0,336792 & & 0,877292 & 0,838080 & 0,007362 & 0,010652 & 0,075995 & 0,802947 & 0,902559 & 0,196244 & 0,000846 \\
\hline t5 & 60 & 0,000153 & 0,411835 & 0,877292 & & 0,850228 & 0,015950 & 0,021132 & 0,121709 & 0,681206 & 0,717857 & 0,288490 & 0,001869 \\
\hline $\mathrm{t} 7$ & 60 & 0,000149 & 0,314386 & 0,838080 & 0,850228 & & 0,031971 & 0,035777 & 0,145182 & 0,898236 & 0,800068 & 0,205123 & 0,004354 \\
\hline t8 & 60 & 0,006700 & 0,183727 & 0,007362 & 0,015950 & 0,031971 & & 0,820210 & 0,485226 & 0,032820 & 0,008159 & 0,000397 & 0,351319 \\
\hline $\mathrm{t} 1$ & 300 & 0,001053 & 0,366261 & 0,075995 & 0,121709 & 0,145182 & 0,485226 & 0,359180 & & 0,186458 & 0,077148 & 0,003948 & 0,174229 \\
\hline t3 & 300 & 0,000149 & 0,490082 & 0,802947 & 0,681206 & 0,898236 & 0,032820 & 0,040287 & 0,186458 & & 0,718030 & 0,198541 & 0,004182 \\
\hline t5 & 300 & 0,000166 & 0,323162 & 0,902559 & 0,717857 & 0,800068 & 0,008159 & 0,011413 & 0,077148 & 0,718030 & & 0,331033 & 0,000937 \\
\hline t7 & 300 & 0,000139 & 0,030414 & 0,196244 & 0,288490 & 0,205123 & 0,000397 & 0,000521 & 0,003948 & 0,198541 & 0,331033 & & 0,000207 \\
\hline t8 & 300 & 0,024385 & 0,038153 & 0,000846 & 0,001869 & 0,004354 & 0,351319 & 0,476096 & 0,174229 & 0,004182 & 0,000937 & 0,000207 & \\
\hline \multicolumn{14}{|c|}{ C - \% Quelante Tampão } \\
\hline ANOVA & $\begin{array}{l}\text { Soma dos } \\
\text { quadrados }\end{array}$ & $\begin{array}{c}\text { Grau de } \\
\text { liberdade }\end{array}$ & $\begin{array}{c}\text { Média } \\
\text { quadrada }\end{array}$ & $\mathbf{F}$ & $\mathbf{p}$ & & & & & & & & \\
\hline Intercepto & 12,11527 & 1 & 12,11527 & 958,9123 & 0,000000 & & & & & & & & \\
\hline Irradiância & 0,32831 & 1 & 0,32831 & 25,9858 & 0,000032 & & & & & & & & \\
\hline Tempo & 0,03406 & 5 & 0,00681 & 0,5392 & 0,744611 & & & & & & & & \\
\hline Irradiância*Tempo & 0,23432 & 5 & 0,04686 & 3,7092 & 0,012525 & & & & & & & & \\
\hline Erro & 0,30323 & 24 & 0,01263 & & & & & & & & & & \\
\hline \multicolumn{14}{|l|}{ Newman-Keuls } \\
\hline Tempo & Irradiância & to -60 & to -300 & $t 1-60$ & t3 -60 & t5 -60 & $t 7-60$ & t8 -60 & t1 -300 & t3 -300 & t5 -300 & t7 -300 & t8 -300 \\
\hline to & 60 & & 0,740294 & 0,931114 & 0,767807 & 0,542187 & 0,597932 & 0,021690 & 0,053653 & 0,102548 & 0,160001 & 0,663271 & 0,354111 \\
\hline to & 300 & & 0,740294 & 0,931114 & 0,767807 & 0,542187 & 0,597932 & 0,021690 & 0,053653 & 0,102548 & 0,160001 & 0,663271 & 0,354111 \\
\hline t1 & 60 & 0,740294 & & 0,980262 & 0,732640 & 0,461743 & 0,488091 & 0,011772 & 0,030418 & 0,061582 & 0,102042 & 0,720802 & 0,254533 \\
\hline $\mathrm{t} 3$ & 60 & 0,931114 & 0,980262 & & 0,826106 & 0,539002 & 0,548907 & 0,012835 & 0,033513 & 0,068611 & 0,115383 & 0,853026 & 0,288614 \\
\hline t5 & 60 & 0,767807 & 0,732640 & 0,826106 & & 0,520527 & 0,729675 & 0,069700 & 0,149461 & 0,244679 & 0,325943 & 0,800539 & 0,549842 \\
\hline t7 & 60 & 0,542187 & 0,461743 & 0,539002 & 0,520527 & & 0,913949 & 0,202133 & 0,361801 & 0,501041 & 0,581162 & 0,640702 & 0,775065 \\
\hline t8 & 60 & 0,597932 & 0,488091 & 0,548907 & 0,729675 & 0,913949 & & 0,197856 & 0,339890 & 0,448340 & 0,478904 & 0,741132 & 0,571001 \\
\hline $\mathrm{t} 1$ & 300 & 0,053653 & 0,030418 & 0,033513 & 0,149461 & 0,361801 & 0,339890 & 0,631761 & & 0,692557 & 0,746429 & 0,111146 & 0,551160 \\
\hline t3 & 300 & 0,102548 & 0,061582 & 0,068611 & 0,244679 & 0,501041 & 0,448340 & 0,654197 & 0,692557 & & 0,742146 & 0,194475 & 0,624774 \\
\hline t5 & 300 & 0,160001 & 0,102042 & 0,115383 & 0,325943 & 0,581162 & 0,478904 & 0,621253 & 0,746429 & 0,742146 & & 0,277502 & 0,553762 \\
\hline t7 & 300 & 0,663271 & 0,720802 & 0,853026 & 0,800539 & 0,640702 & 0,741132 & 0,048728 & 0,111146 & 0,194475 & 0,277502 & & 0,516517 \\
\hline t8 & 300 & 0,354111 & 0,254533 & 0,288614 & 0,549842 & 0,775065 & 0,571001 & 0,386058 & 0,551160 & 0,624774 & 0,553762 & 0,516517 & \\
\hline
\end{tabular}


Anexo III - Tabela 12. Tabelas de significância de ANOVA e teste post hoc de NewmanKeuls para porcentagem de atividade antioxidante dos extratos tamponados de pigmentos para (A) Folin-Ciocalteu e (B) FRAP.

\begin{tabular}{|c|c|c|c|c|c|c|c|c|c|c|c|c|c|}
\hline \multicolumn{14}{|l|}{ A - \% Folin Tampão } \\
\hline ANOVA & $\begin{array}{l}\text { Soma dos } \\
\text { quadrados }\end{array}$ & $\begin{array}{l}\text { Grau de } \\
\text { liberdade }\end{array}$ & $\begin{array}{l}\text { Média } \\
\text { quadrada }\end{array}$ & $\mathbf{F}$ & p & & & & & & & & \\
\hline Intercepto & 35,07406 & 1 & 35,07406 & 11927,02 & 0,000000 & & & & & & & & \\
\hline Irradiância & 0,03137 & 1 & 0,03137 & 10,67 & 0,003272 & & & & & & & & \\
\hline Tempo & 0,22586 & 5 & 0,04517 & 15,36 & 0,000001 & & & & & & & & \\
\hline Irradiância*Tempo & 0,20028 & 5 & 0,04006 & 13,62 & 0,000002 & & & & & & & & \\
\hline Erro & 0,07058 & 24 & 0,00294 & & & & & & & & & & \\
\hline \multicolumn{14}{|l|}{ Newman-Keuls } \\
\hline Tempo & Irradiância & to -60 & to -300 & $t 1-60$ & $\mathrm{t} 3-60$ & t5 - 60 & $t 7-60$ & t8 -60 & $\mathrm{t} 1-300$ & $\mathrm{t} 3-\mathbf{3 0 0}$ & t5 - 300 & t7 -300 & t8 -300 \\
\hline to & 60 & & 0,727356 & 0,798017 & 0,266841 & 0,017141 & 0,000168 & 0,466476 & 0,606247 & 0,759786 & 0,822481 & 0,447065 & 0,798390 \\
\hline to & 300 & & 0,727356 & 0,798017 & 0,266841 & 0,017141 & 0,000168 & 0,466476 & 0,606247 & 0,759786 & 0,822481 & 0,447065 & 0,798390 \\
\hline t1 & 60 & 0,727356 & & 0,943266 & 0,126688 & 0,085255 & 0,000145 & 0,406794 & 0,863004 & 0,951784 & 0,989754 & 0,829081 & 0,693692 \\
\hline t3 & 60 & 0,798017 & 7 0,943266 & & 0,138970 & 0,073205 & 0,000138 & 0,452862 & 0,933935 & 0,821724 & 0,970121 & 0,762576 & 0,885622 \\
\hline t5 & 60 & 0,266841 & 0,126688 & 0,138970 & & 0,000679 & 0,000143 & 0,400864 & 0,176101 & 0,108747 & 0,127195 & 0,031406 & 0,200188 \\
\hline t7 & 60 & 0,017141 & 0,085255 & 0,073205 & 0,000679 & & 0,000200 & 0,003649 & 0,045512 & 0,079300 & 0,046715 & 0,086801 & 0,047456 \\
\hline t8 & 60 & 0,000168 & $3 \quad 0,000145$ & 0,000138 & 0,000143 & 0,000200 & & 0,000194 & 0,000160 & 0,000126 & 0,000161 & 0,000130 & 0,000148 \\
\hline t1 & 300 & 0,606247 & 7. 0,863004 & 0,933935 & 0,176101 & 0,045512 & 0,000160 & 0,429366 & & 0,922275 & 0,959755 & 0,701539 & 0,905551 \\
\hline t3 & 300 & 0,759786 & 0,951784 & 0,821724 & 0,108747 & 0,079300 & 0,000126 & 0,394098 & 0,922275 & & 0,994496 & 0,735951 & 0,896598 \\
\hline t5 & 300 & 0,822481 & 0,989754 & 0,970121 & 0,127195 & 0,046715 & 0,000161 & 0,449263 & 0,959755 & 0,994496 & & 0,464240 & 0,953180 \\
\hline t7 & 300 & 0,447065 & 0,829081 & 0,762576 & 0,031406 & 0,086801 & 0,000130 & 0,157192 & 0,701539 & 0,735951 & 0,464240 & & 0,697529 \\
\hline t8 & 300 & 0,798390 & 0,693692 & 0,885622 & 0,200188 & 0,047456 & 0,000148 & 0,521851 & 0,905551 & 0,896598 & 0,953180 & 0,697529 & \\
\hline \multicolumn{14}{|l|}{ B - \% FRAP Tampão } \\
\hline ANOVA & $\begin{array}{l}\text { Soma dos } \\
\text { quadrados }\end{array}$ & $\begin{array}{c}\text { Grau de } \\
\text { liberdade }\end{array}$ & $\begin{array}{l}\text { Média } \\
\text { quadrada }\end{array}$ & $\mathbf{F}$ & p & & & & & & & & \\
\hline Intercepto & 290,5986 & 1 & 290,5986 & 145311,7 & 0,000000 & & & & & & & & \\
\hline Irradiância & 0,0267 & 1 & 0,0267 & 13,4 & 0,001138 & & & & & & & & \\
\hline Tempo & 0,2658 & 5 & 0,0532 & 26,6 & 0,000000 & & & & & & & & \\
\hline Irradiância*Tempo & 0,1739 & 5 & 0,0348 & 17,4 & 0,000000 & & & & & & & & \\
\hline Erro & 0,0520 & 26 & 0,0020 & & & & & & & & & & \\
\hline \multicolumn{14}{|l|}{ Newman-Keuls } \\
\hline Tempo & Irradiância & to -60 & to -300 & $t 1-60$ & $t 3-60$ & t5 - 60 & t7 -60 & t8 -60 & $\mathrm{t} 1-300$ & t3 -300 & t5 - 300 & t7 -300 & t8 - 300 \\
\hline to & 60 & & 0,000163 & 0,000188 & 0,000142 & 0,000151 & 0,002248 & 0,001810 & 0,068713 & 0,000228 & 0,000145 & 0,000202 & 0,000144 \\
\hline to & 300 & & 0,000163 & 0,000188 & 0,000142 & 0,000151 & 0,002248 & 0,001810 & 0,068713 & 0,000228 & 0,000145 & 0,000202 & 0,000144 \\
\hline $\mathrm{t} 1$ & 60 & 0,000163 & & 0,033204 & 0,002306 & 0,735343 & 0,031292 & 0,027162 & 0,000351 & 0,338431 & 0,852946 & 0,407695 & 0,935009 \\
\hline t3 & 60 & 0,000188 & 0,033204 & & 0,134281 & 0,039707 & 0,000266 & 0,000249 & 0,000162 & 0,003849 & 0,038068 & 0,004851 & 0,067883 \\
\hline t5 & 60 & 0,000142 & 0,002306 & 0,134281 & & 0,001853 & 0,000151 & 0,000163 & 0,000188 & 0,000221 & 0,001333 & 0,000243 & 0,002805 \\
\hline t7 & 60 & 0,000151 & 0,735343 & 0,039707 & 0,001853 & & 0,051671 & 0,047046 & 0,000558 & 0,414827 & 0,890424 & 0,517889 & 0,993775 \\
\hline t8 & 60 & 0,002248 & 0,031292 & 0,000266 & 0,000151 & 0,051671 & & 0,873900 & 0,097853 & 0,311029 & 0,068242 & 0,153640 & 0,038283 \\
\hline t1 & 300 & 0,068713 & 0,000351 & 0,000162 & 0,000188 & 0,000558 & 0,097853 & 0,056454 & & 0,009447 & 0,000930 & 0,006406 & 0,000478 \\
\hline t3 & 300 & 0,000228 & 0,338431 & 0,003849 & 0,000221 & 0,414827 & 0,311029 & 0,368270 & 0,009447 & & 0,279047 & 0,982694 & 0,281523 \\
\hline t5 & 300 & 0,000145 & 0,852946 & 0,038068 & 0,001333 & 0,890424 & 0,068242 & 0,072100 & 0,000930 & 0,279047 & & 0,506025 & 0,655094 \\
\hline t7 & 300 & 0,000202 & 0,407695 & 0,004851 & 0,000243 & 0,517889 & 0,153640 & 0,251139 & 0,006406 & 0,982694 & 0,506025 & & 0,407106 \\
\hline t8 & 300 & 0,000144 & 0,935009 & 0,067883 & 0,002805 & 0,993775 & 0,038283 & 0,036847 & 0,000478 & 0,281523 & 0,655094 & 0,407106 & \\
\hline
\end{tabular}


Anexo III - Tabela 13. Tabelas de significância de ANOVA e teste post hoc de NewmanKeuls para equivalente ácido gálico dos extratos tamponados de pigmentos para (A) DPPH, (B) ABTS e (C) quelante de metais.

\begin{tabular}{|c|c|c|c|c|c|c|c|c|c|c|c|c|c|}
\hline \multicolumn{14}{|c|}{ A - Eq. Ác.gálico DPPH Tampão } \\
\hline ANOVA & $\begin{array}{l}\text { Soma dos } \\
\text { quadrados }\end{array}$ & $\begin{array}{l}\text { Grau de } \\
\text { liberdade }\end{array}$ & $\begin{array}{l}\text { Média } \\
\text { quadrada }\end{array}$ & $F$ & $p$ & & & & & & & & \\
\hline Intercepto & 0,116236 & 1 & 0,116236 & 494,2029 & 0,000000 & & & & & & & & \\
\hline Irradiância & 0,000016 & 1 & 0,000016 & 0,0660 & 0,799013 & & & & & & & & \\
\hline Tempo & 0,010030 & 5 & 0,002006 & 8,5289 & 0,000036 & & & & & & & & \\
\hline Irradiância*Tempo & 0,006223 & 5 & 0,001245 & 5,2915 & 0,001255 & & & & & & & & \\
\hline Erro & 0,007291 & 31 & 0,000235 & & & & & & & & & & \\
\hline \multicolumn{14}{|l|}{ Newman-Keuls } \\
\hline Tempo & Irradiância & to -60 & to -300 & $t 1-60$ & t3- 60 & t5 - 60 & t7 - 60 & t8 -60 & $t 1-300$ & $\mathrm{t} 3-\mathbf{3 0 0}$ & t5 -300 & t7 -300 & t8 -300 \\
\hline to & 60 & & 0,959587 & 0,051812 & 0,870767 & 0,096829 & 0,001754 & 0,462431 & 0,271599 & 0,931856 & 0,932282 & 0,001542 & 0,329808 \\
\hline to & 300 & & 0,959587 & 0,051812 & 0,870767 & 0,096829 & 0,001754 & 0,462431 & 0,271599 & 0,931856 & 0,932282 & 0,001542 & 0,329808 \\
\hline t1 & 60 & 0,959587 & & 0,048109 & 0,758914 & 0,087679 & 0,001662 & 0,379707 & 0,230419 & 0,760835 & 0,989794 & 0,001470 & 0,295054 \\
\hline t3 & 60 & 0,051812 & 0,048109 & & 0,140108 & 0,716664 & 0,166964 & 0,485429 & 0,676521 & 0,077155 & 0,050345 & 0,288477 & 0,505974 \\
\hline t5 & 60 & 0,870767 & 0,758914 & 0,140108 & & 0,211615 & 0,006657 & 0,367677 & 0,340094 & 0,689243 & 0,913309 & 0,006210 & 0,492626 \\
\hline t7 & 60 & 0,096829 & 0,087679 & 0,716664 & 0,211615 & & 0,192279 & 0,587285 & 0,730125 & 0,130108 & 0,096547 & 0,247900 & 0,453638 \\
\hline t8 & 60 & 0,001754 & 0,001662 & 0,166964 & 0,006657 & 0,192279 & & 0,047984 & 0,107245 & 0,002965 & 0,001680 & 0,905096 & 0,073087 \\
\hline t1 & 300 & 0,271599 & 0,230419 & 0,676521 & 0,340094 & 0,730125 & 0,107245 & 0,612352 & & 0,278870 & 0,287802 & 0,112459 & 0,999592 \\
\hline t3 & 300 & 0,931856 & 0,760835 & 0,077155 & 0,689243 & 0,130108 & 0,002965 & 0,396050 & 0,278870 & & 0,970285 & 0,002685 & 0,374906 \\
\hline t5 & 300 & 0,932282 & 0,989794 & 0,050345 & 0,913309 & 0,096547 & 0,001680 & 0,503327 & 0,287802 & 0,970285 & & 0,001408 & 0,338290 \\
\hline t7 & 300 & 0,001542 & 0,001470 & 0,288477 & 0,006210 & 0,247900 & 0,905096 & 0,047339 & 0,112459 & 0,002685 & 0,001408 & & 0,083587 \\
\hline t8 & 300 & 0,329808 & 0,295054 & 0,505974 & 0,492626 & 0,453638 & 0,073087 & 0,865825 & 0,999592 & 0,374906 & 0,338290 & 0,083587 & \\
\hline \multicolumn{14}{|c|}{ B - Eq. Ác.gálico ABTS Tampão } \\
\hline ANOVA & $\begin{array}{l}\text { Soma dos } \\
\text { quadrados }\end{array}$ & $\begin{array}{l}\text { Grau de } \\
\text { liberdade }\end{array}$ & $\begin{array}{l}\text { Média } \\
\text { quadrada }\end{array}$ & $\mathbf{F}$ & $p$ & & & & & & & & \\
\hline Intercepto & 0,275185 & 1 & 0,275185 & 3130,575 & 0,000000 & & & & & & & & \\
\hline Irradiância & 0,000184 & 1 & 0,000184 & 2,090 & 0,158956 & & & & & & & & \\
\hline Tempo & 0,011675 & 5 & 0,002335 & 26,563 & 0,000000 & & & & & & & & \\
\hline Irradiância*Tempo & 0,001796 & 5 & 0,000359 & 4,086 & 0,006256 & & & & & & & & \\
\hline Erro & 0,002549 & 29 & 0,000088 & & & & & & & & & & \\
\hline \multicolumn{14}{|l|}{ Newman-Keuls } \\
\hline Tempo & Irradiância & to -60 & to -300 & $t 1-60$ & $t 3-60$ & t5 - 60 & t7 - 60 & t8- 60 & $\mathrm{t} 1-300$ & t3 -300 & t5 -300 & t7 -300 & t8 - 300 \\
\hline to & 60 & & 0,000219 & 0,000191 & 0,000153 & 0,000147 & 0,005754 & 0,005928 & 0,000881 & 0,000147 & 0,000165 & 0,000139 & 0,021924 \\
\hline to & 300 & & 0,000219 & 0,000191 & 0,000153 & 0,000147 & 0,005754 & 0,005928 & 0,000881 & 0,000147 & 0,000165 & 0,000139 & 0,021924 \\
\hline t1 & 60 & 0,000219 & & 0,339304 & 0,417450 & 0,314382 & 0,179604 & 0,168300 & 0,364660 & 0,491709 & 0,325316 & 0,031746 & 0,035945 \\
\hline t3 & 60 & 0,000191 & 0,339304 & & 0,874848 & 0,840381 & 0,007219 & 0,010485 & 0,076289 & 0,804060 & 0,902987 & 0,200648 & 0,000807 \\
\hline t5 & 60 & 0,000153 & 0,417450 & 0,874848 & & 0,855285 & 0,015851 & 0,021092 & 0,123401 & 0,686520 & 0,713620 & 0,292184 & 0,001797 \\
\hline t7 & 60 & 0,000147 & 0,314382 & 0,840381 & 0,855285 & & 0,031042 & 0,034898 & 0,144348 & 0,900405 & 0,802347 & 0,211945 & 0,004077 \\
\hline t8 & 60 & 0,005754 & 0,179604 & 0,007219 & 0,015851 & 0,031042 & & 0,818872 & 0,479649 & 0,032074 & 0,007991 & 0,000400 & 0,344695 \\
\hline t1 & 300 & 0,000881 & 0,364660 & 0,076289 & 0,123401 & 0,144348 & 0,479649 & 0,355248 & & 0,186342 & 0,077355 & 0,004103 & 0,167124 \\
\hline t3 & 300 & 0,000147 & 0,491709 & 0,804060 & 0,686520 & 0,900405 & 0,032074 & 0,039549 & 0,186342 & & 0,718990 & 0,204066 & 0,003943 \\
\hline t5 & 300 & 0,000165 & 0,325316 & 0,902987 & 0,713620 & 0,802347 & 0,007991 & 0,011230 & 0,077355 & 0,718990 & & 0,337790 & 0,000891 \\
\hline t7 & 300 & 0,000139 & 0,031746 & 0,200648 & 0,292184 & 0,211945 & 0,000400 & 0,000529 & 0,004103 & 0,204066 & 0,337790 & & 0,000207 \\
\hline t8 & 300 & 0,021924 & 0,035945 & 0,000807 & 0,001797 & 0,004077 & 0,344695 & 0,467331 & 0,167124 & 0,003943 & 0,000891 & 0,000207 & \\
\hline \multicolumn{14}{|l|}{ C - Eq. Ác.gálico Qu } \\
\hline ANOVA & $\begin{array}{l}\text { Soma dos } \\
\text { quadrados }\end{array}$ & $\begin{array}{l}\text { Grau de } \\
\text { liberdade }\end{array}$ & $\begin{array}{l}\text { Média } \\
\text { quadrada }\end{array}$ & $\mathbf{F}$ & $p$ & & & & & & & & \\
\hline Intercepto & 206,7291 & 1 & 206,7291 & 1477,202 & 0,000000 & & & & & & & & \\
\hline Irradiância & 3,9611 & 1 & 3,9611 & 28,305 & 0,000019 & & & & & & & & \\
\hline Tempo & 0,4364 & 5 & 0,0873 & 0,624 & 0,683218 & & & & & & & & \\
\hline Irradiância*Tempo & 2,8642 & 5 & 0,5728 & 4,093 & 0,007895 & & & & & & & & \\
\hline Erro & 3,3587 & 24 & 0,1399 & & & & & & & & & & \\
\hline \multicolumn{14}{|l|}{ Newman-Keuls } \\
\hline Tempo & Irradiância & to -60 & to -300 & $t 1-60$ & t3- 60 & t5 -60 & t7 -60 & t8 -60 & $t 1-300$ & $t 3-300$ & t5 -300 & t7 -300 & t8 -300 \\
\hline to & 60 & & 0,758150 & 0,943817 & 0,708231 & 0,520149 & 0,588355 & 0,011597 & 0,035166 & 0,077031 & 0,132947 & 0,656063 & 0,332616 \\
\hline to & 300 & & 0,758150 & 0,943817 & 0,708231 & 0,520149 & 0,588355 & 0,011597 & 0,035166 & 0,077031 & 0,132947 & 0,656063 & 0,332616 \\
\hline t1 & 60 & 0,758150 & & 0,989888 & 0,687648 & 0,454354 & 0,493020 & 0,006610 & 0,020749 & 0,047917 & 0,087772 & 0,729014 & 0,246823 \\
\hline t3 & 60 & 0,943817 & 0,989888 & & 0,793537 & 0,538654 & 0,561534 & 0,007431 & 0,023562 & 0,054931 & 0,101928 & 0,864716 & 0,285692 \\
\hline t5 & 60 & 0,708231 & 0,687648 & 0,793537 & & 0,562038 & 0,779331 & 0,048451 & 0,125353 & 0,228710 & 0,326926 & 0,732276 & 0,585282 \\
\hline t7 & 60 & 0,520149 & 0,454354 & 0,538654 & 0,562038 & & 0,930457 & 0,131230 & 0,285394 & 0,440003 & 0,543446 & 0,624352 & 0,771728 \\
\hline t8 & 60 & 0,588355 & 0,493020 & 0,561534 & 0,779331 & 0,930457 & & 0,123365 & 0,258183 & 0,379547 & 0,431667 & 0,737999 & 0,553282 \\
\hline t1 & 300 & 0,035166 & 0,020749 & 0,023562 & 0,125353 & 0,285394 & 0,258183 & 0,577925 & & 0,654916 & 0,689615 & 0,076775 & 0,461621 \\
\hline t3 & 300 & 0,077031 & 0,047917 & 0,054931 & 0,228710 & 0,440003 & 0,379547 & 0,573600 & 0,654916 & & 0,710807 & 0,153335 & 0,564203 \\
\hline t5 & 300 & 0,132947 & 0,087772 & 0,101928 & 0,326926 & 0,543446 & 0,431667 & 0,516078 & 0,689615 & 0,710807 & & 0,240147 & 0,517526 \\
\hline t7 & 300 & 0,656063 & 0,729014 & 0,864716 & 0,732276 & 0,624352 & 0,737999 & 0,027324 & 0,076775 & 0,153335 & 0,240147 & & 0,497155 \\
\hline t8 & 300 & 0,332616 & 0,246823 & 0,285692 & 0,585282 & 0,771728 & 0,553282 & 0,274069 & 0,461621 & 0,564203 & 0,517526 & 0,497155 & \\
\hline
\end{tabular}


Anexo III - Tabela 14. Tabelas de significância de ANOVA e teste post hoc de NewmanKeuls para equivalente ácido gálico dos extratos tamponados de pigmentos para (A) FolinCiocalteu e (B) FRAP.

\begin{tabular}{|c|c|c|c|c|c|c|c|c|c|c|c|c|c|}
\hline \multicolumn{14}{|c|}{ A - Eq. Ác.gálico Folin Tampão } \\
\hline ANOVA & $\begin{array}{l}\text { Soma dos } \\
\text { quadrados }\end{array}$ & $\begin{array}{l}\text { Grau de } \\
\text { liberdade }\end{array}$ & $\begin{array}{c}\text { Média } \\
\text { quadrada }\end{array}$ & $\mathbf{F}$ & $\mathbf{p}$ & & & & & & & & \\
\hline Intercepto & 5,122547 & 1 & 5,122547 & 1967,298 & 0,000000 & & & & & & & & \\
\hline Irradiância & 0,060020 & 1 & 0,060020 & 23,050 & 0,000069 & & & & & & & & \\
\hline Tempo & 0,318926 & 5 & 0,063785 & 24,497 & 0,000000 & & & & & & & & \\
\hline Irradiância*Tempo & 0,296289 & 5 & 0,059258 & 22,758 & 0,000000 & & & & & & & & \\
\hline Erro & 0,062492 & 24 & 0,002604 & & & & & & & & & & \\
\hline \multicolumn{14}{|l|}{ Newman-Keuls } \\
\hline Tempo & Irradiância & to -60 & to -300 & $t 1-60$ & $\mathrm{t} 3-60$ & t5 - 60 & t7 - 60 & t8 -60 & $\mathrm{t} 1-300$ & t3 -300 & t5 -300 & t7 -300 & t8 - 300 \\
\hline to & 60 & & 0,752905 & 0,773057 & 0,442878 & 0,008712 & 0,000168 & 0,551239 & 0,642791 & 0,834818 & 0,801667 & 0,452715 & 0,795449 \\
\hline to & 300 & & 0,752905 & 0,773057 & 0,442878 & 0,008712 & 0,000168 & 0,551239 & 0,642791 & 0,834818 & 0,801667 & 0,452715 & 0,795449 \\
\hline $\mathrm{t} 1$ & 60 & 0,752905 & & 0,871118 & 0,259242 & 0,041994 & 0,000144 & 0,511046 & 0,859251 & 0,987771 & 0,961828 & 0,811759 & 0,730550 \\
\hline t3 & 60 & 0,773057 & 0,871118 & & 0,241946 & 0,043722 & 0,000138 & 0,505261 & 0,899730 & 0,985701 & 0,919621 & 0,793352 & 0,865973 \\
\hline t5 & 60 & 0,442878 & 0,259242 & 0,241946 & & 0,000773 & 0,000143 & 0,532298 & 0,341489 & 0,253674 & 0,242018 & 0,069491 & 0,351243 \\
\hline t7 & 60 & 0,008712 & 0,041994 & 0,043722 & 0,000773 & & 0,000152 & 0,002541 & 0,021145 & 0,023414 & 0,036325 & 0,047804 & 0,025205 \\
\hline t8 & 60 & 0,000168 & 0,000144 & 0,000138 & 0,000143 & 0,000152 & & 0,000194 & 0,000160 & 0,000161 & 0,000126 & 0,000129 & 0,000147 \\
\hline $\mathrm{t} 1$ & 300 & 0,642791 & 0,859251 & 0,899730 & 0,341489 & 0,021145 & 0,000160 & 0,538689 & & 0,954052 & 0,930265 & 0,675845 & 0,860397 \\
\hline t3 & 300 & 0,834818 & 0,987771 & 0,985701 & 0,253674 & 0,023414 & 0,000161 & 0,546861 & 0,954052 & & 0,952714 & 0,454753 & 0,960030 \\
\hline $\mathrm{t} 5$ & 300 & 0,801667 & 0,961828 & 0,919621 & 0,242018 & 0,036325 & 0,000126 & 0,519242 & 0,930265 & 0,952714 & & 0,694493 & 0,926427 \\
\hline $\mathrm{t} 7$ & 300 & 0,452715 & 0,811759 & 0,793352 & 0,069491 & 0,047804 & 0,000129 & 0,204430 & 0,675845 & 0,454753 & 0,694493 & & 0,706344 \\
\hline t8 & 300 & 0,795449 & 0,730550 & 0,865973 & 0,351243 & 0,025205 & 0,000147 & 0,600872 & 0,860397 & 0,960030 & 0,926427 & 0,706344 & \\
\hline
\end{tabular}

\begin{tabular}{|c|c|c|c|c|c|c|c|c|c|c|c|c|c|}
\hline \multicolumn{14}{|c|}{ B - Eq. Ác.gálico FRAP Tampão } \\
\hline ANOVA & $\begin{array}{l}\text { Soma dos } \\
\text { quadrados }\end{array}$ & $\begin{array}{c}\text { Grau de } \\
\text { liberdade }\end{array}$ & $\begin{array}{c}\text { Média } \\
\text { quadrada }\end{array}$ & $\mathbf{F}$ & $\mathbf{p}$ & & & & & & & & \\
\hline Intercepto & 5,075390 & 1 & 5,075390 & 4862,410 & 0,000000 & & & & & & & & \\
\hline Irradiância & 0,008496 & 1 & 0,008496 & 8,139 & 0,008385 & & & & & & & & \\
\hline Tempo & 0,158110 & 5 & 0,031622 & 30,295 & 0,000000 & & & & & & & & \\
\hline Irradiância*Tempo & 0,107429 & 5 & 0,021486 & 20,584 & 0,000000 & & & & & & & & \\
\hline Erro & 0,027139 & 26 & 0,001044 & & & & & & & & & & \\
\hline \multicolumn{14}{|l|}{ Newman-Keuls } \\
\hline Tempo & Irradiância & to -60 & to -300 & $\mathrm{t} 1-60$ & $t 3-60$ & t5 - 60 & $\mathrm{t} 7-60$ & t8 -60 & $\mathbf{t 1}-300$ & t3 -300 & t5 - 300 & t7 -300 & t8 - 300 \\
\hline to & 60 & & 0,000162 & 0,000188 & 0,000142 & 0,000149 & 0,000215 & 0,000176 & 0,010790 & 0,000134 & 0,000140 & 0,000135 & 0,000143 \\
\hline to & 300 & & 0,000162 & 0,000188 & 0,000142 & 0,000149 & 0,000215 & 0,000176 & 0,010790 & 0,000134 & 0,000140 & 0,000135 & 0,000143 \\
\hline $\mathrm{t} 1$ & 60 & 0,000162 & & 0,075533 & 0,017110 & 0,753075 & 0,024964 & 0,018120 & 0,000183 & 0,338771 & 0,844045 & 0,410276 & 0,934386 \\
\hline t3 & 60 & 0,000188 & 0,075533 & & 0,275932 & 0,095541 & 0,000435 & 0,000336 & 0,000162 & 0,010193 & 0,086057 & 0,012926 & 0,148853 \\
\hline t5 & 60 & 0,000142 & 0,017110 & 0,275932 & & 0,014659 & 0,000164 & 0,000171 & 0,000188 & 0,000943 & 0,009544 & 0,001127 & 0,020811 \\
\hline $\mathrm{t} 7$ & 60 & 0,000149 & 0,753075 & 0,095541 & 0,014659 & & 0,039484 & 0,030199 & 0,000210 & 0,402171 & 0,870604 & 0,506340 & 0,973656 \\
\hline t8 & 60 & 0,000215 & 0,024964 & 0,000435 & 0,000164 & 0,039484 & & 0,815577 & 0,032222 & 0,267490 & 0,057797 & 0,128013 & 0,030822 \\
\hline $\mathrm{t} 1$ & 300 & 0,010790 & 0,000183 & 0,000162 & 0,000188 & 0,000210 & 0,032222 & 0,021376 & & 0,002044 & 0,000293 & 0,001392 & 0,000196 \\
\hline t3 & 300 & 0,000134 & 0,338771 & 0,010193 & 0,000943 & 0,402171 & 0,267490 & 0,284142 & 0,002044 & & 0,287552 & 0,985797 & 0,282572 \\
\hline t5 & 300 & 0,000140 & 0,844045 & 0,086057 & 0,009544 & 0,870604 & 0,057797 & 0,051846 & 0,000293 & 0,287552 & & 0,520190 & 0,642771 \\
\hline $\mathrm{t} 7$ & 300 & 0,000135 & 0,410276 & 0,012926 & 0,001127 & 0,506340 & 0,128013 & 0,186716 & 0,001392 & 0,985797 & 0,520190 & & 0,410587 \\
\hline t8 & 300 & 0,000143 & 0,934386 & 0,148853 & 0,020811 & 0,973656 & 0,030822 & 0,024908 & 0,000196 & 0,282572 & 0,642771 & 0,410587 & \\
\hline
\end{tabular}




\section{Anexo IV - Extração de MAAs}

Korbee (2004), utilizou as concentrações de 20\%, 50\%, 75\% e 100\% de metanol (v/v) com o objetivo de avaliar qual concentração de metanol proporciona uma melhor extração do conteúdo de MAAs nas espécies Porphyra leucosticta Thuret, Gelidium latifolium Bornet ex Hauck e Corallina elongata J. Ellis \& Solander. A extração ficou durante 2 horas em banho a $45^{\circ} \mathrm{C}$ (Tabela AIV-15).

Anexo IV - Tabela 15. Eficiência da extração de MAAs em diferentes concentrações de metanol para as espécies Porphyra leucosticta, Gelidium latifolium e Corallina (Korbee, 2004).

\begin{tabular}{|l|c|c|c|c|}
\cline { 2 - 5 } & $20 \%$ metanol & $50 \%$ metanol & $75 \%$ metanol & $100 \%$ metanol \\
\hline P. leucosticta & $6.9 \pm 0.31$ & $5.5 \pm 0.35$ & $4.9 \pm 0.42$ & $2.1 \pm 0.29$ \\
\hline G. latifolium & $2.34 \pm 0.15$ & $1.95 \pm 0.19$ & $1.51 \pm 0.21$ & $0.78 \pm 0.18$ \\
\hline C. elongata & $1.40 \pm 0.10$ & $1.15 \pm 0.12$ & $0.89 \pm 0.11$ & $0.45 \pm 0.14$ \\
\hline
\end{tabular}

A temperatura também foi analisada por Korbee (2004), foram testadas extrações conduzidas a $4^{\circ} \mathrm{C}$ e $45^{\circ} \mathrm{C}$ utilizando como solvente orgânico $20 \%$ de metanol (v/v) durante 2 horas (Tabela AIV-16).

Anexo IV - Tabela 16. Eficiência da extração de MAAs em diferentes temperaturas na concentração de metanol $20 \%$ para as espécies Porphyra leucosticta, Gelidium latifolium e Corallina (Korbee, 2004).

\begin{tabular}{c|c|c|}
\cline { 2 - 3 } & $4^{\circ} \mathrm{C}$ & $45^{\circ} \mathrm{C}$ \\
\hline P. leucosticta & $4.2 \pm 0.35$ & $6.9 \pm 0.31$ \\
\hline G. latifolium & $1.51 \pm 0.24$ & $2.34 \pm 0.15$ \\
\hline C. elongata & $0.94 \pm 0.14$ & $1.40 \pm 0.10$ \\
\hline
\end{tabular}

A terceira variável testada foi o tempo, a autora testou tempos de extração de 2 horas, 12 horas, 24 horas e 48 horas, utilizando-se $20 \%$ de metanol, a uma temperatura de $45^{\circ} \mathrm{C}$ (Tabela AIV-17). 
Anexo IV - Tabela 17. Eficiência da extração de MAAs em diferentes tempos (horas) na concentração de metanol $20 \%$ e temperatura de $45^{\circ} \mathrm{C}$ para as espécies Porphyra leucosticta, Gelidium latifolium e Corallina (Korbee, 2004).

\begin{tabular}{|c|c|c|c|c|}
\cline { 2 - 5 } \multicolumn{1}{c|}{} & 2 horas & 12 horas & 24 horas & 48 horas \\
\hline P. leucosticta & $6.9 \pm 0.31$ & $7.1 \pm 0.24$ & $6.7 \pm 0.34$ & $7.21 \pm 0.29$ \\
\hline G. latifolium & $2.34 \pm 0.15$ & $2.28 \pm 0.22$ & $2.51 \pm 0.18$ & $2.33 \pm 0.25$ \\
\hline C. elongata & $1.40 \pm 0.10$ & $1.35 \pm 0.15$ & $1.45 \pm 0.20$ & $1.39 \pm 0.18$ \\
\hline
\end{tabular}

Após analisar todas as opções acima descritas para extração, foi padronizado o método de acordo com as opções que deram melhores resultados em termos de aumento de eficiência de extração de MAAs para algas vermelhas. Dessa forma, optou-se por utilizar metanol 20\%, num banho a $45^{\circ} \mathrm{C}$ durante um período de 2 horas.

O rendimento de todos os extratos são apresnetados nas Tabelas AIV-18-19. A Tabela AIV-20 mostra os resultados das análises estatísticas segundo a ANOVA e teste post hoc de Newman-Keuls para todas as métricas apresentadas no Capítulo III. 
Anexo IV - Tabela 18. Cálculos de rendimento dos extratos de MAAs ao longo do tempo para as amostras de $60 \mu \mathrm{mol}$ fótons. $\mathrm{m}^{-2} \cdot \mathrm{s}^{-1}$.

\begin{tabular}{cccccc}
\hline Irrad. & Tratamento & Peso Epp vazio (g) & Peso seco em estufa (g) & Rendimento & MeOH (5 $\mathbf{~ m g} / \mathbf{m L})$ \\
\hline 60 & t0 & 1,1139 & 1,1266 & 12,7 & 2,54 \\
60 & t0 & 1,1086 & 1,119 & 10,4 & 2,08 \\
60 & t0 & 1,1139 & 1,1238 & 9,9 & 1,98 \\
60 & t0 & 1,1135 & 1,1244 & 10,9 & 2,18 \\
60 & t0 & 1,109 & 1,117 & 8 & 1,6 \\
60 & t1 & 1,112 & 1,1237 & 11,7 & 2,34 \\
60 & t1 & 1,1094 & 1,1174 & 8 & 1,6 \\
60 & t1 & 1,1095 & 1,1208 & 11,3 & 2,26 \\
60 & t1 & 1,1112 & 1,1215 & 10,3 & 2,06 \\
60 & t1 & 1,1119 & 1,1215 & 9,6 & 1,92 \\
60 & t3 & 1,1066 & 1,1208 & 14,2 & 2,84 \\
60 & t3 & 1,1109 & 1,1217 & 10,8 & 2,16 \\
60 & t3 & 1,1083 & 1,1208 & 12,5 & 2,5 \\
60 & t3 & 1,113 & 1,1207 & 7,7 & 1,54 \\
60 & t3 & 1,1078 & 1,1186 & 10,8 & 2,16 \\
60 & t5 & 1,109 & 1,1211 & 12,1 & 2,42 \\
60 & t5 & 1,1112 & 1,1251 & 13,9 & 2,78 \\
60 & t5 & 1,1131 & 1,1257 & 12,6 & 2,52 \\
60 & t5 & 1,1083 & 1,124 & 15,7 & 3,14 \\
60 & t5 & 1,1071 & 1,1196 & 12,5 & 2,5 \\
60 & t7 & 1,1085 & 1,1243 & 15,8 & 3,16 \\
60 & t7 & 1,1084 & 1,1228 & 14,4 & 2,88 \\
60 & t7 & 1,1116 & 1,1236 & 12 & 2,4 \\
60 & t7 & 1,1105 & 1,1248 & 14,3 & 2,86 \\
60 & t7 & 1,1108 & 1,1274 & 16,6 & 3,32 \\
60 & t8 & 1,1138 & 1,1195 & 5,7 & 1,14 \\
60 & t8 & 1,1086 & 1,1232 & 14,6 & 2,92 \\
60 & t8 & 1,1086 & 1,1246 & 16 & 3,2 \\
60 & t8 & 1,113 & 1,1218 & 8,8 & 1,76 \\
60 & t8 & 1,11 & 1,12 & 10 & 2 \\
& & & & \\
\end{tabular}


Anexo IV - Tabela 19. Cálculos de rendimento dos extratos de MAAs ao longo do tempo para as amostras de $300 \mu \mathrm{mol}$ fótons. $\mathrm{m}^{-2} \cdot \mathrm{s}^{-1}$.

\begin{tabular}{cccccc}
\hline Irrad. & Tratamento & Peso Epp vazio (g) & Peso seco em estufa (g) & Rendimento & MeOH (5 mg/mL) \\
\hline 300 & t0 & 1,1071 & 1,1241 & 17 & 3,4 \\
300 & t0 & 1,112 & 1,1242 & 12,2 & 2,44 \\
300 & t0 & 1,109 & 1,1223 & 13,3 & 2,66 \\
300 & t0 & 1,1145 & 1,1253 & 10,8 & 2,16 \\
300 & t0 & 1,1119 & 1,1272 & 15,3 & 3,06 \\
300 & t1 & 1,1108 & 1,1216 & 10,8 & 2,16 \\
300 & t1 & 1,1087 & 1,1213 & 12,6 & 2,52 \\
300 & t1 & 1,1089 & 1,122 & 13,1 & 2,62 \\
300 & t1 & 1,1091 & 1,1225 & 13,4 & 2,68 \\
300 & t1 & 1,1135 & 1,1265 & 13 & 2,6 \\
300 & t3 & 1,1117 & 1,1259 & 14,2 & 2,84 \\
300 & t3 & 1,1083 & 1,1165 & 8,2 & 1,64 \\
300 & t3 & 1,111 & 1,1244 & 13,4 & 2,68 \\
300 & t3 & 1,1104 & 1,1155 & 5,1 & 1,02 \\
300 & t3 & 1,1109 & 1,1255 & 14,6 & 2,92 \\
300 & t5 & 1,1108 & 1,1214 & 10,6 & 2,12 \\
300 & t5 & 1,1086 & 1,1233 & 14,7 & 2,94 \\
300 & t5 & 1,1118 & 1,1249 & 13,1 & 2,62 \\
300 & t5 & 1,109 & 1,12 & 11 & 2,2 \\
300 & t7 & 1,1089 & 1,1255 & 16,6 & 3,32 \\
300 & t7 & 1,1111 & 1,1274 & 16,3 & 3,26 \\
300 & t7 & 1,1087 & 1,125 & 16,3 & 3,26 \\
300 & t7 & 1,113 & 1,1278 & 14,8 & 2,96 \\
300 & t8 & 1,1128 & 1,1265 & 13,7 & 2,74 \\
300 & t8 & 1,111 & 1,1274 & 16,4 & 3,28 \\
300 & t8 & 1,1092 & 1,1234 & 14,2 & 2,84 \\
300 & t8 & 1,112 & 1,1241 & 12,1 & 2,42 \\
300 & t8 & 1,109 & 1,12 & 11 & 2,2 \\
& & & & &
\end{tabular}


Anexo IV - Tabela 20. Tabela de significância de ANOVA e teste post hoc de NewmanKeuls para a quantificação de MAAs.

\begin{tabular}{|c|c|c|c|c|c|c|c|c|c|c|c|c|c|}
\hline $\begin{array}{l}\text { MAAs } \\
\text { ANOVA }\end{array}$ & $\begin{array}{l}\text { Soma dos } \\
\text { quadrados }\end{array}$ & $\begin{array}{l}\text { Grau de } \\
\text { liberdade }\end{array}$ & $\begin{array}{c}\text { Média } \\
\text { quadrada }\end{array}$ & $\mathbf{F}$ & p & & & & & & & & \\
\hline Intercepto & 13,99196 & 1 & 13,99196 & 1798,519 & 0,000000 & & & & & & & & \\
\hline Irradiância & 0,06073 & 1 & 0,06073 & 7,807 & 0,009847 & & & & & & & & \\
\hline Tempo & 0,21313 & 5 & 0,04263 & 5,479 & 0,001540 & & & & & & & & \\
\hline Irradiância*Tempo & 0,18592 & 5 & 0,03718 & 4,780 & 0,003347 & & & & & & & & \\
\hline Erro & 0,19449 & 25 & 0,00778 & & & & & & & & & & \\
\hline \multicolumn{14}{|l|}{ Newman-Keuls } \\
\hline Tempo & Irradiância & to -60 & t0 - 300 & $t 1-60$ & t3 -60 & t5 - 60 & t7 - 60 & t8 - 60 & $t 1-300$ & t3 -300 & t5 - 300 & t7 - 300 & t8 -300 \\
\hline to & 60 & & 0,998664 & 0,939431 & 0,994684 & 0,996580 & 0,853836 & 0,780806 & 0,000858 & 0,997658 & 0,086546 & 0,998490 & 0,999175 \\
\hline to & 300 & & 0,998664 & 0,939431 & 0,994684 & 0,996580 & 0,853836 & 0,780806 & 0,000858 & 0,997658 & 0,086546 & 0,998490 & 0,999175 \\
\hline $\mathrm{t} 1$ & 60 & 0,998664 & & 0,998107 & 0,993795 & 0,993106 & 0,595604 & 0,992683 & 0,000662 & 0,989190 & 0,055280 & 0,924029 & 0,957875 \\
\hline t3 & 60 & 0,939431 & 0,998107 & & 0,988831 & 0,997782 & 0,847016 & 0,931952 & 0,000845 & 0,993366 & 0,086675 & 0,997402 & 0,998990 \\
\hline t5 & 60 & 0,994684 & 0,993795 & 0,988831 & & 0,947483 & 0,811167 & 0,983243 & 0,000933 & 0,838614 & 0,088489 & 0,991837 & 0,998571 \\
\hline t7 & 60 & 0,996580 & 0,993106 & 0,997782 & 0,947483 & & 0,796152 & 0,983562 & 0,000715 & 0,915342 & 0,072840 & 0,988037 & 0,996707 \\
\hline t8 & 60 & 0,853836 & 0,595604 & 0,847016 & 0,811167 & 0,796152 & & 0,750980 & 0,002255 & 0,785671 & 0,097189 & 0,706356 & 0,362808 \\
\hline $\mathrm{t} 1$ & 300 & 0,000858 & 0,000662 & 0,000845 & 0,000933 & 0,000715 & 0,002255 & 0,000516 & & 0,000738 & 0,045940 & 0,000734 & 0,000524 \\
\hline t3 & 300 & 0,997658 & 0,989190 & 0,993366 & 0,838614 & 0,915342 & 0,785671 & 0,989554 & 0,000738 & & 0,073955 & 0,974610 & 0,995960 \\
\hline t5 & 300 & 0,086546 & 0,055280 & 0,086675 & 0,088489 & 0,072840 & 0,097189 & 0,055092 & 0,045940 & 0,073955 & & 0,066884 & 0,035470 \\
\hline t7 & 300 & 0,998490 & 0,924029 & 0,997402 & 0,991837 & 0,988037 & 0,706356 & 0,992356 & 0,000734 & 0,974610 & 0,066884 & & 0,987781 \\
\hline t8 & 300 & 0,999175 & 0,957875 & 0,998990 & 0,998571 & 0,996707 & 0,362808 & 0,994473 & 0,000524 & 0,995960 & 0,035470 & 0,987781 & \\
\hline
\end{tabular}




\section{ANEXO V - Análises de componentes principais e correlaçóes de Pearson}

\section{Análises de componentes principais}

A influência de cada variável para os componentes 1 e 2 da PCA para o Capítulo I estão mostradas na Figura AV-1, Capítulo II (Fig. AV-2) e o conjunto de dados de todos os capítulos na Figura AV-3.

\section{Capítulo I}

A influência das variáveis do componente 1 foram responsáveis por 46,71\% das respostas do presente estudo. Observa-se que Fv/Fm, Y(II), Y(PSII) e FC foram as variáveis que mais se correlacionaram positivamente, com valores acima de 0,3. Taxa de crescimento e $\mathrm{Y}(\mathrm{NO})$ foram os parâmetros que mais se correlacionaram negativamente para o componente 1 (Fig. AV-1A). A influência das variáveis do componente 2 foram responsáveis por 22,81\% das respostas do presente estudo. A área de ETR x PAR, ETR máx e Ik foram as variáveis que mais se correlacionaram positivamente (valores acima de 0,3). Por outro lado, a clorofila $a$ foi o parâmetro com maior correlação negativa para o componente 2 (Fig. AV-1B). A junção dos componentes 1 e 2 formam a PCA e correspondem a 69,52\% das respostas globais do presente estudo, apresentadas no item Discussão do Capítulo I. 

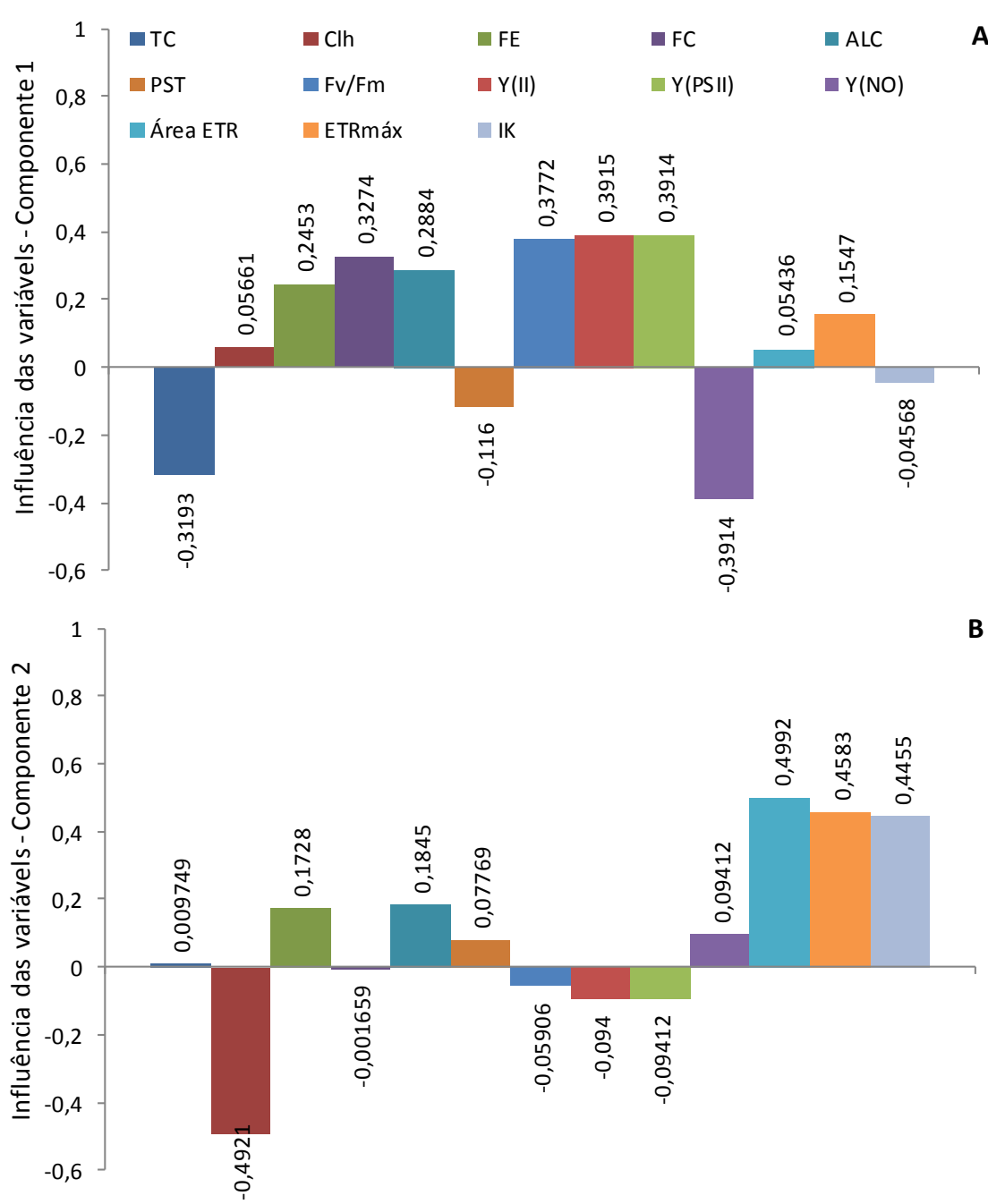

Anexo V - Figura 1. Grau de influência das variáveis do Capítulo I no componente 1 (A) e no componente 2 (B) da PCA

\section{Capítulo II}

A influência das variáveis do componente 1 foram responsáveis por $43,98 \%$ das respostas do presente estudo. Observa-se que DPPH, ABTS,e FRAP foram as variáveis que mais se correlacionaram positivamente, com valores acima de 0,4. Quelante e Folin foram os parâmetros que mais se correlacionaram negativamente para o componente 1 (Fig. AV-2A).

A influência das variáveis do componente 2 foram responsáveis por 34,94\% das respostas do presente estudo. O Folin foi a variável que teve maior correlação positiva (valores acima de 0,4). Por outro lado, a atividade quelante de metais e o FRAP contribuíram para a maior correlação negativa para o componente 2 (Fig. AV-2B).

A junção dos componentes 1 e 2, formam a PCA e correspondem a 78,92\% das respostas globais do presente estudo, apresentadas no item Discussão do Capítulo II. 

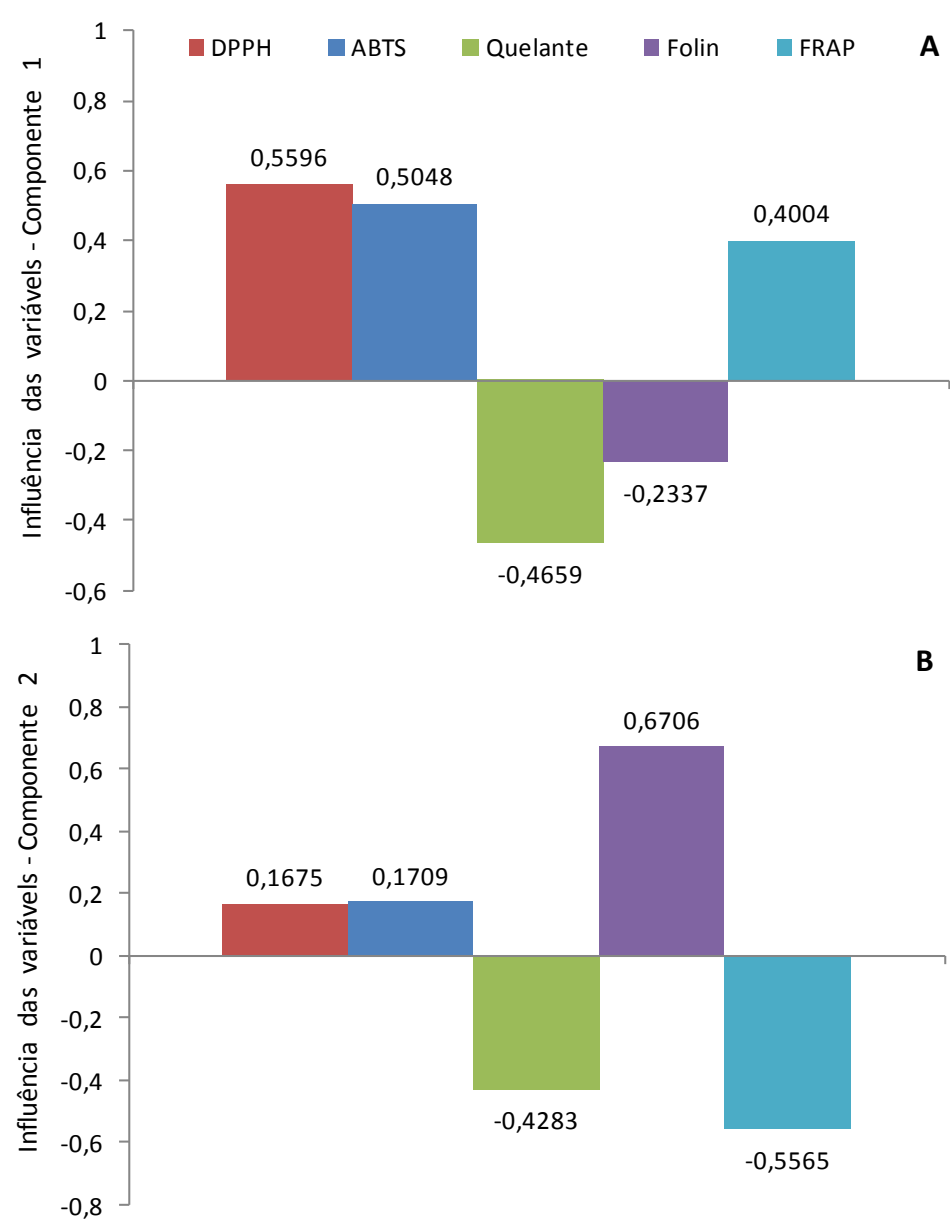

Anexo V - Figura 2. Grau de influência de cada ensaio antioxidante no componente 1 (A) e (B) no componente 2 da PCA.

\section{Capítulos I, II e III}

A influência das variáveis do componente 1 foram responsáveis por $48,14 \%$ das respostas do presente estudo. Observa-se que Fv/Fm, Y(II), Y(PSII) e FC foram as variáveis que mais se correlacionaram positivamente, com valores acima de 0,3. Y(NO) e FRAP foram os parâmetros que mais se correlacionaram negativamente para o componente 1 (Fig. AV$3 \mathrm{~A})$.

A influência das variáveis do componente 2 foram responsáveis por $23,97 \%$ das respostas do presente estudo. A área de ETR x PAR e o sequestro do radical DPPH foram as variáveis que mais se correlacionaram positivamente (valores acima de 0,3). Por outro lado, a atividade quelante de metais contribui para a maior correlação negativa para o componente 2 (Fig. AV-3B).

A junção dos componentes 1 e 2 formam a PCA e correspondem a $72 \%$ das respostas globais do presente estudo, apresentadas no item Discussão geral. 

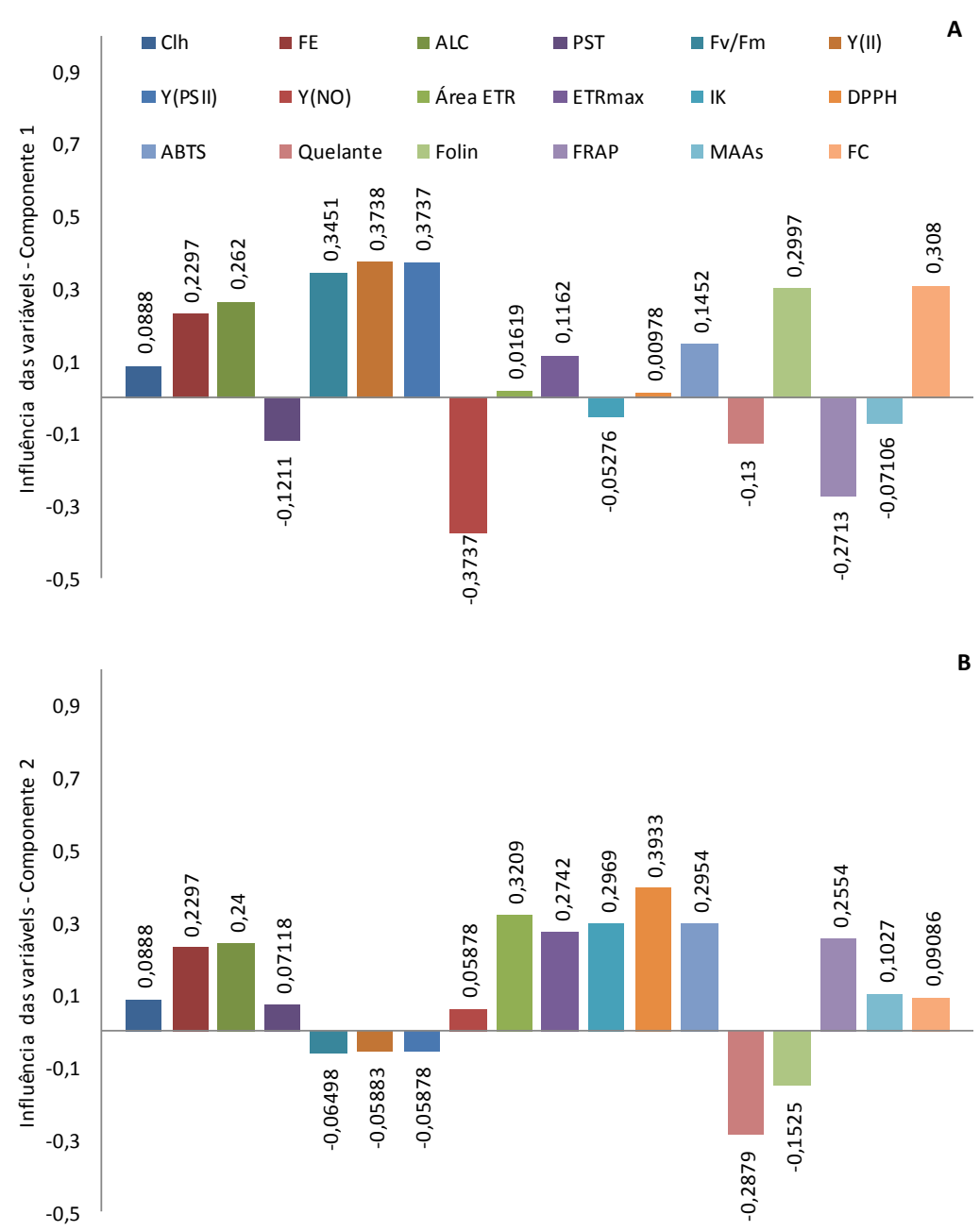

Anexo V - Figura 3. Grau de influência de cada variável no componente 1 (A) e no componente 2 (B) da PCA. TC: taxa de crescimento, Clh: clorofila $a$, FE: ficoeritrina, ALC: aloficocianina, PST: Proteínas solúveis totais, Fv/Fm: rendimento quântico ótimo, Y(II): rendimento quântico efetivo, Y(PSII): dissipação fotoquímica regulada, $\mathrm{Y}(\mathrm{NO})$ : dissipação fotoquímica não fotoquímica não regulada, Área ETR: área de ETR x PAR, Ik: saturação luninosa, MAAs: aminoácidos do tipo micosporinas, FC: ficocianina. 


\section{Correlações de Pearson}

As Tabelas AV-1, 2 e 3 apresentam os valores da correlação de Pearson para os Capítulos I, II e Discussão geral final, respectivamente. Os dados encontram-se no intervalo de -1 a 1. Ao lado direito da diagonal da linha 0 está a relação de $\mathrm{p}<0,05$ e na diagonal esquerda encontram-se os valores da correlação, nos quais, números positivos ou mais próximos a 1 mostram uma relação diretamente proporcional, ou seja, quando um parâmetro aumenta o outro segue a mesma tendência. Números negativos ou mais próximos de -1 apresentam uma relação inversamente proporcional, ou seja, quando um parâmetro aumenta o outro diminui e vice-versa. Em suma, quanto mais próximos de 1, podendo ser positivo ou negativo, os parâmetros estão mais relacionados.

Anexo V - Tabela 1. Valores da correlação de Pearson entre as variáveis da taxa de crescimento, desempenho fotossintetizante e conteúdo pigmentar, os dados estatisticamente correlacionados $(\mathrm{p}<0,05)$ estão destacados em vermelhos.

\begin{tabular}{|c|c|c|c|c|c|c|c|c|c|c|c|c|c|}
\hline & TC & Clh & $\mathrm{FE}$ & FC & ALC & PST & $\mathrm{Fv} / \mathrm{Fm}$ & $\mathrm{Y}(\mathrm{II})$ & $\mathrm{Y}$ (PSII) & $\mathrm{Y}(\mathrm{NO})$ & Área ETR & ETRmax & $\mathrm{IK}$ \\
\hline TC & 0 &, 58144 & 0,72549 & 080253 & 0,31952 & 0,12827 & 0,000452 & 0,01101 & 0,011146 & 0,011146 & 0,52261 & 0,16288 & 0,86799 \\
\hline Clh & 17731 & 0 & 14564 & 79141 & ,30193 & 6161 & 29177 & 2783 & 27819 & 27819 & 0,060467 & 0,11798 & 12325 \\
\hline FE & 0,11347 & ,44651 & 0 & 00536 & 0,0013041 & 84907 & 0,37838 & 0,1083 & 10792 & 0,10792 & 0,7875 & 0,51691 & ,95688 \\
\hline FC & $-0,52413$ & 8559 & 74574 & 0 & 0,00014552 & 0,71416 & 0,029181 & 0,023352 & 0,023506 & 0,023506 & 0,67004 & 0,82714 & 0,63889 \\
\hline ALC & $-0,31445$ & $-0,32546$ & 0,81298 & 0,8823 & 0 & 0,67093 & 0,086617 & 0,071986 & 0,072217 & 0,072217 & 0,64161 & 0,38986 & 0,79434 \\
\hline PST & 0,46439 & $-0,09812$ & $-0,061642$ & $-0,11833$ & 0,13709 & 0 & 0,63091 & 0,41653 & 0,41729 & 0,41729 & 0,98711 & 0,51418 & 0,47699 \\
\hline $\mathrm{Fv} / \mathrm{Fm}$ & $-0,85074$ & 0,33198 & 0,27983 & 0,62677 & 1503 & $-0,15482$ & 0 & 0,000049215 & 0,000050096 & 0,000050096 & 0,61601 & 0,26067 & 0,66928 \\
\hline$Y(I I)$ & $-0,7015$ & 0,34083 & 0,48703 & 0,64562 & 53673 & $-0,25887$ & 0,90602 & 0 & $3,61 E-28$ & $3,61 \mathrm{E}-28$ & 0,91333 & 0,39089 & 0,61033 \\
\hline$Y(P S I I)$ & $-0,70067$ & 4091 & 8749 & 0,64508 & 3636 & $-0,25846$ & 0,90568 & 1 & 0 & $7,87 E-50$ & ,91331 & 0,39139 & 0,60904 \\
\hline$Y(N O)$ & 0,70067 & $-0,34091$ & $-0,48749$ & $-0,64508$ & $-0,53636$ & 0,25846 & $-0,90568$ & -1 & -1 & 0 & ,91331 & 0,39139 & 0,60904 \\
\hline Área ETR & $-0,20506$ & $-0,55605$ & 0,08723 & $-0,13749$ & 0,15004 & $-0,00524$ & 0,16152 & 0,035278 & 0,035285 & $-0,035285$ & 0 & 0,00005358 & 0,035162 \\
\hline ETRmax & $-0,43006$ & $-0,47575$ & 0,20781 & 0,070711 & 0,27341 & $-0,20914$ & 0,3528 & 0,27284 & 0,27256 & $-0,27256$ & 0,90436 & 0 & 0,061088 \\
\hline IK & 0,053848 & $-0,46985$ & $-0,01753$ & $-0,15125$ & 0,084366 & 0,22751 & $-0,13782$ & $-0,16409$ & $-0,16468$ & 0,16468 & 0,61006 & 0,55495 & 0 \\
\hline
\end{tabular}

TC: taxa de crescimento, Clh: clorofila $a$, FE: ficoeritrina, FC: ficocianina, ALC: aloficocianina, PST: Proteínas solúveis totais, Fv/Fm: rendimento quântico ótimo, Y(II): rendimento quântico efetivo, Y(PSII): dissipação fotoquímica regulada, $\mathrm{Y}(\mathrm{NO})$ : dissipação fotoquímica não fotoquímica não

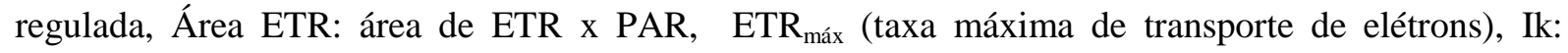
saturação luminosa.

Anexo V - Tabela 2. Valores da correlação de Pearson entre as variáveis do potencial antioxidante, os dados estatisticamente correlacionados $(\mathrm{p}<0,05)$ estão destacados em vermelhos.

\begin{tabular}{cccccc}
\hline & DPPH & ABTS & Quelante & Folin & FRAP \\
\hline DPPH & 0 & 0,11584 & 0,028612 & 0,74768 & 0,37741 \\
ABTS & 0,47819 & 0 & 0,10652 & 0,93162 & 0,41886 \\
Quelante & $-0,62848$ & $-0,48918$ & 0 & 0,49715 & 0,93421 \\
Folin & $-0,10402$ & $-0,02781$ & $-0,21748$ & 0 & 0,003235 \\
FRAP & 0,28037 & 0,25762 & $-0,02676$ & $-0,7724$ & 0
\end{tabular}


Anexo V - Tabela 3. Valores da correlação de Pearson entre todas as variáveis do presente estudo, os dados estatisticamente correlacionados $(\mathrm{p}<0,05)$ estão destacados em vermelhos.

\begin{tabular}{|c|c|c|c|c|c|c|c|c|c|c|c|c|c|c|c|c|c|c|c|}
\hline & TC & Clh & $\mathrm{FE}$ & FC & LC & ST & $\mathrm{Fv} / \mathrm{Fm}$ & (II) & $\mathrm{Y}(\mathrm{PSII})$ & $\mathrm{Y}(\mathrm{NO})$ & Área ETR & ETRmax & IK & DPPH & ABTS & Quelante & Folin & FRAP & MAAs \\
\hline TC & 0 & 58144 & 0,72549 & 080253 & 11952 & 12827 & 0,000452 & 0,01101 & 0,011146 & 0,011146 & 261 & 288 & 99 & 0,72136 & 113 & 02 & 0,04 & 0,0 & 0,0 \\
\hline Clh & ,17731, & 0 & 564 & 41 & 30193 & 61 & 77 & 83 & 19 & 19 & $0,06 c$ & 98 & 325 & 0,022556 & 46612 & 0,25937 & 586 & 66 & 0,58949 \\
\hline FE & 1347 & , 44651 & 0 & & 01304 & 07 & 38 & 83 & 92 & 992 & 7875 & 91 & 688 & 2686 & 1506 & $0,03 / 381$ & 592 & $98 /$ &,,$\angle 2034$ \\
\hline FC & 2413 & 559 & 4574 & 0 & 000146 & 1416 & 9181 & 0 , & 23506 & 23506 & 04 & 114 & 889 & 79771 & 968 & 645 & 0,069167 & 047 & 0,60783 \\
\hline ALC & 445 & 46 & 98 & 823 & 0 & 57093 & 617 & 86 & 17 & 217 & 61 & 886 & 134 & 187 & 813 & 839 & 394 & 561 & 76 \\
\hline PST & 439 & -0, & 42 & 833 & 371 & 0 & 091 & 553 & 229 & 729 & 711 & 118 & 599 & 027 & 2894 & 418 & 118 & 671 & 195 \\
\hline $\mathrm{Fv} / \mathrm{Fm}$ & 074 & 98 & & 577 & 1503 & 5482 & 0 & $4,92 \mathrm{E}-05$ & $5,01 \mathrm{E}-05$ & 05 & 501 & 67 & 28 & 999 & 365 & 18 & 625 & 668 & 0, \\
\hline$Y(I I)$ & $-0,7015$ & 0,34083 & 03 & 4562 & 0,53673 & $-0,25887$ & 0,90602 & 0 & 3,61E-28 & -28 & 1333 & 089 & 33 & 396 & 0,38097 & 95 & 527 & 369 & 142 \\
\hline$Y(P S I I)$ & $-0,70067$ & 0,34091 & 8749 & 0,64508 & 0,53636 & $-0,25846$ & 0,90568 & 1 & 0 & $7,88 \mathrm{E}-50$ & 1331 & 139 & 0,60904 & 4023 & 0,38043 & 401 & 537 & 903 & 946 \\
\hline$Y(N O)$ & 0067 & $-0,34091$ & 749 & $-0,64508$ & $-0,53636$ & 0,25846 & $-0,90568$ & -1 & -1 & 0 & 91331 & 0,39139 & 0,60904 & 74023 & 0,38043 & 401 & 5537 & 03 & 946 \\
\hline Área ETR & $-0,20506$ & $-0,55605$ & 723 & $-0,13749$ & 0,15004 & $-0,00524$ & 0,16152 & 0,035278 & 0,035285 & $-0,03529$ & 0 & $5,36 \mathrm{E}-05$ & 0,035162 &, 037647 & 0,21329 & 5832 & 398 & 011 & 3448 \\
\hline ETRmax & $-0,43006$ & $-0,47575$ & 6781 & 0,070711 & 27341 & $-0,20914$ & 3528 & 0,27284 & 27256 & $-0,27256$ & 90436 & 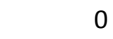 & 0,061088 & 0,076099 & 0,37487 & 0,60825 & 0898 & D205 & 0,36911 \\
\hline IK & 0,053848 & $-0,46985$ & $-0,01753$ & $-0,15125$ & 0,084366 & 0,22751 & 0,13782 & $-0,16409$ & $-0,16468$ & 0,16468 & 61006 & 0,55495 & 0 & 0,14319 & 0,51425 & 0,15386 & 51346 & 3667 & 0,67273 \\
\hline DPPH & 0,11524 & $-0,64845$ & 0,46592 & 0,082959 & 0,29504 & $-0,29015$ & $-0,21118$ & $-0,10745$ & $-0,10718$ & 0,10718 & 60372 & 0,53034 & 0,44894 & 0 & 0,11584 & 0,028612 & 0,74768 & , 377441 & 0,16349 \\
\hline ABTS & $-0,11956$ & $-0,23301$ & 9097 & 45248 & 0,70913 & 0,30869 & 0,33729 & 0,27837 & 0,27867 & $-0,27867$ & 38751 & 0,28181 & 0,20911 & 47819 & 0 & 0,10652 & D,93162 & 41886 & 0,89339 \\
\hline Quelante & 0,11796 & 0,3537 & $-0,60439$ & $-0,45578$ & $-0,48693$ & 0,18067 & $-0,02718$ & $-0,20441$ & $-0,20438$ & 0,20438 & $-0,09951$ & $-0,16504$ & $-0,43852$ & $-0,62848$ & $-0,48918$ & 0 & 0,49715 & D,93421 & 0,15221 \\
\hline Folin & $-0,57838$ & 0,50944 & 27007 & 54125 & 0,2444 & $-0,48362$ & 0,64467 & 0,73442 & 0,73433 & $-0,73433$ & $-0,22401$ & 0,078257 & $-0,20949$ & $-0,10402$ & $-0,02781$ & $-0,21748$ & 0 & ,003235 & 0,745 \\
\hline FRAP & 0,59793 & $-0,62592$ & $-0,053075$ & $-0,30776$ & $-0,04662$ & 0,61136 & $-0,62831$ & $-0,76332$ & $-0,76287$ & 0,76287 & 0,2464 & $-0,03989$ & 0,30403 & 0,28037 & 0,25762 & $-0,02676$ & $-0,7724$ & 0 & 0,57905 \\
\hline MAAs & 0,53726 & $-0,1736$ & 0,38207 & $-0,16523$ & $-0,12152$ & $-0,1223$ & $-0,50261$ & $-0,17271$ & $-0,17126$ & 0,17126 & $-0,19936$ & $-0,28508$ & $-0,13631$ & 0,4295 & 0,043431 & $-0,4401$ & $-0,10515$ & 0,17841 & \\
\hline
\end{tabular}

TC: taxa de crescimento, Clh: clorofila $a$, FE: ficoeritrina, FC: ficocianina, ALC: aloficocianina, PST: Proteínas solúveis totais, Fv/Fm: rendimento quântico ótimo, Y(II): rendimento quântico efetivo, Y(PSII): dissipação fotoquímica regulada, Y(NO): dissipação fotoquímica não fotoquímica não regulada, Área ETR: área de ETR x PAR, ETR máx (taxa máxima de transporte de elétrons), Ik: saturação luminosa, DPPH, ABTS, Quelante, Folin, FRAP e MAAs: aminoácidos do tipo micosporinas. 